\title{
(ब)
}

AUTARQUIA ASSOCIADA À UNIVERSIDADE DE SÃO PAULO

\section{OTIMIZAÇÃO E VALIDAÇÃO DE METODOLOGIA ANALÍTICA PARA DETERMINAÇÃO DE METAIS E SEMIMETAIS EM EFLUENTES LÍQUIDOS POR ESPECTROMETRIA DE EMISSÃO ÓPTICA COM PLASMA DE ARGÔNIO (ICP-OES)}

Joyce Rodrigues Marques

Dissertação apresentada como parte dos
requisitos para obtenção do Grau de
Mestre em Ciências na Área
de Tecnologia Nuclear-Materiais

Orientadora:

Profa. Dra. Marycel Elena Barboza Cotrim 
INSTITUTO DE PESQUISAS ENERGÉTICAS E NUCLEARES

Autarquia associada à Universidade de São Paulo

\title{
OTIMIZAÇÃO E VALIDAÇÃO DE METODOLOGIA ANALÍTICA PARA DETERMINAÇÃO DE METAIS E SEMIMETAIS EM EFLUENTES LÍQUIDOS POR ESPECTROMETRIA DE EMISSÃO ÓPTICA COM PLASMA DE ARGÔNIO (ICP-OES)
}

Joyce Rodrigues Marques

\author{
Dissertação apresentada como parte dos \\ requisitos para obtenção do Grau de \\ Mestre em Ciências na Área \\ de Tecnologia Nuclear - Materiais \\ Orientadora: \\ Profa. Dra. Marycel Elena Barboza Cotrim
}

Versão Corrigida

Versão Original disponível no IPEN

São Paulo

2015 
À Deus, à minha Mãe, Rodes, ao meu Pai, Placidio e ao meu Príncipe 


\section{AGRADECIMENTOS}

Primeiramente a Deus pelo dom do pensar.

À Prof. ${ }^{a}$ Dr. ${ }^{a}$ Marycel Elena Barboza Cotrim pela oportunidade, confiança e incentivo.

Ao Instituto de Pesquisas Energéticas e Nucleares (IPEN/CNEN) e ao Centro de Química e Meio Ambiente (CQMA) pela infraestrutura de trabalho disponibilizada.

Ao CNPq pelo apoio financeiro concedido (Processo de Bolsa $n^{\circ}$ 134716/2013-2).

À Dr. aㅡ Elâine Arantes Jardim e ao Dr. Hélio Akira Furusawa pela colaboração nos estudos estatísticos e discussões técnicas.

À equipe do CQMA, Elias, Martinha, Venina, Sabine, Neusa e Douglas pelo auxílio no registro de amostras, auxílio com as análises e preparo das amostras, treinamentos, festas e caronas. Em especial à Msc. Lucilena Rebelo Monteiro que me apresentou o caminho que escolhi para minha vida profissional, certamente sem ela este período não teria sido tão doce, enriquecedor e completo. $\mathrm{E}$ às minhas amigas de laboratório, Sabrina M. V. Soares, Thamiris B Stellato, Tatiane B. S. C. Silva e Mainara G. Faustino que me acompanharam e me apoiaram.

Um agradecimento especial ao meus pais, Rodes e Placidio, que fizeram graduação, mestrado, cursos e treinamentos comigo, pois cada vez que eles acordavam bem cedo para me acompanhar, me levavam e buscavam no escuro e aguentavam minha ansiedade era uma motivação a mais, afinal o meu objetivo era o título e o deles é apenas me ver feliz.

À minha família por ser tão unida e amável. 
Ao meu Príncipe por ser quem é e por me apoiar, independente das minhas escolhas.

$\mathrm{E}$ a todos aqueles que acreditaram em mim e contribuíram para a realização deste trabalho. 
Havendo um jardineiro, mais cedo ou mais tarde um jardim aparecerá. Mas havendo um jardim sem jardineiro, mais cedo ou mais tarde ele desaparecerá. [...] O que faz um jardim são os pensamentos do jardineiro.

Rubem Alves 


\title{
OTIMIZAÇÃO E VALIDAÇÃO DE METODOLOGIA ANALÍTICA PARA DETERMINAÇÃO DE METAIS E SEMIMETAIS EM EFLUENTES LÍQUIDOS POR ESPECTROMETRIA DE EMISSÃO ÓPTICA COM PLASMA DE ARGÔNIO (ICP-OES)
}

\section{JOYCE RODRIGUES MARQUES}

\begin{abstract}
RESUMO
Além da Resolução CONAMA 430/11 definir limites para o lançamento de efluentes, também define que os laboratórios que realizam análises ambientais devem ser acreditados pelo INMETRO e também devem ter sistema de controle de qualidade implantado. Para o atendimento destes requisitos legais, o presente trabalho visa otimizar, validar e implantar a metodologia analítica desenvolvida e aplicada no Centro de Química e Meio Ambiente (CQMA) do Instituto de Pesquisas Energéticas e Nucleares (IPEN/ CNEN - SP) para a quantificação dos elementos cádmio, chumbo, cobre, prata, crômio, zinco, estanho, níquel, ferro, bário, manganês e boro em amostras de efluentes líquidos por Espectrometria de Emissão Óptica com Plasma Acoplado Indutivamente (ICP-OES). Esta metodologia é utilizada para a determinação de metais e semimetais em amostras coletadas no Programa de Monitoramento Ambiental PMA-Q do IPEN. Todo o processo de validação desta dissertação foi baseado no guia Orientativo do INMETRO DOQ-CGCRE-008 Orientação sobre Validação de Métodos Analíticos. No estudo de seletividade verificou-se que a matriz não interfere nas curvas analíticas do método em estudo; a faixa de trabalho foi determinada com base nos valores máximos permitidos (VMP) pelas legislações ambientais vigentes (Resolução CONAMA 430/11, DE 8.468/76 e DE 15.425/80) e no histórico de dados do PMA-Q e todas as curvas analíticas apresentam comportamento linear na faixa de trabalho abrangida pelo método; os limites de detecção e quantificação do método atendem aos limites definidos pelas legislações ambientais vigentes e à precisão e exatidão necessárias; a precisão e exatidão apresentaram resultados satisfatórios para a finalidade do método analítico; além do método demonstrar-se robusto, embora seja necessário que o analista se atente à variação de alguns fatores no momento da realização das análises. Também foi possível realizar a estimativa de incerteza do método de modo que fosse alcançado nível de confiança de $95 \%$ dos resultados,
\end{abstract}


foram levadas em consideração todas as etapas de preparo e análise das amostras e foi possível obter incerteza global entre $4,6 \%$ e 12,23\%. Através dos resultados obtidos nos testes estatísticos e pela avaliação do analista foi possível verificar que o método desenvolvido e aplicado no CQMA é adequado para o fim pretendido. 


\title{
OPTIMIZATION AND VALIDATION OF ANALYTICAL METHODOLOGY FOR DETERMINATION OF METALS AND SEMIMETALS IN WASTEWATER BY INDUCTIVELY COUPLED PLASMA OPTICAL EMISSION SPECTROMETRY (ICP-OES)
}

\section{JOYCE RODRIGUES MARQUES}

\begin{abstract}
Beyond define limits to wastewater release, CONAMA Resolution $n^{\circ} 430 / 11$ also define that laboratories, which perform environmental analysis, have to be accredited by INMETRO and must have quality control system deployed. In order to meet this legal requirements, this work aims to optimize, validate and deploy the analytical methodology developed and applied at the Centre of Environmental Science and Technology (CQMA) at Nuclear and Energy Research Institute (IPEN/ CNEN - SP), to the determination of the elements: cadmium, lead, copper, chromium, zinc, tin, nickel, iron, barium, manganese and boron in wastewater samples by Inductively Coupled Plasma Optical Emission Spectrometry (ICP-OES).
\end{abstract}

This methodology is used to the determination of metals and semimetals in samples collected in the IPEN's Environmental Monitoring Program PMA-Q. The entire process of validation in this dissertation relied on INMETRO guide DOQ-CGCRE008 - Guidance for Validation of Analytical Methods. In the selectivity test it was possible to verify that the matrix cause no interferences in the calibration curves of the studied method; the working range determined was based on the Maximum Allowed Values (VMP) defined by the current environmental legislations (CONAMA Resolution 430/11, State Decree 8.468/76 and State Decree 15.425/80) and in the historical data from PMA-Q and all calibration curves presented linear behavior; the detection and quantification limits of this method also attend to the requirements of the current environmental legislation and to the required precision and accuracy; the precision and accuracy presented suitable results for the methodology objective; additionally, the analytical method presented satisfactory robustness, although the responsible for the test have to have attention to any instabilities in some factors. The measurement uncertainty was estimated as well, in order to obtain results with $95 \%$ of confidence, all steps of preparation and analysis of the samples were 
considered and was possible to reach global uncertainty between $4,6 \%$ and $12,23 \%$. Through the results obtained in the statistics tests and the analyst evaluation, was possible to conclude that the analytical methodology developed at CQMA is adequate to the intended purpose. 


\section{SUMÁRIO}

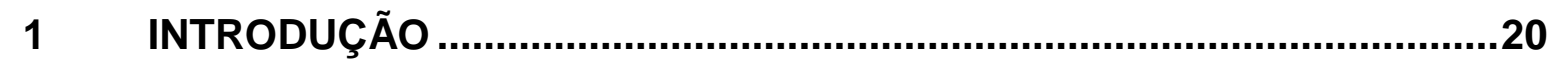

2 OBJETIVOS

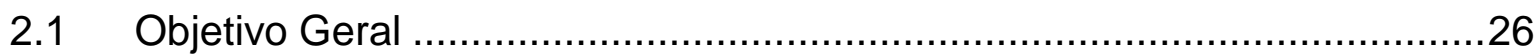

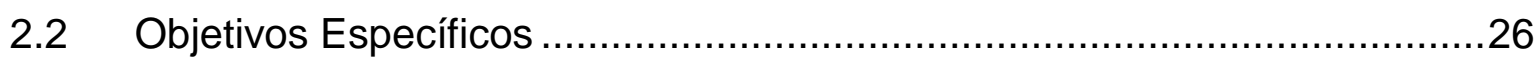

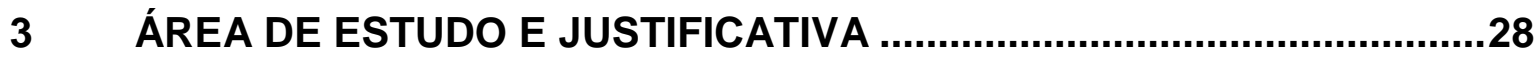

3.1 Instituto de Pesquisas Energéticas e Nucleares (IPEN) ...........................28

3.2 Justificativa: Por que validar? ............................................................

3.2.1 Programa de Monitoramento Ambiental dos Compostos Químicos Estáveis

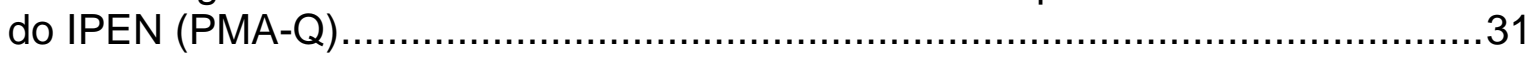

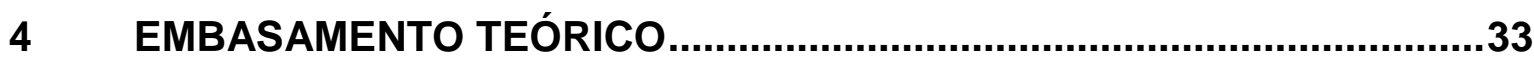

4.1 Desenvolvimento dos Valores Máximos Permitidos para os Metais ...........33

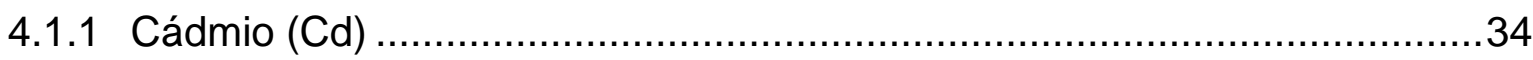

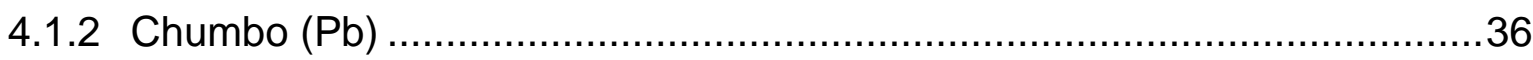

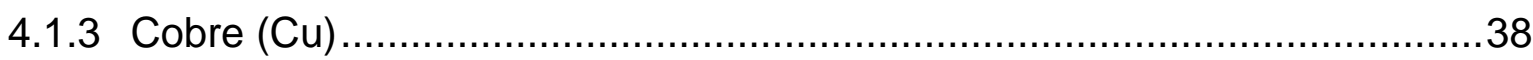

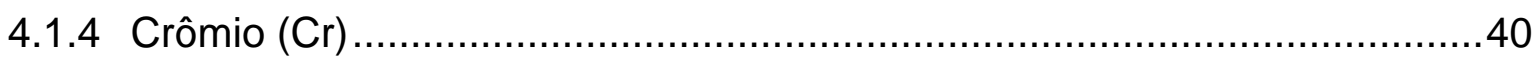

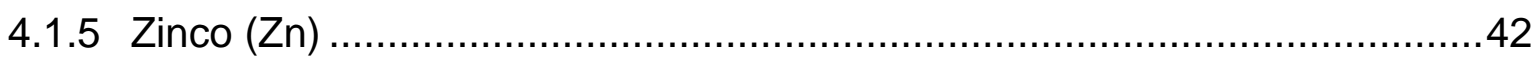

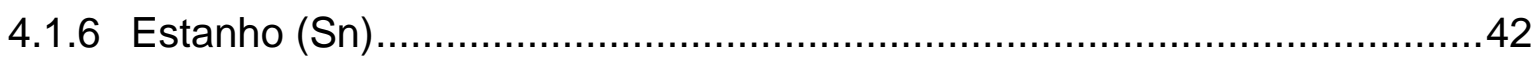

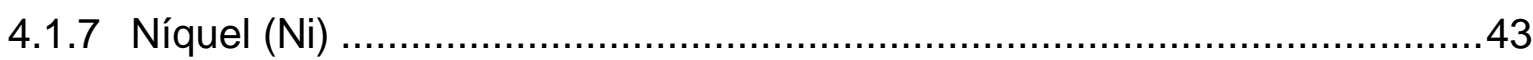

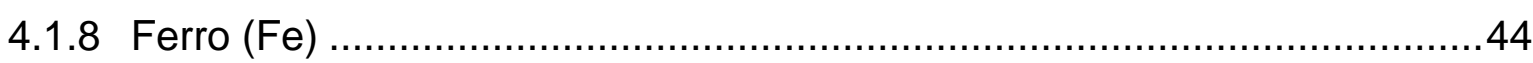

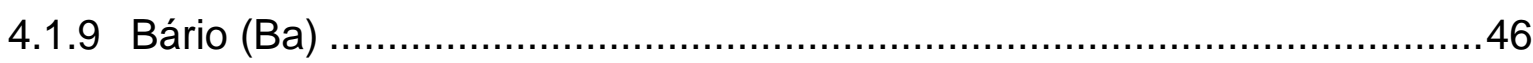

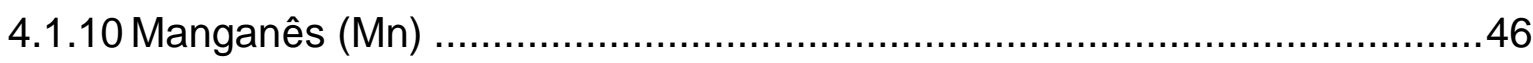

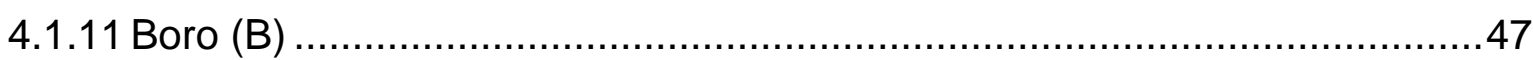

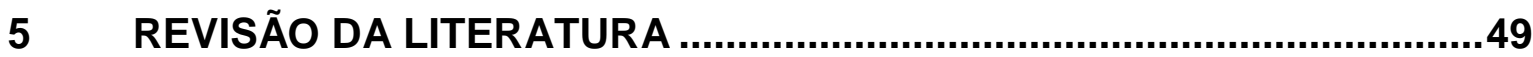

5.1 Histórico Legal quanto ao Descarte de Efluentes Líquidos Industriais .......49

5.2 Política Nacional de Recursos Hídricos: Uma Descrição da Política ..........59

5.2.1 Objetivos da Política Nacional de Recursos Hídricos .................................59

5.2.2 Atores, Arenas e Fóruns da Política Nacional de Recursos Hídricos .........60

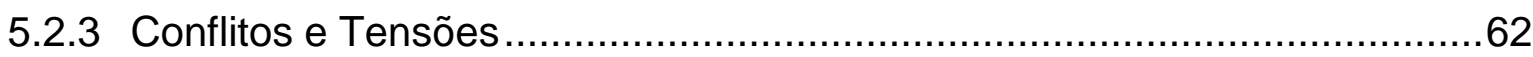

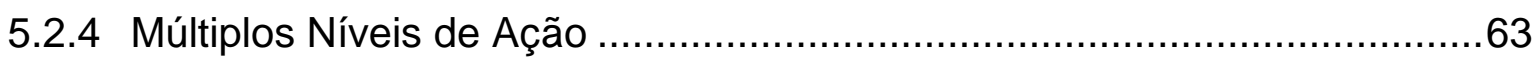

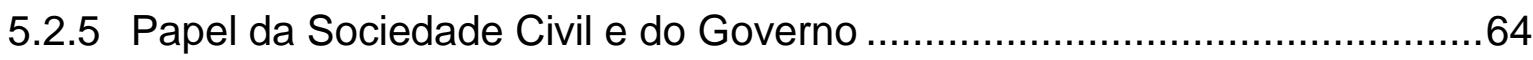

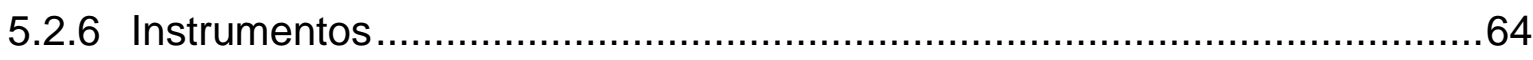

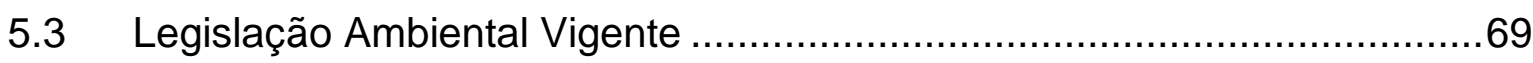

5.3.1 Legislação Federal: Resolução CONAMA 430/11 …...............................69

5.3.2 Legislação Estadual de São Paulo: D.E. 8.468 e D.E. 15425 ....................70 
6 TÉCNICA ANALÍTICA .72

6.1 Espectrometria .72

6.2 Espectrometria de Emissão Óptica com Fonte de Plasma de Acoplado Indutivamente - Plasma de Argônio (ICP-OES) 74

6.3 Emissão de Radiação Eletromagnética.................................................76

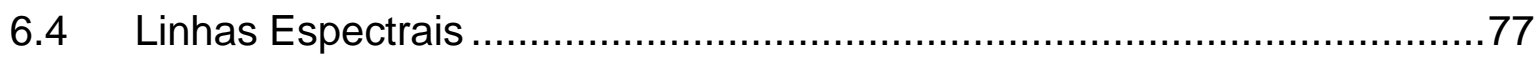

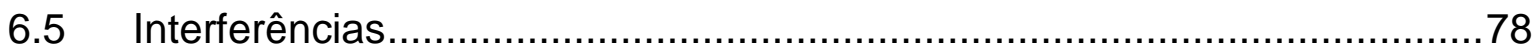

6.6 Sistemas da Técnica Espectrometria de Emissão Óptica com Fonte de

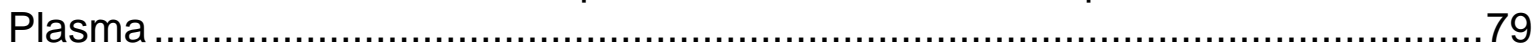

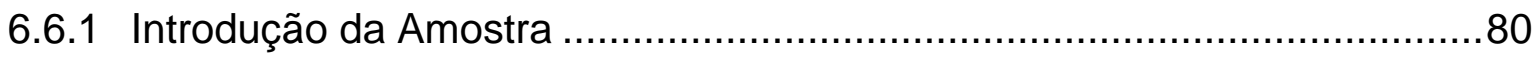

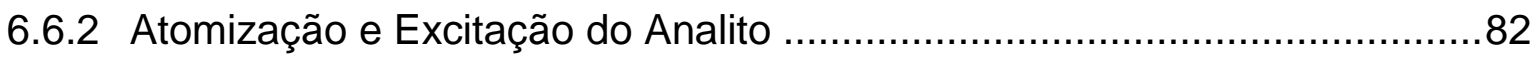

6.6.3 Plasma Acoplado Indutivamente (Plasma de Argônio) ...............................83

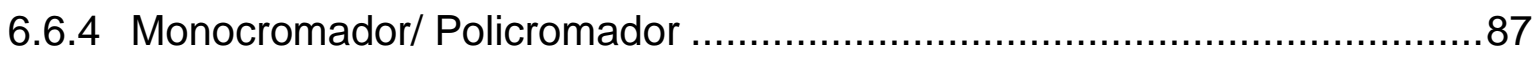

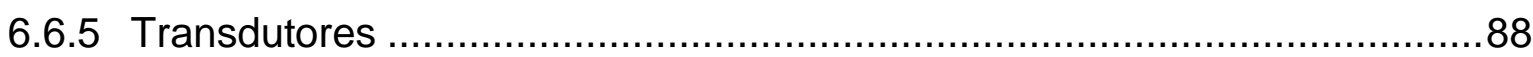

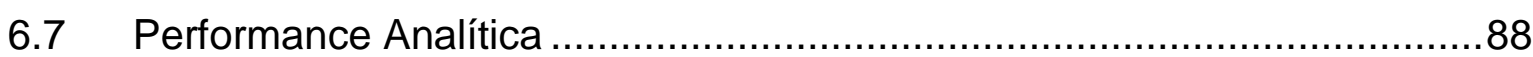

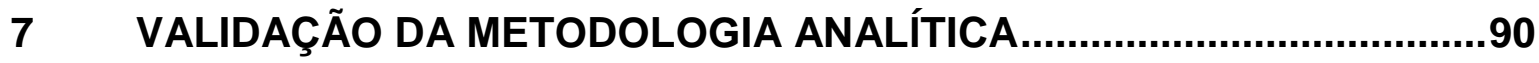

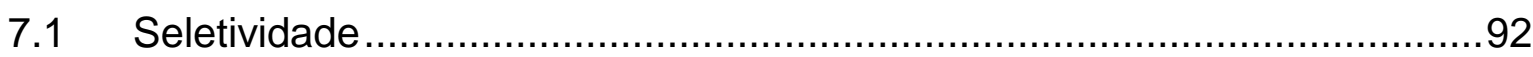

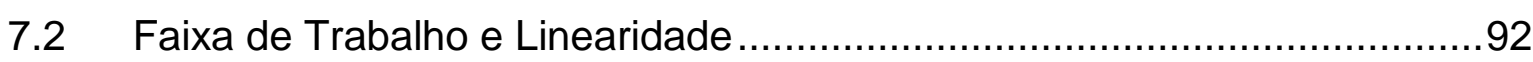

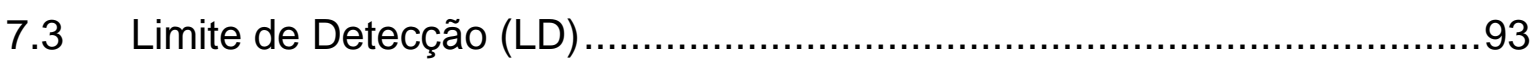

7.3.1 Limite de Quantificação (LQ) ............................................................94

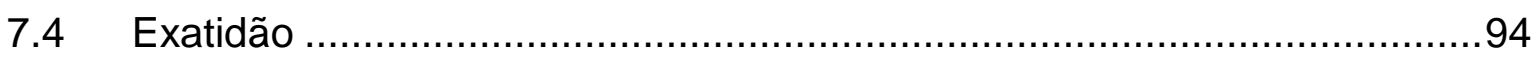

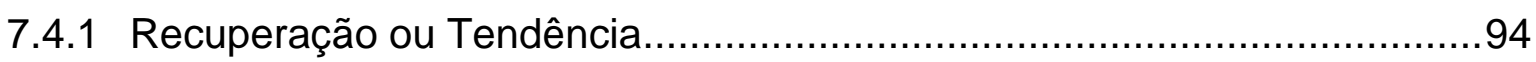

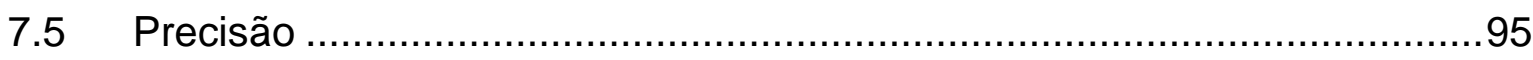

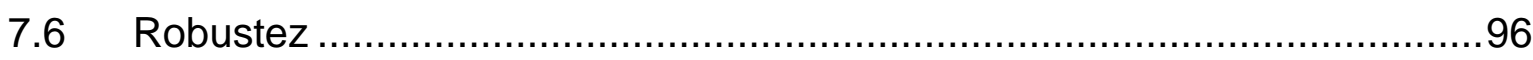

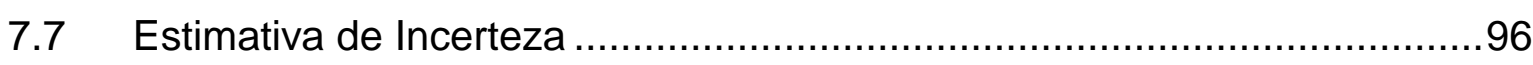

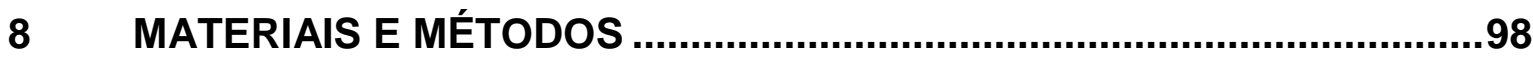

8.1 Amostragem e Preservação das Amostras ……......................................98

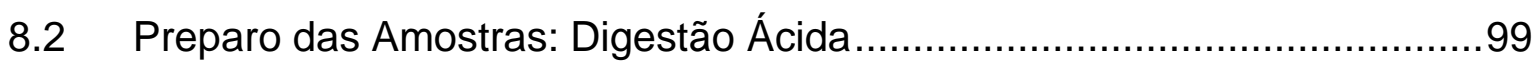

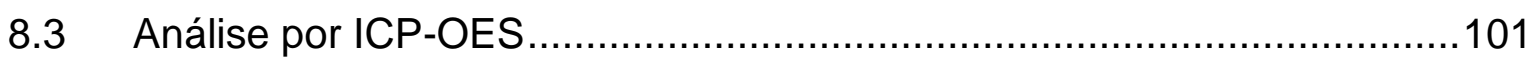

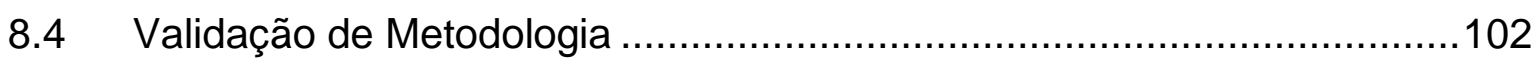

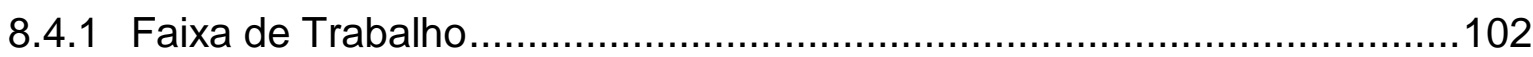

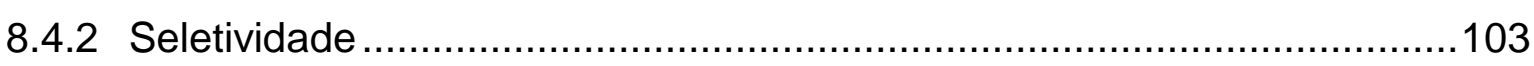

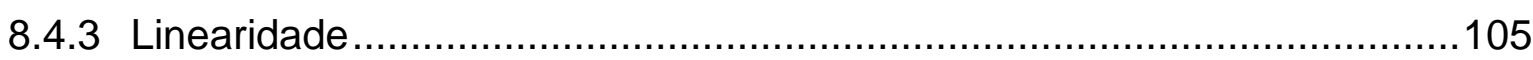

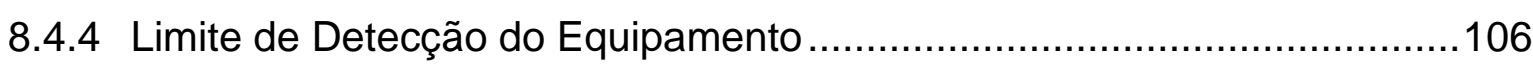

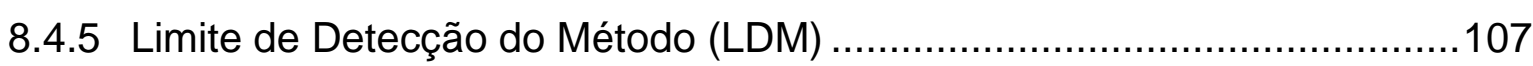

8.4.6 Limite de Quantificação do Método ......................................................107 


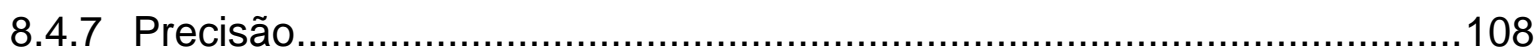

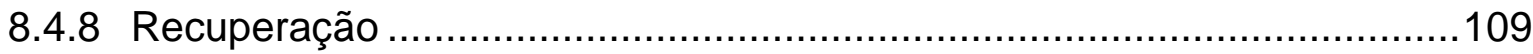

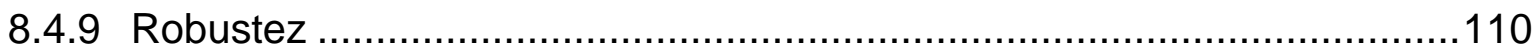

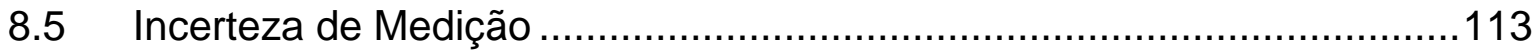

8.5.1 Determinação do Modelo Matemático ………………………..............113

8.5.2 Levantamento das Fontes de Incerteza ………..................................114

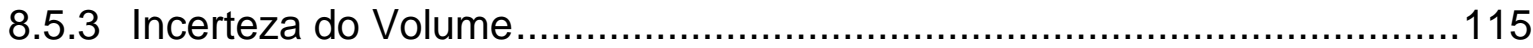

8.5.4 Incerteza do Preparo da Curva Analítica ..............................................117

8.5.5 Incerteza do Modelo da Curva Analítica .................................................119

8.5.6 Incerteza da Repetitividade do Método ...............................................119

8.5.7 Incerteza da Recuperação do Método.................................................120

8.5.8 Combinação e Expansão das Incertezas ………….............................121

9 RESULTADOS E DISCUSSÃO

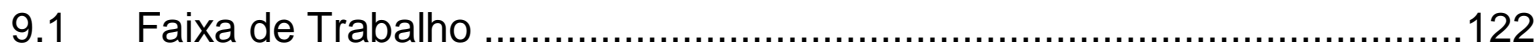

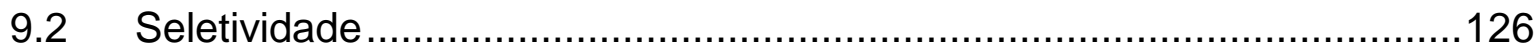

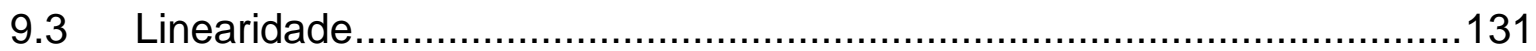

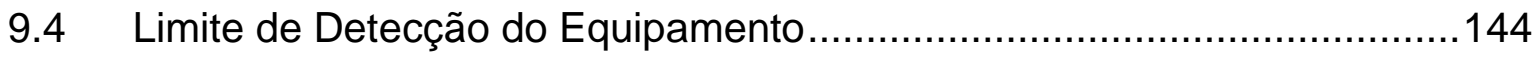

9.5 Limite de Deteç̧ão do Método ...........................................................145

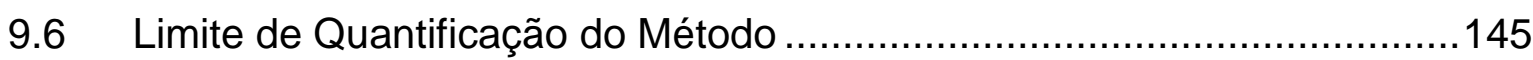

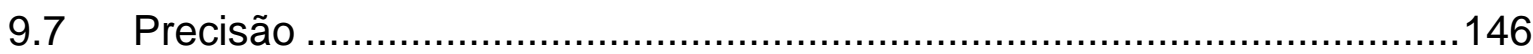

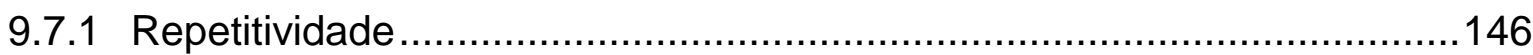

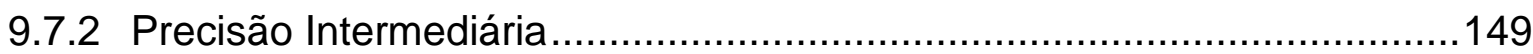

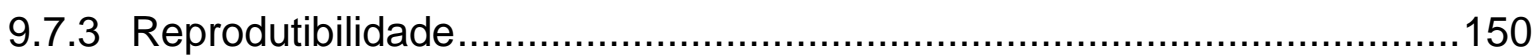

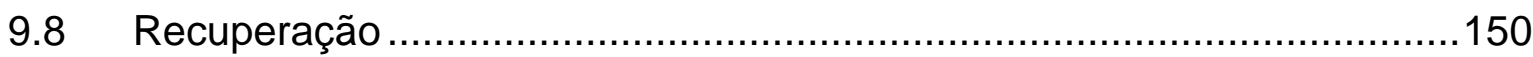

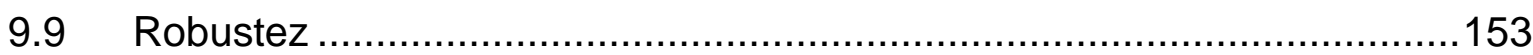

9.10 Estimativa de Incerteza de Medição.....................................................161

9.11 Aplicação da Metodologia Analítica Estudada..........................................164

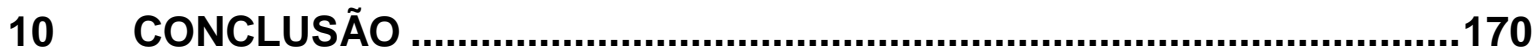

REFERÊNCIAS 


\section{LISTA DE TABELAS}

TABELA 1: VMPs dos metais e semimetais estudados, definidos na Resolução CONAMA 430/11 .70

TABELA 2: VMPs dos metais e semimetais estudados, definidos no DE 8,468/76

TABELA 3: Qualidades e limitações da técnica ICP-OES 76

TABELA 4: Parâmetros de validação conforme a natureza do ensaio. .91

TABELA 5: Programa utilizado no sistema de microondas 101

TABELA 6: Concentrações nominais adicionadas nas amostras coletadas em 2013 e 2014 110

TABELA 7: Variações selecionadas para a avaliação da robustez. 111

TABELA 8: Combinação de ensaios para a avaliação da robustez de acordo com o Teste de Youden 111

TABELA 9: Faixa de trabalho e concentração das soluções padrão multielementares para construção da curva analítica 125

TABELA 10: Linhas espectrais definidas 126

TABELA 11: Teste $F$ para sensibilidades das curvas com e sem matriz 130

TABELA 12: Teste t para desvio da linearidade 132

TABELA 13: Coeficiente de correlação das curvas segundo o software Smart Analyzer da Spectro. 132

TABELA 14: Resíduos das curvas analíticas 135

TABELA 15: Resultados da Análise de Variância 138

TABELA 16: Resultados de LDE. 144

TABELA 17: Resultados de LDM 145

TABELA 18: Resultados de LQM e DPR 146

TABELA 19: Contribuição das fontes de incerteza, concentração, incerteza combinada e incerteza expandida dos analitos. 162 


\section{LISTA DE FIGURAS}

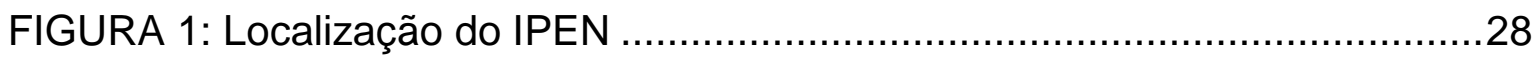

FIGURA 2: Localização da Portaria Norte do IPEN e da EME............................30

FIGURA 3: Estrutura dos colegiados do SINGREH .....................................61

FIGURA 4: Divisão de dose entre alimentação e ingestão de água ...................66

FIGURA 5: Exemplo de avaliação da conformidade de resultados.....................67

FIGURA 6: Regiões do espectro eletromagnético ........................................73

FIGURA 7: Processo de emissão de fótons....................................................77

FIGURA 8: Diagrama de blocos do equipamento de ICP-OES ..........................80

FIGURA 9: Sistema de introdução de amostra por nebulização .........................81

FIGURA 10: Nebulizador Meinhard......................................................... 82

FIGURA 11: Temperaturas em diversas regiões do plasma .............................83

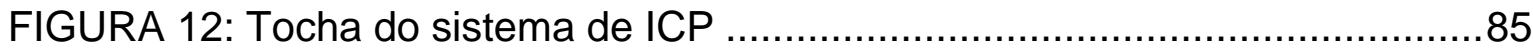

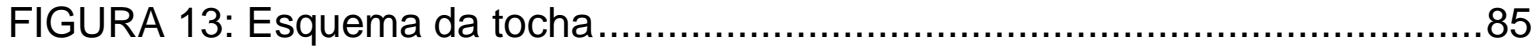

FIGURA 14: Esquema de coleta, preservação e pré-tratamento da amostra de efluente para análise

FIGURA 15: (A) Bomba peristáltica utilizada na Coleta do Efluente (B) Recipientes utilizados no processo de coleta do efluente ................................................99

FIGURA 16: Esquema simplificado do Processo de Digestão das Amostras .....100 FIGURA 17: Perfil de pressão e temperatura para a digestão das amostras .....100 FIGURA 18: Diagrama de Ishikawa para levantamento das fontes de incerteza 114 FIGURA 19: Demonstração da faixa de trabalho definida para o elemento Ba ..122 FIGURA 20: Demonstração da faixa de trabalho definida para os elementos $\mathrm{Sn}, \mathrm{Cu}$, $\mathrm{Cr}, \mathrm{Pb}, \mathrm{B}, \mathrm{Cd}$ e Fe 123

FIGURA 21: Demonstração da faixa de trabalho definida para os elementos $\mathrm{Mn}, \mathrm{Ni}$ e $\mathrm{Zn}$.

FIGURA 22: Espectros os elementos $\mathrm{Ca}, \mathrm{Fe}, \mathrm{Al}$ e $\mathrm{Na}$ nas linhas espectrais escolhidas para análise dos elementos $\mathrm{B}, \mathrm{Sn}, \mathrm{Cd}, \mathrm{Ba}, \mathrm{Cr}, \mathrm{Cu}, \mathrm{Fe}$ e $\mathrm{Mn}$. 127 FIGURA 23: Espectros os elementos $\mathrm{Ca}, \mathrm{Fe}, \mathrm{Al}$ e $\mathrm{Na}$ nas linhas espectrais escolhidas para análise dos elementos $\mathrm{Ni}, \mathrm{Pb}$ e $\mathrm{Zn}$

FIGURA 24: Curvas analíticas com matriz e sem matriz dos elementos B, Sn, Cd, $\mathrm{Ba}, \mathrm{Cr}, \mathrm{Cu}$, Fe e Mn 129 
FIGURA 25: Curvas Analíticas com matriz e sem matriz dos elementos $\mathrm{Ni}, \mathrm{Pb}$ e $\mathrm{Zn}$ 130

FIGURA 26: Distribuição dos resíduos absolutos por concentração dos elementos $\mathrm{B}, \mathrm{Sn}, \mathrm{Cd}, \mathrm{Ba}, \mathrm{Cr}$ e $\mathrm{Cu}$ 133

FIGURA 27: Distribuição dos resíduos absolutos por concentração do elemento Fe, $\mathrm{Mn}, \mathrm{Ni}, \mathrm{Pb}$ e $\mathrm{Zn}$ 134

FIGURA 28: Gráfico da variável normal padronizada dos elementos B, Sn, Cd, Ba, Cr e Cu. 136

FIGURA 29: Gráfico da variável normal padronizada dos elementos $\mathrm{Fe}, \mathrm{Mn}, \mathrm{Ni}, \mathrm{Pb}$ e $\mathrm{Zn}$.

FIGURA 30: Resultados de intervalo de confiança de 95\% para as faixas de trabalho dos elementos $\mathrm{B}$ e $\mathrm{Sn}$ 139

FIGURA 31: Resultados de intervalo de confiança de $95 \%$ para as faixas de trabalho dos elementos $\mathrm{Cd}$ e $\mathrm{Ba}$ 140

FIGURA 32: Resultados de intervalo de confiança de $95 \%$ para as faixas de trabalho dos elementos $\mathrm{Cr}$ e $\mathrm{Cu}$.

FIGURA 33: Resultados de intervalo de confiança de $95 \%$ para as faixas de trabalho dos elementos Fe e Mn. 142

FIGURA 34: Resultados de intervalo de confiança de $95 \%$ para as faixas de trabalho dos elementos $\mathrm{Ni}$ e $\mathrm{Pb}$ 143

FIGURA 35: Resultados de intervalo de confiança de $95 \%$ para as faixas de trabalho do elemento $\mathrm{Zn}$

FIGURA 36: Resultados da repetitividade obtidos com a leitura das adições nos anos de 2013 e 2014, para os elementos B, Sn, Cd, Ba, Cr e Cu

FIGURA 37: Resultados da repetitividade obtidos com a leitura das adições nos anos de 2013 e 2014, para os elementos Fe, Mn, Ni, Pb e Zn 148

FIGURA 38: Resultados da precisão intermediária obtidos com a leitura das duplicatas independentes de 2013 e 2014 149

FIGURA 39: Resultados do programa interlaboratorial da Rede Metrológica do Rio Grande do Sul para Zn e Cu 150

FIGURA 40: Resultados de recuperação obtidos com a leitura das adições em 2013 e 2014, para os elementos B, Sn, Cd, Ba, Cu e Mn

FIGURA 41: Resultados de recuperação obtidos com a leitura das adições em 2013 e 2014, para os elementos Ni, Pb e Zn. 
FIGURA 42: Resultados de recuperação obtidos com a leitura das adições em 2013 e 2014, para os elementos $\mathrm{Cr}$ e $\mathrm{Fe}$

FIGURA 43: Efeito dos parâmetros escolhidos para a avaliação da robustez do método de quantificação de $\mathrm{B}, \mathrm{Sn}, \mathrm{Cd}$ e $\mathrm{Ba}$ 154

FIGURA 44: Efeito dos parâmetros escolhidos para a avaliação da robustez do método de quantificação de $\mathrm{Cr}, \mathrm{Cu}, \mathrm{Fe}, \mathrm{Mn}, \mathrm{Ni}, \mathrm{Pb}$ e $\mathrm{Zn}$ 155

FIGURA 45: Gráficos Rankit para B, Sn, Cd, Ba Cr e Cu 157

FIGURA 46: Gráficos Rankit para Fe, Mn, Ni, Pb e Zn 158

FIGURA 47: Gráficos de probabilidade normal para B, Sn, Cd, Ba, $\mathrm{Cr}$ e Cu 159

FIGURA 48: Gráficos de probabilidade normal para $\mathrm{Fe}, \mathrm{Mn}, \mathrm{Ni}, \mathrm{Pb}$ e $\mathrm{Zn}$ 160 FIGURA 49: Contribuição das incertezas combinadas envolvidas na determinação de $\mathrm{B}, \mathrm{Sn}, \mathrm{Cd}, \mathrm{Ba}, \mathrm{Cr}$ e $\mathrm{Cu}$ 163 FIGURA 50: Contribuição das incertezas combinadas envolvidas na determinação de $\mathrm{Fe}, \mathrm{Mn}, \mathrm{Ni}, \mathrm{Pb}$ e $\mathrm{Zn}$ 164 FIGURA 51: Resultados da concentração de zinco em amostras de efluente coletadas em 2013 e 2014, com a incerteza de medição e limite da legislação.166 FIGURA 52: Resultados da concentração de ferro em amostras de efluente coletadas em 2013 e 2014, com a incerteza de medição e limite da legislação .167 FIGURA 53: Resultados da concentração de manganês em amostras de efluente coletadas em 2013 e 2014, com a incerteza de medição e limite da legislação .168 


\section{LISTA DE ABREVIATURAS}

ABNT: Associação Brasileira de Normas Técnicas

ANA: Agência Nacional de Águas

ANOVA: Análise de Variância (Analysis of Variance)

ANVISA: Agência Nacional de Vigilância Sanitária

APA: Áreas de Proteção Ambiental

ARIES: Áreas de Relevante Interesse Ecológico

ATSDR: Agência de Substâncias Tóxicas e Registro de Doenças (Agency for

Toxic Substances and Disease Registry)

B: Boro

Ba: Bário

Cd: Cádmio

CEEIBH: Comitê Especial de Estudos Integrais de Bacias Hidrográficas

CGCRE: Coordenação Geral de Acreditação do Instituto Nacional de Metrologia,

Qualidade e Tecnologia

CNEN: Comissão Nacional de Energia Nuclear

CONAMA: Conselho Nacional do Meio Ambiente

CQMA: Centro de Química e Meio Ambiente

Cr: Crômio

Cu: Cobre

DAC: Dispositivo de Acoplamento de Carga

DOQ: Documento Orientativo de Qualidade

DPR: Desvio Padrão Relativo

EIA: Estudos de Impacto Ambiental

EME: Estação de Monitoramento de Efluentes

EPA: Agência de Proteção Ambiental

Fe: Ferro

IARC: Agência Internacional de Pesquisa do Câncer (International Agency for

Research on Cancer)

ICP: Fonte de Plasma Acoplado (Inductively Coupled Plasma)

ICP-MS: Espectrometria de Massas com fonte de Plasma (Inductively Coupled

Plasma Mass Spectrometry) 
ICP-OES: Espectrometria de Emissão Óptica com Plasma Acoplado Indutivamente (Inductively Coupled Plasma Optical Emission Spectrometry) IEC: Comissão Eletrotécnica Internacional INMETRO: Instituto Nacional de Metrologia, Qualidade e Tecnologia IPCS: Programa Internacional de Segurança em Química (International Programme on Chemical Safety) IPEN: Instituto de Pesquisas Energéticas e Nucleares IRPTC: Registro Internacional de Produtos Químicos Potencialmente Tóxicos (International Register on Potentially Toxic Chemicals) ISO: Organização Internacional para Padronização (International Organization for standardization)

IUPAC: União Internacional de Química Pura e Aplicada (International Union of Pure and Applied Chemistry)

LDE: Limite de Detecção do Equipamento

LDM: Limite de Detecção do Método

LQ: Limite de Quantificação

ME: Margem de Erro

Mn: Manganês

NBR: Norma Brasileira

Ni: Níquel

NR: Norma Regulamentadora

$\mathrm{Pb}$ : Chumbo

PMA-Q: Programa de Monitoramento dos Compostos Químicos Estáveis

PMRA: Programa de Monitoração Radiológica Ambiental

PNRH: Política Nacional de Recursos Hídricos

RIMA: Relatório de Impacto Ambiental

SCTM: Comitê Científico de Toxicidade de Metais (Scientific Committee on the

Toxicology of Metals)

SE: Solução Estoque

SEMA: Secretaria Especial do Meio Ambiente

SGI: Sistema de Gestão Integrada

SINGREH: Sistema Nacional de Gerenciamento de Recursos Hídricos

SISNAMA: Sistema Nacional de Meio Ambiente

SME: Margem de Erro Simultânea 
Sn: Estanho

SNIRH: Sistema Nacional de Informações sobre Recursos Hídricos SP: São Paulo

TAC: Termo de Compromisso de Ajustamento de Conduta USP: Universidade de São Paulo

VIM: Vocabulário Internacional de Metrologia

VMP: Valores Máximos Permitidos

Zn: Zinco 
Os processos industriais podem ser definidos como uma sequência de atividades que agregam valor à uma matéria prima, e têm como objetivo produzir um bem ou serviço [1]. Estes processos são de extrema importância para a produção de produtos e materiais, mas também são os responsáveis pela geração de resíduos industriais, que de acordo com a NR 25 são resíduos provenientes dos processos industriais, na forma sólida, líquida ou gasosa ou combinação dessas, e que por suas características físicas, químicas ou microbiológicas não se assemelham aos resíduos domésticos, como cinzas, lodos, óleos, materiais alcalinos ou ácidos, substâncias lixiviadas e aqueles gerados em equipamentos e instalações de controle de poluição, bem como demais efluentes líquidos e emissões gasosas contaminantes atmosféricos [2]. Estes resíduos podem provocar grande impacto ambiental negativo quando não são geridos corretamente, sobretudo quando o meio não favorece a separação dos poluentes [3].

Por conta da água ser um bem comum e dos riscos de disseminação da contaminação, pois os poluentes reagem facilmente neste meio, formando soluções, e os recursos hídricos não possuem grandes barreiras contentoras, ou seja, mananciais superficiais e subterrâneos podem estar indiretamente interligados, o que dificulta a retirada dos poluentes e o controle do meio reacional, é de extrema importância o desenvolvimento da legislação ambiental para a proteção das águas [3].

Além dos riscos de as atividades industriais causarem uma série de impactos ambientais negativos, estas também podem causar sérios impactos negativos à saúde do ser humano - se não forem tomadas as medidas preventivas necessárias quanto ao lançamento dos efluentes industriais [4]. Nesse sentido, o 
controle governamental sobre a poluição ambiental na água e efluentes industriais, potabilidade, reuso e outros, é cada vez mais rígido e monitorado.

No Brasil, leis e decretos regulamentam os parâmetros e limites de emissão de efluentes no meio ambiente [5]. O desenvolvimento da legislação ambiental no país iniciou-se em 1923, porém com a importância do uso de água para a agricultura e a ideia de que a água era um bem inesgotável e autossustentável, a gestão de recursos hídricos e o gerenciamento de efluentes não recebiam a devida atenção, pois a preocupação com este recurso natural era vista como um atraso para o desenvolvimento da agricultura. Inevitavelmente, em 1934, na Constituição Federal o tema hídrico foi abordado pela primeira vez de forma clara, mas somente em 1960 foi promulgada a primeira lei federal que tratava da poluição das águas, e assim, o controle ambiental através de leis e decretos foi sendo desenvolvido em escala federal, estadual e municipal.

Desde 1981 é de reponsabilidade do Conselho Nacional do Meio Ambiente (CONAMA) estabelecer normas, critérios e padrões relativos ao controle e à manutenção da qualidade do meio ambiente, com vistas ao uso racional dos recursos ambientais e dos recursos hídricos [6]. A aplicação de leis e de normas no Estado de São Paulo é de responsabilidade da Companhia Ambiental do Estado de São Paulo (CETESB)"), na qualidade de órgão delegado do Governo. E o Instituto Brasileiro do Meio Ambiente e dos Recursos Naturais Renováveis (IBAMA)") tem como principais atribuições executar ações das políticas nacionais de meio ambiente, referentes às atribuições federais, relativas ao licenciamento ambiental, ao controle da qualidade ambiental, à autorização de uso dos recursos naturais e à fiscalização e monitoramento ambiental [7].

Atualmente a Resolução CONAMA 430/11 [4] (que estabelece limites para o lançamento de efluentes em corpo receptor), o Artigo 19 A do Decreto Estadual 8.468/76 [8] (que estabelece limites para o lançamento de efluentes em sistema de esgoto no Estado de São Paulo) e o Decreto Estadual 15.425/80 [9] (que altera o DE 8.468) são as normas vigentes para o controle do lançamento de efluentes no Estado de São Paulo. 
Dentre as espécies que a legislação ambiental limita a concentração na composição do efluente, encontram-se os metais, que são compostos que podem causar problemas de saúde às pessoas a curto, médio ou longo prazo, dependendo do período e intensidade da exposição ou absorção [10]. Estes também possuem potencial tóxico para animais e ao meio ambiente, desta maneira são espécies extremamente importantes no controle ambiental [11].

Assim como no Brasil, em diversos outros países existem legislações, e outros documentos que estabelecem Valores Máximos Permitidos (VMP) para a concentração dos metais e outros elementos no meio ambiente e em diversas outras matrizes. Estes VMPs começaram a ser definidos após a Segunda Guerra Mundial, primeiramente estabelecendo limites para o uso industrial de alguns compostos. Porém haviam divergências entre os VMPs, uma vez que existiam diversas listas e documentos ao redor do mundo. Somente em 1963, durante o Simpósio Internacional de Valores Máximos Permitidos foi recomendada que houvesse uma comissão internacional para a definição destes valores, e em 1968 foi recomendada a criação de um grupo específico para a análise da toxicidade de metais, o Comitê Científico para a Toxicidade de Metais, que somente foi estabelecido em Tóquio em 1969. A partir de então, iniciaram-se os estudos para a definição dos VMPs para metais em âmbito mundial [11].

O Instituto de Pesquisas Energéticas e Nucleares (IPEN) é um Instituto de Pesquisas com Instalações Nucleares e Radioativas, onde diversas atividades voltadas para o estudo e desenvolvimento das radiações e outras tecnologias são realizadas. O efluente líquido gerado no IPEN, quando resultante de processos que envolvem a manipulação de material radioativo, é retido e passa por monitoramento radiológico, se apresentar características radioativas este é segregado e destinado adequadamente. Quando não apresenta tais características o efluente é lançado na rede coletora de esgoto, juntamente com o efluente resultante dos processos que não envolvem a manipulação de material radioativo. O efluente lançado possui características domésticas e é liberado na rede coletora de esgotos sem tratamento, sendo química e fisicamente caracterizado e avaliado desde 2006, no Programa de Monitoramento dos Compostos Químicos Estáveis do IPEN (PMA-Q) de forma a assegurar que o efluente liberado atenda à legislação. 
Este programa contempla a avaliação de diversos parâmetros e define requisitos básicos para a proteção à vida e à propriedade [12], além de prover o IPEN de documentação técnica necessária para atendimento às legislações vigentes. Este programa também provê atendimento ao Termo de Compromisso de Ajustamento de Conduta (TAC) determinado pelo IBAMA, que tem por objetivo definir as obrigações a serem cumpridas pela Comissão Nacional de Energia Nuclear - CNEN/IPEN, necessárias à regularização do licenciamento ambiental de suas atividades. Estas obrigações irão consolidar a Gestão Ambiental, seguindo as diretrizes e estrutura do Sistema de Gestão Integrada (SGI) do IPEN/CNEN-SP [13].

Dentre os parâmetros avaliados no PMA-Q é realizado o monitoramento de onze metais e semimetais. Para essa avaliação é utilizada a técnica de espectrometria de emissão óptica com plasma acoplado indutivamente (ICP-OES), por ser uma técnica conceituada na determinação de elementos inorgânicos em diferentes matrizes, pois apresenta muitas vantagens quando comparada às demais técnicas espectrométricas, como eficiente ionização ou excitação, dada pelas altas temperaturas alcançadas no plasma, análise multielementar, apresenta alta sensibilidade e possibilita a análise de uma ampla faixa de concentrações por conta de sua linearidade característica $[14,15,16]$.

Esta técnica é baseada em uma emissão de fótons oriundos de íons excitados pelo plasma, que por sua vez é gerado por uma bobina de radiofrequência. A amostra é inserida no equipamento e é convertida em um aerossol, que é direcionado para o plasma, onde os átomos são transformados em íons e posteriormente são excitados, e quando estas espécies retornam para o estado fundamental, emitem fótons característicos de cada espécie química, com concentração proporcional à quantidade de fótons. Uma porção destes fótons é coletada com uma lente ou espelhos côncavos, que formam uma imagem na abertura de um equipamento de seleção de comprimentos de onda. Estes comprimentos de onda são convertidos em sinais elétricos por um fotodetector, e em um computador o sinal é amplificado e processado, gerando respostas em concentração para cada um dos analitos [15]. 
Para que a determinação das concentrações do efluente em questão seja realizada de forma confiável e os resultados que compõem o relatório anual do PMA-Q possam estar bem embasados, além de prover confiabilidade aos resultados e ao método analítico, demonstrar que o método está sob controle do analista, e também atender à Resolução CONAMA 430/11, que define em seu Art. 26 que os ensaios para a gestão de efluentes deverão ser realizados por laboratórios acreditados pelo Instituto Nacional de Metrologia, Qualidade e Tecnologia (INMETRO), a metodologia analítica para a determinação destas concentrações deve ser validada e o laboratório responsável por estas análises deve possuir controle de qualidade implementado [4].

Para a acreditação de laboratórios de ensaio junto ao INMETRO é necessário seguir as diretrizes da Norma ABNT NBR ISO/IEC 17025. Que solicita em seu capítulo 5 que o método de análises utilizado deve ser validado, e indica os documentos orientativos do INMETRO, como o DOQ-CGCRE 008, para que os requisitos de acreditação sejam atendidos [17].

A validação é utilizada para demonstrar que um método é adequado para o uso pretendido, para esta validação alguns parâmetros do método analítico são estudados, são eles: faixa de trabalho, seletividade, linearidade, limite de detecção do equipamento, limite de detecção do método, limite de quantificação do método, precisão, exatidão e robustez. Estes parâmetros demonstram as condições do método de análise.

Portanto este trabalho visa otimizar a metodologia já utilizada no PMA$Q$, validar a mesma de acordo as orientações do DOQ-CGCRE 008 do INMETRO [18] e implantar a metodologia de análise de metais e semimetais em efluente líquido por ICP-OES, para demonstrar que esta é adequada para este uso, bem como estimar a incerteza do método. A incerteza será estimada a partir do levantamento das fontes que contribuem para a incerteza final do mensurando. Foram considerados neste levantamento todas as etapas do método de preparo e análise da amostra, como o processo de digestão e diluição das amostras, modelo da curva analítica, preparo da curva analítica, recuperação do método e etc. A incerteza de medição é utilizada para demonstrar a dispersão dos resultados 
obtidos [19]. Também serão formalizadas todas as etapas da metodologia de análise e do procedimento de validação, e com estas informações obter um panorama do enquadramento deste efluente, comparando-o com a legislação ambiental vigente. 


\section{OBJETIVOS}

\subsection{Objetivo Geral}

O objetivo desse trabalho é otimizar, validar e implantar a metodologia de análise, desenvolvida e aplicada no Centro de Química e Meio Ambiente (CQMA), dos elementos químicos cádmio, chumbo, cobre, prata, crômio, zinco, estanho, níquel, ferro, bário, manganês e boro em amostras de efluentes utilizando a técnica espectrometria de emissão óptica com plasma de acoplado indutivamente - plasma de argônio (ICP-OES).

\subsection{Objetivos Específicos}

- Validar a metodologia analítica para determinação de metais e semimetais por espectrometria de emissão ótica com plasma acoplado indutivamente, avaliando os parâmetros determinados pelo INMETRO: seletividade, linearidade e faixa de trabalho, limites de detecção, limites de quantificação, exatidão, precisão e robustez, de acordo com o DOQ-CGCRE-008 do INMETRO;

- Estimar a incerteza de medição para cada elemento nas condições do método e na matriz de estudo;

- Coletar, atualizar e avaliar informações técnicas e científicas disponíveis relacionadas ao comportamento dos elementos $\mathrm{Cd}, \mathrm{Pb}$, $\mathrm{Cu}, \mathrm{Ag}, \mathrm{Cr}, \mathrm{Zn}, \mathrm{Sn}, \mathrm{Ni}, \mathrm{Fe}, \mathrm{Ba}, \mathrm{Mn}$ e B em amostras ambientais;

- Avaliar o enquadramento de cada metal analisado no efluente do IPEN conforme Resolução CONAMA 430/11, Artigo 19A do Decreto Estadual 8.468/76 e Decreto Estadual 15425/80. 


\subsection{Instituto de Pesquisas Energéticas e Nucleares (IPEN)}

A área de estudo, onde são coletadas e analisadas as amostras de efluente industrial utilizadas para a realização deste trabalho, é o campus do IPEN, situado na Cidade Universitária na Região Metropolitana da cidade de São Paulo, conforme apresentado na FIG. 1.

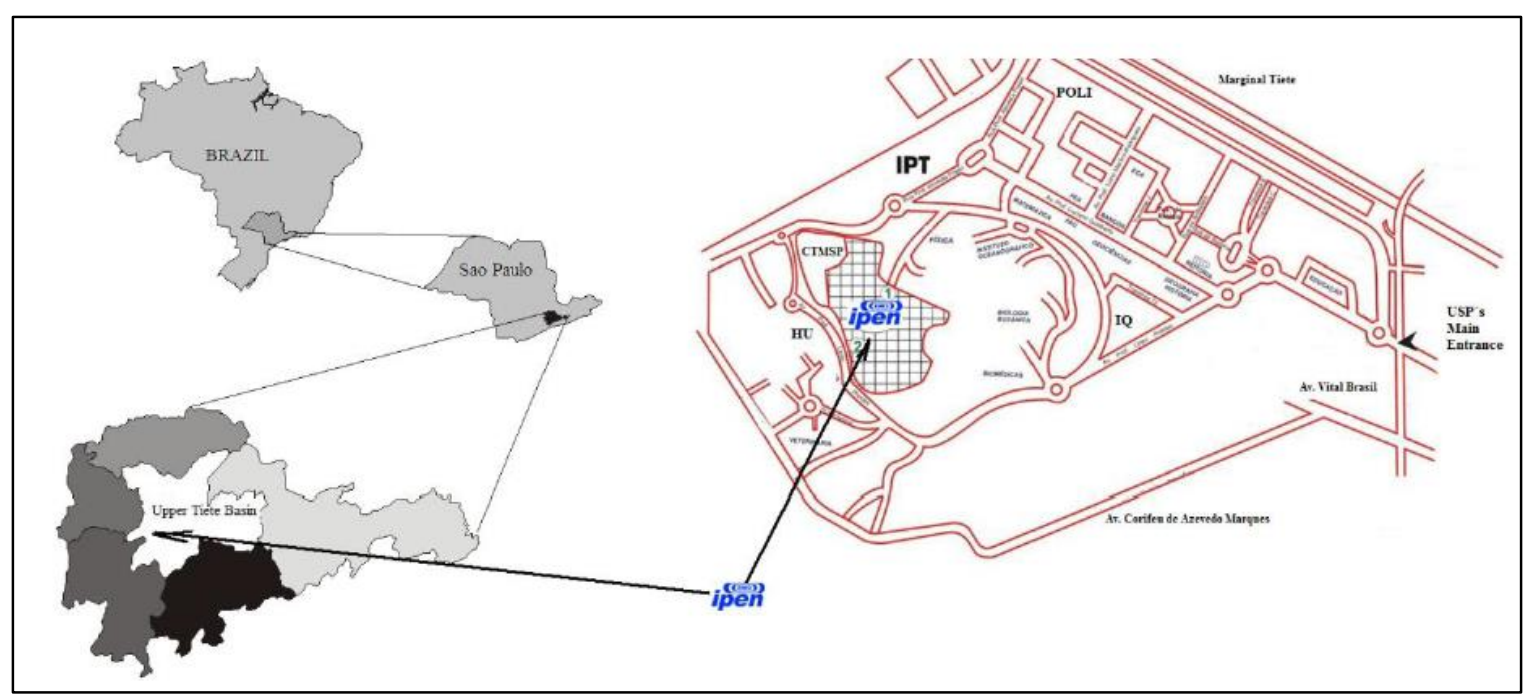

FIGURA 1: Localização do IPEN

Fonte: IPEN/CNEN-SP, 2011 [12]

O IPEN é um instituto de pesquisas composto por diferentes centros classificados como áreas nucleares ou radioativas, onde diversas atividades são realizadas, desde pesquisa e produção de material radioativo até análises com materiais químicos para finalidades distintas. Estima-se que cerca de 3000 pessoas circulam pelo instituto por dia, considerando visitantes, alunos, funcionários terceirizados e servidores, o IPEN possui $100000 \mathrm{~m}^{2}$ de área construída em uma área total de $500000 \mathrm{~m}^{2}$ [20]. 
O instituto foi fundado em 1956, é uma autarquia estadual gerida pela Comissão Nacional de Energia Nuclear (CNEN) e é associada à Universidade de São Paulo (USP) para fins de pós-graduação (mestrado, doutorado e mestrado profissional) [20].

Além de toda a estrutura laboratorial distribuída pelos seus centros, o IPEN também possui dois reatores nucleares em operação no seu campus, para fins de pesquisa. $O$ instituto se destaca pela sua atuação em vários setores da atividade nuclear (nas aplicações das radiações e radioisótopos, em desenvolvimento dos reatores nucleares, em materiais e no ciclo do combustível, em radioproteção e dosimetria) gerando resultados significativos no domínio de tecnologias, na produção de materiais e na prestação de serviços de valor econômico e estratégico. Os estudos sobre energia nuclear realizados no IPEN também possibilitam que os benefícios desta tecnologia possam ser aplicados e atendam às necessidades da população. O IPEN também se destaca pelos diversos outros estudos que não envolvem a tecnologia nuclear, como o desenvolvimento de polímeros, materiais e tecnologias ambientais [20].

Para garantir que as atividades do IPEN não estejam impactando negativamente no meio ambiente ao seu entorno, é realizado o Programa de Monitoramento Ambiental de Compostos Químicos Estáveis (PMA-Q), em complemento ao Programa de Monitoração Radiológica Ambiental (PMRA) do instituto. No PMA-Q é realizado o monitoramento de água subterrânea e efluente industrial, e é de responsabilidade do CQMA garantir a confiabilidade dos resultados gerados neste programa, conforme Termo de Ajustamento de Conduta firmado entre a CNEN e o IBAMA [13].

O efluente utilizado para a realização das análises do PMA-Q, e também para a realização deste trabalho, é coletado na Estação de Monitoramento de Efluentes (EME), localizada próximo à portaria norte do IPEN (coordenadas geográficas $23^{\circ} 33^{\prime} 43.48^{\prime \prime S}$ e $46^{\circ} 44^{\prime} 11.71$ "W - FIG. 2). 


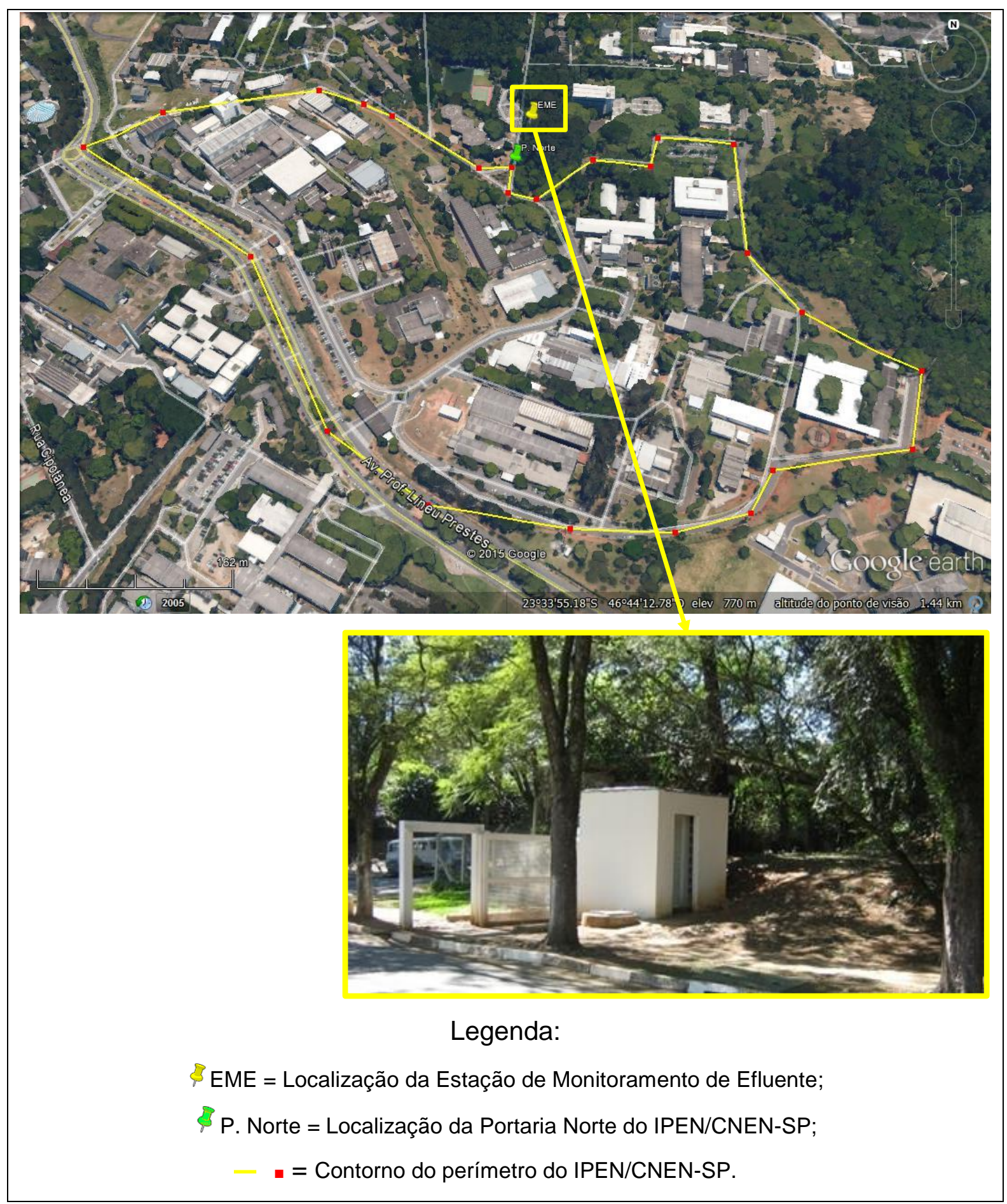

FIGURA 2: Localização da Portaria Norte do IPEN e da EME

Fonte: IPEN/CNEN-SP, 2011 [12]

\subsection{Justificativa: Por que validar?}

Validar a metodologia analítica utilizada para a realização das análises de metais e semimetais presentes no efluente lançado pelo IPEN é importante não só pela responsabilidade de garantir a conformidade com a legislação ambiental 
vigente, pois conforme a Resolução CONAMA 430/11 é mandatório que as metodologias utilizadas para a realização das análises ambientais sejam acreditadas pelo INMETRO ou órgão competente, mas também para garantir que não haja prejuízos para o meio ambiente e população do entorno do instituto, afinal com o processo de validação é possível demonstrar que a metodologia utilizada no CQMA/IPEN gera resultados confiáveis e reprodutíveis, e pode ser seguramente aplicada.

O CQMA é o centro responsável pela gestão do PMA-Q, portanto também é de sua responsabilidade garantir que os resultados que compõem o Relatório do PMA-Q sejam confiáveis e representem as condições do efluente lançado na rede coletora de esgoto. Conforme o mesmo relatório, é de competência do CQMA executar o PMA-Q de modo que os resultados atendam às normas ambientais pertinentes, envolvendo assim o desenvolvimento, implantação e validação das metodologias utilizadas para tratamento, preparo e análise das amostras [12].

Também deve ser levado em consideração o atendimento ao Termo de Compromisso de Ajustamento de Conduta (TAC) firmado juntamente com o IBAMA que tem por objetivo definir as obrigações a serem cumpridas pela Comissão Nacional de Energia Nuclear - CNEN, necessárias à regularização do licenciamento ambiental de suas atividades. Estas obrigações irão consolidar a Gestão Ambiental, seguindo as diretrizes e estrutura do Sistema de Gestão Integrada (SGI) do IPEN/CNEN-SP [13].

\subsubsection{Programa de Monitoramento Ambiental dos Compostos Químicos Estáveis do IPEN (PMA-Q)}

O PMA-Q faz parte do programa de gestão ambiental do IPEN em conjunto com o Programa de Monitoração Radiológica Ambiental (PMRA). No PMA$Q$ diversas análises ambientais são realizadas in situ, no momento em que as amostras são coletadas e posteriormente em laboratório. Conforme o relatório anual do PMA-Q este programa estabelece os requisitos básicos para assegurar ausência de riscos potenciais, diretos ou indiretos, à saúde humana, dentro das 
dependências do IPEN (onde são manuseados produtos químicos, biológicos e radioativos) ou no seu entorno. As informações associadas a este Programa também visam prover o IPEN de documentação técnica necessária para atendimento ao TAC, firmado juntamente ao IBAMA [12].

O principal objetivo do PMA-Q é elaborar um banco de dados com informações suficientes para: adequar os procedimentos de amostragem, análise e tratamento de dados às normas técnicas vigentes, avaliar o impacto das atividades desenvolvidas na instituição à qualidade dos recursos hídricos frente aos dispositivos legais, desenvolver metodologias analíticas para viabilizar a avaliação de todo o escopo de compostos químicos contemplado nas legislações aplicáveis, demonstrar o atendimento dos procedimentos adotados na liberação de efluentes líquidos aos limites autorizados e adequados às exigências legais, manter um registro contínuo dos efeitos das instalações sobre os níveis naturais de compostos químicos da região sob influência do campus, complementando os registros radioativos existentes, detectar eventuais falhas e programar medidas corretivas. 


\section{EMBASAMENTO TEÓRICO}

\subsection{Desenvolvimento dos Valores Máximos Permitidos para os Metais}

Os metais são conhecidos por causarem problemas à saúde quando ingeridos em determinadas concentrações, desta forma existem diversas legislações no Brasil e no mundo que definem valores para sua concentração em diversos meios, como água e alimentos entre outros compostos. Estas legislações, listas ou documentos definem os conhecidos Valores Máximos Permitidos (VMPs), que são critérios de qualidade que garantem o uso de determinado material [21].

Os VMPs começaram a ser estipulados após a Segunda Guerra Mundial, primeiramente delimitando o uso industrial de alguns compostos. No entanto existiam diversas listas com concentrações divergentes, então em 1963, durante o Simpósio Internacional em Valores Máximos Permitidos (International Symposium on Maximum Allowed Concentrations) foi recomendado que houvesse uma comissão internacional para a determinação de valores unificados para todos os VMPs.

Em 1966, o Subcomitê de VMPs e outras associações se reuniram em Viena (Áustria) e foi atribuída à alguns grupos a responsabilidade de avaliar o embasamento científico dos VMPs de algumas substâncias. Mas somente em 1968 em Estocolmo (Suécia) foi recomendada a formação de um grupo específico para a análise de toxicidade de metais, O Comitê Científico de Toxicidade de Metais (SCTM - Scientific Committee on the Toxicology of Metals) que foi estabelecido em 1969 em Tóquio. O primeiro encontro deste grupo foi realizado em Estocolmo em $1970[11]$

Porém as dificuldades com a formulação de VMPs confiáveis foram reconhecidas por outras entidades internacionais ligadas à saúde e ao meio 
ambiente, e estas entidades iniciaram em conjunto o Programa Internacional de Segurança em Química (International Programme on Chemical Safety - IPCS), cujo objetivo maior é divulgar e realizar a avaliação dos efeitos de alguns elementos químicos para a saúda humana e na qualidade do meio ambiente. Desde então, o desenvolvimento dos VMPs vem ocorrendo com base em estudos científicos [11].

De acordo com UMBUZEIRO (2011) para a determinação dos VMPs é realizada uma série de estudos que levam em consideração a toxicidade destes contaminantes para o meio ambiente, para os animais e seres humanos [21]. Nos itens abaixo são apresentadas algumas características, quanto à toxicidade dos metais avaliados neste estudo.

\subsubsection{Cádmio (Cd)}

O cádmio é um metal quimicamente similar ao zinco, e geralmente ocorre na natureza em conjunto com zinco e chumbo. Algumas espécies de sais e complexos de cádmio apresentam solubilidade em água, e portanto, também apresentam grande mobilidade. Pode ser encontrado em elevadas concentrações no solo e no ar, principalmente em regiões próximas à mineração de metais não ferrosos e indústrias de refino de metais. A principal fonte natural do lançamento de cádmio na atmosfera é a atividade vulcânica, pois as emissões ocorrem tanto durante os períodos de emissão como nos períodos de baixa atividade [22, 11].

O cádmio e seus compostos ocorrem na atmosfera, geralmente, em forma de material particulado suspenso, derivado de borrifos do mar, emissões industriais ou erosão de solo. Em processos que envolvem temperaturas mais altas, pode haver emissão de cádmio na forma de vapor. A sua forma mais abundante na atmosfera é o óxido de cádmio, embora também haja abundância de outros sais de cádmio, como cloreto [23].

As fontes de cádmio no esgoto doméstico podem ser: excretos humanos, corrosão de tubulações de cobre galvanizado, descarte inadequado de baterias de $\mathrm{Ni}$-Cd e o descarte inadequado de efluente industrial. Também são responsáveis 
pela contaminação por cádmio os processos de fabricação de cimento e queima de combustíveis fósseis [23, 24].

Este elemento pode estar presente nos sistemas aquáticos devido á intemperismos, erosão de solo e da camada de rocha viva, às operações industriais, vazamento de aterros e locais contaminados e também pelo uso de lodos de esgoto e de fertilizantes na agricultura [23, 25].

Rios contaminados com cádmio podem dissipar esta contaminação por longas distâncias. Enquanto as espécies dissolvidas de cádmio na água são facilmente mobilizadas, as insolúveis são consideradas quase que imóveis. Quando o solo é contaminado com cádmio, este metal tende a ser mais disponível em $\mathrm{pH}$ mais baixo. A forma química como este elemento encontra-se e outras condições ambientais, tais como $\mathrm{pH}$, salinidade e potencial redox são extremamente importantes para que sua disponibilidade e remobilização sejam determinadas em solo ou sedimento, por exemplo, a absorção de cádmio por plantas decresce com o aumento do $\mathrm{pH}$ do solo, pois os hidróxidos, carbonatos e oxalatos de cádmio são insolúveis em água [23, 24]

O cádmio é removido da atmosfera por deposição seca e por precipitação, podendo precipitar como compostos insolúveis ou formar complexos. As condições climáticas também contribuem para o transporte do cádmio através dos cursos d'água [23, 25, 24].

O cadmio é captado e retido por plantas aquáticas e terrestres e normalmente se concentra nos rins e fígado dos animais que se alimentam destas plantas. Os peixes também possuem a capacidade de bioacumular os metais, as concentrações encontradas nos peixes podem até mesmo suplantar a concentração de metal do meio. As principais fontes de contaminações por cádmio ao ser humano são por ingestão ou se dão pelo hábito de fumar. O cádmio é tido como um poluente importante, portanto foi incluído na lista de substâncias e processos potencialmente perigosos ao planeta pelo Programa Ambiental das Nações Unidas de Registro Internacional de Produtos Químicos Potencialmente 
Tóxicos (International Register of Potentially Toxic Chemical of United Nations Environment Program - IRPTC) [23, 26, 25].

Uma pequena quantidade deste metal é comumente absorvida pelo ser humano diariamente, no entanto quando ingerido em grandes concentrações via oral (através de comida ou bebidas contaminadas) pode resultar em efeitos gastrointestinais agudos, acompanhados de diarreia e vômitos. Inalação aguda de cádmio pode causar pneumonia química severa, porém a inalação de pequenas concentrações de cádmio por longo período de tempo pode causar doença pulmonar obstrutiva crônica (grupo de doenças que causam o bloqueio do fluxo de ar) ou até mesmo câncer nos pulmões, e a inalação ou ingestão de grandes concentrações por longo período de tempo podem causar disfunção renal [11, 24].

Como forma de monitoramento, pode-se detectar como primeiro problema causado pela contaminação por cádmio a proteinúria de baixo peso molecular, ou seja, excreção urinária com altas concentrações de proteínas de baixo peso molecular produzidas pelo organismo. O cádmio também é considerado carcinogênico (Grupo 1 - carcinogênico para humanos) pela Agência Internacional de Investigação sobre o Câncer (International Agency for Research on Cancer IARC) [11].

Este metal tem diversas aplicações na indústria, são alguns exemplos de suas aplicações: a utilização como anticorrosivo em aço galvanizado, como pigmento em plásticos, baterias, componentes eletrônicos e reatores nucleares. Porém o seu uso vem sendo restringido em muitos países [22, 11].

\subsubsection{Chumbo (Pb)}

O chumbo é abundante na crosta terrestre, suas maiores fontes naturais são emissões vulcânicas, intemperismo geoquímico e névoa aquática, além de uma pequena fonte de chumbo, que é o decaimento do radioisótopo radônio, lançado por fontes geológicas. O chumbo utilizado nas indústrias é aplicado cerca de $40 \%$ em sua forma metálica, $25 \%$ em ligas e 35\% em compostos químicos. É geralmente encontrado na natureza por conta de contaminações de fundições e fábricas de 
baterias, bem como pelo uso direto de agentes químicos contendo chumbo como fertilizante [27, 28].

As baterias de chumbo são compostas por um ânodo de chumbo metálico $\left(\mathrm{Pb}^{0}\right)$, um o cátodo de dióxido de chumbo $\left(\mathrm{PbO}_{2}\right)$ e uma solução eletrolítica de ácido sulfúrico $\left(\mathrm{H}_{2} \mathrm{SO}_{4}\right)$. As placas utilizadas também são compostas por outros elementos como antimônio, arsênio, bismuto, cádmio, cobre, prata e estanho. Nestas baterias ocorrem reações como apresentado na Equação 1 [27] [29]. 0 Processo de reciclagem destas baterias também pode causar impactos ambientais nocivos, pois envolve três etapas: quebra, redução e refinamento do chumbo, podendo gerar poeira contaminada, eletrólito ácido, chumbo particulado e rejeitos contaminados [27].

Ânodo:

$$
\mathrm{Pb}_{(s)}^{0}+\mathrm{SO}_{4(a q)}^{2-} \rightarrow \mathrm{PbSO}_{4(s)}+2 e^{-}
$$

$$
\frac{\text { Cátodo: } \mathrm{PbO}_{2(s)}+\mathrm{SO}_{4(a q)}^{2-}+4 \mathrm{H}_{(a q)}^{+}+2 e^{-} \rightarrow \mathrm{PbSO}_{4(s)}+2 \mathrm{H}_{2} \mathrm{O}_{(l)}}{\text { Reação Total: } \mathrm{Pb}_{(s)}+\mathrm{PbO}_{2(s)}+2 \mathrm{H}_{2} \mathrm{SO}_{4(a q)} \rightarrow 2 \mathrm{PbSO}_{4(s)}+2 \mathrm{H}_{2} \mathrm{O}_{(l)}}
$$

Estima-se que cerca de 300 milhões de toneladas produzidas de chumbo, ainda persistem em forma de contaminação. As atividades de mineração e fundição de chumbo primário (oriundo de minério) e secundário (oriundo da recuperação de sucatas ou baterias) são fontes importantes de emissão de chumbo. Também eram grandes fontes de emissão deste metal os combustíveis aditivados com chumbo, mas a sua utilização para esta finalidade já foi eliminada por muitos países, inclusive pelo Brasil que foi um dos pioneiros nesta questão [30]. Cerca de $80 \%$ da ingestão de chumbo diária de um ser humano ocorre pela ingestão de alimentos, sujeiras ou poeira. O chumbo pode afetar quase todos os sistemas do corpo humano, sendo o sistema nervoso central o mais sensível [27, 31].

O chumbo é o metal inorgânico mais estudado dentre todos os agentes tóxicos. A exposição ao chumbo no ambiente ocupacional pode ocorrer das mais diversas formas, além da exposição no meio ambiente comum. Os riscos de contaminação e o monitoramento é geralmente realizado via análise sanguínea, porém, este método possui algumas limitações, como o risco de contaminação 
durante o tratamento da amostra de sangue. Normalmente o chumbo se acumula nos dentes e esqueleto [11].

A contaminação por chumbo pode causar efeitos no sistema nervoso central, rins, sistema cardiovascular, sistemas endócrino, sistema imunológico, trato intestinal e sistema reprodutor masculino (afetando a qualidade dos espermatozoides). Além destes efeitos diretos, o chumbo também ultrapassa a placenta de gestantes, podendo causar problemas no sistema nervoso fetal, além de ser imobilizado no esqueleto durante a gravidez, provocando efeitos no feto e em lactentes [11].

Geralmente uma pequena fração de chumbo é encontrada na forma dissolvida na água, pois a maior parte encontra-se ligada ao sedimento, mas a captação e acúmulo de chumbo em organismos aquáticos pode ocorrer pela água e/ou pelo sedimento, e é influenciada por vários fatores ambientais, tais como, temperatura, salinidade e $\mathrm{pH}$. O acúmulo de chumbo pelos peixes alcança equilíbrio após algumas semanas, e este chumbo absorvido acumula-se nas brânquias, fígado, rins e ossos. A distribuição deste metal no organismo animal está diretamente ligada ao metabolismo do cálcio e ferro, sabe-se que baixa ingestão de cálcio e ferro favorece a absorção de chumbo pelo organismo, assim geralmente é encontrado em baixas concentrações [27, 32, 33].

Plantas também são contaminadas por chumbo presente no solo e água, embora a quantificação desta contaminação seja dificultada pela utilização de agentes químicos contaminados com chumbo diretamente na agricultura [27, 32 , 33].

\subsubsection{Cobre $(\mathrm{Cu})$}

O cobre é distribuído na natureza na sua forma elementar, como sulfetos, arsenitos, cloretos, carbonatos e ocorre em muitos minérios na forma de óxidos. Por ser um elemento que compõe a crosta terrestre, uma de suas grandes fontes é a poeira, outras fontes são os vulcões, os processos biogênicos (processos naturais realizados por organismos, plantas e outros seres), incêndios florestais e 
névoas aquáticas. Os ventos também contribuem com a distribuição deste metal, bem como os processos de precipitação e fluxo das águas [34]. O cobre é utilizado mundialmente nos processos de manufatura de moedas, produção de inseticidas, fungicidas, algicidas, desinfetantes, tintas anti incrustantes, baterias, eletrodos e pigmentos, além de tratamentos galvanoplásticos, dispositivos intrauterinos de contracepção, fios, condutores e tubulações. As atividades de refino e mineração de cobre são as fontes mais importantes de emissão deste metal [35].

Nos anos 2000 sabia-se que o fluxo de cobre decorrente de fontes antrópicas era três vezes maior que o fluxo de cobre decorrente de fontes naturais. O cobre também compõe grande parcela das tubulações de abastecimento público de água, o que pode acarretar em aumento da concentração deste metal na água, dependendo da acidez, dureza, temperatura, concentração de dióxido de carbono, tempo de residência da água na tubulação, tempo de uso da tubulação e sua extensão [35].

A toxicidade do cobre normalmente decresce com o aumento da dureza da água pela competição entre cálcio e cobre pelos sítios de adsorção em superfícies biológicas. E ainda que este seja tóxico em concentrações elevadas, por ser um metal essencial, quando em falta no organismo pode ser um limitante ou causar sintomas de deficiência [34, 35].

Concentrações elevadas de cobre podem eliminar espécies aquáticas mais sensíveis. Quanto às plantas a concentração deste metal depende de quatro fatores: genético, tipo de solo, clima e estágio de maturidade da planta [35].

Este metal é amplamente utilizado no controle de algas e também como aditivo em alimentos. É um elemento traço essencial, pois é imprescindível para o funcionamento de várias enzimas. A absorção depende da concentração ingerida, sua forma química, além da composição da dieta, como por exemplo, quanto maior a presença de zinco menor a presença de cobre no organismo [11].

Como citado anteriormente, como as tubulações utilizadas para o transporte de água para o abastecimento público são constituídas de cobre, o 
consumo de água contribui para a ingestão deste metal. A absorção de cobre é determinada por mecanismos realizados no fígado, e a excreção biliar aumenta se há excesso de cobre no organismo. Este elemento pode ser encontrado, normalmente, em todos os órgãos, porém as maiores concentrações são encontradas no fígado e no cérebro, em adultos ou crianças. É comumente excretado via biliar e baixas concentrações podem ser encontradas na urina [11].

O cobre é um elemento essencial à vida em pequenas quantidades. $\mathrm{A}$ ingestão de altas concentrações de sais de cobre pode causar problemas intestinais, podendo ser o primeiro sintoma náuseas e até mesmo problemas hepáticos. Em casos severos problemas sistêmicos podem afetar rim. Pouco se sabe sobre inalação de cobre e efeitos causados por fumaça industrial rica em cobre $[11,36]$.

\subsubsection{Crômio (Cr)}

O minério de crômio mais abundante na crosta terrestre é a cromita, contendo de 40 a 50 \% de crômio em sua composição. O crômio pode ocorrer na forma elementar ( $\left.\mathrm{Cr}^{\circ}\right), \mathrm{Cr}^{2+}, \mathrm{Cr}^{3+} \mathrm{e} \mathrm{Cr}^{6+}$. A maioria do crômio hexavalente disponível (o mais reativo) é oriundo de fontes antrópicas, e a forma hexavalente é de alta toxicidade ao homem, embora a forma trivalente também possa ser tóxica dependendo da forma e intensidade da exposição [37]. Este elemento pode ser encontrado naturalmente em água, mas em concentrações baixas [38].

O crômio é muito utilizado na indústria de ligas metálicas, por suas propriedades mecânicas (dureza e resistência ao atrito) e químicas (resistência a corrosão e ao desgaste). As maiores fontes antrópicas de lançamento de crômio e seus compostos no meio ambiente são [37, 39, 40]:

- Emissões de fábricas de cimento;

- Resíduos de cimento da construção civil;

- Soldagem de ligas metálicas;

- Fundições;

- Produção de aço e ligas; 
- Tratamentos galvanoplásticos;

- Lâmpadas;

- Atividades de mineração;

- Rejeitos urbano e industrial;

- Incineração de rejeitos;

- Cinzas de carvão;

- Curtumes;

- Conservantes de madeira; e

- Fertilizantes.

O crômio (trivalente) pode ser encontrado em todos os órgãos humanos, em adultos ou crianças, mas as maiores concentrações são geralmente encontradas nos tecidos dos pulmões, e esta concentração tende a aumentar com o aumento da idade. Este elemento é eliminado do organismo, em sua maioria via urina. $\mathrm{O} \mathrm{Cr}^{3+}$ pode ser um suplemento nutricional, tendo grande participação na metabolização da glicose. A maior concentração absorvida de crômio por humanos é oriunda da alimentação, origem inalatória e de pequenas concentrações solubilizadas na água [11].

Os problemas mais frequentes causados pela absorção de crômio são alergias na pele, podendo chegar a feridas e úlceras na mucosa nasal, geralmente oriundos do contato com $\mathrm{Cr}^{6+}$, este também oferece grande risco de câncer em casos de exposição inalatória de longo prazo [11].

Os compostos de crômio em geral não são voláteis, e encontram-se na forma de partículas sólidas no meio ambiente. Quando em águas superficiais, grande parte de sua concentração é transportada para o sedimento e uma pequena parcela encontra-se solúvel ou insolúvel na água. O crômio pode ser acumulado por espécies aquáticas, e alguns estudos mostram acumulação deste no baço, brônquios e intestino de peixes [37]. 


\subsubsection{Zinco $(\mathrm{Zn})$}

É um metal encontrado na natureza largamente utilizado na indústria automobilística na forma de ligas resistentes à corrosão e em tratamentos superficiais, também é utilizado no enriquecimento de solos. Pode ser encontrado em altas concentrações em alimentos ricos em proteínas, como as carnes. $O$ zinco é um elemento essencial à vida, mas em grandes quantidades pode causar malestar e até mesmo doenças [41]

A deficiência ou excesso deste metal no organismo humano podem apresentar riscos, embora a deficiência de zinco seja algo comum na vida, principalmente para pessoas que não possuem carne incluída em sua dieta [11]

A toxicidade do zinco é considerada baixa para humanos. A inalação de fumaça de zinco, originárias de processos de soldagem ou outros processos industriais, pode causar "febre do fumo metálico" uma doença similar à gripe. No entanto, fumaça de zinco, oriunda de bombas (cloreto de zinco) pode causar sérias doenças pulmonares, podendo ser fatal. A ingestão de alimentos contaminados por zinco, oriundo de superfícies galvanizadas, podem causar diarreia, vômitos, náuseas, o que é raramente fatal. Deve-se tomar cuidado com a ingestão de suplementos ricos em zinco, pois o excesso deste metal pode suprimir a absorção de cobre pelo intestino, causando assim outros problemas de saúde [11].

\subsubsection{Estanho (Sn)}

O estanho é um metal raramente encontrado na forma pura, geralmente é encontrado em forma de cloreto, sulfato ou óxido, mas mesmo ligado a outros elementos é encontrado em pequenas quantidades na crosta terrestre. O estanho na natureza pode ser oriundo de gases, poeiras ou fumaças de processos de refinamento, incineração de resíduos ou queima de combustíveis fósseis [42].

Este metal é amplamente utilizado em processos industriais, mas sua principal aplicação é na produção de folhas-de-flandres [43]. 
É encontrado em muitos solos, assim é encontrado em alguns alimentos em pequena quantidade. Grande parte dos compostos inorgânicos de estanho não são tóxicos por conta de sua baixa solubilidade. Quando presente no meio ambiente pode passar por reações químicas ou biológicas, sendo assim transformado em compostos mais tóxicos, embora a tendência de formação de óxido de estanho no meio ambiente ajude a diminuir sua toxicidade, uma vez que possui baixa solubilidade, baixa absorção, baixa taxa de acúmulo nos tecidos e rápida excreção pelo organismo. $\mathrm{Na}$ forma de cloreto o estanho apresenta toxicidade moderada $[44,11]$.

O estanho não é um metal essencial, mas está presente nos tecidos humanos. A ingestão de estanho geralmente ocorre por alimentos embalados em latas de folha-de-flandres [42]. O dano máximo ao ser humano já registrado é irritação gástrica causada por altas exposições [43].

O organismo absorve somente um pequeno percentual dos sais solúveis de estanho, a parte do corpo que mais acumula o estanho absorvido são os ossos, que podem ser severamente prejudicados em exposições crônicas. Os meios de excreção deste metal podem ser diversos, depende da forma química em que este é absorvido e o meio de exposição [11].

A exposição às fumaças de estanho pode causar uma doença pulmonar que não causa nenhuma reação ou disfunção dos tecidos. Grandes níveis de ingestão de compostos inorgânicos de estanho podem causar dor abdominal ou anemia [11].

\subsubsection{Níquel (Ni)}

O níquel pode ser encontrado na forma de cloreto, sulfato, sulfito ou óxido, que são em geral solúveis em água. De acordo com a Agência de Substâncias Tóxicas e Registro de Doenças (Agency for Toxic Substances and Disease Registry - ATSDR) o níquel é o 24ํㅡㄹ elemento mais abundante na crosta terrestre [45]. 
Este metal possui propriedades mecânicas que o torna componente de diversas ligas metálicas, e é muito utilizado na produção de aço inoxidável [45].

Seu estado de oxidação mais comum é o $\mathrm{Ni}^{2+}$, geralmente encontrado em nível de traço na água e solo. Este elemento não se concentra em peixes, ao contrário do que ocorre em algumas plantas. O níquel é encontrado em nível de traços no meio ambiente $[46,11]$.

Para as pessoas a alimentação é a maior fonte de níquel. A ingestão de altas concentrações pode causar dores estomacais, alterações sanguíneas adversas (como o aumento de hemácias) e renais. Em 1990 a Agência Internacional de Pesquisa do Câncer (International Agency for Research on Cancer - IARC) determinou que compostos de níquel são carcinogênicos, principalmente partículas insolúveis $[46,11]$.

As consequências da inalação de níquel vão depender do tamanho das partículas e também da solubilidade do composto, quanto menores as partículas, maior quantidade vai chegar ao pulmão e quanto menos solúvel mais tempo vai permanecer no organismo. O níquel é normalmente excretado pela urina. Também pode causar reações alérgicas [45].

\subsubsection{Ferro (Fe)}

O ferro não é um elemento conhecido por características tóxicas, mas pode trazer problemas, tais como, manchas em utensílios domésticos, sanitários e roupas, pode ocorrer o desenvolvimento de ferro-bactérias e a deposição do ferro em tubulações. Este é o quarto elemento mais abundantes da terra, compondo $30 \%$ da massa do planeta. Juntamente com o alumínio é o metal mais importante da terra, aparece em sua maior parte combinado com o oxigênio, silício ou enxofre. A maioria do ferro na terra encontra-se na forma de $\mathrm{Fe}^{2+}$, que é rapidamente oxidado a $\mathrm{Fe}^{3+}$, este insolúvel em água. Este metal pode facilmente passar por mudança de valência e complexação em presença de oxigênio [47, 48]. 
Exposição excessiva ao ferro, bem como sua deficiência no organismo pode causar consequências graves à saúde. Ingestão ou absorção crônica de altas concentrações de ferro pode acarretar em problemas cardíacos ou hepáticos letais $[11,48]$.

O mecanismo de obtenção de ferro pelos vegetais envolve a absorção do metal pela raiz e o transporte do mesmo até as folhas [47].

Os compostos de ferro mais usados na indústria são os óxidos, sulfetos e carbonatos, sendo o principal uso do ferro a produção de aço. As principais fontes de exposição industrial ao ferro e seus compostos são [47]:

- Atividades de mineração;

- Processos de fundição com coque;

- Decomposição térmica do ferro pentacarbonil;

- Processos de tratamento de minério de ferro ou sucatas de ferro;

- Redução de óxido férrico por hidrogênio;

- Eletrodeposição de sais de ferro.

São estas também fontes de contaminação do meio ambiente por ferro, assim como os processos de mineração, fundição, soldagem, polimento de metais, uso como agente antidetonante na gasolina e também o lançamento de efluente indústria com alta carga de ferro. Como consequência da mineração do ferro também pode haver contaminação do meio ambiente por ácidos, pois ocorre produção de lixiviado ácido pela exposição de minérios contendo enxofre à umidade e ao oxigênio [47].

$\mathrm{Na}$ água o ferro pode ocorrer na forma iônica (di ou trivalente), se a água estiver livre de oxigênio ou com pH abaixo de 3 , complexado, em estado coloidal ou disperso. As espécies aquáticas são extremamente sensíveis a variações de $\mathrm{pH}$. O ferro pode estar diretamente ligado à dinâmica de outros elementos em águas superficiais, sendo este extremamente importante para o controle da proliferação de algas entre outros processos naturais [47, 49]. 


\subsubsection{Bário $(\mathrm{Ba})$}

Geralmente o bário ocorre na natureza na forma de sulfato ou carbonato, que também podem estar presentes em alimentos e água potável. Os compostos menos solúveis de bário, como carbonato e sulfato, persistem mais na natureza. Outras formas mais solúveis reagem facilmente e persistem menos tempo na natureza [50].

Este elemento normalmente é encontrado próximo a áreas de exploração de minérios (barita) [51].

O sulfato de bário é muito utilizado em indústrias de óleo e gás no processo de perfuração de poços, para a composição de lamas de perfuração, além de diversas outras aplicações. Outros compostos de bário são utilizados para cerâmicas, inseticidas, raticidas e aditivos para combustíveis [50]

A toxicidade dos compostos de bário depende do seu grau de solubilidade e da espécie absorvida, quanto menos solúvel menor o efeito no organismo. Este não é um elemento essencial ao ser humano, e a ingestão de altas concentrações em água pode causar disfunções no ritmo cardíaco, paralisia e óbito, caso não seja ministrado tratamento [51].

Em sua forma iônica, o bário é rapidamente absorvido pelos pulmões ou pelo trato intestinal, no entanto o sulfato de bário não é absorvido. Após sua absorção as espécies de bário geralmente se acumulam no esqueleto e na região pigmentada dos olhos. Exposição aguda ou crônica pode resultar em intoxicação renal, hipertensão ou disfunções cardíacas. Contaminações severas podem causar arritmia cardíaca ou paralisia e até mesmo a morte, e pequenos níveis de contaminação podem causar vômito, cólicas abdominais, diarreia, dificuldade para respirar e alta ou baixa pressão arterial $[11,50]$

\subsubsection{Manganês (Mn)}

O manganês é muito presente na natureza, geralmente em forma de óxido, sulfeto, carbonato e silicato, em rochas ou no solo [11]. 
Sua concentração varia de acordo com a sua fonte, mas em geral os alimentos são responsáveis por grande parte de sua absorção no organismo humano. É absorvido pelo organismo em baixas concentrações, e é normalmente excretado pelo intestino, porém pode acumular-se no cérebro [11, 52].

Este elemento é um metal essencial para o homem, embora a exposição a níveis elevados possa causar problemas graves, tal como o manganismo (doença que causa distúrbios psiquiátricos e motores) [11,52]. Este metal está presente em muitos processos fisiológicos (na formação de ossos, função reprodutiva e metabolismo de carboidratos e lipídios), é considerado um metal importante para o bom funcionamento do organismo, vegetais (no processo de respiração) e animais, mas a exposição aguda ou crônica ao manganês pode provocar síndrome parkinsoniana ou problemas neurológicos [53, 54, 55].

O comportamento do manganês em água é muito parecido com o do ferro, mas sua ocorrência é mais rara. [52]. O transporte de manganês na água é favorecido em variações de $\mathrm{pH}$, em meio ácido pode atingir até águas subterrâneas e depois é precipitado quando ocorre o aumento do $\mathrm{pH}$. Nos rios são encontradas concentrações maiores do metal dissolvido do que em suspensão. O manganês em sua forma bivalente é a principal forma encontrada na água [53].

De acordo com alguns estudos, nas plantas a acumulação de manganês acontece em concentrações maiores nas partes superiores do que nas raízes [53].

O manganês é usado industrialmente na produção de vidro, ligas ferromanganês e ferrosilíliciomanganês. Este metal ocorre naturalmente em alimentos e pode estar presente em suplementos alimentares e também é aplicado em fertilizantes, tintas e cosméticos [53, 54, 55].

\subsubsection{Boro (B)}

O boro é um semimetal, que ocorre naturalmente em grandes quantidades, normalmente em forma de sais, como o borato, predominantemente nos oceanos. Os compostos de boro não são considerados tóxicos, e também não 
é reconhecido como um poluente prioritário. É um elemento importante para o crescimento de plantas, portanto geralmente os vegetais e frutas são grandes fontes de boro. É aplicado na fabricação de vidros, fertilizantes, pesticidas, cosméticos e sabão em pó $[11,56]$.

Este elemento não está muito presente no ar, por conta da baixa volatilidade de seus compostos. Geralmente há a presença deste elemento em água subterrânea e água superficial, oriundo da absorção de rochas e do solo, dependendo das características da região [56, 57].

Exposição aguda ao boro pode causar efeitos no estômago, intestino, fígado, cérebro e pode causar até a morte [56,57]. 
Os rejeitos líquidos gerados pela indústria são denominados efluentes industriais e são definidos de acordo com a norma brasileira NBR 9800/1987 como o despejo líquido proveniente do estabelecimento industrial, compreendendo emanações de processo industrial, águas de refrigeração poluídas, águas pluviais poluídas e esgoto doméstico. Atualmente existem leis municipais, estaduais e federais que dispõem sobre a disposição destes rejeitos líquidos, no entanto, em torno da preocupação com os recursos hídricos, a legislação brasileira foi relativamente lenta, e ainda vem sendo desenvolvida [58] [59].

\subsection{Histórico Legal quanto ao Descarte de Efluentes Líquidos Industriais}

Levando em consideração o desenvolvimento legislativo, as preocupações com o meio ambiente no Brasil tiveram início com o Decreto Federal 16.300, de 1923, que previu a possibilidade de impedir que fábricas prejudicassem a saúde de pessoas vizinhas. Este também incorporou a expressão Vigilância Sanitária como o controle sanitário, assim como órgão responsável pelo licenciamento e fiscalização de estabelecimentos comerciais e industriais, controle de logradouros públicos, defesa sanitária marítima e fluvial e controle do exercício profissional da área da saúde [60] [59].

A Constituição Federal de 1934 foi a que primeira a abordar o tema hídrico de forma clara. Estabeleceu a nacionalização das riquezas do subsolo, e estabeleceu como domínio da União lagos e quaisquer correntes em terrenos do seu domínio (disciplinou o domínio dos recursos hídricos, concedendo-os a União e ao Estado, respectivamente). A água se constituía em elemento essencial para a geração de riquezas econômicas e para o desenvolvimento, especialmente como fonte de energia elétrica de acordo com a abordagem desta Carta Constitucional [61]. 
Posteriormente, os objetivos do Código das Águas (Decreto - Lei Nº 24.643 de 1934) ficam claros desde suas considerações preliminares, visto que o uso das águas no país está regido, até então, por legislação obsoleta e em desacordo com as necessidades e interesses nacionais. O instrumento pretendia dotar o país de uma legislação adequada que permitisse ao público controlar e incentivar o aproveitamento industrial da água. O Código, ainda que promulgado com o principal objetivo de regulamentar a utilização da água como fonte geradora de energia elétrica, possuía mecanismos capazes de assegurar a utilização sustentável dos recursos hídricos, bem como garantir o acesso público às águas. O Código das Águas, foi o primeiro instrumento legal que fez referência aos principais conceitos de Gerenciamento de Bacias Hidrográficas. Tal como no $\S 3^{\circ}$ do artigo 71, que diz que o uso das águas para as primeiras necessidades da vida terá sempre preferência, sobre quaisquer outras aplicações (hierarquia de usos) [62]. O Código das Águas, é considerado como uma das mais completas leis de águas já produzidas, e encontra-se vigente até os dias atuais, com ressalvas para alguns dispositivos parcialmente ou totalmente revogados por leis posteriores.

Em vigor até hoje, embora tenha recebido diversas emendas ao decorrer dos anos, o Código Penal Brasileiro (Decreto - Lei 2.848 de 1940) estabelece a proteção da água potável contra envenenamento, corrupção e poluição [63].

A Constituição Federal de 1946 alterou a questão do domínio hídrico, ela determinava ser de competência de a União legislar sobre riquezas do solo, mineração, metalurgia, águas, energia elétrica, florestas, caça e pesca. Tal competência não excluía a legislação estadual supletiva ou complementar. Descrevia entre os bens da União e entre os bens dos Estados, os lagos e rios em terrenos de seu domínio e os que possuem nascente e foz no território estadual. Com isto desapareciam os "rios municipais", tal como estavam definidos no Código das Águas. A Carta de 1946 dizia que as quedas d'água eram consideradas como regime de propriedade distinta da do solo, para efeito de aproveitamento industrial ou de exploração e também determinava que o aproveitamento de recursos minerais e de energia hidráulica dependia de autorização ou concessão, e só poderiam ser dadas a brasileiros ou empresas do país. Esta determinação não se aplicava ao aproveitamento de energia hidráulica de potência reduzida [64]. 
O Código Nacional de Saúde (Lei $n^{\circ} 2.312$ de 1954) estabeleceu algumas restrições e obrigações por parte das indústrias no sentido do controle de lançamento de resíduos líquidos. Este Código falou sobre a possibilidade do controle da poluição através da qualidade do corpo receptor [65].

O Decreto Federal 50.877 (1961) foi a primeira lei federal específica sobre poluição das águas. Estabeleceu a exigência de tratamento dos resíduos líquidos, sólidos ou gasosos domiciliares ou industriais antes do seu lançamento nas águas receptoras. Previu a classificação das águas de acordo com os seus usos, com as respectivas taxas de poluição permissíveis, ainda a serem estabelecidas na época. No art. $3^{\circ}$ ela define a poluição como qualquer alteração das propriedades físicas, químicas e biológicas das águas, que possa importar em prejuízo à saúde, à segurança e ao bem-estar das populações e ainda comprometer a sua utilização para fins agrícolas, industriais, comerciais, recreativos e, principalmente, a existência normal da fauna aquática. No art. $4^{\circ}$ estabelece os padrões de água poluída [66].

O Código Florestal (1965) menciona pela primeira vez a reserva de faixas de proteção à margem dos rios [67].

A Constituição Federal de 1967 praticamente repetiu os termos da Carta anterior (A Constituição Federal de 1946), no que tange os bens da União e dos Estados [68].

Com o Decreto-Lei 303 de 1967 criou-se o Conselho Nacional de Controle da Poluição Ambiental. Estendeu-se o conceito de poluição aos meios aéreos e terrestres e introduziu a expressão meio ambiente [69]. No seu artigo $1^{\circ}$ define como poluição qualquer alteração das propriedades físicas, químicas ou biológicas do meio ambiente (solo, água e ar).

Com o Decreto Federal 73.030 de 1973 criou-se a Secretaria Especial do Meio ambiente (SEMA). Houve a consolidação da visão global do problema ambiental como um todo e introduziu o conceito de proteção à natureza, de equilíbrio ecológico e de preservação de espécies [70]. 
O Decreto-Lei 1.413 (1975), que dispões sobre o controle da poluição do meio ambiente provocada por atividades industriais, estabeleceu o zoneamento urbano em áreas críticas de poluição [71].

A Portaria 013 Minter (1975) estabeleceu pela primeira vez em âmbito federal um critério de classificação de águas interiores, fixando padrões de qualidade e parâmetros a serem observados para cada classe, bem como o uso a que se destinam [72].

A Portaria 0536 Minter (1976) fixou, pela primeira vez, padrões específicos de qualidade das águas para fins de balneabilidade (águas destinadas a recreação de contato primário, como banho ou atividades esportivas) ou recreação de contato primário (atividades de contato direto e prolongado com a água, tais como, banho ou atividades esportivas) [73].

O Decreto Federal 81.107 (1977) definiu o elenco de atividades sob as quais os Estados não tinham jurisdição (poder), por serem consideradas de interesse da segurança nacional [74].

A Portaria Interministerial 01 (1978) recomendava que fossem levadas em conta condições de produção de energia hidrelétrica e de navegação para efeito de classificação e enquadramento de águas federais e estaduais [75].

A Portaria Interministerial 90 (1978) criou o Comitê Especial de Estudos Integrais de Bacias Hidrográficas (CEEIBH), com atribuições de classificar os cursos d'água da União, estudar de forma integrada e acompanhar o uso racional dos recursos hídricos federais com o objetivo de obter o melhor aproveitamento múltiplo de cada bacia [76].

A Lei Federal 6.803 (1980) estabeleceu as diretrizes básicas para o zoneamento industrial nas áreas críticas de poluição, onde se arrola sobre a possível criação de três classes de áreas destinadas à atividade industrial [77]: 
- Zona de uso estritamente industrial: onde as atividades industriais ali desenvolvidas podem prejudicar o bem-estar e/ou saúde da população vizinha, tais como, geração de efluente, ruído e radiação;

- Zona de uso predominantemente industrial: atividades ali desenvolvidas não causarão transtornos maiores à população, tais como, incomodo noturno;

- Zona de uso diversificado: atividades ali desenvolvidas não prejudicarão as atividades urbanas e rurais.

Em 1981 foi promulgada a Lei Federal N. 6.938 que estabelece a Política Nacional do Meio Ambiente e que tem por objetivo a preservação, melhoria e recuperação da qualidade ambiental propícia à vida, visando assegurar no país condições ao desenvolvimento socioeconômico, aos interesses da segurança nacional e à proteção da dignidade da vida humana, devendo ser atendidos, entre outros, os princípios de racionalização do uso do solo, do subsolo, da água e do ar, o planejamento e fiscalização do uso dos recursos ambientais e de proteção dos ecossistemas com a preservação de áreas representativas e o acompanhamento do estado da qualidade ambiental.

Dentre os instrumentos desta política menciona-se o estabelecimento de padrões de qualidade ambiental, o zoneamento ambiental e o licenciamento e a revisão de atividades efetiva ou potencialmente poluidoras. Ou seja, esta lei define a água como um recurso ambiental do qual deve ter o seu uso planejado, racionalizado, fiscalizado, protegido e sua qualidade acompanhada [78].

O Decreto Federal 88.351, de 1983 (alterado pelo Decreto 91.305 de 1985), definiu a Política Nacional de Meio Ambiente, a criação do Sistema Nacional de Meio Ambiente (SISNAMA) e do Conselho Nacional de Meio Ambiente (CONAMA). A Política Nacional de Meio Ambiente foi desenvolvida a partir de uma série de princípios, entre eles: o equilíbrio ecológico, o planejamento do uso do solo, a proteção de ecossistemas, o controle e zoneamento de atividades 
poluidoras, o desenvolvimento de tecnologias de proteção dos recursos naturais, a recuperação de áreas já degradadas e a educação ambiental.

São atribuições do CONAMA estabelecer normas para a implementação da Política Nacional de Meio Ambiente e estabelecer normas e critérios para licenciamento de atividades efetivas ou potencialmente poluidoras, incluindo a exigência de Estudos de Impacto ambiental (EIA), quando necessário. E como decorrência dos estudos deve ser elaborado o Relatório de Impacto Ambiental (RIMA) [79].

As Resoluções CONAMA 01 (1986) e 11 (1986) definiram a obrigatoriedade, o conceito e as diretrizes do Estudo de Impacto Ambiental (EIA) e do Relatório de Impacto Ambiental (RIMA). No Artigo $6^{\circ}$ da Resolução CONAMA $01 \mathrm{diz}$ que o EIA deve desenvolver ao menos as seguintes atividades [4]:

1. Diagnóstico ambiental da área de influência do projeto antes da implantação do projeto, considerando o meio físico (o subsolo, as águas o ar, o clima, entre outros aspectos), o meio biológico e os ecossistemas naturais (a fauna e a flora) e o meio socioeconômico (o uso e ocupação do solo, usos das águas e a sócio economia);

2. Análise de Impactos Ambientais do projeto e suas alternativas, identificando e prevendo a magnitude dos prováveis impactos relevantes;

3. Definição de equipamentos e sistemas de controle para ações mitigadoras dos impactos negativos; $\mathrm{e}$

4. Elaboração de programa de acompanhamento e monitoramento dos impactos positivos e negativos.

E no Artigo $9^{\circ}$ da Resolução CONAMA 001 estabelece que o Relatório de Impacto Ambiental deve refletir as conclusões do Estudo de Impacto Ambiental [4]. 
A Resolução CONAMA 06 (1986) diz que no processo de licenciamento ambiental de atividades industriais, os resíduos gerados ou existentes deverão ser objeto de controle específico [4].

A Resolução CONAMA 20 (1986) trata da classificação das águas e estabelece limites para a emissão de efluentes. Alterou as classificações anteriormente estabelecidas pela Portaria Minter 013/76, estendendo-as às águas salobras e salinas, acrescentando vários parâmetros analíticos e tornando mais restritivos os padrões relativos a vários componentes. De acordo com esta norma "o enquadramento dos corpos d'água deve considerar não necessariamente seu estado atual, mas os níveis de qualidade que deveriam possuir para atender às necessidades da comunidade e garantir os usos concebidos para os recursos hídricos". Esta Resolução do CONAMA foi o principal instrumento na legislação da qualidade das águas de corpos receptores e de lançamento de efluentes líquidos [4].

A Constituição Federal (1988) diz que as águas minerais são bens da União, ou seja, só podem ser pesquisadas ou lavradas mediante concessão da União. São definidas como bens dos Estados "as águas superficiais e subterrâneas, fluentes, emergentes e em depósito". Esta Carta determina que a competência legislativa das águas seja determinada pela União, mas não descarta a possibilidade de que lei complementar (federal) possa autorizar os Estados a legislar sobre questões específicas [80].

A Resolução CONAMA 12 (1989) proibiu as atividades que possam colocar em risco a conservação dos ecossistemas, a proteção à biota de espécies raras e a harmonia das Paisagens nas Áreas de Relevante Interesse Ecológico (ARIES) [4].

A Lei Federal 7.797 (1989) criou o Fundo Nacional do Meio Ambiente, com o objetivo de desenvolver projetos que visem o uso racional e sustentável dos recursos naturais [81]. 
A Resolução CONAMA 10 (1993) estabeleceu competências e objetivos das Áreas de Proteção Ambiental (APA), impondo, entre outros itens, a obrigatoriedade de sistemas de coleta e tratamento de esgoto nas áreas urbanizadas [4].

A Lei 9.433 (1997) estabelece a Política Nacional dos Recursos Hídricos, que em seu artigo $5^{\circ}$ institui como um de seus instrumentos: o enquadramento dos corpos d'água em classes, segundo os seus usos preponderantes. De acordo com o seu artigo 9, este enquadramento visa assegurar a qualidade das águas de acordo com seus usos mais exigentes e diminuir os custos de combate à poluição das águas, mediante ações preventivas permanentes [82]. Esta política foi tida como um marco para o desenvolvimento sustentável dos recursos hídricos e está descrita de forma mais detalhada no item 5.2. deste trabalho.

A Resolução CONAMA 237 (1997) dá definição para o licenciamento ambiental, estudos ambientais e impacto ambiental regional e indica empreendimentos sujeitos a licença ambiental. Em seu artigo $1^{\circ}$ são adotadas as seguintes definições [4]:

- Licenciamento ambiental é o procedimento administrativo pelo qual o órgão ambiental competente licencia a localização, instalação, ampliação e a operação de empreendimentos e atividades utilizadoras de recursos ambientais, consideradas efetiva ou potencialmente poluidoras ou daquelas que, sob qualquer forma, possam causar degradação ambiental;

- Estudos Ambientais são todos e quaisquer estudos relativos aos aspectos ambientais relacionados à localização, instalação, operação e ampliação de uma atividade ou empreendimento, apresentado como subsídio para a análise da licença requerida;

- Impacto Ambiental Regional é todo e qualquer impacto ambiental que afete diretamente (área de influência direta do projeto), no todo ou em parte, o território de dois ou mais Estados. 
Nesta Resolução considerou-se a necessidade de revisão dos procedimentos e critérios utilizados para o licenciamento ambiental [4].

A Lei de Crimes Ambientais de 1998 trata dos crimes contra o meio ambiente e de infrações administrativas ambientais. Dispõe também sobre processo penal e cooperação internacional para a preservação do meio ambiente [83].

A Lei 9.984 de 2000 aprova a criação da Agência Nacional de Águas (ANA) [84]. À ANA cabe disciplinar a implementação, a operacionalização, o controle e a avaliação dos instrumentos de gestão criados pela Política Nacional de Recursos Hídricos (PNRH). Esta agência também desempenha ações de regulação, apoio à gestão dos recursos hídricos, de monitoramento de rios e reservatórios, de planejamento dos recursos hídricos, além de desenvolver programas e projetos e oferecer um conjunto de informações com o objetivo de estimular a adequada gestão e o uso racional e sustentável dos recursos hídricos. Ainda como órgão regulador, também são competências da ANA definir as condições de operação dos reservatórios, públicos ou privados, para garantir os usos múltiplos dos recursos hídricos, e avaliar a sustentabilidade de obras hídricas com participação de recursos federais. Em suma, atuando de forma distinta de outras agências reguladoras em alguns aspectos, a ANA concilia competências de implementadora da PNRH e de reguladora [85].

A Resolução CONAMA 316 (2002) dispõe sobre procedimentos e critérios para o funcionamento de sistemas de tratamento térmico de resíduos [4]. Considerando que os sistemas de tratamentos térmicos são fontes potenciais de risco ambiental e de emissão de poluentes perigosas.

A Resolução CONAMA 357 (2005) passou a substituir a Resolução CONAMA 020 que dispõe sobre a classificação dos corpos de água e diretrizes ambientais para o seu enquadramento, bem como estabelece as condições e padrões de lançamento de efluentes, e dá outras providências [4]. 
A Resolução ANA 219 (2005) dispõe sobre a análise técnica para emissão de outorga de direito de uso de recursos hídricos para fins de lançamento de efluentes em cursos d'água de domínio da União [86].

A Resolução CONAMA no 370 (2006) prorroga o prazo para complementação das condições e padrões de lançamento de efluentes, previsto no art. 44 da Resolução CONAMA n 357, de 17 de março de 2005 [4].

A Lei Federal 11.445 (2007) estabelece diretrizes nacionais para o saneamento básico. Considera-se saneamento básico o conjunto de serviços, infraestrutura e instalações operacionais de abastecimento de água potável (desde a captação até as ligações prediais), esgotamento sanitário (da coleta até a disposição final adequada), limpeza urbana e manejo de resíduos sólidos (da coleta até a disposição final do lixo doméstico e do lixo oriundo de limpeza de locais públicos) e drenagem e manejo das águas pluviais urbanas (do amortecimento de cheias até a disposição final destas) [87].

A Resolução CONAMA no 396 (2008) dispõe sobre a classificação e diretrizes ambientais para o enquadramento das águas subterrâneas e dá outras providências [4]. No anexo I desta resolução são definidos os padrões de qualidade para água subterrânea, dependendo da finalidade do uso, são elas, consumo humano, dessedentação de animais, irrigação e recreação.

A Resolução CONAMA 397 (2008) altera o artigo 34 da Resolução do CONAMA nํㅜ 357 de 2005, que dispõe sobre a classificação dos corpos de água e diretrizes ambientais para o seu enquadramento, bem como estabelece as condições e padrões de lançamento de efluentes. Esta alteração define novos padrões de temperatura e concentração de alguns elementos para o lançamento de efluentes [4].

A Resolução CONAMA no 410 (2009) prorroga o prazo para complementação das condições e padrões de lançamento de efluentes, previsto no art. 44 da Resolução CONAMA nํ357, e no art. 3ํ da Resolução CONAMA n 397, de 3 de abril de 2008 [4]. 
A Resolução CONAMA 430 (2011) dispõe sobre as condições e padrões de lançamento de efluentes, complementa e altera a Resolução CONAMA № 357 [4]. Esta Resolução foi abordada de forma mais detalhada no item que trata da legislação ambiental vigente (item 5.3.1 este trabalho).

\subsection{Política Nacional de Recursos Hídricos: Uma Descrição da Política}

Embora as discussões em torno das políticas ambientais no mundo terem iniciado em 1972, em Estocolmo, na primeira Conferência das Nações Unidas sobre Meio Ambiente, apenas em 1977 a água começou a ser discutida de forma mais isolada, na Conferência das Nações Unidas sobre Água, em Mar Del Plata [88] [89].

Mesmo com a criação do SEMA (Secretaria Especial do Meio Ambiente) em 1973, após a Conferência das Nações Unidas, em Estocolmo. A cidade de São Paulo, em 1991, foi a pioneira no Brasil ao criar uma Política Estadual de Recursos Hídricos, também conhecida como Lei Paulista das Águas, semelhante ao aplicado na França. Após a Conferência Internacional sobre Água e Meio Ambiente, a União criou em 1995 o Ministério do Meio Ambiente dos Recursos Hídricos e da Amazônia Legal e no dia 08 de janeiro de 1997 foi sancionada a Lei 9433 que define a Política Nacional de Recursos Hídricos e instituiu o Sistema Nacional de Gerenciamento de Recursos Hídricos [88].

\subsubsection{Objetivos da Política Nacional de Recursos Hídricos}

Somente nos anos 90 o Brasil foi marcado pelo desenvolvimento sustentável, com a aprovação da legislação que implementa a Política Nacional dos Recursos Hídricos e criação do Sistema Nacional de Gerenciamento dos Recursos Hídricos. Em 1991 foi apresentado, pelo Governo Federal ao Congresso Nacional, um projeto que tinha como proposta um esquema moderno de Gestão de Recursos Hídricos, porém com as discussões que envolviam o setor elétrico e o setor ambiental o projeto somente foi aprovado em 1997 [90]. Alguns dos principais pontos tratados nessa lei foram: a necessidade de se autorizar previamente a utilização da água (através do instrumento da outorga), o pagamento de taxas 
equivalentes ao impacto ambiental causado pelo uso (princípio do poluidorpagador), a constituição de comitês de bacia hidrográfica (os chamados parlamentos da água), adoção da bacia hidrográfica como unidade de planejamento, associada ao reconhecimento da água como bem econômico e o reconhecimento da importância de seus usos múltiplos [91, 90].

Os principais objetivos desta política são assegurar à atual e às futuras gerações disponibilidade de água, em padrões de qualidade adequados aos usos, a utilização racional e integrada dos recursos hídricos, a prevenção e a defesa contra eventos hidrológicos críticos de origem natural ou decorrentes do uso inadequado dos recursos naturais [92].

\subsubsection{Atores, Arenas e Fóruns da Política Nacional de Recursos Hídricos}

Os atores são aqueles que possuem algum interesse nos conflitos relacionados ao tema em questão, no caso, quem tem seus interesses afetados pelos conflitos e decisões relacionados ao gerenciamento dos recursos hídricos no Brasil. Esses atores agem em defesa de seus interesses nos órgãos e entidades do SINGREH (Sistema Nacional de Gerenciamento de Recursos Hídricos), são estes órgãos [93]:

- Agências de Águas de Rios de Domínio da União;

- Conselhos Estaduais de Recursos Hídricos;

- Consórcios Intermunicipais de Bacias Hidrográficas; e

- Comitês de Bacias Hidrográficas (União - Estados);

- Órgãos Estaduais, tal como, secretarias.

Estes órgãos apresentam estrutura apresentada na FIG. 3. 


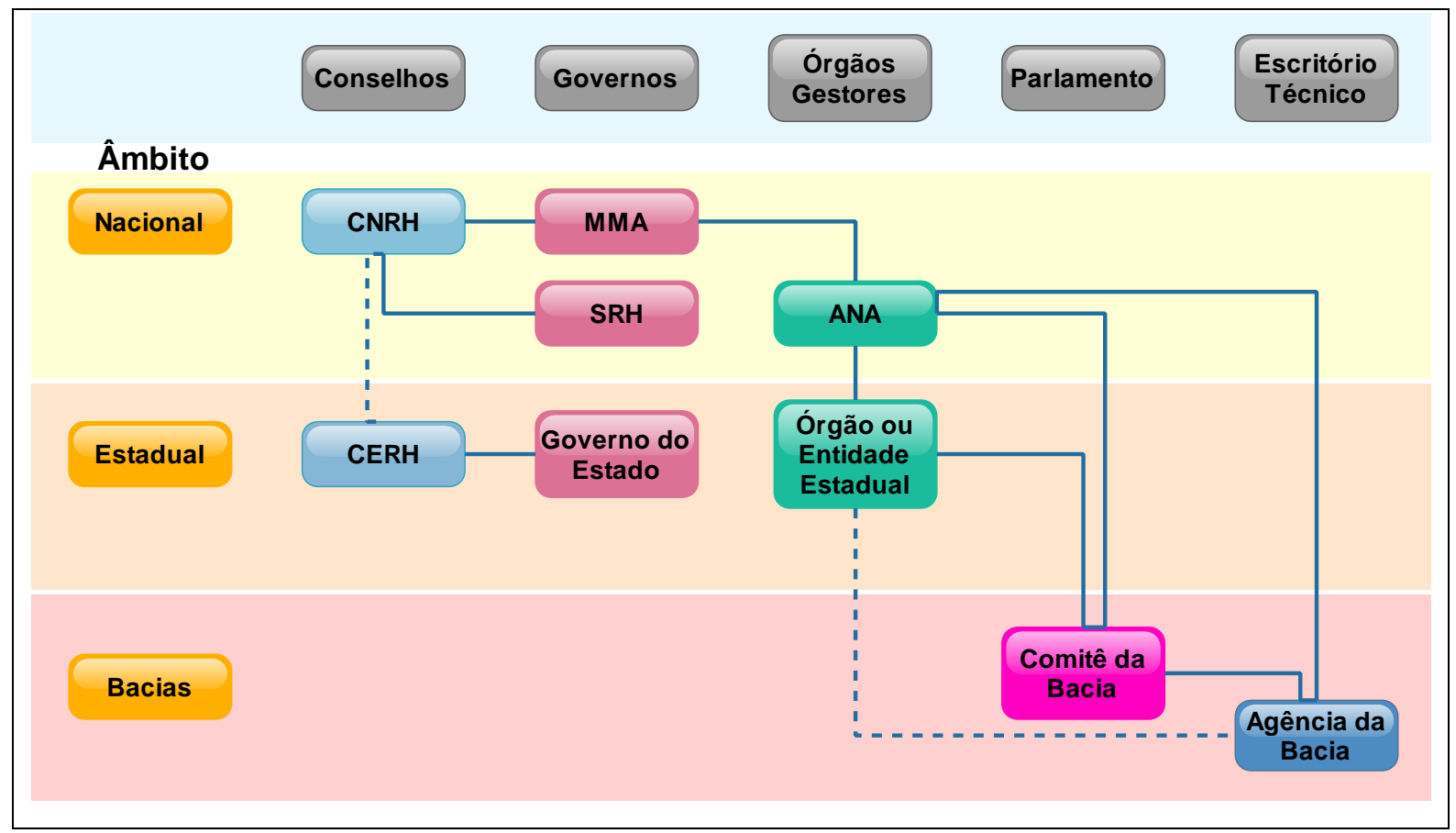

FIGURA 3: Estrutura dos colegiados do SINGREH

Fonte: NEVES, 2010 [93]

Alguns dos atores presentes nos fóruns citados acima são o poder público, usuários dos recursos hídricos (representantes de indústrias, por exemplo) e membros da sociedade civil. Os atores se apresentam nas arenas com recursos para defender seus interesses e buscar uma decisão favorável ao seu fim de uso dos recursos hídricos. Geralmente os atores estão munidos de recursos do poder, uso da capacidade política e outros recursos para influenciar o processo decisório nas arenas e fóruns, como por exemplo, um regime que pode favorecer determinados atores e não outros. E a dinâmica entre os atores pode ocorrer da seguinte maneira [93]:

- Lutas: onde o objetivo é definir a derrota de um ator com interesses opostos;

- Jogos: o objetivo é vencer, mas não eliminar o oponente, pois este pode tornar-se um aliado.

- Debates: onde o objetivo é convencer, negociar com o oponente. 
Assim os grupos de interesses podem ser eliminados das arenas, tornarem-se aliados de um grupo vencedor ou convencer que seus argumentos são os melhores para a causa defendida. Assim as decisões são tomadas.

\subsubsection{Conflitos e Tensões}

Alguns conflitos e tensões foram surgindo no decorrer da implantação da Política Nacional de Recursos Hídricos, esses conflitos ocorreram em diversos segmentos e ainda vem surgindo conforme os instrumentos da política vão se modificando, e os interesses de grupos divergentes vão sendo atendidos ou não. Pode ser citado como exemplo destes conflitos a utilização de bases na legislação ambiental para o surgimento de novas alternativas para a acumulação de capital, criando dispositivos que busquem "implementar mecanismos financeiros que complementassem e, ao mesmo tempo, criassem sinergias com a legislação ambiental existente", desta forma podemos observar a influência do desenvolvimento econômico no desenvolvimento sustentável, o que alguns autores citam como pontos opostos [91].

Podemos também observar que, da mesma forma que em algumas regiões determinadas atividades são evitadas, limitadas e até mesmo restringidas, a mesma atividade é motivada em outras regiões com menor resistência política, bem como a expansão do agronegócio em algumas regiões do Brasil, afinal tecnologias tidas como obsoletas, ainda são viáveis [91].

O processo de implantação dos comitês e instrumentos de gestão depende quase sempre de apoio financeiro e aprovação política por parte do órgão hegemônico do sistema, a Agência Nacional de Águas (ANA). Formalmente, os comitês seriam uma arena democrática e descentralizadora, mas na prática têm se constituído em mecanismos rígidos, hierarquizados e que servem aos grupos com maior força política [91], e a participação social nestes comitês é tida como marco da igualdade nas decisões, porém a desigualdade na atomização de informações é grandiosa, deste modo, sem informação a população participativa é facilmente manipulada pela apresentação de dados técnicos e outros argumentos de grupos que dispõem de informações facilmente manipuláveis [94]. 
A cobrança pelo uso da água, um dos principais instrumentos da política, ao contrário de se tornar um incentivador da conservação ambiental, da realocação de recursos, do uso racional da água, vem operando como a aprovação do processo de mercadorização da natureza, além de ter uma grande discussão em torno da cobrança por conta do acesso comum à água, as classes menos favorecidas ficam mais restringidas neste caso, e ao invés de servirem para recuperar a condição dos corpos d'água, os valores arrecadados com a cobrança, em algumas bacias, têm servido à projetos isolados [91, 94].

\subsubsection{Múltiplos Níveis de Ação}

A Política Nacional de Recursos Hídricos definiu como níveis de ação em seu artigo $3^{\circ}[88]$ :

- A gestão sistemática dos recursos hídricos, sem dissociação dos aspectos de quantidade e qualidade;

- A adequação da gestão de recursos hídricos às diversidades físicas, bióticas, demográficas, econômicas, sociais e culturais das diversas regiões do País;

- A integração da gestão de recursos hídricos com a gestão ambiental;

- A articulação do planejamento de recursos hídricos com o dos setores usuários e com os planejamentos regional, estadual e nacional;

- A articulação da gestão de recursos hídricos com a do uso do solo;

- A integração da gestão das bacias hidrográficas com a dos sistemas estuarinos e zonas costeiras.

Visando a articulação de todos os interessados nos recursos hídricos brasileiros (atores em diversas escalas), e para que uma determinada utilização da água não seja favorecida nas decisões e consequentemente impacte em outras atividades, bem como no desenvolvimento sustentável. 


\subsubsection{Papel da Sociedade Civil e do Governo}

Na Conferência realizada no Rio de Janeiro, que ocorreu em 1992, foi assinado um documento, denominado Agenda 21, onde no seu capítulo 23 é estabelecido o papel dos governos de todo país e está em destaque o papel do cidadão na defesa do meio ambiente. Dentre as bases deste capítulo encontra-se o fortalecimento da participação de todos os grupos sociais na gestão ambiental. Deve-se destacar que a sociedade, os governos e os organismos internacionais e as ONGs (Organizações Não Governamentais) devem estabelecer parcerias no desenvolvimento sustentável, e o cidadão comum deve participar das discussões públicas para a tomada de decisões, afinal também será afetado por elas. Foram definidos como meios para a participação social nas decisões, quanto ao gerenciamento dos Recursos Hídricos [95]:

- A gestão descentralizada, participativa e integrada em relação aos recursos naturais;

- A divisão das bacias hidrográfica;

- Espaços de participação da sociedade, em níveis iguais aos dos representantes do poder público.

Assim as instituições da sociedade civil passam a dividir responsabilidades com as entidades públicas e governamentais. A comunidade, organizada em entidades representativas e de defesa de interesses coletivos e difusos, passou a exercitar a sua cidadania na área ambiental e no gerenciamento dos recursos hídricos. Explicitando que com a participação social, dos governos e outros órgãos interessados é possível alcançar o desenvolvimento sustentável [95].

\subsubsection{Instrumentos}

A lei que estabelece a Política Nacional de Recursos Hídricos também definiu uma série de instrumentos envolvidos na gestão das águas com o propósito de obter melhoria dos resultados no planejamento, implantação e operacionalização dos empreendimentos que utilizam os recursos hídricos, são 
eles os Planos de Recursos Hídricos, o enquadramento dos corpos d’água em classes segundo os seus usos preponderantes, a outorga do direito de uso da água, a cobrança pelo uso da água, a compensação a municípios e os Sistemas de Informações sobre Recursos Hídricos.

Os Comitês de Bacia, que representam o fórum de decisão no âmbito de cada bacia hidrográfica constituídos por representantes dos usuários de recursos hídricos, da sociedade civil organizada e dos três níveis de governo, as Agências de Água, que servem de base de um ou mais comitês e, entre outras responsabilidades, deverão realizar os estudos necessários para a gestão dos recursos hídricos em sua área de atuação, cobrar pelo uso dos recursos hídricos e gerir os recursos oriundos dessa cobrança, elaborar o plano de recursos hídricos de sua bacia e submetê-lo à apreciação do comitê, e gerir o sistema de informação sobre recursos hídricos em sua área de atuação [90].

Como responsável por promulgar as legislações responsáveis por garantir os níveis de qualidade ambiental no Brasil temos o CONAMA (Conselho Nacional de Recursos Hídricos), e temos como exemplo a resolução CONAMA no 357 de 2005, que é a norma legal brasileira para gestão da qualidade das águas superficiais. Esta norma dispõe sobre a classificação dos corpos d'água e dá diretrizes ambientais para o seu enquadramento [4].

A Resolução CONAMA 430 (que altera e complementa a Resolução CONAMA 357/05) apresenta-se como um avanço da legislação ambiental ao se incluir orientações para análise da capacidade de suporte do corpo de água receptor para recebimento dos efluentes. Estas resoluções promulgadas pelo Conselho Nacional de Meio Ambiente podem ser tidas como exemplos de instrumentos da Política Nacional de Recursos Hídricos, pois estabelecem níveis de concentração de determinados elementos químicos que podem estar presentes em um corpo receptor, de acordo com sua classificação [4]. Os níveis estabelecidos nesta legislação são calculados a partir de dados e análises de ecotoxicidade, e pressupõem a exposição da população por longos períodos de tempo, afinal sempre é necessário considerar a magnitude, frequência e duração da exposição 
ao analito, bem como o tipo de população exposta, como mostra a divisão de dose na FIG. 4 [96].

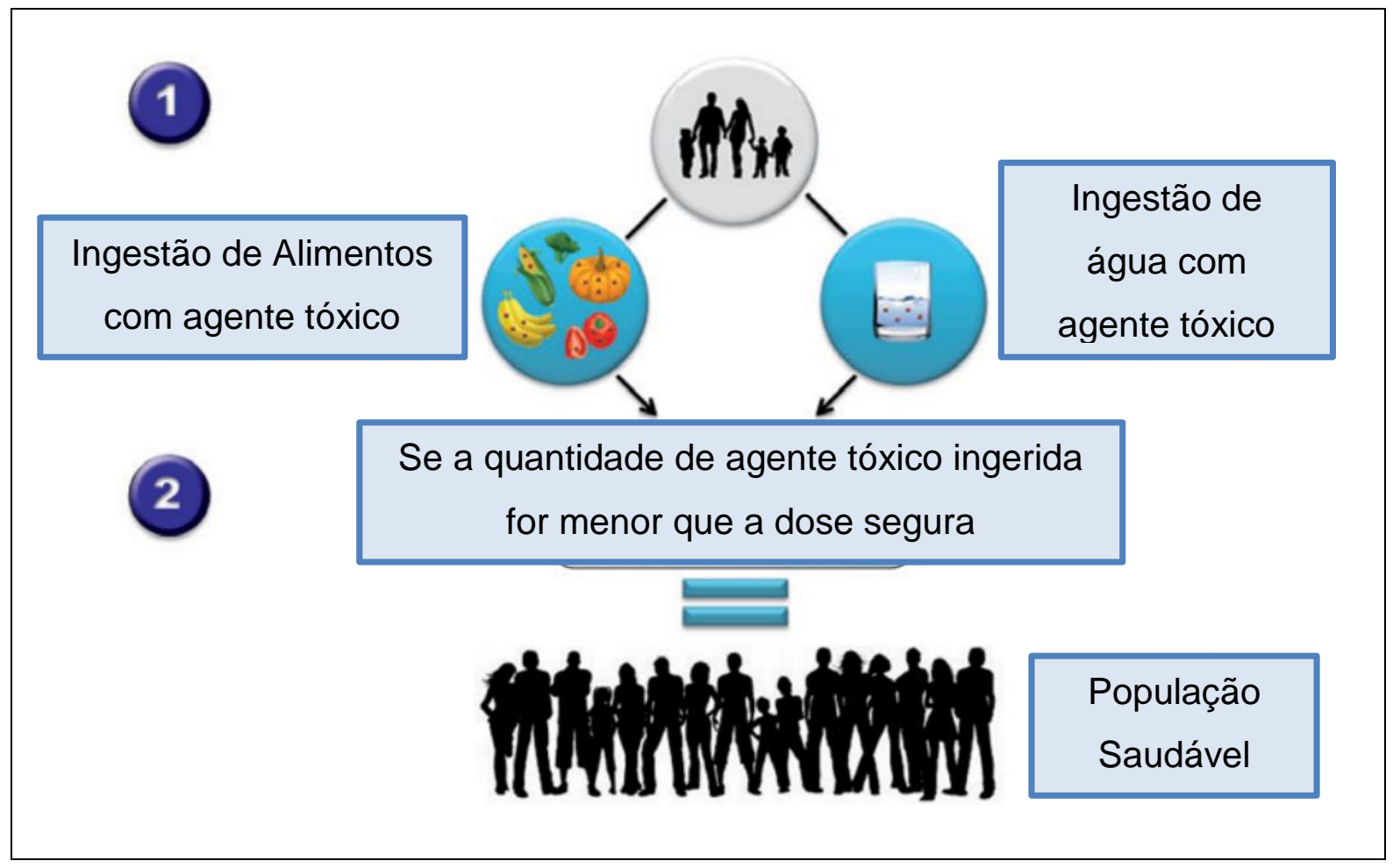

FIGURA 4: Divisão de dose entre alimentação e ingestão de água

Fonte: UMBUZEIRO, 2012 [96]

Desta forma várias técnicas são utilizadas para a análise da amostra de efluente ou água superficial. A técnica utilizada para a realização das análises deve obedecer algumas premissas, tais como: a precisão e/ou resolução do equipamento ou técnica utilizada deve estar compatível com o limite apresentado na legislação, ou seja, o limite de deteç̧ão do equipamento não pode ser maior que o limite regulamentado, e sua precisão deve acompanhar a precisão solicitada pela regulamentação. A incerteza de medição também é um parâmetro de extrema importância, afinal através deste parâmetro é possível concluir com clareza se os resultados obtidos estão dentro do normatizado ou não, como mostra a FIG. 5. Também é uma premissa da Resolução CONAMA 430 que o método analítico seja validado conforme itens descritos na norma NBR ISO/IEC 17025 [96]. 


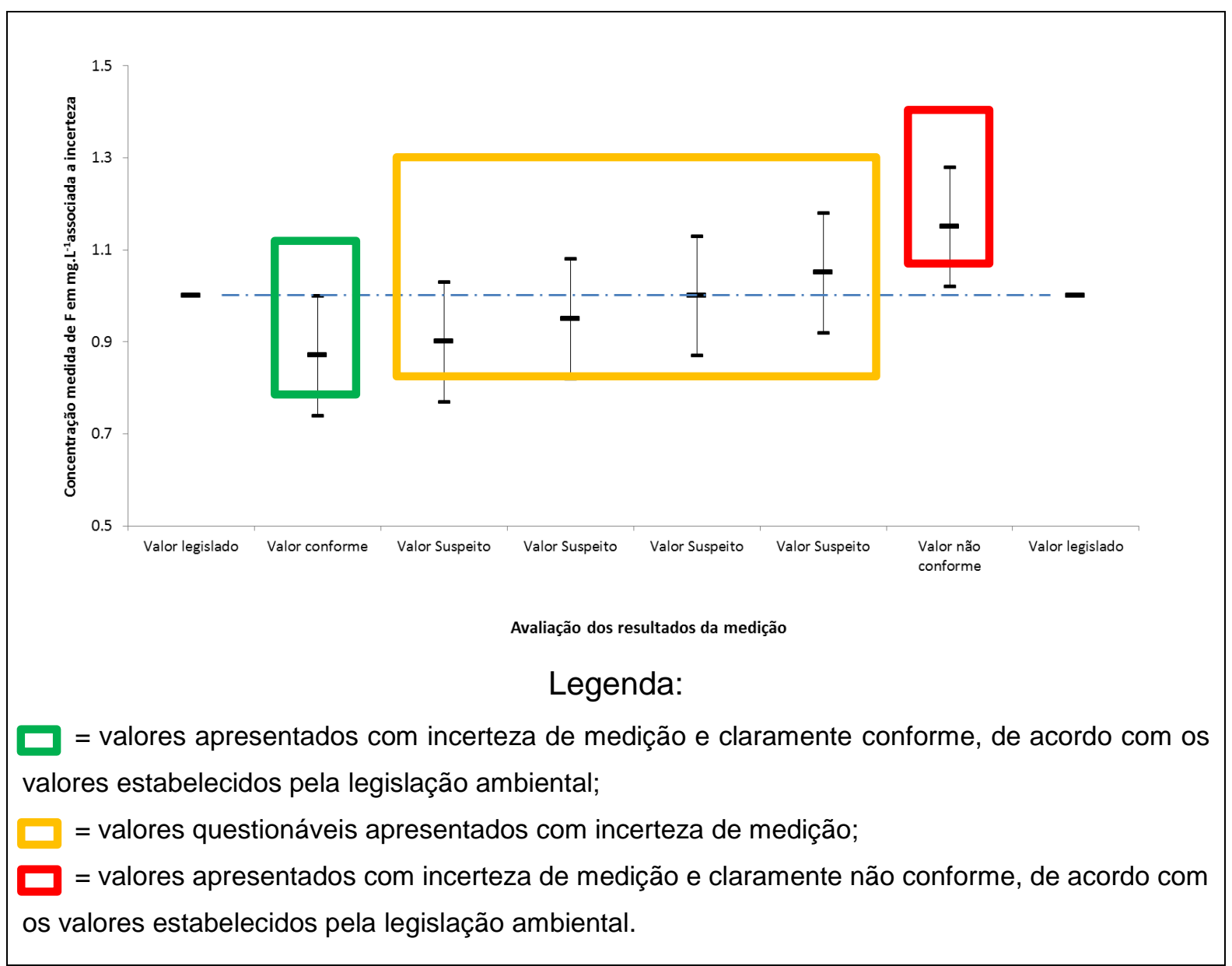

FIGURA 5: Exemplo de avaliação da conformidade de resultados

Fonte: MONTEIRO, 2011 [97]

Nos itens abaixo serão descritos os instrumentos da PNRH.

\subsubsection{Planos de Recursos Hídricos}

Os Planos de Recursos Hídricos são planos diretores que visam a fundamentação e orientação para a implementação da Política Nacional de Recursos Hídricos e a gestão dos recursos hídricos, e possuem as seguintes características [98]:

\section{Longo prazo;}

2. Horizonte de planejamento compatível com o período de implantação de seus programas e projetos; 
3. São elaborados por bacia hidrográfica, por Estado e também para o País.

\subsubsection{Enquadramentos dos recursos hídricos}

O enquadramento dos corpos d'água, por assim dizer se trata de uma classificação que permite a destinação de volumes de água de determinado padrão de qualidade a usos cuja exigência seja compatível. Esse instrumento tem como objetivo [98]:

1. Assegurar às águas qualidade compatível com os usos mais exigentes a que forem destinadas; e

2. Diminuir os custos de combate à poluição das águas, mediante ações preventivas permanentes.

As legislações ambientais estabelecem limites e parâmetros específicos, para as substâncias químicas que podem ser encontradas nos corpos de água, de modo que sua qualidade seja mantida. O CONAMA (Conselho Nacional do Meio Ambiente), segundo o Ministério do Meio Ambiente, é o órgão consultivo e deliberativo do Sistema Nacional do Meio Ambiente-SISNAMA [99].

\subsubsection{Outorga dos Direitos de Uso dos Recursos Hídricos}

O processo de outorga é um instrumento através do qual o usuário assegura, por prazo determinado, o seu direito ao uso desse recurso. A cobrança visa incentivar o uso racional e o reconhecimento de que a água é um recurso natural dotado de valor econômico [92].

\subsubsection{Sistema Nacional de Informações sobre Recursos Hídricos (SNIRH)}

O SNIRH é um banco de dados que auxilia no gerenciamento e planejamento dos recursos hídricos, e com o Sistema de Gerenciamento de Recursos Hídricos o Conselho Nacional e os Conselhos Estaduais de Recursos 
Hídricos, foram determinados como os órgãos nos pontos mais elevados na hierarquia deste sistema, aos quais cabe decidir sobre questões relevantes dessa gestão, legislação, assim como gerenciar a resolução de conflitos.

Este sistema visa coletar tratar, armazenar e recuperar informações de recursos hídricos e fatores intervenientes em sua gestão [98].

\subsubsection{Cobrança pelo Uso da Água}

A cobrança pelo uso de recursos hídricos visa principalmente: reconhecer a água como bem econômico e dar ao usuário uma indicação de seu real valor; incentivar a racionalização do uso da água; obter recursos financeiros para o financiamento dos programas e intervenções contemplados nos planos de recursos hídricos [98].

\subsection{Legislação Ambiental Vigente}

\subsubsection{Legislação Federal: Resolução CONAMA 430/11}

A Resolução CONAMA 430 apresenta-se como um avanço da legislação ambiental ao se incluir orientações para análise da capacidade de suporte do corpo d'água para recebimento dos efluentes. Além disso, foi dado um prazo de três anos na deliberação para que os empreendimentos se adéquem a esses novos padrões. Esta atualização também exige que os laboratórios e métodos de coleta das amostras sejam acreditados pelo INMETRO (Instituto Nacional de Metrologia, Qualidade e Tecnologia) ou órgão equivalente [4].

De acordo com o Artigo 16 desta Resolução, para que os efluentes possam ser lançados em um determinado corpo receptor devem obedecer a padrões de $\mathrm{pH}$, temperatura, sólidos sedimentáveis, óleos e graxas, parâmetros inorgânicos e parâmetros orgânicos, e caso o efluente possua em sua composição elementos não especificados nesta resolução o responsável deverá solicitar autorização ao órgão competente (como a CETESB no estado de São Paulo) [4]. 
Na TAB. 1 estão listados os Valores Máximos Permitidos estabelecidos por esta Resolução para os elementos estudados neste trabalho, estes valores estão especificados na Tabela I do Art. 16 Seção II da Resolução CONAMA 430.

TABELA 1: VMPs dos metais e semimetais estudados, definidos na Resolução CONAMA 430/11

\begin{tabular}{cc}
\hline Parâmetro Inorgânico & VMP art. $\mathbf{1 8}\left(\mathbf{m g} \cdot \mathbf{L}^{-\mathbf{1}}\right)$ \\
\hline Cádmio total & 0,2 \\
Zinco total & 5,0 \\
Manganês dissolvido & 1,0 \\
Níquel total & 2,0 \\
Boro total & 5,0 \\
Ferro dissolvido & 15,0 \\
Bário total & 5,0 \\
Chumbo total & 0,5 \\
Cobre dissolvido & 1,0 \\
Crômio hexavalente & 0,1 \\
Crômio trivalente & 1,0 \\
Estanho total & 4,0 \\
\hline
\end{tabular}

Fonte: BRASIL, 2012 [4]

\subsubsection{Legislação Estadual de São Paulo: D.E. 8.468 e D.E. 15425}

O Decreto Estadual 8.468 foi instituído em 1976 e dispões sobre o controle da poluição do meio ambiente e dá outras providências. Define também como competência da CETESB (Companhia Ambiental de São Paulo), na qualidade de órgão delegado do Governo do Estado de São Paulo, a aplicação desta norma [8].

Quando alterado pelo Decreto 15.425 em 1980, o artigo 18 do Decreto Estadual 8.468 foi modificado de lançamento de qualquer fonte poluidora para regime de lançamento com vazão máxima de até 1,5 vezes a vazão média diária de lançamento, e o Artigo 19 A para os efluentes de qualquer fonte poluidora a serem lançados em sistema de esgotos, provido de tratamento com capacidade e 
de tipo adequados. Mas os VMPs para cada um dos parâmetros foram mantidos [9].

O Artigo 18 deste decreto define os VMPs para os efluentes a serem lançados, direta ou indiretamente, nas coleções de água, e o Artigo 19 A do mesmo decreto, define VMPs para os efluentes de qualquer fonte poluidora a serem lançados em sistema de esgotos, provido de tratamento com capacidade e tipo adequados. Os VMPs definidos por estes dois artigos, para os elementos estudados neste trabalho, seguem na TAB. 2 [8].

TABELA 2: VMPs dos metais e semimetais estudados, definidos no DE 8,468/76

\begin{tabular}{ccc}
\hline Parâmetro Inorgânico & VMP art. 18 (mg. $\left.\mathbf{L}^{-1}\right)$ & VMP art. 19 A (mg.L-1) \\
\hline Cádmio & 0,2 & 1,5 \\
Zinco & 5,0 & 5,0 \\
Manganês solúvel $\left(\mathrm{Mn}^{2+}\right)$ & 1,0 & - \\
Níquel & 2,0 & 2,0 \\
Boro & 5,0 & - \\
Ferro solúvel $\left(\mathrm{Fe}^{2+}\right)$ & 15,0 & 15,0 \\
Bário & 5,0 & - \\
Chumbo & 0,5 & 1,5 \\
Cobre & 1,0 & 1,5 \\
Crômio hexavalente & 0,1 & 1,5 \\
Crômio total & 5,0 & 5,0 \\
Estanho & 4,0 & 4,0
\end{tabular}

Obs.: A soma da concentração dos elementos As, Cd, Pb, Cu, Hg, Ag, Se, Cr - total, Zn, Sn e Ni não pode ultrapassar $5,0 \mathrm{mg} \cdot \mathrm{L}^{-1}$. 


\section{TÉCNICA ANALÍTICA}

A técnica analítica utilizada para determinação dos metais em efluente no desenvolvimento deste trabalho é a espectrometria de emissão óptica com plasma acoplado indutivamente. Técnica que permite a quantificação de elementos (metais, semimetais e terras raras) em diversos tipos de amostras. Esta técnica foi escolhida por ser uma técnica conceituada na análise de metais em amostras ambientais, bem como em diversas outras matrizes. Outras particularidades desta técnica serão abordadas no decorrer deste capítulo.

\subsection{Espectrometria}

A espectrometria se refere à medida da intensidade das radiações com um detector fotoelétrico ou outro equipamento eletrônico. A maioria dos métodos espectrométricos se baseiam em radiação eletromagnética, pois é um tipo de energia que pode ter várias formas de leitura, como luz e calor. Métodos espectrométricos que empregam não somente a leitura na região do visível, mas também a região do ultravioleta e infravermelho (vide regiões do espectro na FIG. 6) são chamados de métodos ópticos. Este termo vem da característica comum de instrumentos que trabalham com três regiões espectrais e das similaridades na maneira em que estas três radiações interagem com a matéria [16]. 


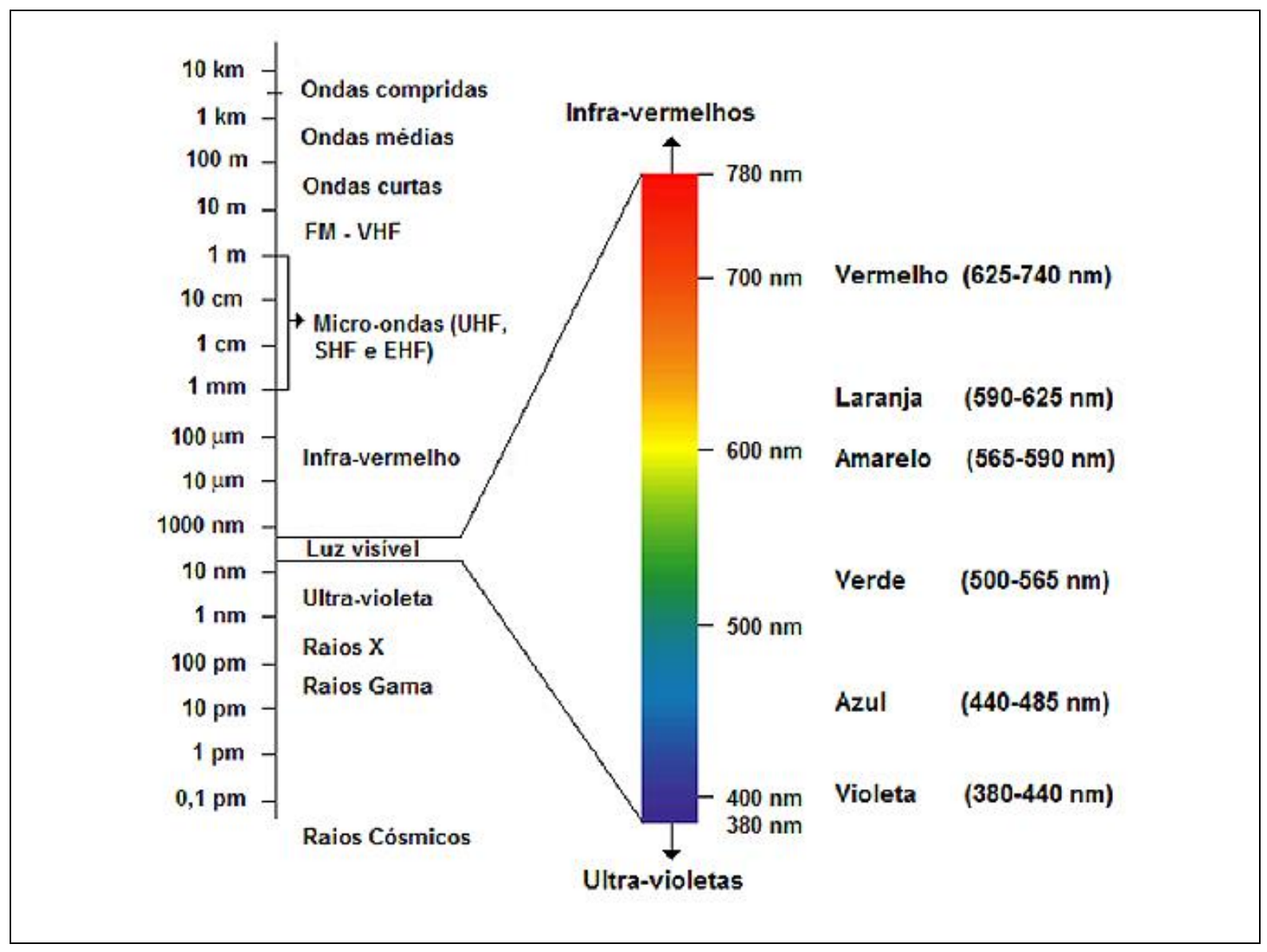

FIGURA 6: Regiões do espectro eletromagnético

Fonte: ATKINS, 2006 [100]

Métodos espectrométricos também podem ser caracterizados pelo método de detecção dos íons, podem ser de absorção ou emissão, os métodos de absorção são aqueles que utilizam uma lâmpada para que determinados elementos em seu estado fundamental, que absorvem energia em um comprimento de onda pré-determinado, sejam detectados. Os métodos de emissão são aqueles que utilizam uma fonte de excitação para os analitos e detectam os fótons característicos que os elementos emitem quando retornam para o estado fundamental [11].

Existem também diferenças entre espectroscopia atômica e molecular, ao contrário das moléculas em solução, os átomos possuem bandas finas, também conhecidas como raias (de $10^{-3}$ a $10^{-2} \mathrm{~nm}$ ), o que dificulta a sobreposição dos espectros de elementos diferentes, possibilitando assim a análise multielementar [101] [102]. 


\subsection{Espectrometria de Emissão Óptica com Fonte de Plasma de Acoplado Indutivamente - Plasma de Argônio (ICP-OES)}

O ICP-OES é uma técnica baseada na emissão de fótons, oriundos de íons excitados pelo plasma, que é gerado por uma bobina de radiofrequência [15]. Após a inserção da amostra no equipamento esta é convertida em um aerossol que é direcionado para o plasma, onde os átomos são convertidos em íons e depois são elevados para um nível excitado. Estas espécies quando retornam ao estado fundamental emitem fótons, que são característicos de cada espécie química, bem como a quantidade de fótons é proporcional à concentração do analito. Uma porção destes fótons é coletada com uma lente ou espelhos côncavos, que formam uma imagem na abertura de um equipamento de seleção de comprimentos de onda. Estes comprimentos de onda são convertidos em sinais elétricos por um fotodetector, e em um computador o sinal é amplificado e processado [15].

O ICP-OES opera com emissão de radiação eletromagnética na região do visível e ultravioleta do espectro, e a técnica de análise é baseada na excitação do analito pelo plasma de argônio. Os elementos presentes na amostra produzem fótons em diversos comprimentos de onda, mas é possível definir o comprimento de onda desejado para a determinação de cada analito. Através de uma relação estabelecida com um padrão de referência e a intensidade de energia detectada no comprimento de onda indicado, é possível determinar a concentração do analito na amostra. Esta relação é construída através das curvas analíticas [14].

Amostras líquidas ou gasosas podem ser analisadas com esta técnica, enquanto amostras sólidas necessitam de tratamento prévio (como digestão ácida ou extração) para a liberação do analito.

A espectrometria de emissão óptica com fonte de plasma acoplado indutivamente foi desenvolvida por Fassel et al. na Universidade Estadual de lowa, no Estados Unidos, e por Greenfield et al. no Reino Unido em meados dos anos 60. O primeiro equipamento foi comercializado em 1974. Atualmente não é somente a fonte mais popular de espectrometria de emissão óptica, mas também é uma 
excelente fonte de íons para técnicas como a espectrometria de massas com plasma acoplado indutivamente (ICP-MS) [15].

Esta técnica é muito utilizada para a determinação de metais em diferentes matrizes por apresentar muitas vantagens, quando comparada às demais técnicas espectrométricas, como eficiente ionização ou excitação dos elementos (dada pelas altas temperaturas alcançadas no plasma), pela possibilidade de realizar análises multielementares, por apresentar alta sensibilidade e possibilitar a análise de uma ampla faixa de concentrações, por conta de sua linearidade característica.

O ICP-OES possui a capacidade de alcançar altíssimas temperaturas e possui uma atmosfera inerte, o que diminui a ocorrência de efeitos da matriz, além de possibilitar a determinação de até 70 elementos simultaneamente. Quando interferências espectrais ocorrem é possível corrigi-las. Quando há disponibilidade de altos volumes de amostra é possível alcançar limites de detecção considerados baixos (chegando a determinar ppb), dependendo da aplicação e também do analito, por exemplo, para a análise de alguns metais em efluente é possível alcançar limites de detecção bem mais baixos que os valores determinados pela legislação ambiental brasileira, o que a torna uma técnica muito recomendada [15, 103].

Por conta das altas temperaturas alcançadas no plasma, esta técnica permite a análise de uma grande faixa de metais, até mesmo metais que formam óxidos refratários, e também elementos que possuem alta energia de dissociação, além de possibilitar a detecção de elementos maiores, menores e traços [101]. Por possuir uma grande faixa linear de trabalho e baixa vulnerabilidade a interferências é uma técnica consagrada em aplicações ambientais, estas características também conferem facilidade no processo de calibração do equipamento utilizado [14]. A TAB. 3 apresenta algumas qualidades e limitações da técnica. 
TABELA 3: Qualidades e limitações da técnica ICP-OES

\begin{tabular}{cc}
\hline Qualidade & Limitações \\
\hline Análise multielementar & Interferências espectrais \\
Baixos limites de detecção & Efeitos de espécies na matriz \\
Baixa interferência da matriz & Efeitos do solvente da matriz \\
Grande faixa linear & Dificuldade de analisar sólidos não \\
Alta precisão & dissolvidos \\
Aplicável para análises de gases e & Precisão e Limite de detecção podem \\
líquidos & ser muito altos para determinadas \\
& aplicações
\end{tabular}

Fonte: OLESIK, 1991 [103]

As vantagens e méritos dessa técnica analítica incluem a quantidade de elementos que podem ser determinados em níveis de concentração abaixo de $1 \mathrm{mg} \cdot \mathrm{L}^{-1}$, seletividade, reprodutibilidade, estabilidade a longo prazo, precisão e exatidão. Não podem ser determinados via ICP-OES elementos que são encontrados como contaminante em argônio (como carbono oriundo do $\mathrm{CO}_{2}$ ), constituintes do solvente da amostra $(\mathrm{C}, \mathrm{O}, \mathrm{H}$ normalmente) ou contaminantes da atmosfera (como N). Elementos que necessitam de alta energia de excitação, como os halogênios podem ser determinados, porém com limites de detecção mais altos. Também podem ser determinados por esta técnica elementos radioativos [15].

\subsection{Emissão de Radiação Eletromagnética}

A radiação eletromagnética é produzida quando partículas excitadas (íons, moléculas ou átomos) vão para um estado energético mais baixo (estado fundamental), liberando a energia excedente através da emissão de fótons (conforme FIG. 7). A excitação se dá através de vários meios, bombardeamento com elétrons, exposição á correntes elétricas ou pelo calor de chamas, entre outras formas [16]. 
Em alguns casos o elétron excitado retorna ao estado fundamental em mais de uma etapa, ou seja, em níveis intermediários de emissão. Com uma fonte de excitação altamente energética, diversos elétrons (não somente o mais externo) podem ser excitados em diferentes níveis (dependendo do elemento), e a emissão de radiação resultante pode conter até mais de milhares de discretos e reprodutíveis comprimentos de onda. Geralmente na região do ultravioleta e visível [104].

A radiação emitida por uma espécie excitada é comumente chamada de emissão espectral, que normalmente tem o formato de um pico da intensidade relativa da radiação emitida, como uma função do comprimento de onda ou frequência [16].

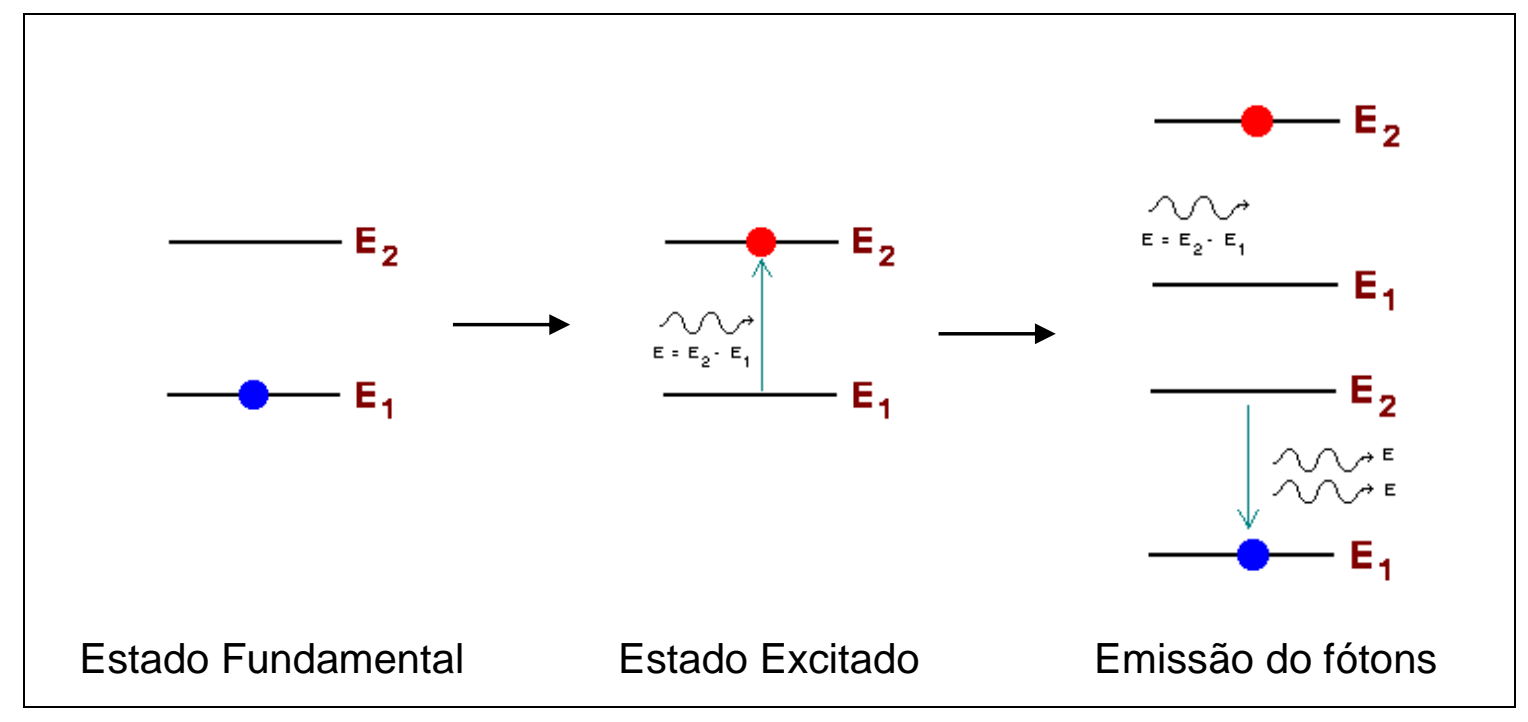

FIGURA 7: Processo de emissão de fótons

Fonte: Universidade Federal do Ceará, 2014 [105]

\subsection{Linhas Espectrais}

As linhas espectrais ocorrem quando as partículas emissoras de radiação são partículas atômicas individuais. Estas produzem emissões na região do ultravioleta ou visível e são bem separadas. Estas partículas se comportam de modo independente umas das outras, então o espectro consiste de uma série de linhas nítidas com largura de aproximadamente $10^{-4} \AA$ [16]. 


\subsection{Interferências}

A interferência é qualquer efeito que possa modificar o sinal usado para quantificação do elemento, enquanto sua concentração é constante. Esta técnica, dentre as técnicas de espectrometria, possui a fonte de excitação que oferece menos interferências. O plasma de argônio é considerado inerte, se comparado à reatividade da chama. Além de proporcionar baixas interferências da matriz, por sua alta temperatura. Algumas interferências podem ocorrer, mas ajustes como aumento da energia de radiofrequência ou ajustes do fluxo interno de argônio podem ser utilizados para reduzir as interferências [102].

Existem tipos diferentes de interferências que podem ocorrer na espectrometria. Neste trabalho serão abordadas brevemente as mais comuns, são elas química e espectral [102].

Interferências químicas são causadas por constituintes da amostra que modifiquem a atomização do analito [102]. Um tipo de interferência química que pode ocorrer nesta técnica é o chamado efeito dos elementos facilmente ionizáveis, que são aqueles elementos com menor energia de ionização, como os metais alcalinos. Alta concentração destes elementos pode suprimir ou amplificar o sinal de emissão, dependendo das espécies a serem analisadas [15].

A interferência mais comum nesta técnica é a interferência espectral, por conta da natureza multielementar da técnica, e é causada pela sobreposição do sinal do analito por sinais de outros componentes da amostra, geralmente os espectros podem ser afetados por amostras muito concentradas ou muito complexas. Neste caso correções no sinal de fundo ou mudanças no comprimento de onda de leitura dos elementos desejados pode reduzir a ocorrência destas interferências [102].

Estas interferências podem ser categorizadas da seguinte maneira: deslocamento simples do sinal de fundo, deslocamento do sinal de fundo com declive, sobreposição espectral direta e deslocamento de fundo complexo. Estas interferências têm causas e soluções específicas, mas para a correção destes 
desvios podem ser necessárias ações como a escolha de outra linha espectral onde a interferência não ocorra, diluição e/ou adaptação da amostra, além do acompanhamento das condições de ensaio com análise de padrões de verificação e branco [15].

Para evitar interferências da matriz na análise podem ser utilizadas técnicas para a redução de efeitos, como a utilização de supressores de ionização para a determinação de elementos muito ionizáveis, como o potássio, por exemplo e também pode ser utilizado o método de adição-padrão [101].

\subsection{Sistemas da Técnica Espectrometria de Emissão Óptica com Fonte de Plasma}

Os espectrômetros de emissão óptica são formados por um sistema de inserção da amostra, um sistema de excitação do analito, e um sistema de detecção. Para a análise via espectrometria é de extrema importância o sistema de ionização ou excitação da amostra, que pode ter diferentes fontes, cada uma com suas vantagens, desvantagens e peculiaridades. Neste trabalho o foco será direcionado para o plasma como fonte de excitação (Plasma acoplado indutivamente ou do Inglês Inductively Coupled Plasma - ICP), pois é característica do equipamento utilizado para a determinação experimental neste trabalho. Na FIG. 8 é possível visualizar um esquema que demonstra cada um dos sistemas do equipamento de ICP-OES, cada um destes sistemas será melhor descrito no decorrer deste capítulo. 


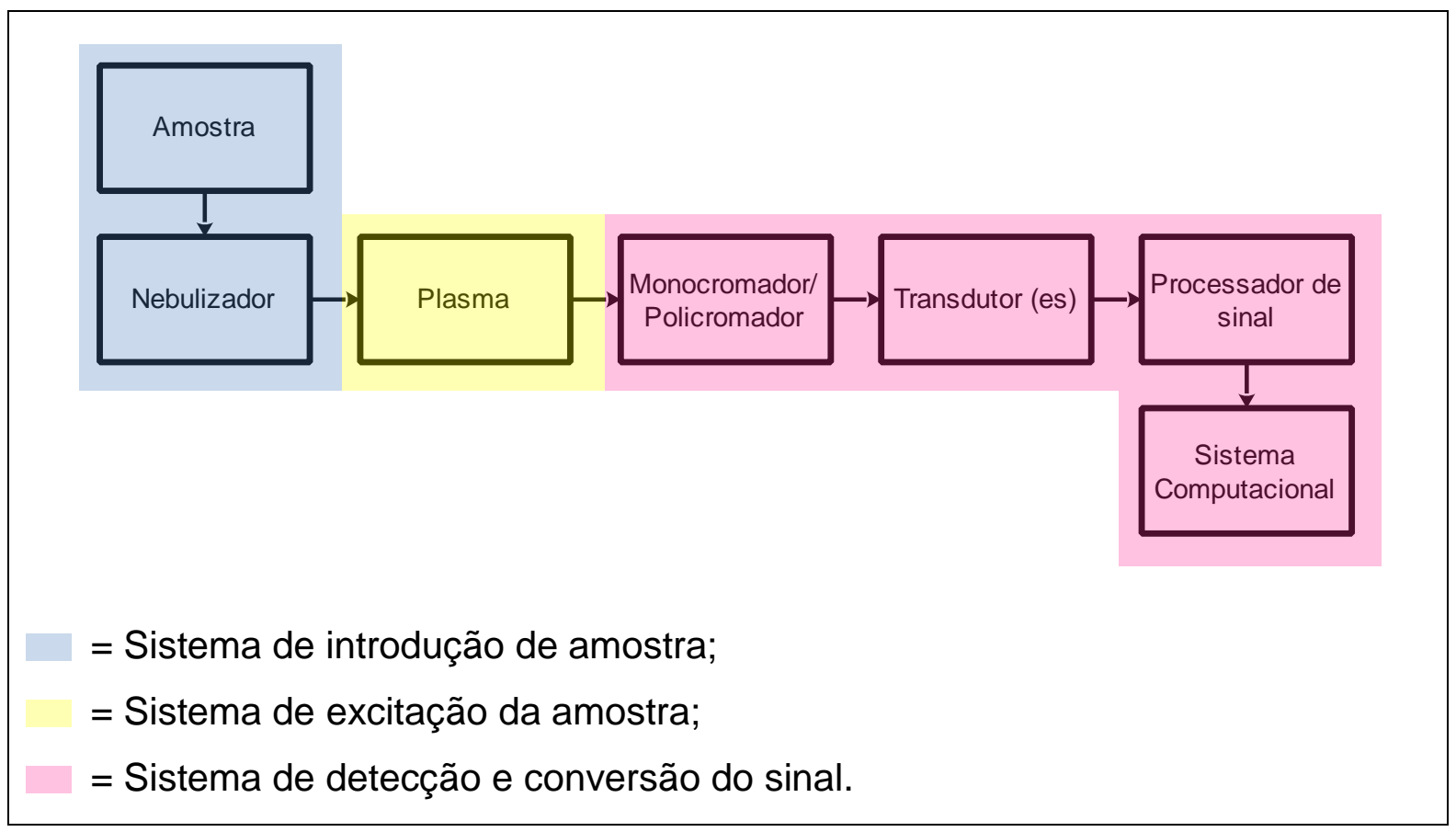

FIGURA 8: Diagrama de blocos do equipamento de ICP-OES

\subsubsection{Introdução da Amostra}

O sistema de introdução da amostra é utilizado para transportar a amostra no canal central do ICP como vapor ou aerossol de gotículas finas. Geralmente um sistema eficiente de introdução de amostra deve ser tolerante a amostras complexas, transportar pequenas quantidades de amostra, ser estável e reprodutível, ser fácil de manusear e ter baixo custo [15].

Em um sistema de ICP-OES a amostra é levada até a tocha pelo fluxo de argônio, passando pelo tubo de quartzo central. Existem diversos tipos de sistemas de inserção de amostra, porém normalmente a amostra é levada para a tocha, em forma de pequenas gotículas, por um sistema de nebulização, conforme mostrado na FIG. 9 [16]. 


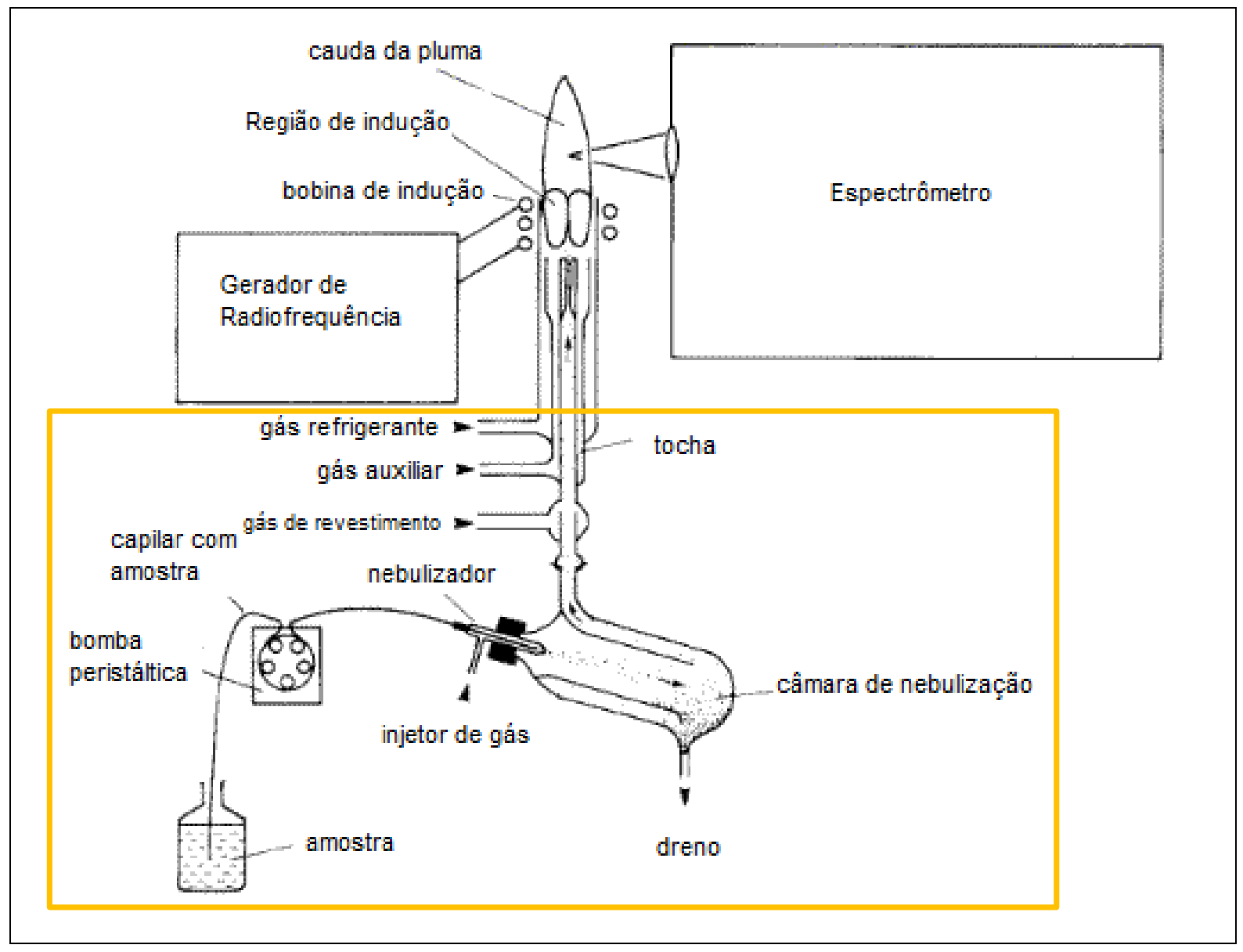

FIGURA 9: Sistema de introdução de amostra por nebulização

Fonte: WINGE, 1989 [106]

Os nebulizadores são o meio mais utilizado para a introdução de soluções em ICP-OES. Com um nebulizador a solução é convertida em um aerossol e transportada até o plasma. Como somente pequenas gotículas geradas pelo aerossol podem chegar até o plasma, há uma câmara de nebulização entre o nebulizador e o plasma, assim as gotículas maiores são removidas do aerossol e pequenos pulsos gerados pelo processo de nebulização são amortecidos. Embora com a utilização de nebulizadores pneumáticos apenas $5 \%$ da amostra atinja 0 plasma, o resto da amostra é drenado na câmara de nebulização, estes ainda são muito utilizados, pela conveniência de seu uso, razoável estabilidade e facilidade de uso. Desta forma a eficiência no transporte da amostra somente é um problema quando a quantidade de amostra é extremamente limitada e/ou a quantificação será realizada próximo ao limite de detecção [15]. Na FIG. 10 é possível ver um modelo de nebulizador também muito utilizado. O seu funcionamento consiste na entrada de amostra no nebulizador e passagem de gás, normalmente argônio, pelo braço 
lateral, onde o gás nebulizador flui por meio de uma abertura que envolve concentricamente o capilar, o que gera uma pressão reduzida na ponta, e consequentemente a aspiração da amostra. A alta velocidade do gás na ponta dispersa a solução na forma de um jato gasoso, spray ou névoa de gotículas de diversos tamanhos. Estas gotículas passam pela câmara de ionização, onde as gotículas maiores são descartadas e as menores são levadas pelo fluxo de gás até o plasma.

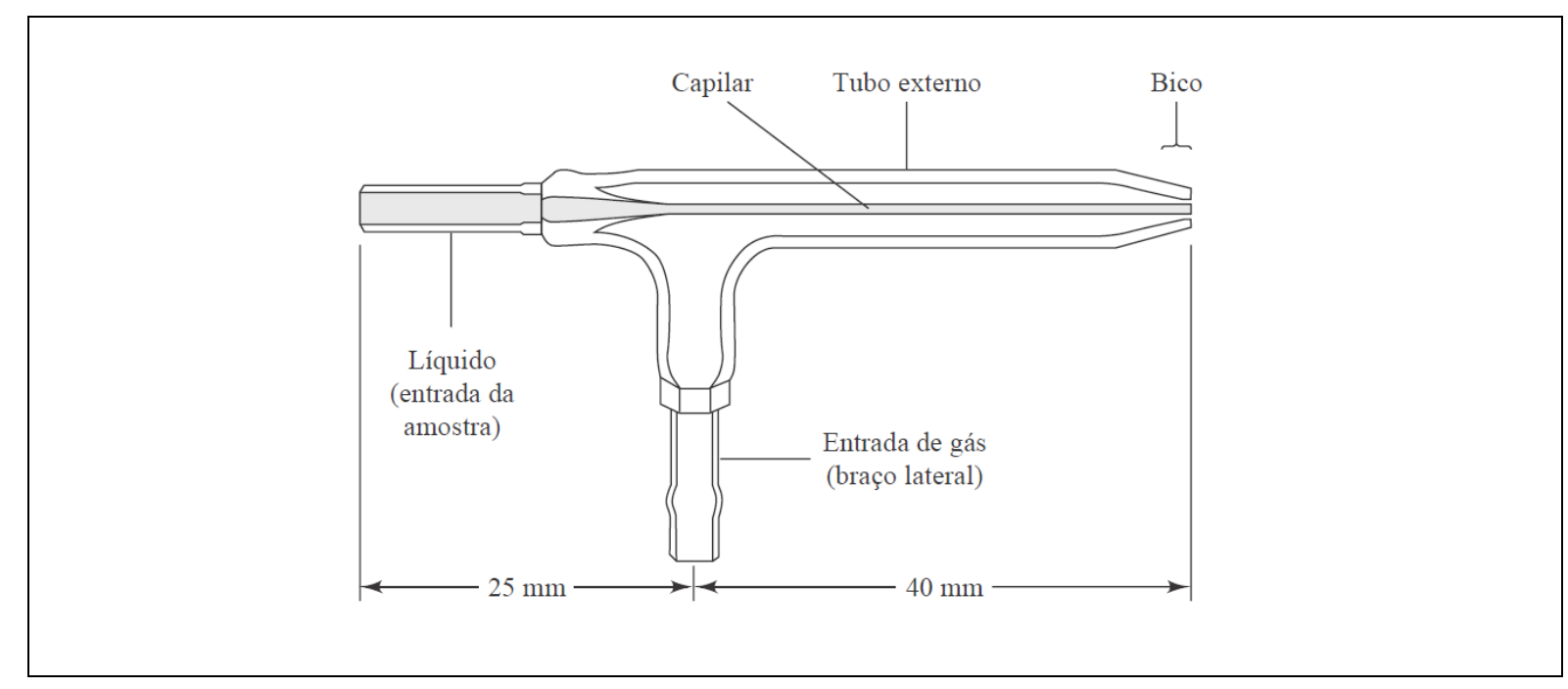

FIGURA 10: Nebulizador Meinhard

Fonte: SKOOG, 1998 [16]

\subsubsection{Atomização e Excitação do Analito}

Em um sistema de ICP-OES a excitação da amostra é realizada através do plasma. O plasma pode atingir diversas temperaturas (entre 4000 e $10000 \mathrm{~K}$ ) dependendo da região, como visto na FIG. 11. O plasma permite uma excitação ou ionização muito eficiente por conta desta alta temperatura atingida, o que corresponde a aproximadamente duas ou três vezes mais do que a maior temperatura atingida em sistemas de chama, que utilizam como combustíveis acetileno, oxido nitroso entre outros. Desta forma, a excitação é mais completa além da quase inexistente probabilidade de interferências causadas pelo processo de excitação, o que pode-se atribuir à grande concentração de elétrons oriundos da ionização do argônio e não da excitação da amostra [16]. 
O plasma possui diversas vantagens, a atomização ocorre em uma atmosfera inerte, o que permite o aumento da vida útil do analito, sem formar óxidos, na secção transversal do plasma a temperatura é considerada estável, assim efeitos como a auto absorção (a alta concentração de elementos mais externos que absorvem radiação e diminuem a eficiência de excitação) e auto reversão não são encontrados. E umas das principais características do uso do plasma para as técnicas analíticas, é a observação de uma grande gama de curvas analíticas lineares, em diversas magnitudes, o que é muito bem visto do ponto de vista metrológico e também permite uma grande faixa de trabalho de acordo com a aplicação da técnica [16].

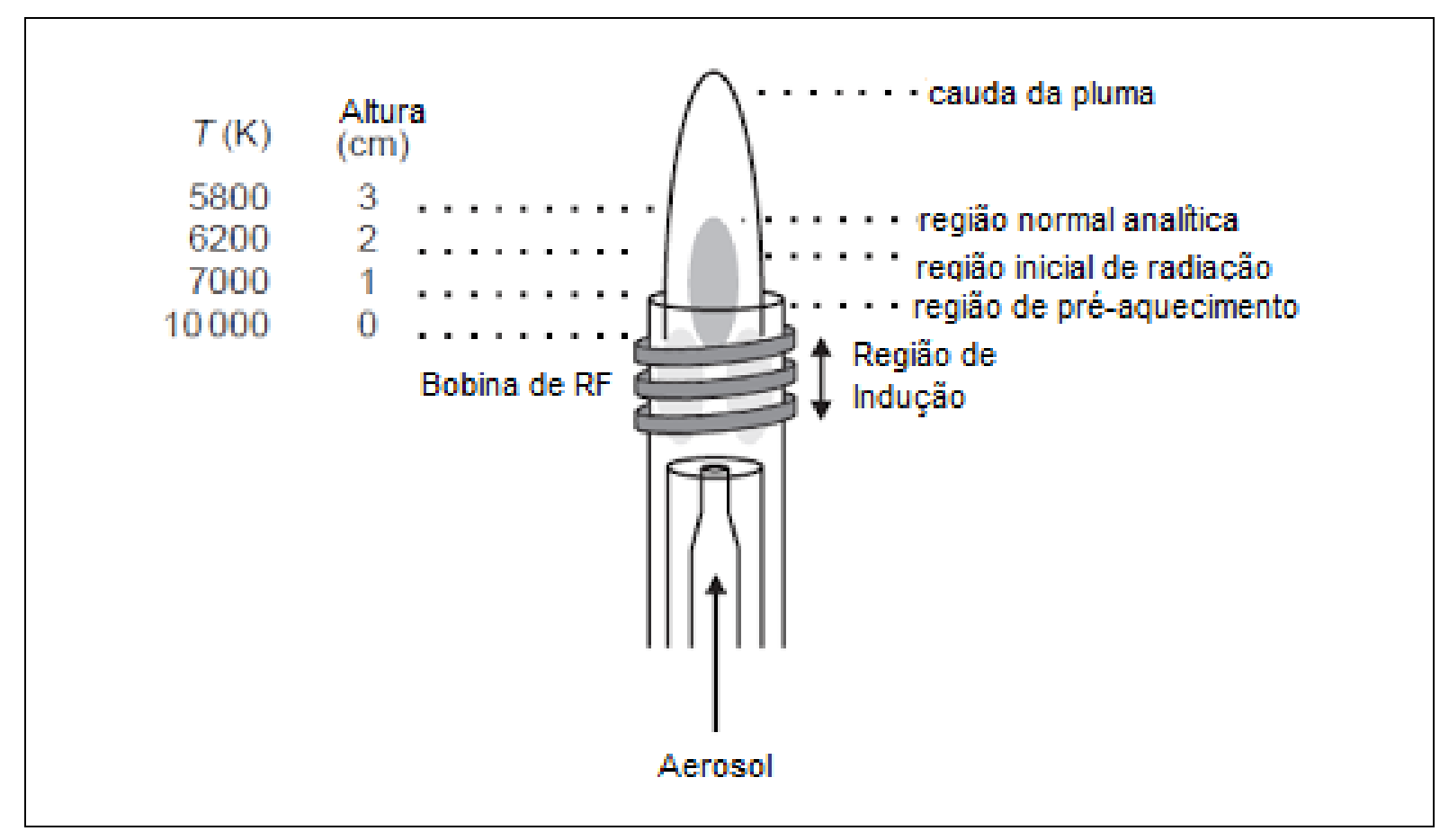

FIGURA 11: Temperaturas em diversas regiões do plasma

Fonte: KUMAR, 2013 [107]

\subsubsection{Plasma Acoplado Indutivamente (Plasma de Argônio)}

Por definição, plasma é uma mistura gasosa de condução elétrica, contendo alta concentração de cátions e ânions. Para o plasma de argônio (Ar), comumente aplicado à técnica de emissão óptica, os íons e elétrons do argônio são as principais espécies condutoras. Os íons de argônio, uma vez formados em um plasma, são capazes de absorver energia suficiente de uma fonte externa, de modo 
a atingir uma temperatura alta suficiente para que o plasma seja mantido, temperaturas de até $10000 \mathrm{~K}$ são encontradas através da colisão com átomos [16].

Na FIG. 12 podemos ver um esquema de uma tocha, usada em um sistema de plasma acoplado de argônio. A tocha consiste em três tubos de quartzo concêntricos, são eles o externo, intermediário e o interno, por onde flui o gás argônio. No topo deste tubo há uma bobina de indução de cobre, com sistema de resfriamento, esta bobina é alimentada por um gerador de radiofrequência [16].

A potência da radiofrequência é aplicada à bobina de carregamento e uma corrente alternada dentro da bobina, em proporção correspondente na frequência do gerador de radiofrequência, é gerada. A oscilação da corrente em alta frequência causa a mesma oscilação de alta frequência nos campos magnéticos e elétricos a serem criados no topo da tocha. Com o fluxo de argônio pela tocha uma faísca gerada pela bobina tesla é utilizada para produzir elétrons e íons no gás de argônio na região interna da bobina de carregamento, estes íons são acelerados pelo campo magnético, que colidem com outros átomos de argônio, causando outras ionizações em cadeia. Este processo continua até a formação de uma muita intensa, brilhante, e de alta temperatura tocha de plasma. Fornecendo energia para o plasma por colisão induzida por radiofrequência, conhecida como acoplamento induzido, portanto o plasma é chamado Plasma Acoplado Indutivamente. O plasma é mantido dentro da tocha enquanto a energia da radiofrequência for aplicada [15]. Outro esquema da tocha pode ser visto na FIG. 13 


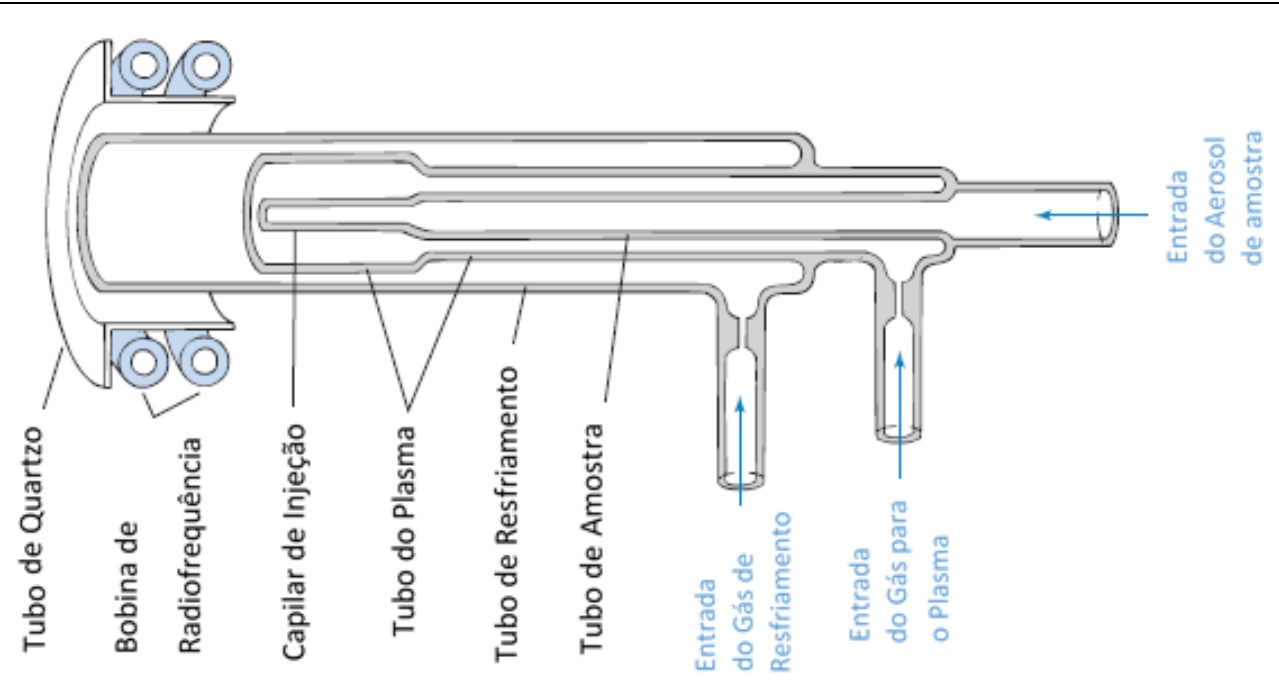

FIGURA 12: Tocha do sistema de ICP

Fonte: SKOOG, 1998 [16]

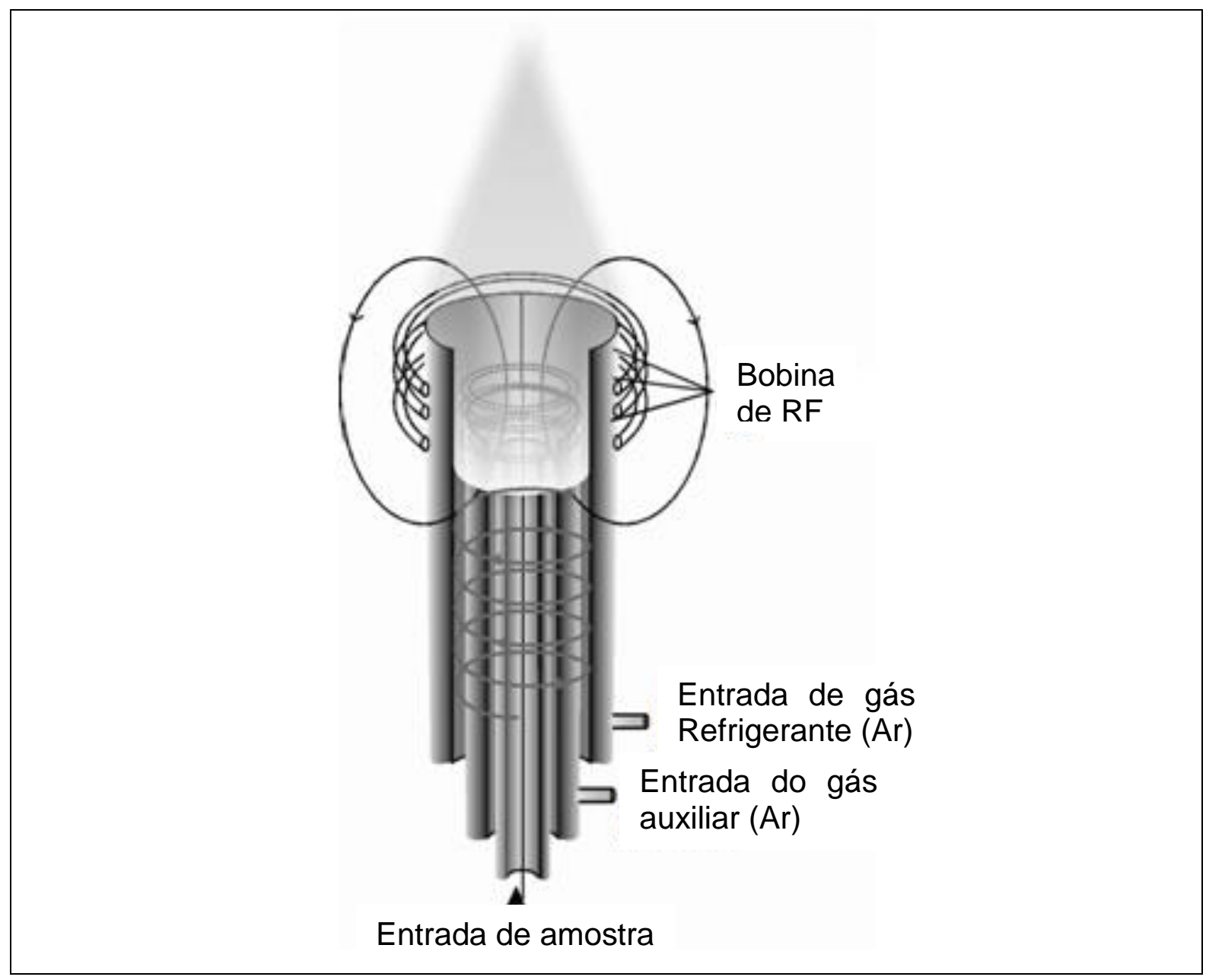

FIGURA 13: Esquema da tocha

Fonte: HARRIS, 2011 [101] 
O fluxo de argônio externo sustenta a alta temperatura do plasma, além de posicionar o plasma em relação à parede externa da tocha e a bobina de indução, prevenindo o derretimento das paredes da tocha e facilitando a observação dos sinais de emissão. O fluxo de argônio interno entra no canal central do plasma e auxilia na sustentação do seu formato. O fluxo de argônio intermediário é opcional e tem a função de levantar o plasma ligeiramente e diluir o fluxo de gás interno na presença de solventes orgânicos [15].

A temperatura do plasma gerado é alta o suficiente para que seja necessário um isolamento térmico do tubo de quartzo externo. Este isolamento é obtido através de um fluxo de argônio tangencial ás paredes do tubo [101].

Na FIG. 11 é possível verificar o gradiente de temperatura no ICP, o que também dá nome às diferentes regiões do plasma. A Região de Indução, na base do plasma, é a região onde a transferência de energia de indução ocorre, desta forma é a região com mais alta temperatura no plasma, desta região até a cauda da pluma, no topo do plasma a temperatura sofre decaimento [15].

Quando a amostra é nebulizada e o aerossol é direcionado para o plasma ocorrem as seguintes etapas:

1. Dessolvatação: é a remoção do solvente das gotículas, resultando em partículas sólidas microscópicas ou um aerossol seco;

2. Vaporização: Decomposição das partículas em gás;

Estas etapas ocorrem predominantemente na região de preaquecimento.

3. Excitação: Estas etapas são antecessoras do processo de emissão de radiação das espécies excitadas.

Estes processos ocorrem na região inicial de radiação, e na região normal analítica, de onde a emissão analítica é normalmente coletada [15]. 
São vantagens da utilização do plasma como fonte de excitação as altas temperaturas alcançadas, comparando-se com técnicas que utilizam chama como fonte de ionização ou excitação, além do tempo de residência do analito no plasma que é cerca de duas vezes maior, o que proporciona uma excitação muito mais eficiente, aumentando o sinal e consequentemente a sensibilidade do método. Pode-se desprezar a formação de óxidos e hidróxidos do analito e a radiação de fundo é quase inexistente. A estabilidade e uniformidade do plasma permite a construção de curvas de calibração lineares em diversas ordens de grandeza de diversos elementos [101].

\subsubsection{Configuração da Tocha}

A emissão atômica oriunda da região analítica normal do plasma é utilizada para medidas espectrométricas. O ICP pode ter duas configurações diferentes para que a emissão seja observada, a configuração radial e a axial e alguns equipamentos possuem ambas as configurações. As duas configurações possuem vantagens e desvantagens de acordo com a sua aplicação [15].

$\mathrm{Na}$ configuração radial a tocha encontra-se na posição vertical, tem diversas aplicações, porém pode sofrer interferências no "background" (sinal de fundo) [15]. Já na configuração axial o plasma encontra-se na posição horizontal. Esta configuração permite a obtenção de melhores limites de deteç̧ão. No entanto algumas interferências espectrais e efeitos induzidos da matriz podem ocorrer. Estas interferências podem ser corrigidas com ações como: aumentando a resolução espectral, utilizando uma linha espectral alternativa ou utilizando uma correção interelementar [15].

\subsubsection{Monocromador/ Policromador}

Como uma das principais características desta técnica é a possibilidade de análise multielementar, é possível encontrar dois tipos de instrumentos disponíveis para esse propósito. O espectrômetro sequencial, que usa um monocromador e por assim dizer varre diferentes linhas de emissão em sequência. Os comprimentos de onda são determinados pelo usuário e o monocromador 
move-se rapidamente de um comprimento de onda para o próximo. A outra opção são os espectrômetros simultâneos que empregam policromadores ou espectrógrafos. Diversos espectrômetros modernos utilizam os espectrógrafos e um ou mais arranjos de detectores para monitorar múltiplos comprimentos de onda simultaneamente. Normalmente os instrumentos simultâneos são mais caros que os sistemas sequenciais.

\subsubsection{Transdutores}

Em termos gerais os transdutores são dispositivos de retransmissão de sinal, no entanto estes dispositivos são muito utilizados para a conversão de sinais. No caso de equipamentos de ICP-OES eles convertem os sinais elétricos recebidos pelo monocromador/ policromador em sinal de intensidade, no caso proporcional à concentração de analito na amostra. O dispositivo de acoplamento de carga (DAC) tem-se tornado um transdutor muito popular em arranjos de detectores em espectrômetros simultâneos e em alguns sequenciais. Esses dispositivos estão disponíveis contendo mais de 1 milhão de pixels para permitir uma cobertura ampla de comprimentos de onda [16] [101].

\subsection{Performance Analítica}

As regiões ultravioleta e visível do espectro eletromagnético são normalmente utilizadas na espectrometria atômica. Com a técnica de ICP-OES o número de elementos que podem ser determinados é relativo à janela de comprimento de onda cobertas pelos dois sistemas, colimados e dispersivos, para a determinação de alguns metais alcalinos pode ser realizada a leitura acima de $500 \mathrm{~nm}$ e para a determinação de outras espécies a leitura também pode ser realizada até mesmo abaixo de 160nm. O que deve ser observado na escolha das linhas espectrais, para que não ocorra problemas como a sobreposição de linhas. Para a seleção da melhor linha espectral é necessária a verificação dos seguintes parâmetros:

1. O comprimento de onda deve ser acessível para o sistema dispersivo e para o detector; 
2. O comprimento de onda deve mostrar nível de sinal apropriado (sensibilidade) para a concentração do elemento escolhido;

3. A linha espectral não deve apresentar interferências espectrais, ou estas devem ser passíveis de correção;

4. Utilizar uma linha espectral padrão como base para comparação das respostas obtidas. 


\section{VALIDAÇÃO DA METODOLOGIA ANALÍTICA}

De acordo com o Documento Orientativo do INMETRO DOQ-CGCRE008 [18] a validação de uma metodologia de análise é a forma de confirmar que o método é apropriado para o uso pretendido, conforme apresentado no Vocabulário Internacional de Metrologia - VIM [19]. Esta confirmação trata-se de uma verificação, mas nem toda verificação pode ser denominada como validação. Desta forma todos os métodos não normatizados, criados e/ou desenvolvidos fora do escopo da norma ou ampliações de um método normatizado precisam passar por uma série de testes que comprovem que o método é adequado para sua finalidade.

A validação de um método analítico também é importante para garantir a comparabilidade, rastreabilidade e confiabilidade dos resultados, pois quando um método é validado são utilizadas as mesmas referências definidas internacionalmente, como padrões e materiais de referência, para garantir a qualidade dos resultados gerados, pois estes resultados são, muitas vezes, importantes para a tomada de decisões, comparação com valores legislados, entre outras comparações.

O processo de estudo de um método analítico também envolve a estimativa de incertezas, que está atrelada aos resultados gerados espelhando a confiabilidade do método.

Muito embora não haja uma norma nacional e/ou internacional estabelecida para a validação de metodologias em geral, existem diversas diretrizes e recomendações, de órgãos como União Internacional de Química Pura e Aplicada (IUPAC), Organização Internacional para Padronização (ISO), Agência Nacional de Vigilância Sanitária (ANVISA), INMETRO entre outros. Em muitos casos laboratórios se submetem a acreditação juntamente aos órgãos competentes, como ANVISA e INMETRO no Brasil, para atender às exigências do mercado. Neste trabalho será utilizado como base para a realização da validação da metodologia analítica o Documento Orientativo do INMETRO DOQ CGCRE 008 que define parâmetros específicos a serem estudados para a validação de 
metodologias, dependendo da natureza do ensaio como apresentado na TAB. 4 [18].

TABELA 4: Parâmetros de validação conforme a natureza do ensaio

\begin{tabular}{|c|c|c|c|c|}
\hline \multirow[b]{2}{*}{ Testes } & \multicolumn{4}{|c|}{ Natureza do Ensaio } \\
\hline & Qualitativo & $\begin{array}{l}\text { Determinações } \\
\text { em maior teor }\end{array}$ & $\begin{array}{c}\text { Elementos } \\
\text { menores e } \\
\text { traços }\end{array}$ & $\begin{array}{c}\text { Propriedades } \\
\text { Físicas }\end{array}$ \\
\hline Precisão & & $\checkmark$ & $\checkmark$ & $\checkmark$ \\
\hline Seletividade & $\checkmark$ & $\checkmark$ & $\checkmark$ & $\checkmark$ \\
\hline $\begin{array}{c}\text { Tendência/ } \\
\text { Recuperação }\end{array}$ & & $\checkmark$ & $\checkmark$ & $\checkmark$ \\
\hline Robustez & $\checkmark$ & $\checkmark$ & $\checkmark$ & $\checkmark$ \\
\hline $\begin{array}{l}\text { Sensibilidade/ } \\
\text { Linearidade/ } \\
\text { faixa de } \\
\text { trabalho }\end{array}$ & & $\checkmark$ & $\checkmark$ & $\checkmark$ \\
\hline $\begin{array}{l}\text { Limite de } \\
\text { detecção }\end{array}$ & $\checkmark$ & & $\checkmark$ & \\
\hline $\begin{array}{c}\text { Limite de } \\
\text { quantificação }\end{array}$ & & & $\checkmark$ & \\
\hline
\end{tabular}

Fonte: [18]

Como os metais são elementos de baixa concentração no efluente estudado, estes podem ser chamados de elementos traço, pois estão em concentração abaixo de 1\%, e de acordo com o documento citado deverão ser realizadas as avaliações de precisão, seletividade, tendência/recuperação, robustez, sensibilidade/ linearidade/ faixa de trabalho, limite de detecção e limite de quantificação para que o método seja validado. Nos itens seguintes cada um destes parâmetros será definido. 


\subsection{Seletividade}

Segundo o VIM [19] a seletividade é uma propriedade do sistema de medição, que permite a obtenção de resultados para um ou vários mensurandos, de forma que estes valores sejam independentes de outras grandezas, fenômenos, corpo, substâncias e etc. De acordo com IUPAC [108] seletividade é definida como a medida que um método pode determinar analitos específicos numa mistura complexa sem interferências de outros componentes da mistura. Este parâmetro é aplicável às técnicas multielementares, se a seletividade não for garantida a linearidade, tendência e precisão estarão prejudicadas, logo este deve ser o primeiro parâmetro a ser avaliado na validação de uma metodologia [109].

Na prática a seletividade deve ser avaliada para que o sinal detectado pelo equipamento não seja oriundo de outros efeitos, senão do analito. Em análises químicas a matriz ou os analitos, podem causar a supressão ou aumento do sinal do analito, podendo causar resultados falso positivo ou falso negativo, desta forma a seletividade se mostra um parâmetro de extrema importância na validação da metodologia [18].

\subsection{Faixa de Trabalho e Linearidade}

Também chamado de intervalo de medição, segundo o VIM [19] é o conjunto de valores de grandezas da mesma natureza, que pode ser medido por um dado instrumento de medição ou sistema de medição, com incerteza de medição instrumental especificada, sob condições determinadas. Quando não se obtém resultados lineares em uma faixa extensa é possível determinar uma faixa de trabalho linear mais restrita, para que se atenda aos requisitos pretendidos, neste caso é necessário descrever claramente a faixa de trabalho no escopo da análise [109]. Linearidade é a capacidade de um método analítico de gerar resultados proporcionais à concentração de um analito. Pode ser definido por inspeção visual ou análises matemáticas.

Este parâmetro é muito importante para um método analítico, e pode ser determinada correlacionando-se a concentração do analito com o sinal medido. $\mathrm{Na}$ 
química esta correlação é utilizada para construir as curvas analíticas, e caso esta correlação seja linear, é possível determinar a concentração do analito em amostras desconhecidas, pois naquela faixa de trabalho o comportamento da curva analítica é conhecido. A curva analítica é uma relação gráfica da concentração do analito (no eixo das abcissas) com o sinal medido (no eixo das ordenadas) e a equação da reta é obtida conforme Equação 2 [18].

$$
y=a x+b
$$

Onde:

$y=$ resposta medida ou sinal analítico, variável dependente;

$x=$ concentração do analito, variável independente;

$a=$ coeficiente angular (expressa a inclinação da curva analítica);

$b=$ coeficiente linear (expressa a intersecção da curva aos eixos.

\subsection{Limite de Detecção (LD)}

É um valor medido onde a probabilidade de indicar falsamente a presença de um elemento é $\alpha$ e de indicar sua ausência é $\beta$ (Geralmente os valores de $\alpha$ e $\beta$ são 0,05, como indicado pela IUPAC) [19]. Também pode ser definido como a menor quantidade de analito que pode ser detectada, que gere algum sinal ou resposta do equipamento de análise [109, 110].

Existem diversas definições e diversos tipos de limites detecção utilizados na química analítica, neste trabalho serão estudados os limites de detecção do equipamento (LDE) e do método analítico (LDM). O que difere estes limites é que o limite de detecção do método é a menor concentração que pode ser detectada pelo equipamento em uma amostra que passou por todas as etapas do método analítico, como digestão ácida, armazenamento da amostra e análise por ICP-OES, enquanto que o limite de detecção do equipamento somente considera as condições de análise [110]. 


\subsubsection{Limite de Quantificação (LQ)}

O LQ é a menor quantidade de analito que pode ser determinada quantitativamente com a precisão e exatidão requerida pelo fim pretendido, ou seja, é a concentração de analito que produz um sinal suficientemente confiável para sua quantificação [109, 110].

\subsection{Exatidão}

A exatidão não é considerada uma grandeza, desta forma não the pode ser atribuído valor numérico. De acordo com o VIM a exatidão de medição é o grau de concordância entre um valor medido e o valor nominal ou valor verdadeiro atribuído a este. Assim um valor é considerado exato quando o erro de medição é o menor possível [19].

Como a exatidão de medição não pode ser expressa numericamente a recuperação e/ou tendência são formas usuais de se avaliar o grau de exatidão de uma medida [18].

\subsubsection{Recuperação ou Tendência}

A exatidão pode ser avaliada matematicamente por meio dos dados de recuperação, que trata da concordância entre a média de valores empíricos e um valor de referência. A tendência de um método é a diferença entre o valor de referência e a porcentagem de analito recuperada, esta tendência pode ser originada por erros sistemáticos inerentes ao método ou ao laboratório. Esta tendência deve ser corrigida ou demonstrada como desprezível [109].

Um método mais exato é aquele que apresenta maior recuperação e menor tendência possível, considerando as condições de análise, complexidade da matriz, e procedimento de preparo da amostra. Os critérios de aceitação de exatidão devem ser avaliados de acordo com a aplicação do método [109]. 


\subsection{Precisão}

É o grau de concordância que se obtém entre as diversas medidas realizadas em um mesmo objeto, ou objetos similares, quando medidos por um método de análises específico [19]. A precisão é normalmente avaliada por meio da repetitividade, precisão intermediária e reprodutibilidade, e é expressa em medidas de imprecisão (tais como: desvio padrão, e desvio padrão relativo). As condições de análise de precisão são [18]:

- Repetitividade: É quando se obtém a precisão de medição sob um conjunto de condições de repetitividade, ou seja, o mesmo procedimento de medição, mesmo operador, mesmo sistema de medição, mesmas condições de operação e mesmo local, bem como utilizando o mesmo objeto (amostra) ou similar em curto espaço de tempo [19];

- Precisão Intermediária: É quando se obtém a precisão de medição sob um conjunto de condições de precisão intermediária, ou seja, as quais incluem o mesmo procedimento de medição, mesmo operador, mesmo sistema de medição, mesmas condições de operação e mesmo local, o mesmo objeto (amostra) ou similar ao longo de um extenso período de tempo, outras condições também podem ser modificadas [19]. Em alguns casos opta-se por variar ao menos uma condição de análise (tempo, analista ou instrumento) [18];

- Reprodutibilidade: É quando se obtém a precisão de medição sob um conjunto de condições de reprodutibilidade, ou seja, diferentes locais, diferentes operadores, diferentes sistemas de medição em um mesmo objeto (amostra) ou similar e utilizando o mesmo método de análise [19];

Os critérios de aceitação de precisão devem ser avaliados de acordo com o uso do método [109]. 


\subsection{Robustez}

A robustez reflete as condições de confiabilidade do método. Pode ser definida como a capacidade de manter o método de análise inalterado (estável) por variações nas suas condições [18]. Este estudo pode ser utilizado para otimizar o método analítico, quando este está sendo desenvolvido, ou então pode ser utilizado para verificar a influência de fatores que podem variar caso o método seja implantado em outros laboratórios [111].

Não é obrigatória a realização deste estudo, mas ele é importante para a avaliação das influências que o método sofre no decorrer do seu uso, e quais variáveis devem ser cuidadosamente controladas durante a realização da análise, para que a precisão, exatidão e estabilidade do método sejam alcançadas.

\subsection{Estimativa de Incerteza}

É possível encontrar na literatura diversas definições para a incerteza de medição, mas de acordo com o VIM [19] a incerteza de medição é um parâmetro não negativo associado ao resultado de medição, que caracteriza a dispersão dos valores que podem ser atribuídos ao mensurável, com base nas informações/etapas do método de análise.

A incerteza de medição geralmente está associada a dois tipos de incertezas, as do tipo A, que podem ser avaliadas analisando a dispersão de um determinado número de repetições, avaliando distribuições estatísticas de valores oriundos de séries de medições (determinação de incerteza padrão da repetitividade do método analítico ou da repetitividade de medidas de volume, por exemplo). E as do tipo B, que são aquelas que não podem ser analisadas avaliando somente as repetições do mensurando como nas incertezas do tipo $A$, as incertezas do tipo B devem ser avaliadas levando em consideração informações de certificados de materiais de referência, valores publicados, certificados de calibração ou limites deduzidos pelo analista, utilizando-se de sua experiência [19]. 
De acordo com o Guia Internacional de Estimativa de Incertezas - GUM [112], existem diversas maneiras de realizar a estimativa de incerteza, e a aplicação do método analítico, sua natureza e a experiência do analista devem ser levados em consideração para obtê-la. É importante ressaltar que o objetivo desta estimativa não é obter a menor incerteza, mas sim a incerteza que represente a dispersão dos resultados obtidos pelo método estudado [112]. 


\section{MATERIAIS E MÉTODOS}

Para a obtenção dos resultados de metais em efluentes líquidos, as amostras são registradas, compostas, preservadas e preparadas para o processo de análise como apresentado resumidamente na FIG. 14.

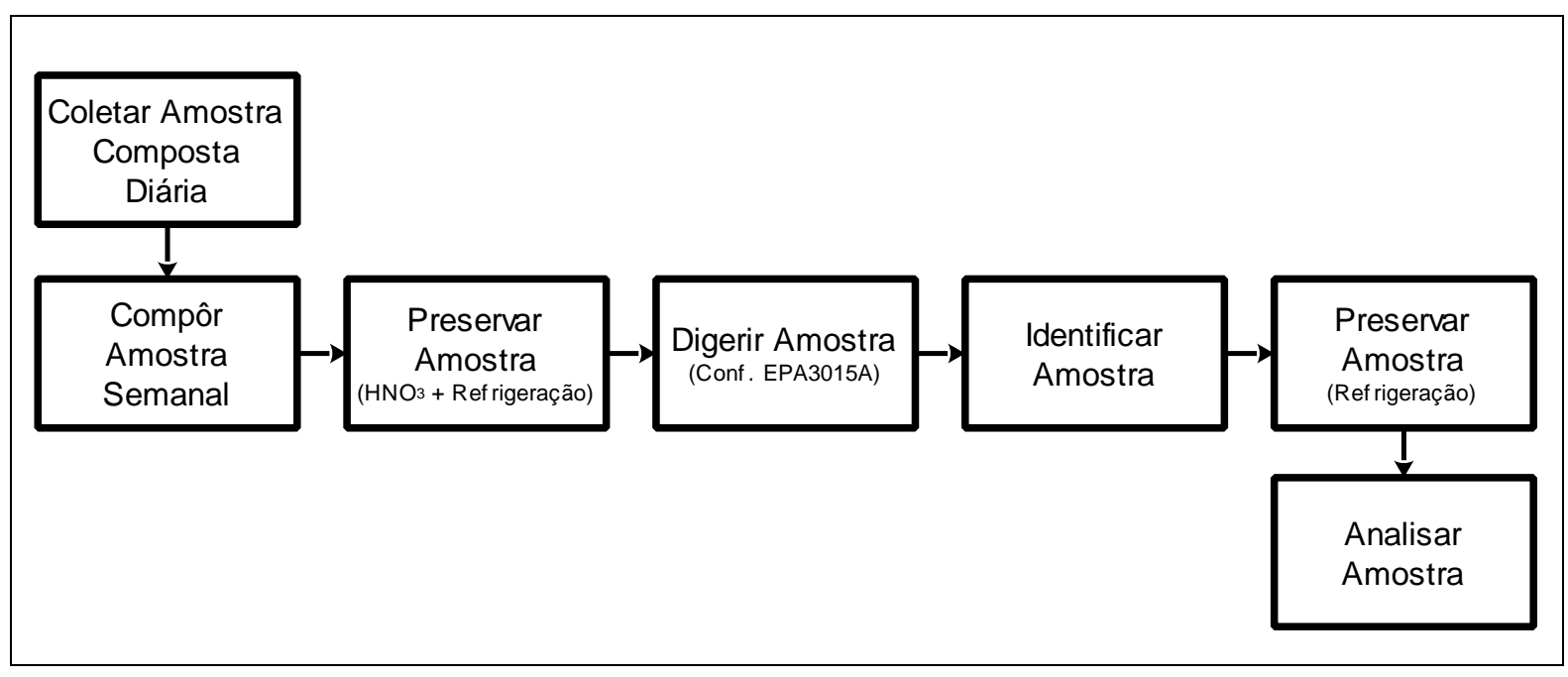

FIGURA 14: Esquema de coleta, preservação e pré-tratamento da amostra de efluente para análise

Neste capítulo são descritas tanto as etapas utilizadas para a coleta, preparo e análise das amostras quanto para a validação da metodologia em questão e também para a estimativa da Incerteza do método.

\subsection{Amostragem e Preservação das Amostras}

No IPEN a coleta de efluente é realizada na Estação de Monitoramento de Efluente (EME), localizada próxima à portaria norte do instituto.

As amostras são compostas diariamente, 1 L.h ${ }^{-1}$ durante 9 horas por dia, com o auxílio de uma bomba peristáltica (modelo Small Sampler 10 - Poli Control - FIG. 15 A), e mantidas sob refrigeração para sua conservação (FIG. 15 B). 


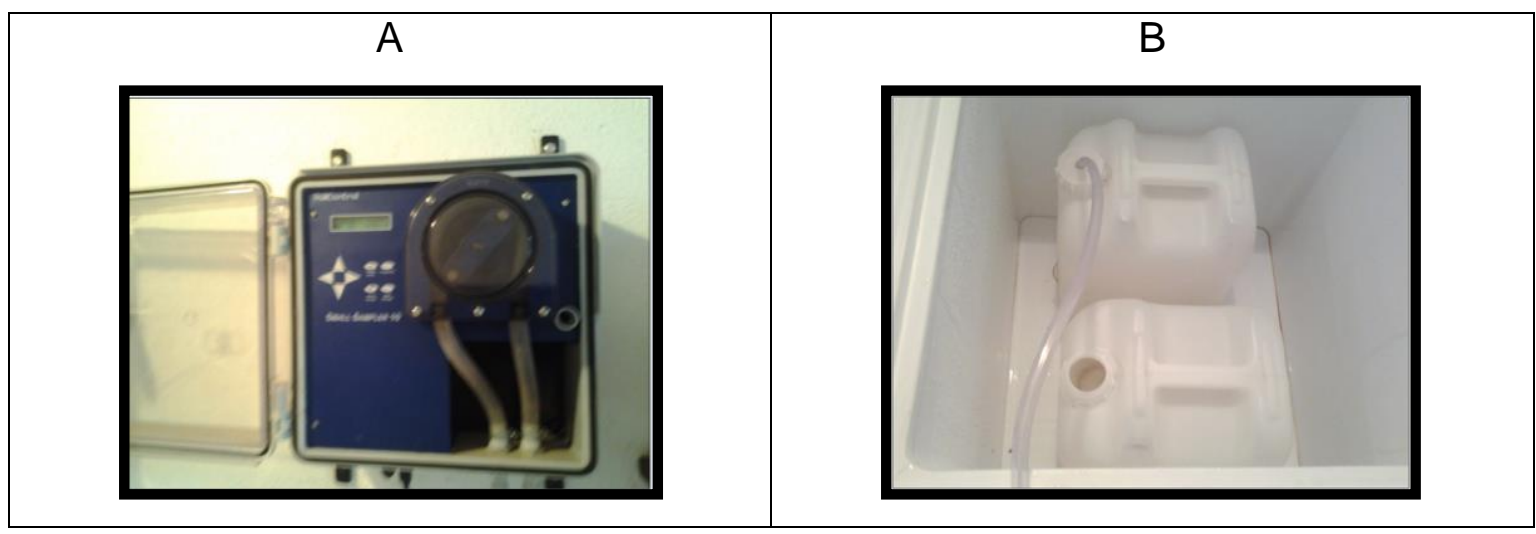

FIGURA 15: (A) Bomba peristáltica utilizada na Coleta do Efluente (B) Recipientes utilizados no processo de coleta do efluente

A partir da amostra composta diariamente, é retirada uma alíquota de $50 \mathrm{~mL}$ que compõe a amostra semanal, que é posteriormente acidificada, adicionando-se $1 \mathrm{~mL}$ de ácido nítrico $\left(\mathrm{HNO}_{3} \mathrm{P}\right.$. A. 65\%). As amostras de efluente são armazenadas e coletadas conforme procedimentos descritos na norma ANA CETESB [113] e Standard Methods for the Examination of Water and Wastewater [114], para ensaios de metais e outras características. São considerados os tipos de frasco, volume necessário, preservação e prazo para a realização das análises.

\subsection{Preparo das Amostras: Digestão Ácida}

Para que os analitos sejam disponibilizados adequadamente para a análise, é necessário realizar a digestão ácida das amostras, de modo que os metais analisados sejam identificados em sua fração total. O procedimento de digestão utilizado é o método da Agência de Proteção Ambiental - EPA 3015A [115]. Este método baseia-se na digestão ácida da amostra em sistema de microondas com pressão e temperatura controlados. O procedimento encontra-se resumidamente apresentado na FIG. 16. 


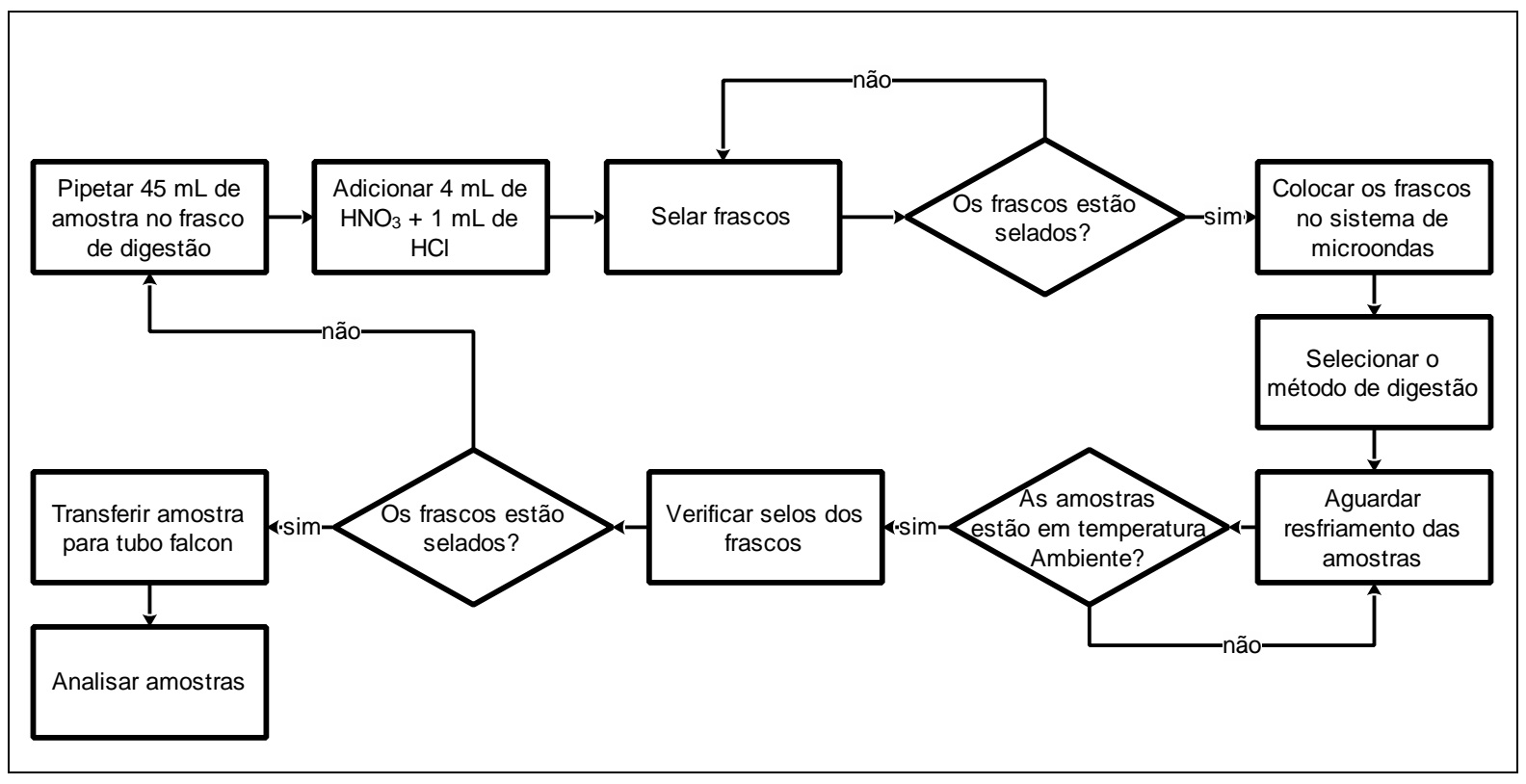

FIGURA 16: Esquema simplificado do Processo de Digestão das Amostras

Fonte: adaptado de ENVIRONMENTAL PROTECTION AGENCY, 2007 [115]

O método de digestão descrito acima sugere a utilização do perfil de temperatura e pressão apresentados na FIG. 17, onde as amostras devem atingir temperatura de $170 \pm 5^{\circ} \mathrm{C}$ em 10 minutos, aproximadamente, e permanecer nesta temperatura também por 10 minutos [115]. O programa utilizado para a digestão das amostras está descrito na TAB. 5.

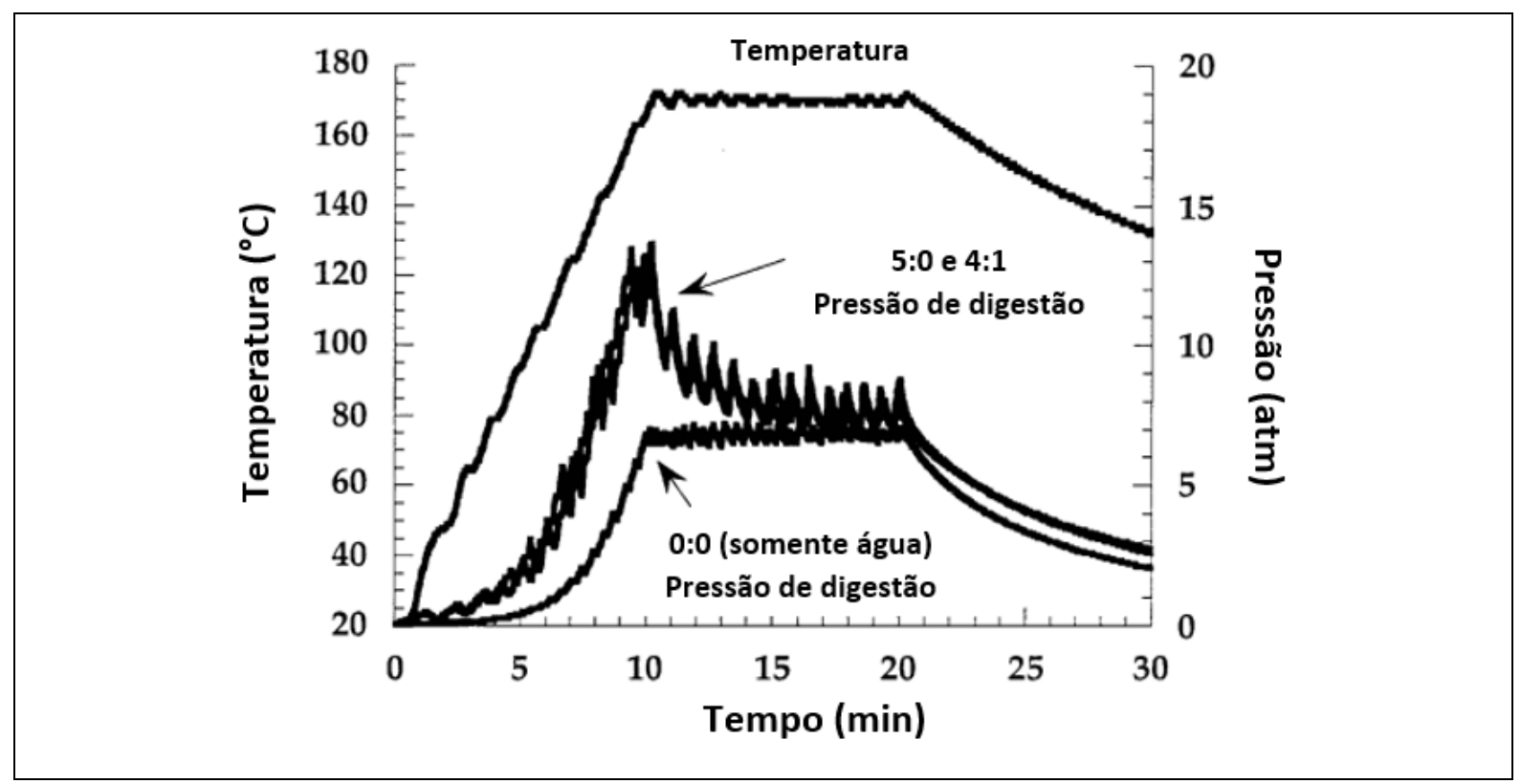

FIGURA 17: Perfil de pressão e temperatura para a digestão das amostras

Fonte: adaptado de ENVIRONMENTAL PROTECTION AGENCY, 2007 [115] 
TABELA 5: Programa utilizado no sistema de microondas

\begin{tabular}{cc}
\hline Parâmetros & Condições \\
\hline Potência $(\%)$ & 100 \\
Pressão (atm) & 85 \\
Tempo de Pressurização $(\mathrm{min})$ & $10: 00$ \\
Temperatura $\left({ }^{\circ} \mathrm{C}\right)$ & 165 \\
Tempo de Digestão & $20: 00$ \\
\hline
\end{tabular}

Para a realização desta etapa são utilizados ácido nítrico (P. A. 65\%) e ácido clorídrico (P. A. 37\%) e sistema de microondas com controle de pressão e temperatura (Modelo MDS 2000 - CEM).

A cada lote de amostras também são preparados no processo de digestão um branco (onde a amostra é substituída por água ultrapura), uma duplicata de uma das amostras do lote e uma adição padrão em uma das amostras do lote (geralmente é utilizada a mesma amostra para o preparo da duplicata e da adição), para que possa ser realizado o controle de qualidade periódico do processo de preparo das amostras, o que permite a detecção de contaminações ou variações indesejadas nesta etapa.

\subsection{Análise por ICP-OES}

O equipamento utilizado para a realização das análises de metais em efluente foi o Spectro Flame M120, Spectro Analytical Instruments, equipado com tocha axial, nebulizador concêntrico Meinhard e câmara de spray tipo Scott. Os parâmetros do equipamento seguem listados abaixo.

- Potência do Plasma: 1200 W;

- Velocidade da Bomba: 30 rpm;

- Vazão do gás refrigerante: $12 \mathrm{~L} / \mathrm{min}$;

- Vazão auxiliar: $1 \mathrm{~L} / \mathrm{min}$;

- Pressão do nebulizador: 3,4 bar;

- Coeficiente de correlação mínimo: 0,9;

- Tempo total para leitura: $28 \mathrm{~s}$. 


\subsection{Validação de Metodologia}

De acordo com o Documento do INMETRO (DOQ-CGCRE-008) a validação de uma metodologia de análise é a forma de confirmar que o método é apropriado para o uso pretendido [18]. Os testes definidos pelo mesmo documento do INMETRO diferem dependendo da natureza do ensaio, para testes que têm como objetivo a análise quantitativa de elementos menores e traços é necessário realizar o estudo dos parâmetros seletividade, linearidade, limite de detecção, limite de quantificação, precisão, exatidão e robustez.

Para a avaliação de cada um dos parâmetros foi realizado um planejamento dos ensaios de validação e todas as análises foram realizadas utilizando padrões certificados, lidos em uma quantidade de replicatas estatisticamente significativa ou representando a rotina do laboratório, o espaço de tempo e modo de preparo dos padrões foram previamente estipulados para avaliar o comportamento do método.

Para a avaliação dos resultados experimentais foram utilizadas diversas ferramentas estatísticas, bem como a experiência do analista para verificar se os estudos refletiam a rotina laboratorial, utilizando o método em questão. Os testes estatísticos utilizados seguem descritos nos itens abaixo e foram baseados na Planilha de Validação de Métodos Analíticos desenvolvida por Hélio Furusawa [116], nas planilhas exemplo do Livro Quality Assurance and Quality Control in the Analytical Chemical Laboratory [117] e no Guia para Expressão de Incerteza de Medição [112]. Os testes estatísticos utilizados estão descritos nos itens abaixo.

\subsubsection{Faixa de Trabalho}

Para a avaliação da faixa de trabalho a linearidade é um parâmetro imprescindível para a determinação da concentração no analito em amostras desconhecidas, e este parâmetro vai determinar o nível de correlação existente entre a concentração do analito e o sinal gerado pelo equipamento. A faixa de trabalho e faixa linear podem não coincidir de acordo com o método, os efeitos da matriz ou a técnica utilizada [14]. 
De acordo com a literatura e a prática laboratorial é possível verificar que a técnica ICP-OES possui grande faixa linear, possibilitando ao analista que opte pela faixa de trabalho com base no histórico de amostras ou outros fatores importantes $[14,15]$. Desta forma foi decidido por utilizar os dados do histórico de resultados de metais dos anos de 2013 e 2014 (obtidos no PMA-Q), os valores estabelecidos para legislação ambiental vigente e também a experiência do analista para a decisão da melhor faixa de trabalho a ser utilizada para cada elemento, possibilitando maior confiabilidade na obtenção dos resultados.

\subsubsection{Seletividade}

A avaliação da seletividade pode ser realizada de diversas maneiras, deve ser levada em consideração para esta avaliação a experiência do analista, e verificar se os testes aplicados estão refletindo as condições do método de análise.

Neste trabalho, para a avaliação deste parâmetro, foram obtidos os espectros nas linhas de emissão selecionadas para cada um dos analitos com o padrão mais concentrado da curva analítica. A seguir foi avaliada a interferência dos elementos $\mathrm{Al}, \mathrm{Fe}, \mathrm{Ca}$ e $\mathrm{Na}$ nas linhas selecionadas para cada analito, avaliando o espectro. Foram utilizadas soluções com as seguintes concentrações: Al (50mg. $\left.\mathrm{L}^{-1}\right)$, Fe (50mg. $\mathrm{L}^{-1}$ e $\left.10 \mathrm{mg} \cdot \mathrm{L}^{-1}\right)$, Ca $\left(50 \mathrm{mg} \cdot \mathrm{L}^{-1}\right)$ e $\mathrm{Na}\left(50 \mathrm{mg} \cdot \mathrm{L}^{-1}\right)$. Estes elementos foram avaliados por serem componentes majoritários do efluente em estudo e por possuírem um amplo espectro de emissão, o que poderia causar sobreposição dos espectros, portanto, resultados falso-positivos.

Para a avaliação dos espectros foi considerado satisfatório quando os espectros dos possíveis interferentes apresentaram comportamento similar à linha de base, também foi observado deslocamento de pico ou elevação do "background" (ruído).

Após a avaliação dos espectros foram construídas as curvas analíticas com e sem matriz. Os padrões da curva analítica com matriz foram analisados e posteriormente a média do branco da amostra foi subtraído de cada um deles, pois a amostra continha baixa concentração dos analitos. Valendo-se destes dados foi 
realizada avaliação visual das curvas, e foi considerado como satisfatória a sobreposição das curvas analíticas com e sem matriz.

Também foi realizado o teste $\mathrm{F}$ de Snedecor (Teste de Homogeneidade das Variâncias), calculado conforme Equação 3, para comparação da variação entre as sensibilidades das curvas analíticas com e sem matriz, calculada conforme Equação 4 [116]. Este estudo é de extrema importância, pois é por meio do estudo da equivalência das sensibilidades das curvas analíticas que será possível avaliar se há grandes diferenças entre as quantificações realizadas com as curvas analíticas com e sem matriz.

$$
\mathrm{F}_{\text {calculado }}=\frac{\mathrm{S}_{1}^{2}}{\mathrm{~S}_{2}^{2}}
$$

Onde:

$S_{1}^{2}=$ Variância das intensidades (para 10 replicatas da curva com matriz, neste estudo);

$\mathrm{S}_{2}^{2}=$ Variância das intensidades (para 10 replicatas da curva sem matriz, neste estudo);

$$
\text { Sensibilidades }=\frac{\left(\mathrm{I}_{\mathrm{P} 1}-\mathrm{I}_{\mathrm{P} 5}\right)}{\left(\mathrm{C}_{\mathrm{P} 1}-\mathrm{C}_{\mathrm{P} 5}\right)}
$$

Onde:

$\mathrm{I}_{\mathrm{P} 1}=$ Intensidade do ponto $1 ;$

$\mathrm{I}_{\mathrm{P} 5}=$ Intensidade do ponto 5;

$\mathrm{C}_{\mathrm{P} 1}=$ Concentração do ponto 1 ;

$\mathrm{C}_{\mathrm{P} 5}=$ Concentração do ponto 5;

Os resultados de $F_{\text {calculado }}$ foram comparados com o valor de $F_{\text {crítico }}$ (considerando devido número de graus de liberdade e intervalo de confiança de 95\%). Foram considerados satisfatórios resultados de $F_{\text {calculado }}<F_{\text {crítico, o que }}$ 
demonstra que as sensibilidades entre as curvas com e sem matriz não possuem diferenças significativas.

\subsubsection{Linearidade}

Para a demonstração da linearidade é necessário que sejam utilizadas ferramentas estatísticas que demonstrem a correlação entre as concentrações e a intensidade de sinal medido. Os dados utilizados para a avaliação deste parâmetro serão determinados a partir dos resultados obtidos no teste de seletividade.

Para a avaliação da linearidade foram utilizados os dados dos cinco pontos de concentração de cada uma das curvas analíticas construídas. Inicialmente foi realizado o teste t para avaliar o desvio da linearidade das curvas, ou seja, se os pontos pertencem à mesma reta. Os cálculos foram realizados com base nas Equações 5 (cálculo de resíduos) e Equação 6 (teste t) para o cálculo dos resíduos e do t calculado [116].

$$
r=\frac{\sum(x-\bar{x})(y-\bar{y})}{\sqrt{\sum(x-\bar{x})^{2} \sum(y-\bar{y})^{2}}}
$$

Onde:

$\mathrm{x}$ e $\mathrm{y}=$ respostas dos analitos nas soluções;

$\overline{\mathrm{x}} \mathrm{e} \overline{\mathrm{y}}=$ médias das respostas dos analitos nas soluções.

$$
\mathrm{t}_{\text {calculado }}=\frac{\text { resíduo }}{\mathrm{S}_{\mathrm{r}} / \sqrt{\mathrm{n}}}
$$

Onde:

resíduo $=\left|\mathrm{x}_{\text {medido }}-\mathrm{x}_{\text {calculado }}\right|$

$\mathrm{S}_{\mathrm{r}}=$ desvio padrão dos resíduos

$\mathrm{n}=$ número de pontos

Os resultados de $\mathrm{t}$ tabelado foram comparados com $\mathrm{o}$ valor de $\mathrm{t}$ crítico (considerando devido número de graus de liberdade e intervalo de confiança de $95 \%$ ). Foram considerados satisfatórios resultados de $t$ calculado $<t$ crítico, o que 
demonstra que a curva analítica até aquele ponto possui comportamento linear, com base na dispersão dos resíduos de cada ponto.

Posteriormente foi realizada a avaliação do coeficiente de correlação linear ( $r$ ), este coeficiente determina qual a correlação entre os pontos da curva analítica, e foi obtido pelo software Smart Analyzer da Spectro, e de acordo com o INMETRO (2003) $r \geq 0,9$ pode ser considerado satisfatório [18]. A avaliação visual das curvas analíticas também foi utilizada para a análise do ajuste dos pontos de cada curva analítica, foi considerado satisfatório ajuste linear dos pontos, bem como a análise dos gráficos dos resíduos absolutos, que foi considerado como satisfatória baixa dispersão entre os pontos de cada concentração, e avaliação dos resíduos normalizados, onde foi considerado satisfatório dispersão dos pontos entre -2 e +2 e comportamento linear dos pontos.

A Análise de Variância (ANOVA) foi utilizada para verificar falta de significância das regressões (considerado satisfatório $F$ calculado $\geq F$ crítico), falta de ajuste (considerado satisfatório $F$ calculado $\leq F$ crítco) e falta de correlação entre as intensidades medidas e suas respectivas concentrações (\% de variação explicada e \% de variação explicável devem estar o mais próximo de 100\%).

Em complemento ao estudo da linearidade foram avaliados os gráficos de intervalo de confiança das curvas analíticas para avaliar a confiança dos resultados ao longo da curva analítica. É considerado satisfatório quando o intervalo de confiança não apresenta grandes variações mesmo nos pontos mais baixos ou mais altos da curva analítica, pois quanto maior o intervalo de confiança maior a dispersão dos dados [118]. O intervalo de confiança demonstra a confiabilidade das quantificações realizadas com o método proposto.

\subsubsection{Limite de Detecção do Equipamento}

O Limite de detecção do equipamento foi obtido pelo Software Smart Analyzer da Spectro, que leva em consideração 3 (três) vezes a razão sinal-ruído de cada curva analítica construída. 


\subsubsection{Limite de Detecção do Método (LDM)}

Para a determinação deste parâmetro podem ser utilizadas as leituras do branco, brancos da amostra ou adição de baixas concentrações de analito no branco da amostra, como orientado no DOQ CGCRE 008 do INMETRO [18]. Neste trabalho foram realizadas adições de concentração igual ao menor ponto da curva analítica em amostras com baixa concentração dos analitos, uma vez que não foi possível obter o branco da amostra. A partir dos resultados das análises o LDM foi determinado a partir da Equação 7 .

$$
L D M=0+t . s
$$

Onde:

$s=$ Desvio padrão dos resultados de 7 replicatas;

$t=\mathrm{t}$ de Student (nível de confiança de $99 \%$ e 6 graus de liberdade $=$ 3,70743).

\subsubsection{Limite de Quantificação do Método}

O Limite de Quantificação do Método (LQM) pode ser determinado de diversas maneiras, desde que seja demonstrado que a precisão desejada pôde ser alcançada no limite determinado. Neste trabalho o Limite de Quantificação foi determinado como o primeiro ponto da curva analítica, também foi observado se 0 desvio padrão relativo (DPR), calculado conforme Equação 8, estava de acordo com o aceitável para a precisão do método.

$$
\operatorname{DPR} \%=\left(\frac{\mathrm{S}}{\overline{\mathrm{X}}}\right) \cdot 100
$$

Onde:

DPR\% = Desvio Padrão Relativo, em \%;

$\mathrm{s}=$ Desvio padrão;

$\overline{\mathrm{x}}=$ Média. 
Para esta determinação foram realizadas adições de concentração igual ao menor ponto da curva analítica em amostras com baixa concentração dos analitos para a verificação de parâmetros como a exatidão e precisão.

\subsubsection{Precisão}

A precisão foi avaliada em termos de repetitividade, precisão intermediária e reprodutibilidade, conforme descrito nos itens abaixo.

\subsubsection{Repetitividade}

Neste trabalho foram avaliadas as triplicatas da leitura das adições realizadas para as digestões das amostras coletadas em 2013 e 2014. Os resultados foram expressos em DPR [18]. Foram considerados satisfatórios DPR $\leq 16 \%$, por conta da baixa concentração dos analitos.

\subsubsection{Precisão Intermediária}

Para a avaliação deste parâmetro foram utilizadas as leituras de duplicatas preparadas independentemente, ou seja, uma amostra foi pipetada, preparada e digerida em duplicidade em frascos independentes e as duas amostras foram analisadas no mesmo equipamento durante o mesmo lote de análises. Os resultados foram comparados conforme Equação 9 [18].

$$
\% \mathrm{C}=\frac{\mathrm{R}_{\text {Amostra }}}{\mathrm{R}_{\text {duplicata }}} \cdot 100
$$

Onde:

$\% \mathrm{C}=$ Compatibilidade das duplicatas, em \%;

$\mathrm{R}_{\mathrm{Amostra}}=$ Resultado da análise, em mg. $\mathrm{L}^{-1}$;

$\mathrm{R}_{\text {duplicata }}=$ Resultado da análise da duplicata em mg. $\mathrm{L}^{-1}$.

Foi considerado como satisfatória compatibilidade dos resultados de $80 \%$ a $120 \%[119]$. 


\subsubsection{Reprodutibilidade}

Avalia a precisão sob condições variadas, ou seja, diferentes métodos, em tempos diferentes entre outras variações [18]. Para a análise da reprodutibilidade serão utilizados os resultados do Programa Interlaboratorial da Rede Metrológica do Rio Grande do Sul, os laboratórios do CQMA participam deste programa desde 2009. Os resultados foram avaliados segundo o cálculo da média de consenso (mediana) e z-score, apresentado na Equação 10 [120].

$$
\mathrm{Z}=\frac{\left(\mathrm{x}_{\mathrm{i}}-\overline{\mathrm{x}}\right)}{\sigma}
$$

Onde:

$\mathrm{x}_{\mathrm{i}}=$ Resultado do laboratório;

$\overline{\mathrm{X}}=$ média da população;

$\sigma=$ desvio padrão populacional.

Com base na média de consenso os resultados são classificados da seguinte maneira:

$-2 \leq|Z| \leq 2=$ Resultados Satisfatório;

$-3<|Z|<-2$ ou $2<|Z|<3=$ Resultados Questionáveis;

$-3 \geq|Z| \geq 3=$ Resultados Insatisfatórios.

Foi elaborado um gráfico para a avaliação da precisão e exatidão dos resultados obtidos.

\subsubsection{Recuperação}

Neste trabalho a exatidão será avaliada por meio dos resultados de Recuperação. Para esta avaliação foram utilizados os resultados das adições realizadas para as digestões das amostras coletadas em 2013 e 2014. As concentrações nominais das adições estão apresentadas na TAB. 6. A recuperação foi calculada utilizando a Equação 11 [18]. 


$$
\mathrm{R} \%=\left(\frac{\mathrm{C}_{1}-\mathrm{C}_{2}}{\mathrm{C}_{3}}\right) \cdot 100
$$

Onde:

$R \%=$ Porcentagem Recuperada;

$C_{1}=$ Concentração da adição, em mg. $\mathrm{L}^{-1}$;

$C_{2}=$ Concentração sem adição, em mg. $\mathrm{L}^{-1}$;

$C_{3}=$ Concentração adicionada, em $\mathrm{mg} \cdot \mathrm{L}^{-1}$.

TABELA 6: Concentrações nominais adicionadas nas amostras coletadas em 2013 e 2014

\begin{tabular}{ccccccc}
\hline Elemento & $\mathbf{B}$ & $\mathbf{S n}$ & $\mathbf{C d}$ & $\mathbf{B a}$ & $\mathbf{C r}$ & $\mathbf{C u}$ \\
\hline $\begin{array}{c}\text { Concentração } \\
\text { mg.L-1 }\end{array}$ & 0,100 & 0,500 & 0,100 & 0,100 & 0,100 & 0,100 \\
\hline Elemento & $\mathbf{F e}$ & $\mathbf{M n}$ & $\mathbf{N i}$ & $\mathbf{P b}$ & $\mathbf{~} \mathbf{n}$ & \\
\hline $\begin{array}{c}\text { Concentração } \\
\text { mg.L-1 }\end{array}$ & 0,100 & 0,100 & 0,100 & 0,075 & 0,100 & \\
\hline
\end{tabular}

Foi considerado satisfatória recuperação de $80 \%$ a $120 \%$.

\subsubsection{Robustez}

Uma das opções para determinar a robustez de um método analítico é por meio do teste de Youden. Onde se utiliza uma combinação de fatores para avaliar a influência de cada fator. Este teste permite avaliar a robustez do método e também ordenar a influência de cada uma das variações estudadas. Para a realização deste teste são selecionadas 7 variáveis nominais do método (representadas por letras maiúsculas) e 1 variação para cada uma destas variáveis (representada pela respectiva letra minúscula), as variáveis escolhidas podem ser vistas na TAB. 7. São realizados 8 ensaios distintos (conforme TAB. 8) e com a 
média de resultados (obtida pela leitura em triplicata) são realizados os cálculos para avaliação da robustez.

TABELA 7: Variações selecionadas para a avaliação da robustez

\begin{tabular}{cccc}
\hline $\begin{array}{c}\text { Fator na } \\
\text { tabela }\end{array}$ & Fator de variação & Valor Nominal & $\begin{array}{c}\text { Variação } \\
\text { estudada }\end{array}$ \\
\hline A/ a & Quantidade de $\mathrm{HNO}_{3}$ & $4,0 \mathrm{~mL}$ & $3,0 \mathrm{~mL}$ \\
B/ b & Quantidade de $\mathrm{HCl}$ & $1,0 \mathrm{~mL}$ & $0,5 \mathrm{~mL}$ \\
C/ $\mathbf{c}$ & Potência do Plasma & 1200 & 1400 \\
D/ d & Temperatura do & $22{ }^{\circ} \mathrm{C}$ & $26{ }^{\circ} \mathrm{C}$ \\
E/ e & Laboratório & $3,4 \mathrm{bar}$ & $3,0 \mathrm{bar}$ \\
$\mathbf{F} / \mathbf{f}$ & Velocidade da bomba & $20 \mathrm{rpm}$ & $30 \mathrm{rpm}$ \\
G/ g & Qualidade da água & Água Milli Q & Água tipo II \\
\hline
\end{tabular}

TABELA 8: Combinação de ensaios para a avaliação da robustez de acordo com o Teste de Youden

\begin{tabular}{cccccccccc}
\hline & \multicolumn{8}{c}{ Combinação Ensaiada } \\
Fator & 1 & $\mathbf{2}$ & $\mathbf{3}$ & $\mathbf{4}$ & $\mathbf{5}$ & $\mathbf{6}$ & $\mathbf{7}$ & $\mathbf{8}$ \\
\hline A/ a & A & A & A & A & a & a & a & a \\
B/ b & B & B & b & b & B & B & b & b \\
C/ C & C & C & C & C & C & C & C & C \\
D/ d & D & D & d & d & d & d & D & D \\
E/ e & E & e & E & e & e & E & e & E \\
F/ f & F & f & f & F & F & f & $f$ & F \\
G/ g & G & g & g & G & g & G & G & g \\
Resultado & S & t & u & V & w & $\mathbf{x}$ & $\mathbf{y}$ & z \\
\hline
\end{tabular}

Fonte: Instituto Nacional de Metrologia, Qualidade e Tecnologia, 2003 [121]

Para a avaliação dos resultados foi subtraída a média dos resultados da variação estudada (resultados correspondentes às letras minúsculas) da média dos valores nominais (resultados correspondentes às letras maiúsculas) para cada um dos fatores, conforme Equação 12. 


$$
\text { Efeito A/a }=\left(\frac{s+t+u+v}{4}\right)-\left(\frac{w+x+y+z}{4}\right)
$$

Foram utilizadas duas formas de avaliação gráfica, primeiramente foi avaliada a probabilidade de distribuição normal dos resultados obtidos, para a verificação da presença de pontos discrepantes e também do tamanho da influência dos fatores. Nesta avaliação os pontos devem apresentar comportamento similar à uma reta e distribuição entre +2 e -2 para caracterizar distribuição normal e 95\% de confiança [111].

A posteriori foi elaborado o gráfico de Rankit, com as informações de Margem de Erro (ME do inglês), calculada conforme Equação 13, e Margem de Erro Simultânea (SME do inglês), calculados conforme Equação 14, de acordo com a literatura se o efeito estiver entre ME e SME pode ser considerado possivelmente significante, ou seja, um sinal de atenção para variações naquele efeito, e se o fator apresentar resultados acima de SME é considerado um fator significante para o resultado das análises, ou seja, o método não apresenta robustez para variações naquele fator [111].

$$
\mathrm{ME}=t_{(1-\alpha / 2, d f)} \cdot s_{1}
$$

Onde:

$M E=$ Margem de Erro;

$\mathrm{t}=$ valor da probabilidade $\mathrm{t}$ de Student;

$1-\alpha / 2=0,975$

$d f=\mathrm{m}=$ número de efeitos absolutos com valor menor que 2,5 $S_{0}$

$s_{0}=1,5 . \underset{i}{\text { mediana }}\left|E_{i}\right|$

$$
s_{1}=\sqrt{m^{-1} \sum E_{i}^{2}}
$$

$$
\operatorname{SME}=t_{\left(1-\alpha^{*} / 2, d f\right)} \cdot s_{1}
$$

Onde: 
$\alpha^{*}=1-(1-\alpha)^{(1 / m)}$ (nível de significância Sidak).

\subsection{Incerteza de Medição}

Para a estimativa da incerteza é necessária a realização de um estudo do método analítico avaliando cada etapa do tratamento da amostra e da análise para a obtenção do mensurando. As etapas realizadas neste trabalho podem ser observadas nos itens abaixo.

\subsubsection{Determinação do Modelo Matemático}

Para a estimativa das incertezas foi realizada a avaliação do modelo matemático utilizado para a obtenção do mensurando. A Equação 15 apresenta quais as variáveis influenciam na quantificação da concentração dos metais em efluente.

$$
C=\frac{C A x V_{\text {final }}}{V_{\text {inicial }}} \times \frac{1}{R}
$$

Onde:

$C=$ Concentração do elemento em efluente $\left(\mathrm{mg} \cdot \mathrm{L}^{-1}\right)$;

$C A=$ Concentração do elemento de acordo com a curva analítica $\left(\mathrm{mg} \cdot \mathrm{L}^{-1}\right)$;

$V_{\text {final }}=$ Volume final da Amostra após a digestão $(50 \mathrm{~mL})$;

$V_{\text {inicial }}=$ Volume inicial da amostra $(45 \mathrm{~mL})$

$R=$ Recuperação do método.

Foi considerada a variável $C A$, pois a curva analítica é, geralmente, uma grande fonte de incerteza de métodos analíticos, uma vez que toda e qualquer quantificação é realizada através de uma relação com a mesma. As variáveis $V_{\text {final }}$ e $V_{\text {inicial }}$ foram considerados, pois além da medida de volume de amostra, são adicionados ácidos à amostra para que seja possível realizar a liberação dos analitos no processo de digestão ácida das amostra, e a variável $R$ foi considerada mesmo para os elementos que apresentaram recuperação equivalente a 100\% para manter um padrão de modelo matemático para todos os elementos, mas este 
fator somente causará influência significativa para os elementos que apresentaram recuperação significativamente diferente de $100 \%$.

\subsubsection{Levantamento das Fontes de Incerteza}

Para este levantamento foi elaborado um diagrama de Ishikawa (também conhecido como espinha de peixe) onde foram consideradas todas as etapas do preparo e análise das amostras, conforme demonstrado na FIG. 18. Após o levantamento das fontes de incertezas, foi calculada a incerteza padrão de cada contribuinte, estas foram combinadas e expandidas para a obtenção da estimativa da incerteza de medição [112].

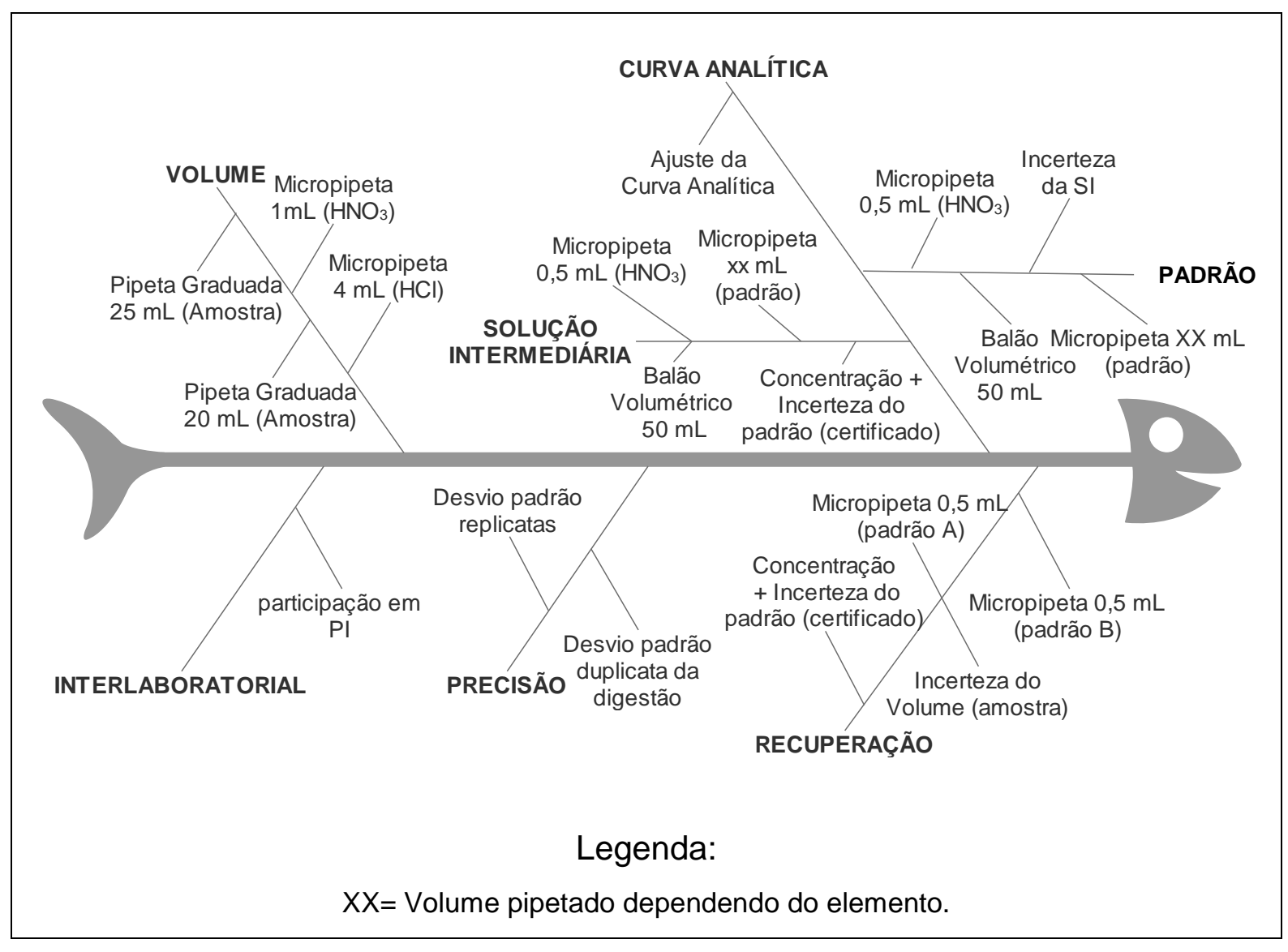

FIGURA 18: Diagrama de Ishikawa para levantamento das fontes de incerteza

Os fatores considerados como contribuinte seguem descritos nos itens abaixo. 


\subsubsection{Incerteza do Volume}

No processo de preparo das amostras foram considerados os fatores que contribuíram para variações de volume inicial e volume final da amostra a ser analisada. A etapa que contribui para a incerteza do volume da amostra é o processo de digestão ácida. Nesta etapa as amostras são medidas em duas alíquotas (25 mL e $20 \mathrm{~mL}$ ) utilizando uma pipeta graduada. Posteriormente é adicionada à amostra os ácidos utilizando micropipetas automáticas. Como fatores que provocam variações à estas medidas foram consideradas a variação da temperatura do laboratório $\left(5^{\circ} \mathrm{C}\right)$, calculada conforme Equação 16 , variações de volume atribuídos à vidraria ou pipetas automáticas, calculadas levando em consideração o erro máximo da pipeta (calculada conforme Equação 17) o certificado da pipeta (calculada conforme Equação 18) ou o DPR da pipeta (calculado conforme Equação 19) e a repetitividade da medida de cada uma das pipetas utilizadas (calculada conforme Equação 20).

$$
\mu\left(V_{\text {temp }}\right)=\frac{\Delta T \cdot Q \cdot V}{\sqrt{3}}
$$

Onde:

$\mu\left(V_{\text {temp }}\right)=$ Incerteza do volume em função da variação de temperatura $(\mathrm{mL})$;

$\Delta T=$ Variação de Temperatura $\left({ }^{\circ} \mathrm{C}\right)$;

$Q=$ Dilatação Térmica da água $\left(0,000124^{\circ} \mathrm{C}-1\right)$;

$V=$ Volume medido $(\mathrm{mL})$;

$\sqrt{3}=$ assumindo distribuição retangular.

$$
\mu\left(V_{\text {pipeta }}\right)=\frac{\text { Erro máximo }}{\sqrt{6}}
$$

$\mu\left(V_{\text {pipeta }}\right)=$ Incerteza do volume em função de variações da vidraria ou micropipeta $(\mathrm{mL})$;

Erro Máximo = Erro máximo permissível $(\mathrm{mL})$;

$\sqrt{6}=$ assumindo distribuição triangular. 


$$
\mu\left(V_{\text {pipeta }}\right)=\frac{u(\text { cert })}{\sqrt{6}}
$$

$\mu\left(V_{\text {pipeta }}\right)=$ Incerteza do volume em função de variações da vidraria ou micropipeta $(\mathrm{mL})$;

$u($ cert $)=$ Incerteza determinada no certificado da micropipeta;

$\sqrt{6}=$ assumindo distribuição triangular.

$$
\mu\left(V_{\text {pipeta }}\right)=\left(\frac{D P R}{100}\right) \cdot V
$$

Onde:

$\mu\left(V_{\text {pipeta }}\right)=$ Incerteza do volume em função de variações da vidraria ou micropipeta $(\mathrm{mL})$;

$C V$ = Coeficiente de Variação da Micropipeta, informada no certificado (DPR \%);

$V=$ Volume pipetado $(\mathrm{mL})$

$$
\mu\left(V_{\text {repe }}\right)=\left(\frac{s}{\sqrt{n}}\right)
$$

Onde:

$\mu\left(V_{\text {repe }}\right)=$ Incerteza do volume em função da repetitividade $(\mathrm{mL})$; $s$ = desvio padrão; 
$n=$ Número de replicatas.

Para cada uma das medidas, das alíquotas de amostra e dos ácidos, as incertezas foram combinadas conforme Equação 21.

$$
\mu\left(V_{X}\right)=\sqrt{\left(\mu\left(V_{\text {temp }}\right)\right)^{2}+\left(\mu\left(V_{\text {pipeta }}\right)\right)^{2}+\left(\mu\left(V_{\text {repe }}\right)\right)^{2}}
$$

Onde:

$\mu\left(V_{X}\right)=$ Incerteza do volume da alíquota medida $(\mathrm{mL}) ;$

A Incerteza padrão do volume final foi combinada conforme Equação 22.

$$
\mu(V)=\sqrt{\left(\mu\left(V_{a m 1}\right)\right)^{2}+\left(\mu\left(V_{a m 2}\right)\right)^{2}+\left(\mu\left(V_{H_{N O} O_{3}}\right)\right)^{2}\left(\mu\left(V_{H C l}\right)\right)^{2}}
$$

Onde:

$\mu(V)=$ Incerteza do volume final da amostra $(\mathrm{mL})$;

\subsubsection{Incerteza do Preparo da Curva Analítica}

Para o preparo da curva analítica é inicialmente preparada uma solução estoque (SE) multielementar a partir dos padrões certificados monoelementares, cada ponto da curva analítica é preparado utilizando a mesma SE. Na etapa de estimativa de incerteza do preparo da curva analítica cada uma destas etapas deve ser considerada.

Nesta etapa também é realizada a estimativa da incerteza padrão do volume, para esta etapa são consideradas a variação de volume em função da temperatura do laboratório $\left(3^{\circ} \mathrm{C}\right)$ variação de volume em função da vidraria e variação de volume em função da repetitividade. Também foi considerada a incerteza da concentração de cada padrão monoelementar, conforme apresentado no certificado de cada um dos padrões. Na Equação 23 pode ser observado como estas fontes de incerteza foram combinadas para a obtenção da incerteza de preparo da SE. 


$$
\mu\left(\text { Conc }_{S E}\right)=\left[\sqrt{\left(\frac{\mu V_{\text {pipet }}}{V_{\text {pipet }}}\right)^{2}+\left(\frac{\mu V_{\text {balão }}}{V_{\text {balão }}}\right)^{2}+\left(\frac{\mu \text { Conc }_{\text {padrão }}}{\text { Conc }_{\text {padrão }}}\right)^{2}}\right] \cdot \text { Conc }_{S E}
$$

Onde:

$\mu\left(\right.$ Conc $\left._{S E}\right)=$ incerteza da concentração da SE;

$\mu V_{\text {pipet }}=$ incerteza padrão do volume pipetado do padrão certificado;

$V_{\text {pipet }}=$ Volume pipetado do padrão;

$\mu V_{\text {balão }}=$ incerteza padrão do balão volumétrico;

$V_{\text {balão }}=$ Volume do balão volumétrico;

$\mu$ Conc $_{\text {padrão }}=$ incerteza padrão informada no certificado do padrão;

Conc $_{\text {padrão }}=$ Concentração do padrão informada no certificado;

$\operatorname{Conc}_{S E}=$ Concentração final do elemento na SE.

Na Equação 24 está apresentada a combinação das fontes de incerteza para a obtenção da incerteza de cada um dos pontos de cada curva analítica.

$$
\mu\left(\operatorname{Conc}_{P X}\right)=\left[\sqrt{\left(\frac{\mu V_{\text {pipet }}}{V_{\text {pipet }}}\right)^{2}+\left(\frac{\mu V_{\text {balão }}}{V_{\text {balão }}}\right)^{2}+\left(\frac{\mu \operatorname{Conc}_{S E}}{\operatorname{Conc}_{S E}}\right)^{2}}\right] \cdot \operatorname{Conc}_{P X}
$$

Onde:

$\mu\left(\right.$ Conc $\left._{P X}\right)=$ incerteza da concentração do Ponto;

$\mu V_{\text {pipet }}=$ incerteza padrão do volume pipetado da SE;

$V_{\text {pipet }}=$ Volume pipetado da SE;

$\mu V_{\text {balão }}=$ incerteza padrão do balão volumétrico;

$V_{\text {balão }}=$ Volume do balão volumétrico;

$\mu$ Conc $_{S E}=$ incerteza padrão da SE;

Conc $_{S E}=$ Concentração do elemento na SE;

$\operatorname{Conc}_{P X}=$ Concentração final do elemento no ponto.

Após a estimativa de incerteza para cada um dos pontos foi considerada a incerteza do preparo da curva analítica como o maior resultado obtido, 
transformado para porcentagem, para que deste modo a incerteza escolhida englobe qualquer ponto da curva analítica.

\subsubsection{Incerteza do Modelo da Curva Analítica}

A incerteza do modelo da curva analítica foi calculada conforme exemplo apresentado no Guia Eurachem (Equação 25).

$$
\mu\left(C_{X}\right)=\frac{S}{B_{1}}\left[\sqrt{\frac{1}{p}+\frac{1}{n}+\frac{\left(C_{X}-\bar{C}\right)}{S_{x x}}}\right]
$$

Onde:

$\mu\left(C_{X}\right)=$ Incerteza padrão da curva analítica no ponto $\mathrm{X}$;

$S$ = Desvio Padrão Residual;

$B_{1}=$ Inclinação da Curva de Calibração;

$p=$ número de medidas para determinar $C_{X}$;

$n=$ número de medidas para a curva analítica;

$C_{X}=$ Concentração do elemento na amostra;

$\bar{C}=$ média das calibrações;

$C_{i}=$ valor de calibração obtido a partir pela curva de calibração.

$S_{x x}=\sum_{i=1}^{n}\left(C_{i}-\bar{C}\right)^{2}$

\subsubsection{Incerteza da Repetitividade do Método}

Para a estimativa de incerteza desta etapa também foram avaliadas as triplicatas da leitura das adições realizadas para as digestões das amostras coletadas em 2013 e 2014. Foram eliminados valores considerados discrepantes, e para a determinação da incerteza da repetitividade foi utilizada a Equação 26. 


$$
\mu(\text { Repe })=\left(\frac{\text { Máx } D P R}{\sqrt{n}}\right)
$$

Onde:

Máx $D P R=$ Maior DPR do intervalo de valores;

$n=$ número de valores do intervalo.

\subsubsection{Incerteza da Recuperação do Método}

Para esta avaliação foram utilizados os resultados das adições realizadas para as digestões das amostras coletadas em 2013 e 2014. Inicialmente foram eliminados valores considerados discrepantes e calculada a média da recuperação do método para cada elemento. Posteriormente foi calculada a incerteza da recuperação do método conforme Equação 27.

$$
\mu(\operatorname{Rec})=\left(\frac{\overline{\operatorname{Rec}}}{\sqrt{s}}\right)
$$

Onde:

$\overline{\operatorname{Rec}}=$ Média da Recuperação do método para o elemento; $s=$ Desvio padrão da recuperação.

O guia Eurachem aconselha realizar o teste $\mathrm{t}$ para verificar se a recuperação é significativamente diferente de 100\%, de modo que seja possível decidir se este fator será ou não incluído no modelo matemático, mas para fins de padronização do modelo matemático e também do método de estimativa de incerteza, a realização do teste t foi desconsiderada e a recuperação do método foi considerada para todos os elemento. 


\subsubsection{Combinação e Expansão das Incertezas}

Com base no diagrama de Ishikawa foi possível realizar o levantamento de todas as fontes de incerteza que contribuem para o método estudado, e as incertezas foram combinadas utilizando a Equação 28.

$$
\mu\left(\operatorname{Conc}_{A m}\right)=\left[\sqrt{\left(\frac{\mu V}{V}\right)^{2}+\left(\frac{\mu P X}{100}\right)^{2}+\left(\frac{\mu C_{X}}{C x}\right)^{2}+\left(\frac{\mu R e p e}{100}\right)^{2}+\left(\frac{\mu R e c}{100}\right)^{2}}\right] \cdot \operatorname{Conc}_{A m}
$$

Onde:

$\mu V=$ Incerteza padrão de volume $(\mathrm{mL})$;

$V=$ volume total $(\mathrm{mL})$;

$\mu P X=$ Maior incerteza padrão dos pontos da curva analítica (\%);

$\mu C_{X}=$ Incerteza padrão do ajuste da curva analítica $\left(\mathrm{mg} \cdot \mathrm{L}^{-1}\right)$;

$C x=$ Concentração de um ponto da curva analítica $\left(\mathrm{mg}^{\mathrm{L}} \mathrm{L}^{-1}\right)$;

$\mu R e p e=$ Incerteza padrão da repetitividade (\%);

$\mu R e c=$ Incerteza padrão da Recuperação (\%);

Conc $_{A m}=$ Concentração da Amostra $\left(\mathrm{mg} \cdot \mathrm{L}^{-1}\right)$.

Após a combinação das incertezas foi realizada a expansão da mesma utilizando fator de abrangência $k=2$, considerando $95 \%$ de confiança dos resultados emitidos [112].

Para a avaliação de cada uma das fontes de incerteza foi realizada análise gráfica da contribuição de cada fonte de incerteza. 


\section{RESULTADOS E DISCUSSÃO}

Neste capítulo são apresentados os resultados obtidos nos testes aplicados na avaliação dos parâmetros de validação de metodologia analítica.

\subsection{Faixa de Trabalho}

Avaliando o histórico de resultados de análises do efluente do IPEN no PMA-Q (nos anos de 2013 e 2014) e os valores estabelecidos pela legislação ambiental, as faixas de trabalho a serem estudadas neste trabalho foram definidas. Conforme pode ser visto na FIG. 19, FIG. 20 e FIG. 21 para os elementos Ba, Sn, $\mathrm{Cr}$, $\mathrm{Cu}$ e $\mathrm{Pb}$ foram mantidos na faixa de trabalho a concentração máxima encontrada no efluente no histórico de resultados e também o valor estabelecido pela legislação ambiental. Para os elementos $\mathrm{B}, \mathrm{Cd}$ e Fe somente foi mantido na faixa de trabalho o valor máximo obtido no histórico de análises, uma vez que concentrações altas como as definidas pela legislação ambiental nunca foram observadas. Para os elementos $\mathrm{Mn}$, Ni e $\mathrm{Zn}$ não foram mantidos na faixa de trabalho nem os valores definidos de pela legislação ambiental nem mesmo o valor máximo estabelecido pela legislação uma vez que concentrações altas foram esporádicas, caso resultados acima da faixa de trabalho sejam observados 0 analista deverá proceder a diluição das amostras.

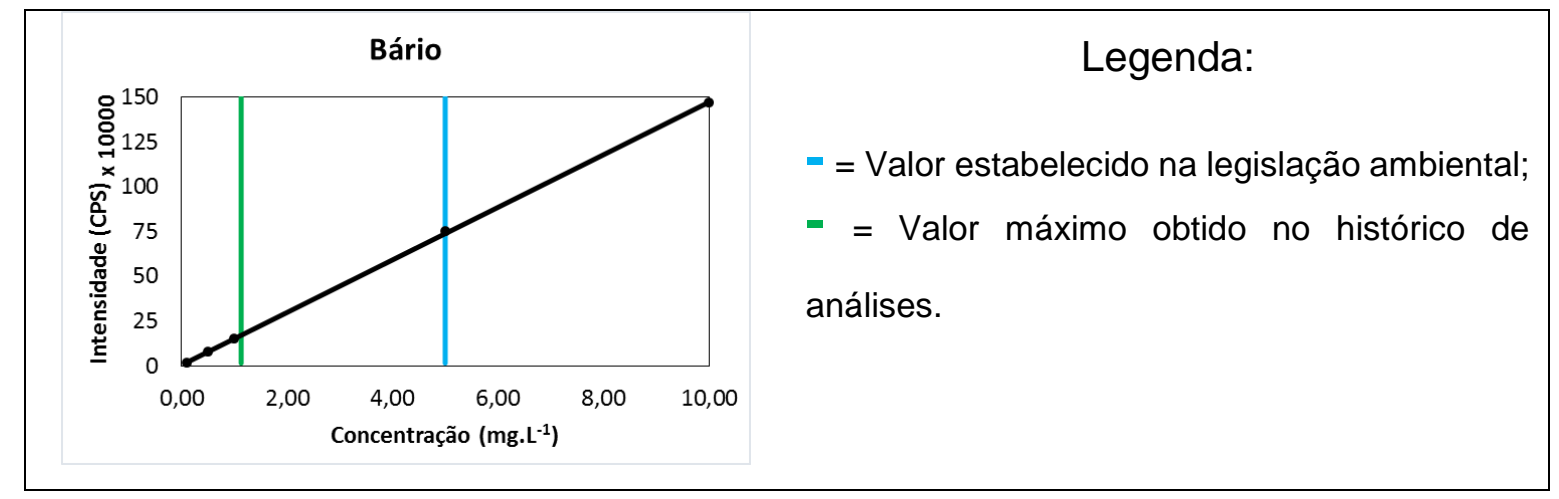

FIGURA 19: Demonstração da faixa de trabalho definida para o elemento $\mathrm{Ba}$ 


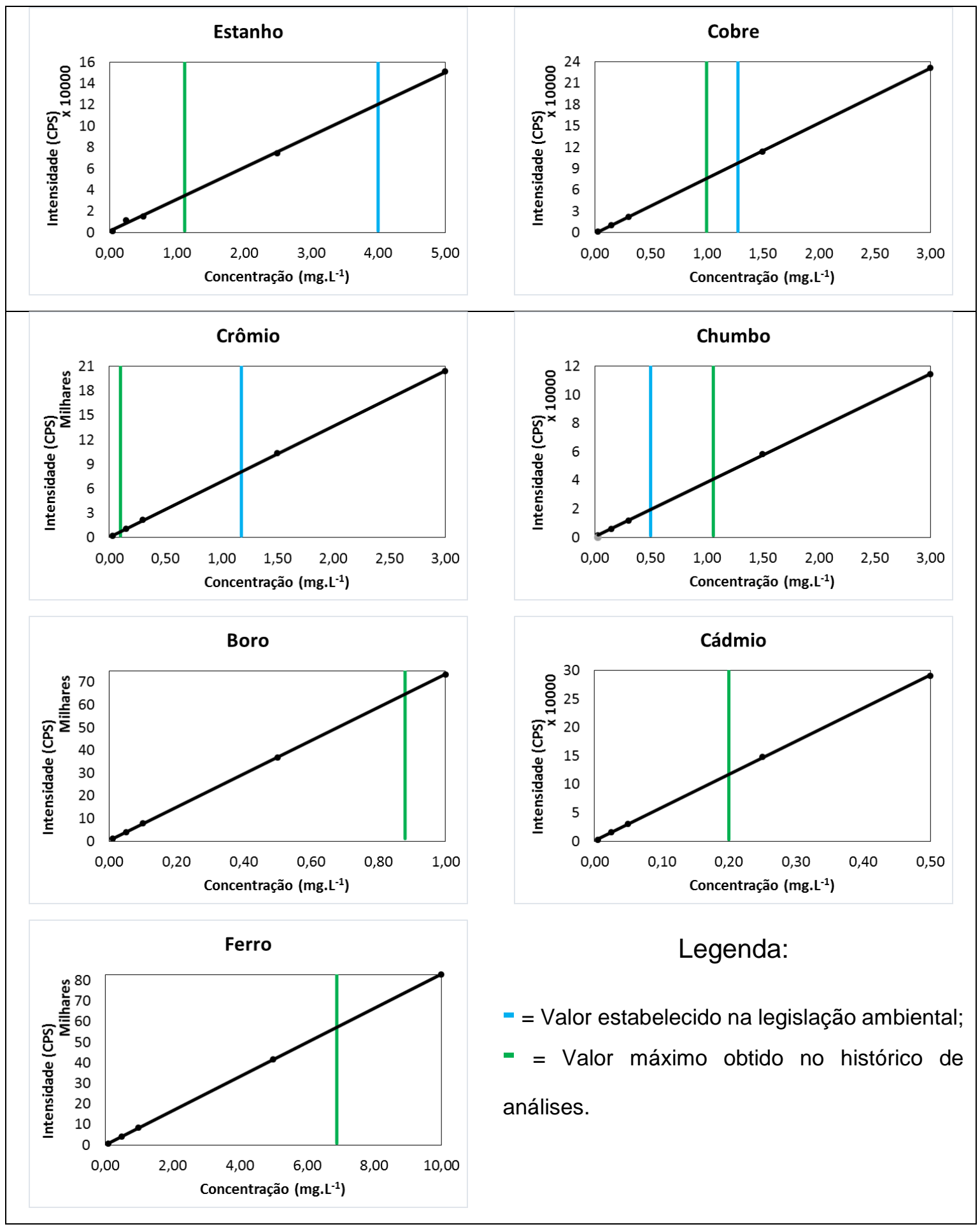

FIGURA 20: Demonstração da faixa de trabalho definida para os elementos Sn, $\mathrm{Cu}, \mathrm{Cr}, \mathrm{Pb}, \mathrm{B}, \mathrm{Cd}$ e $\mathrm{Fe}$ 


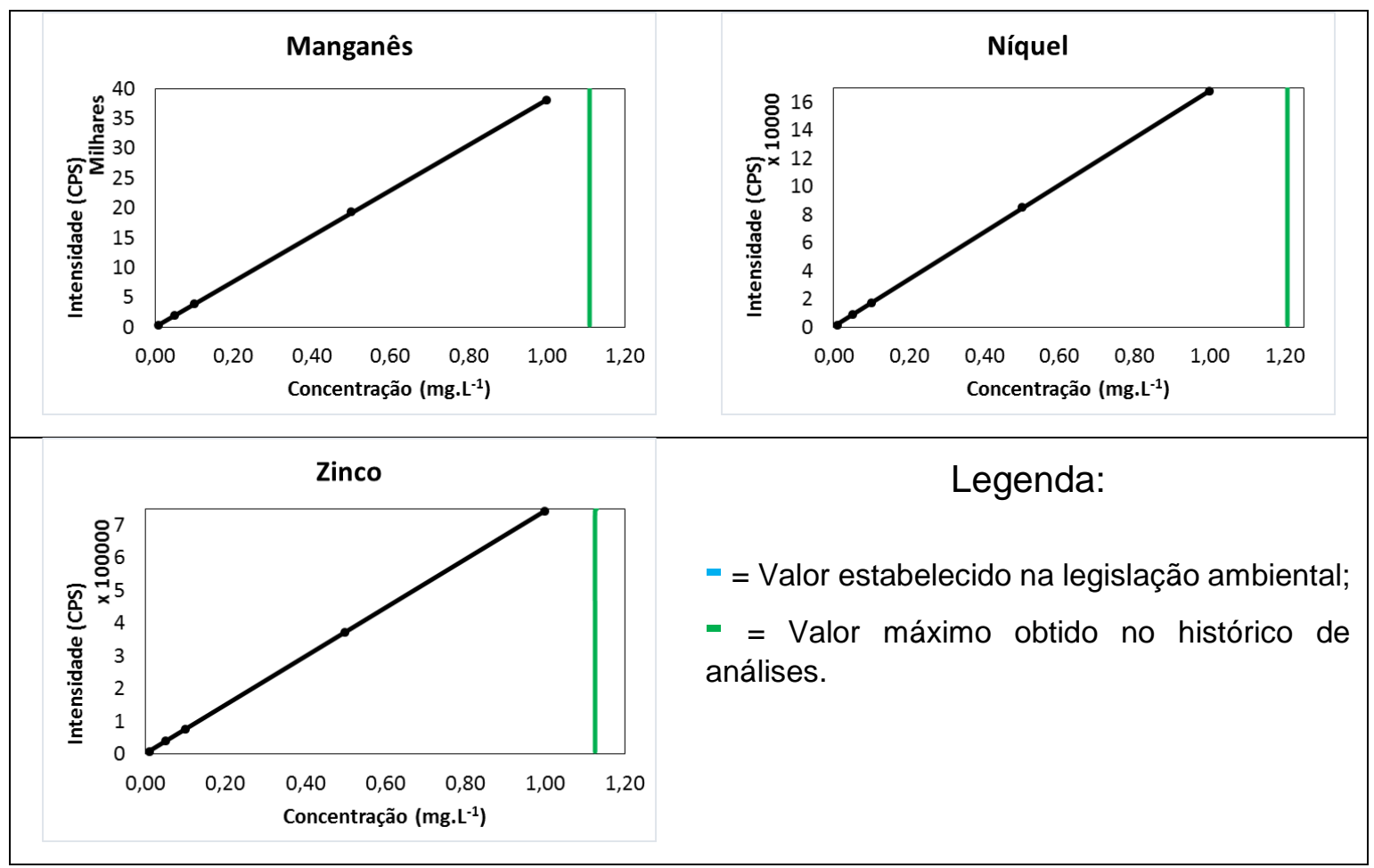

FIGURA 21: Demonstração da faixa de trabalho definida para os elementos $\mathrm{Mn}$,

\section{$\mathrm{Ni}$ e $\mathrm{Zn}$}

Os pontos definidos para a curva analítica de todos os elementos estudados estão apresentados na TAB. 9 e foram escolhidos de modo que estivessem bem distribuídos ao longo da faixa de trabalho definida, e também fosse possível utilizar a mesma solução estoque para a diluição e obtenção de todos os pontos, o que confere maior padronização das incertezas contribuintes, e diminuição da falta de correlação entre os pontos. 
TABELA 9: Faixa de trabalho e concentração das soluções padrão multielementares para construção da curva analítica

\begin{tabular}{ccccccc}
\hline Padrão & $\begin{array}{c}\mathbf{B} \\
\mathbf{m g} \cdot \mathbf{L}^{-1}\end{array}$ & $\begin{array}{c}\mathbf{S n} \\
\mathbf{m g} \cdot \mathbf{L}^{-1}\end{array}$ & $\begin{array}{c}\mathbf{C d} \\
\mathbf{m g} \cdot \mathbf{L}^{-1}\end{array}$ & $\begin{array}{c}\mathbf{B a} \\
\mathbf{m g} \cdot \mathbf{L}^{-1}\end{array}$ & $\begin{array}{c}\mathbf{C r} \\
\mathbf{m g} \cdot \mathbf{L}^{-1}\end{array}$ & $\begin{array}{c}\mathbf{C u} \\
\mathbf{m g} \cdot \mathbf{L}^{-1}\end{array}$ \\
\hline $\mathbf{1}$ & 0,010 & 0,050 & 0,005 & 0,100 & 0,030 & 0,030 \\
$\mathbf{2}$ & 0,050 & 0,250 & 0,025 & 0,500 & 0,150 & 0,150 \\
$\mathbf{3}$ & 0,100 & 0,500 & 0,050 & 1,000 & 0,300 & 0,300 \\
$\mathbf{4}$ & 0,500 & 2,500 & 0,025 & 5,000 & 1,500 & 1,500 \\
$\mathbf{5}$ & 1,000 & 5,000 & 0,050 & 10,000 & 3,000 & 3,000 \\
\hline & $\mathbf{F e}$ & $\mathbf{M n}$ & $\mathbf{N i}$ & $\mathbf{P b}$ & $\mathbf{Z n}$ & \\
& $\mathbf{m g} \cdot \mathbf{L}-\mathbf{1}$ & $\mathbf{m g} \cdot \mathbf{L}^{-1}$ & $\mathbf{m g} \cdot \mathbf{L}^{-1}$ & $\mathbf{m g} \cdot \mathbf{L}^{-1}$ & $\mathbf{m g} \cdot \mathbf{L}^{-1}$ & \\
\hline $\mathbf{1}$ & 0,100 & 0,010 & 0,010 & 0,030 & 0,010 & \\
$\mathbf{2}$ & 0,500 & 0,050 & 0,050 & 0,150 & 0,050 & \\
$\mathbf{3}$ & 1,000 & 0,100 & 0,100 & 0,300 & 0,100 & \\
$\mathbf{4}$ & 5,000 & 0,500 & 0,500 & 1,500 & 0,500 & \\
$\mathbf{5}$ & 10,000 & 1,000 & 1,000 & 3,000 & 1,000 & \\
\hline
\end{tabular}

Posteriormente, foram definidas as linhas espectrais a serem utilizadas para a análise dos elementos. As linhas foram definidas com base na sensibilidade para detecção do analito, ocorrência de interferências no estudo da seletividade, experiência do analista com a realização das análises, além de consulta à literatura [122]. As linhas definidas para a análise dos elementos estudados estão apresentadas na TAB. 10. 
TABELA 10: Linhas espectrais definidas

\begin{tabular}{cccccc}
\hline Elemento & $\begin{array}{c}\text { Linha } \\
\text { espectral }\end{array}$ & Elemento & $\begin{array}{c}\text { Linha } \\
\text { espectral }\end{array}$ & Elemento & $\begin{array}{c}\text { Linha } \\
\text { espectral }\end{array}$ \\
\hline $\mathrm{B}$ & 182,590 & $\mathrm{Cr}$ & 267,716 & $\mathrm{Ni}$ & 231,604 \\
$\mathrm{Sn}$ & 181,120 & $\mathrm{Cu}$ & 324,754 & $\mathrm{~Pb}$ & 220,353 \\
$\mathrm{Cd}$ & 214,438 & $\mathrm{Fe}$ & 259,940 & $\mathrm{Zn}$ & 213,856 \\
$\mathrm{Ba}$ & 455,403 & $\mathrm{Mn}$ & 257,610 & & \\
\hline
\end{tabular}

\subsection{Seletividade}

Por tratar-se de uma matriz complexa, para a determinação da seletividade do método foram necessárias diversas etapas. A primeira destas etapas foi a avaliação dos espectros de possíveis interferentes na determinação dos analitos. Os elementos escolhidos para a realização desta avaliação foram $\mathrm{Ca}$, $\mathrm{Fe}, \mathrm{Al}$ e $\mathrm{Na}$, por serem elementos presentes em alta concentração no efluente e também por conta de seus amplos espectros de emissão.

Conforme pode ser visto na FIG. 22 e na FIG. 23, verifica-se que na linha espectral dos elementos estudados, é possível identificar o pico do analito, formado mediante a leitura do padrão mais concentrado da curva analítica ( $P 1)$, e o branco bem como os elementos majoritários apresentam comportamento como linha de base, o que demonstra que não houve a ocorrência de interferências dos elementos avaliados nas linhas espectrais escolhidas. No espectro do alumínio construído para a avaliação da linha escolhida para a análise de chumbo, é possível observar algumas perturbações, o que demonstra a ocorrência de interferências, mas a linha espectral foi mantida já que a interferência foi observada para concentração de $50 \mathrm{mg} \cdot \mathrm{L}^{-1}$ de $\mathrm{Al}$ e no efluente do IPEN a concentração de Al não apresenta valores superiores a $10 \mathrm{mg} \cdot \mathrm{L}^{-1}$. Também pode-se observar que não houve deslocamento dos picos nem mesmo elevação do "background" para os elementos avaliados, o que demonstra a ausência de interferências nas linhas espectrais escolhidas. 


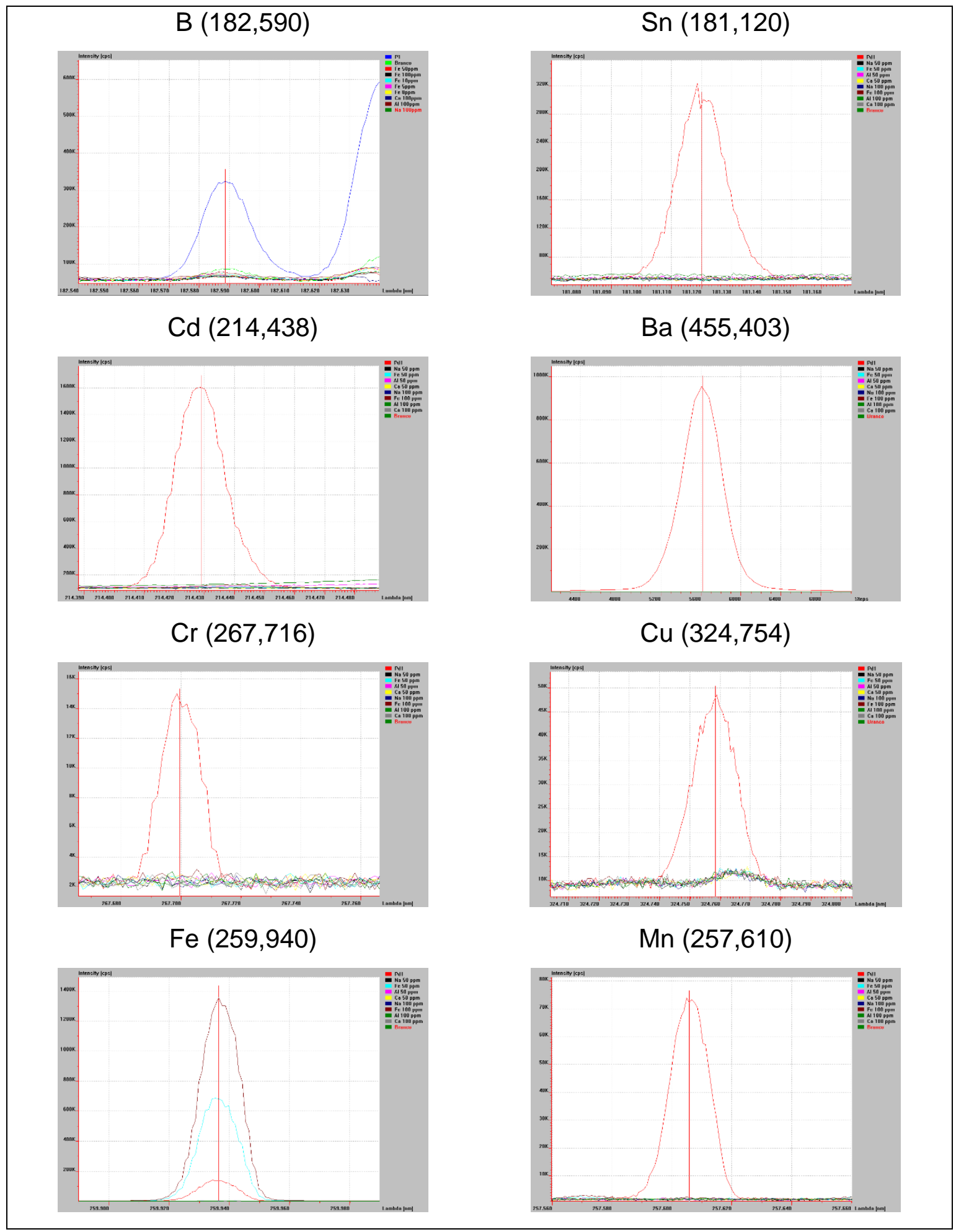

FIGURA 22: Espectros os elementos $\mathrm{Ca}, \mathrm{Fe}, \mathrm{Al}$ e $\mathrm{Na}$ nas linhas espectrais escolhidas para análise dos elementos $\mathrm{B}, \mathrm{Sn}, \mathrm{Cd}, \mathrm{Ba}, \mathrm{Cr}, \mathrm{Cu}, \mathrm{Fe}$ e $\mathrm{Mn}$. 


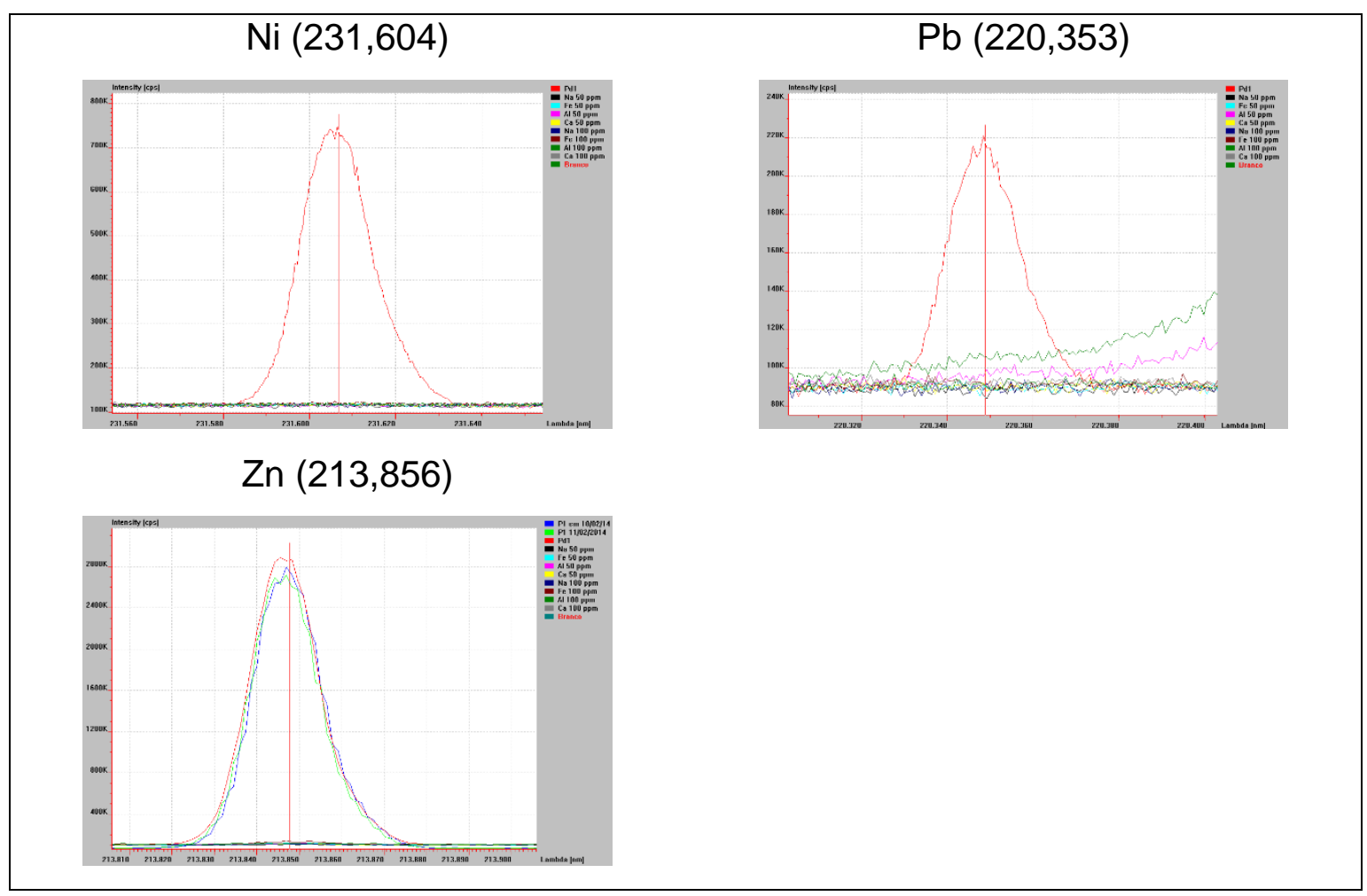

FIGURA 23: Espectros os elementos $\mathrm{Ca}, \mathrm{Fe}, \mathrm{Al}$ e $\mathrm{Na}$ nas linhas espectrais escolhidas para análise dos elementos $\mathrm{Ni}, \mathrm{Pb}$ e $\mathrm{Zn}$

Pequenas variações podem ser observadas na linha de base dos espectros avaliados e podem ter ocorrido por conta da influência do ácido $\left(\mathrm{HNO}_{3}\right)$ presente no meio ou pequenas contaminações da água ou da vidraria. Estas pequenas variações não apresentam influência na determinação dos analitos, uma vez que apresentam sinal abaixo do limite de detecção do equipamento.

Após a avaliação dos espectros foram construídas as curvas analíticas com e sem matriz (FIG. 24 e FIG. 25). A curva com matriz foi analisada e posteriormente a média do branco da amostra foi subtraído de cada ponto, pois este continha baixa concentração dos analitos.

Avaliando os gráficos é possível observar que houveram pequenas variações na inclinação das curvas estudadas, principalmente nos pontos mais concentrados, mas a faixa de trabalho foi mantida para que o objetivo do método analítico fosse atendido. Outros testes foram realizados para avaliar a amplitude desta diferença de sensibilidade. 


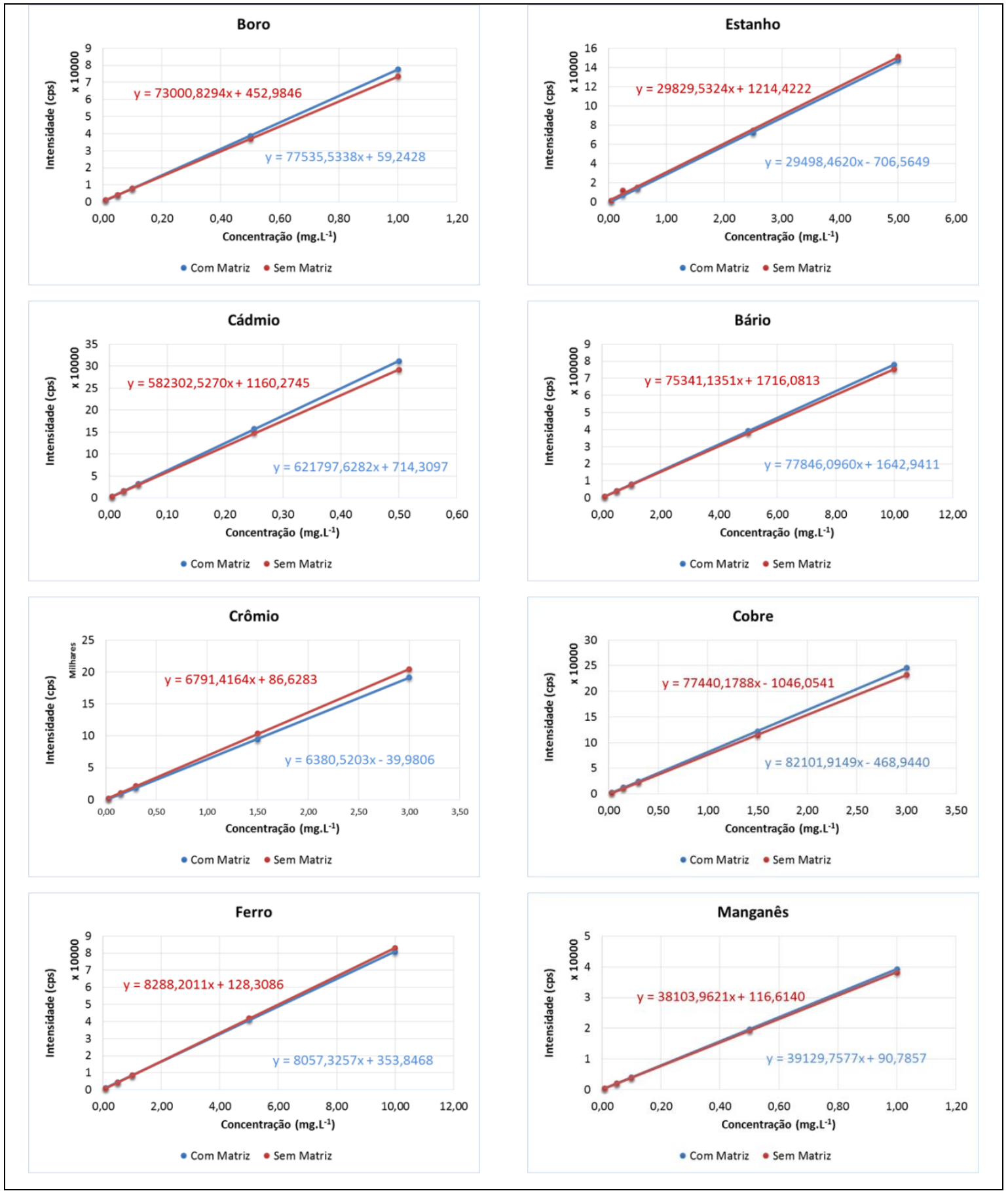

FIGURA 24: Curvas analíticas com matriz e sem matriz dos elementos $\mathrm{B}, \mathrm{Sn}$, $\mathrm{Cd}, \mathrm{Ba}, \mathrm{Cr}, \mathrm{Cu}, \mathrm{Fe}$ e $\mathrm{Mn}$ 


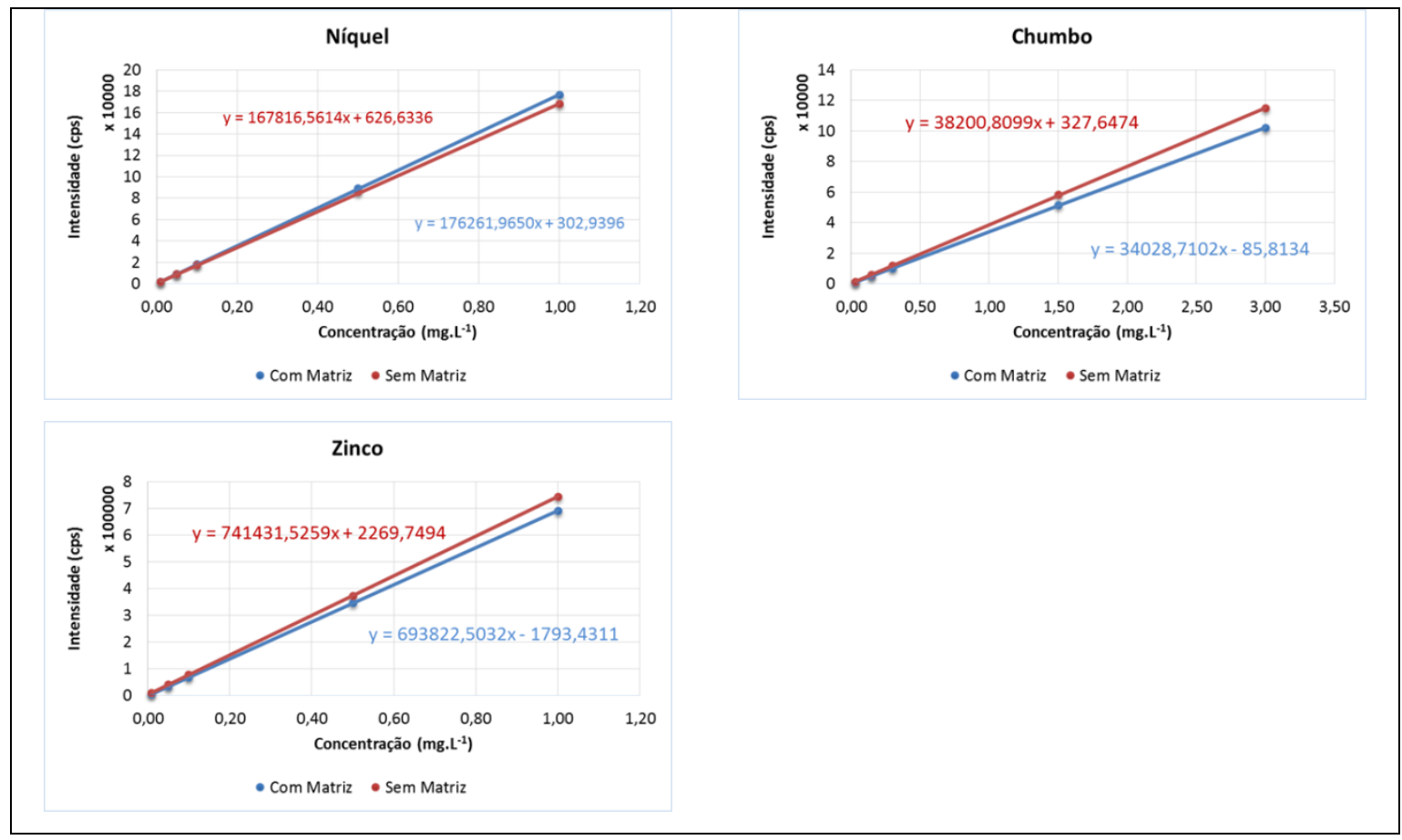

FIGURA 25: Curvas Analíticas com matriz e sem matriz dos elementos $\mathrm{Ni}, \mathrm{Pb}$ e $\mathrm{Zn}$

Para evidenciar a equivalência das curvas analíticas com e sem matriz apresentadas acima, foi realizado o teste de F de Snedcor para a Sensibilidade de 10 replicatas das curvas analíticas com e sem matriz. Assim foi possível avaliar se a variação da sensibilidade entre as curvas analíticas com e sem matriz, também está compreendida na variação dentro de cada grupo. Para que os resultados sejam considerados satisfatórios neste teste, $\mathrm{F}$ calculado deve ser menor que $\mathrm{F}$ crítico. Avaliando os resultados apresentados na TAB. 11, é possível verificar que para $F$ crítico $3,1800(n=10)$ todos os resultados obtidos foram considerados satisfatórios.

TABELA 11: Teste F para sensibilidades das curvas com e sem matriz

\begin{tabular}{cccccc}
\hline Elemento & F calc. & Elemento & F calc. & Elemento & F calc. \\
\hline $\mathrm{B}$ & 3,0215 & $\mathrm{Cr}$ & 0,4765 & $\mathrm{Ni}$ & 0,5464 \\
$\mathrm{Sn}$ & 1,0820 & $\mathrm{Cu}$ & 3,0097 & $\mathrm{~Pb}$ & 0,9060 \\
$\mathrm{Cd}$ & 2,3084 & $\mathrm{Fe}$ & 1,9461 & $\mathrm{Zn}$ & 1,8866 \\
$\mathrm{Ba}$ & 1,4503 & $\mathrm{Mn}$ & 1,0045 & & \\
\hline
\end{tabular}

F crítico $=3,1800$, para $\alpha=0,05$ e $n=10$. 


\section{$9.3 \quad$ Linearidade}

Para a avaliação da linearidade foram utilizados os dados das curvas analíticas sem matriz, já que as curvas com e sem matriz mostraram-se equivalentes no estudo da seletividade.

Incialmente foi realizada a análise de resíduos para avaliação do desvio da linearidade (resultados apresentados na TAB. 12), e é possível verificar que alguns pontos excederam o valor de $t$ crítico $(t$ crítico $=2,776$ para $\alpha=0,05$ e $n=$ 5), indicando que estes pontos não fazem parte da reta. Porém outros fatores devem ser levados em consideração antes que os pontos sejam excluídos da curva analítica, impactando no método de quantificação dos elementos.

Avaliando os cálculos realizados para este teste, é possível verificar que o teste $\mathrm{t}$ considera o mesmo fator de satisfação para as concentrações mais baixas e mais altas da curva analítica, e também tem como base para a realização dos cálculos o desvio padrão dos resíduos de todos os pontos como um conjunto, assim pode-se considerar este teste um tanto quanto conservador para a variação de concentração dos pontos mais altos da curva analítica, tal que as variações de concentração observadas não foram determinadas como significantes para o detrimento do modelo linear. Assim os pontos foram mantidos e foi dado andamento no estudo da linearidade.

Avaliando o r, também chamado de coeficiente de correlação (TAB. 13), é possível verificar que todas as curvas apresentaram resultados acima do considerado como aceitável pelo INMETRO [112], que é de $r \geq 0,9$. Este coeficiente indica 0 nível de correlação entre as intensidades e suas respectivas concentrações, e é um fator de extrema importância na aceitação das curvas analíticas [110]. 
TABELA 12: Teste t para desvio da linearidade

\begin{tabular}{ccccccc}
\hline Padrão & $\mathbf{B}$ & $\mathbf{S n}$ & $\mathbf{C d}$ & $\mathbf{B a}$ & $\mathbf{C r}$ & $\mathbf{C u}$ \\
\hline 1 & 2,721 & 0,987 & 1,583 & 1,641 & 2,054 & 1,910 \\
2 & 0,029 & 0,851 & 0,493 & 0,761 & 0,682 & 0,341 \\
3 & 1,358 & 0,155 & 0,195 & 0,599 & 1,130 & 0,475 \\
4 & 2,887 & 3,851 & 3,719 & 3,616 & 3,328 & 3,574 \\
5 & 1,554 & 1,857 & 1,839 & 1,814 & 1,722 & 1,799 \\
\hline Padrão & $\mathbf{F e}$ & $\mathbf{M n}$ & $\mathbf{N i}$ & $\mathbf{P b}$ & $\mathbf{Z n}$ & \\
\hline 1 & 1,599 & 2,046 & 1,028 & 1,639 & 2,633 & \\
2 & 0,332 & 0,161 & 1,392 & 0,677 & 0,012 & \\
3 & 0,034 & 0,464 & 0,566 & 0,492 & 1,213 & \\
4 & 3,735 & 3,522 & 3,663 & 3,646 & 3,007 & \\
5 & 1,838 & 1,779 & 1,808 & 1,822 & 1,599 & \\
\hline
\end{tabular}

t crítico $=2,776$ para $\alpha=0,05$ e $n=5$;

TABELA 13: Coeficiente de correlação das curvas segundo o software Smart Analyzer da Spectro

\begin{tabular}{cccccc}
\hline $\mathbf{B}$ & $\mathbf{S n}$ & $\mathbf{C d}$ & $\mathbf{B a}$ & $\mathbf{C r}$ & $\mathbf{C u}$ \\
\hline 1,0000 & 0,9999 & 1,0000 & 1,0000 & 0,9999 & 0,9999 \\
\hline $\mathbf{F e}$ & $\mathbf{M n}$ & $\mathbf{N i}$ & $\mathbf{P b}$ & $\mathbf{Z n}$ & \\
\hline 1,0000 & 1,0000 & 1,0000 & 1,0000 & 1,0000 & \\
\hline
\end{tabular}

$\mathrm{R}$ satisfatório $\geq 0,9$.

Também pode ser observado o comportamento linear das curvas analíticas avaliando as curvas sem matriz da FIG. 24 e FIG. 25. Em complemento à análise visual, foram avaliados os resíduos absolutos das curvas analíticas (FIG. 26 e FIG. 27). Caso a análise de resíduos seja realizada por concentração é possível verificar que os pontos apresentam alta dispersão, notadamente nos últimos pontos da curva, o que é considerado normal em virtude do aumento das concentrações. 


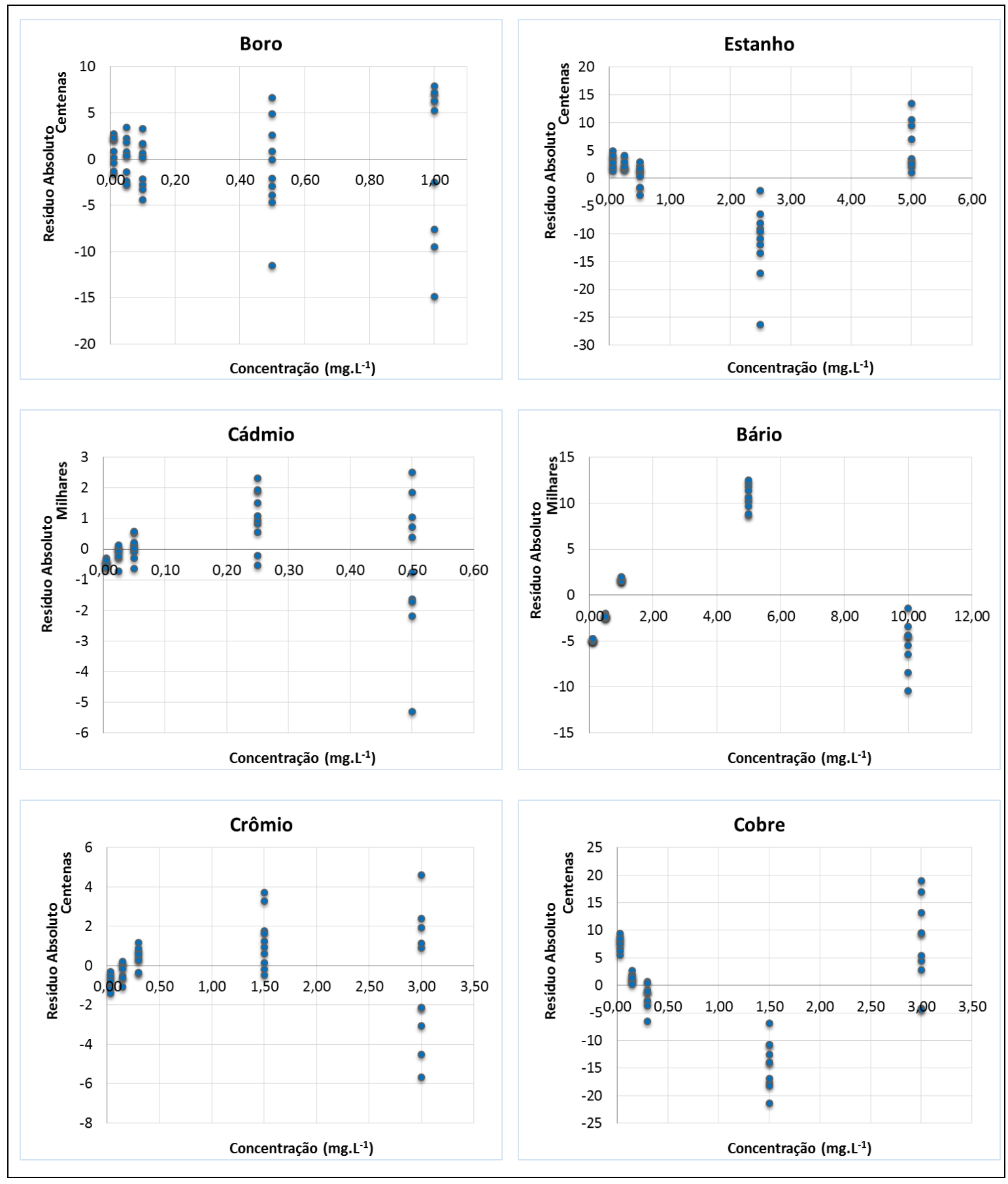

FIGURA 26: Distribuição dos resíduos absolutos por concentração dos elementos $\mathrm{B}, \mathrm{Sn}, \mathrm{Cd}, \mathrm{Ba}, \mathrm{Cr}$ e $\mathrm{Cu}$ 


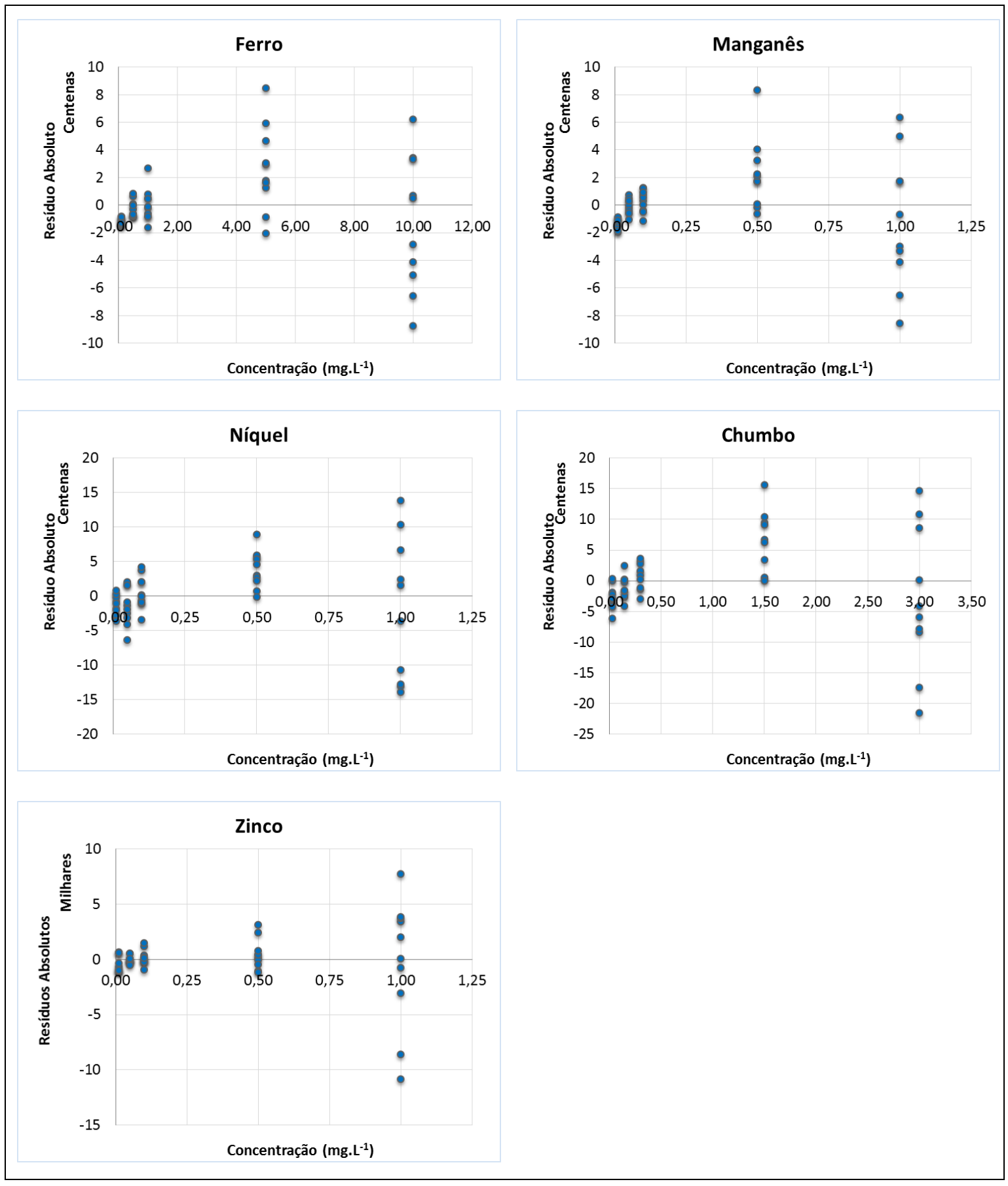

FIGURA 27: Distribuição dos resíduos absolutos por concentração do elemento $\mathrm{Fe}, \mathrm{Mn}, \mathrm{Ni}, \mathrm{Pb}$ e $\mathrm{Zn}$

No entanto, conforme pode ser visto na TAB. 14 o maior resíduo observado em cada um dos gráficos acima representa uma pequena porcentagem da maior intensidade observada nas curvas analíticas sem matriz, o que demonstra uma dispersão considerada insignificante, corroborando com o modelo linear proposto. 
TABELA 14: Resíduos das curvas analíticas

\begin{tabular}{cccc}
\hline Elemento & $\begin{array}{c}\text { Intensidade - Curva } \\
\text { Analítica (cps) }\end{array}$ & $\begin{array}{c}\text { Intensidade - } \\
\text { Resíduo Absoluto } \\
\text { (cps) }\end{array}$ & $\begin{array}{c}\text { Porcentagem de } \\
\text { Resíduo (\%) }\end{array}$ \\
\hline $\mathrm{B}$ & 147837,10 & 1342,00 & 0,91 \\
$\mathrm{Sn}$ & 314114,60 & 2501,48 & 0,80 \\
$\mathrm{Cd}$ & 816395,00 & 7727,51 & 0,95 \\
$\mathrm{Ba}$ & 38855,73 & 635,15 & 1,63 \\
$\mathrm{Cr}$ & 116395,79 & 1465,71 & 1,26 \\
$\mathrm{Cu}$ & 177950,30 & 1039,40 & 0,58 \\
$\mathrm{Fe}$ & 83631,37 & 621,05 & 0,74 \\
$\mathrm{Mn}$ & 233167,37 & 1892,88 & 0,81 \\
$\mathrm{Ni}$ & 20921,17 & 460,29 & 2,20 \\
$\mathrm{~Pb}$ & 752257,49 & 12481,97 & 1,66 \\
$\mathrm{Zn}$ & 78387,30 & 792,52 & 1,01 \\
\hline
\end{tabular}

Intensidade - Curva Analítica (cps) = Maior intensidade observada para a curva analítica; Intensidade - Resíduo Absoluto (cps) = Maior intensidade observada para os resíduos absolutos.

Também foi avaliada a distribuição dos resíduos normalizados (FIG. 28 e FIG. 29), pode-se verificar que os gráficos apresentam comportamento linear e a maioria dos pontos encontram-se distribuídos no intervalo de -2 a +2 , ou seja, \pm 2 desvios padrão, caracterizando 95\% de confiança. 


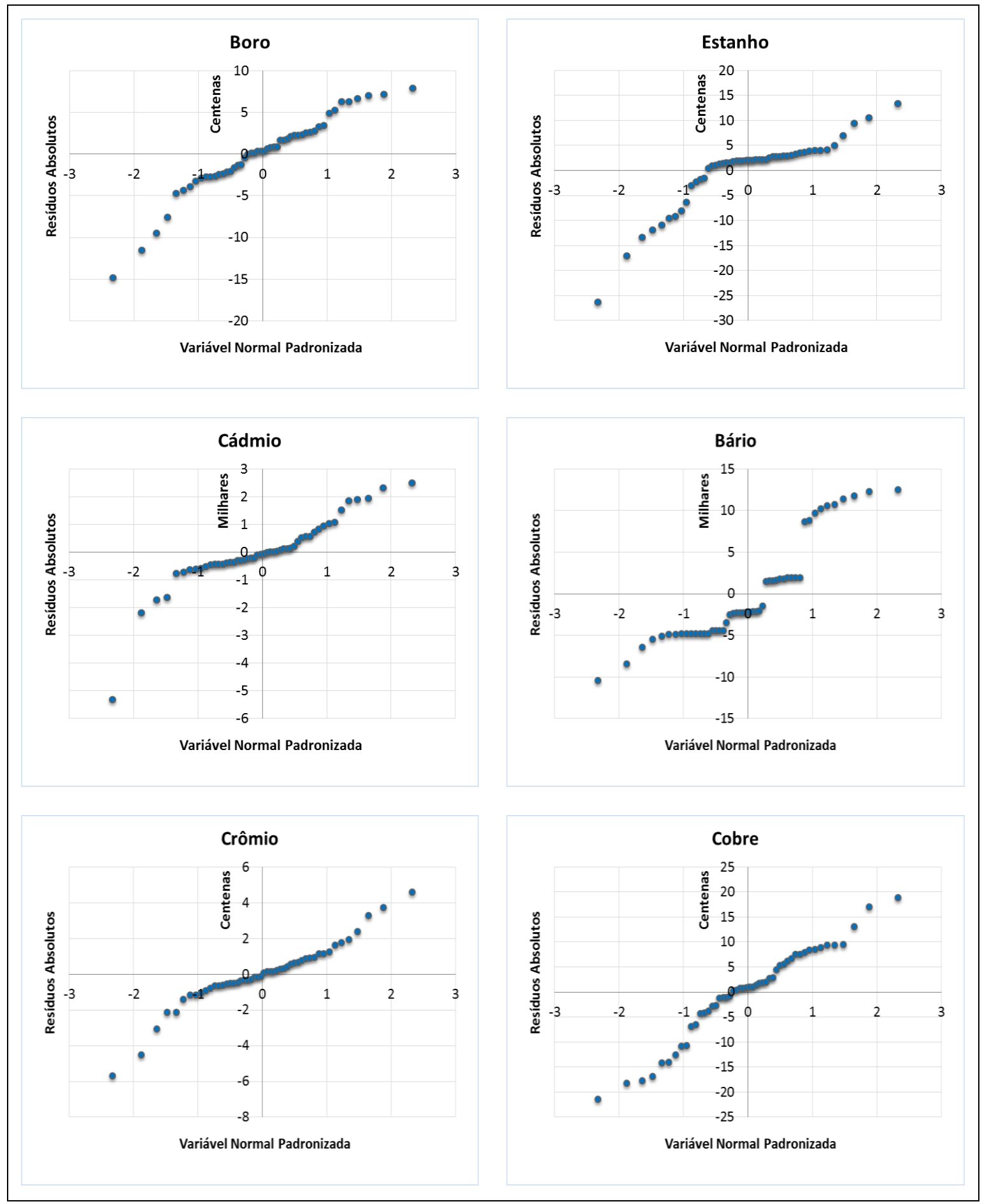

FIGURA 28: Gráfico da variável normal padronizada dos elementos B, Sn, Cd, $\mathrm{Ba}, \mathrm{Cr}$ e $\mathrm{Cu}$ 


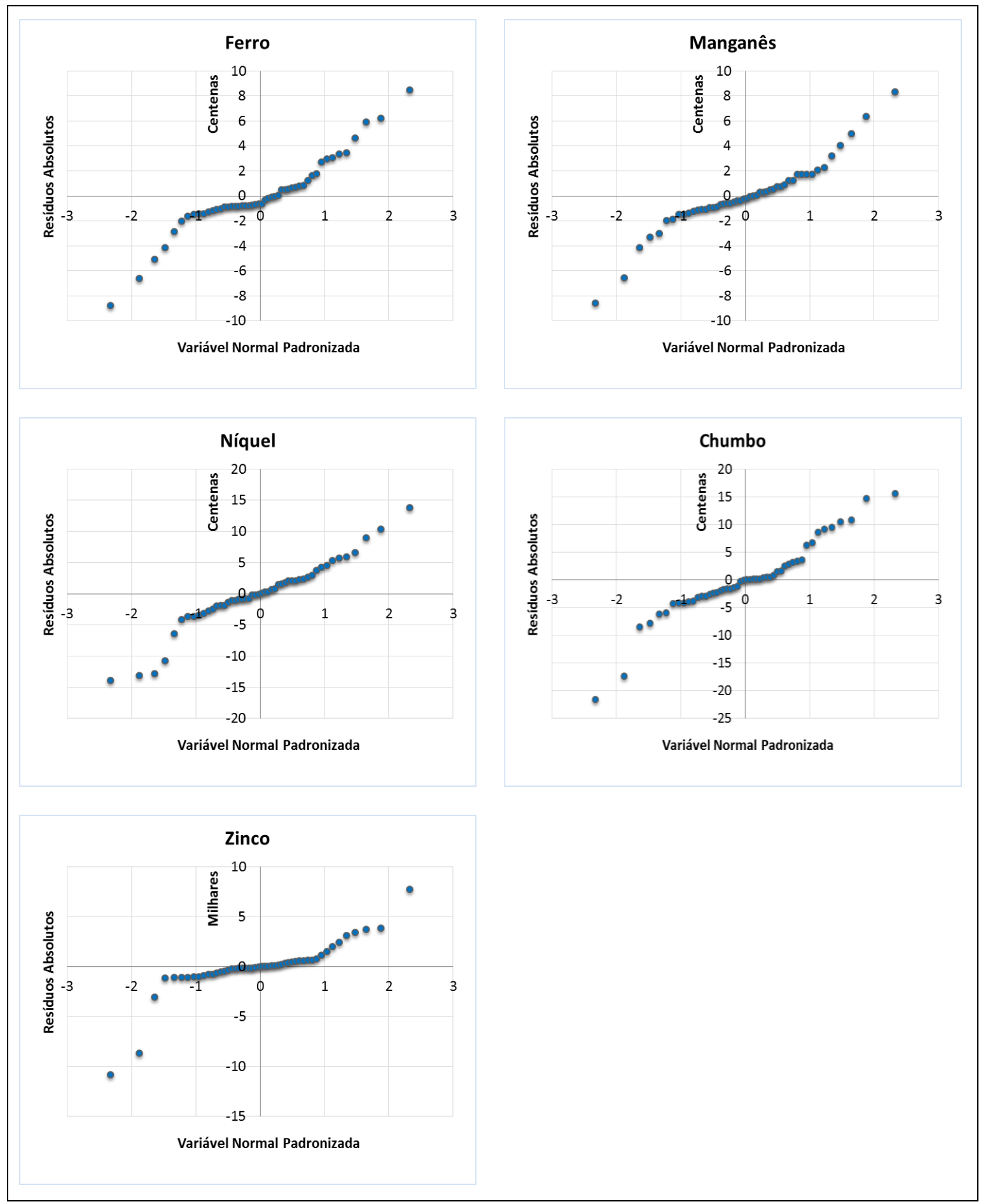

FIGURA 29: Gráfico da variável normal padronizada dos elementos $\mathrm{Fe}, \mathrm{Mn}, \mathrm{Ni}$, $\mathrm{Pb}$ e $\mathrm{Zn}$

Na TAB. 15 podem ser observados os resultados da ANOVA, pode-se verificar que o $\mathrm{F}$ calculado baseado na regressão e nos resíduos está acima do $\mathrm{F}$ crítico ( $F$ crítico 5,318 para $\alpha=0,05$ e de 1 a 8 graus de liberdade) para todos os elementos, evidenciado que as regressões são significativas. 
E o F calculado com base no Erro Puro e Falta de ajuste é menor que o $F$ crítico ( $F$ crítico $=5,409$ para $\alpha=0,05$ e de 3 a 5 graus de liberdade) para todos os elementos, demonstrando que não há falta de ajuste das regressões calculadas. E em complemento à estes resultados verifica-se que a porcentagem de variação explicada e explicável é de aproximadamente 100\% para todos os elementos, o que salienta alta correlação entre os pontos de todas as curvas analíticas.

TABELA 15: Resultados da Análise de Variância

\begin{tabular}{ccccc}
\hline Elemento & $\begin{array}{c}\text { Fcal da }_{\text {de }} \\
\text { Regressão }\end{array}$ & $\begin{array}{c}\text { F calc falta de }_{\text {ajuste }} \\
\text { Boro }\end{array}$ & $\begin{array}{c}\text { Variação } \\
\text { Explicada }\end{array}$ & $\begin{array}{c}\text { de } \\
\text { Variação } \\
\text { Explicável }\end{array}$ \\
\hline Estanho & 300835,80 & 3,17 & 100,00 & 100,00 \\
Cádmio & 35216,67 & 2,35 & 99,98 & 99,99 \\
Bário & 536749,16 & 4,36 & 99,98 & 99,98 \\
Crômio & 41320,53 & 1,40 & 100,00 & 100,00 \\
Cobre & 67138,19 & 3,50 & 99,98 & 99,99 \\
Ferro & 179553,20 & 1,90 & 99,99 & 100,00 \\
Manganês & 51432,94 & 0,33 & 100,00 & 100,00 \\
Níquel & 202884,06 & 0,61 & 99,98 & 99,99 \\
Chumbo & 60712,85 & 3,82 & 100,00 & 100,00 \\
Zinco & 357924,29 & 0,94 & 99,99 & 100,00 \\
\hline
\end{tabular}

F crítico da regressão $=5,318$ para $\alpha=0,05$ de 1 a 8 graus de liberdade;

$\mathrm{F}$ crítico da falta de ajuste $=5,409$ para $\alpha=0,05$ de 3 a 5 graus de liberdade.

Avaliando da FIG. 30 à FIG. 35 é possível observar o intervalo de confiança para a faixa de trabalho estudada, e é possível verificar que não houve grandes variações no intervalo de confiança mesmo nos extremos da curva analítica (concentrações mais baixas e mais altas da curva analítica), o que confere mais confiabilidade aos resultados obtidos pelo método analítico. 


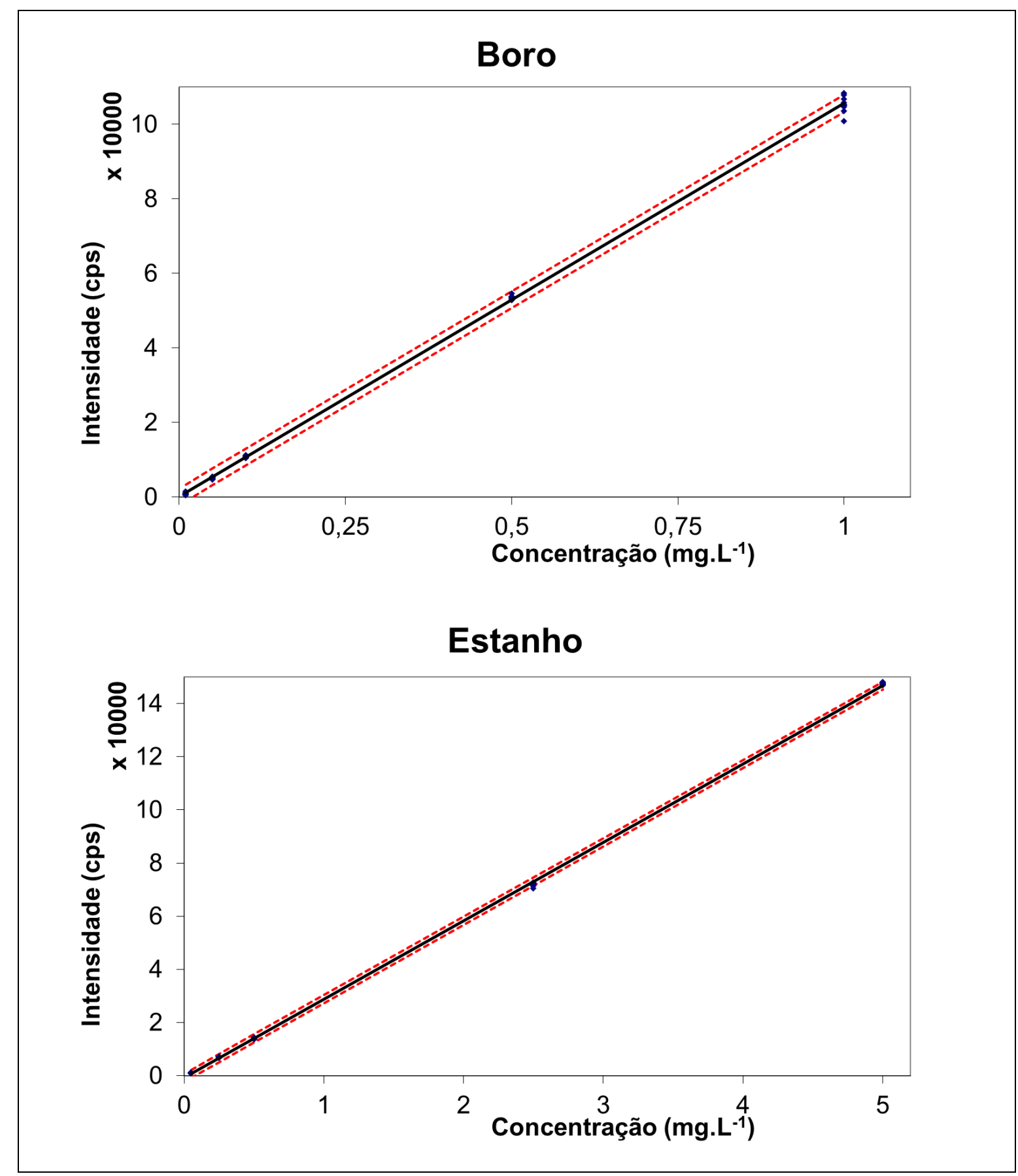

FIGURA 30: Resultados de intervalo de confiança de $95 \%$ para as faixas de trabalho dos elementos $\mathrm{B}$ e $\mathrm{Sn}$ 


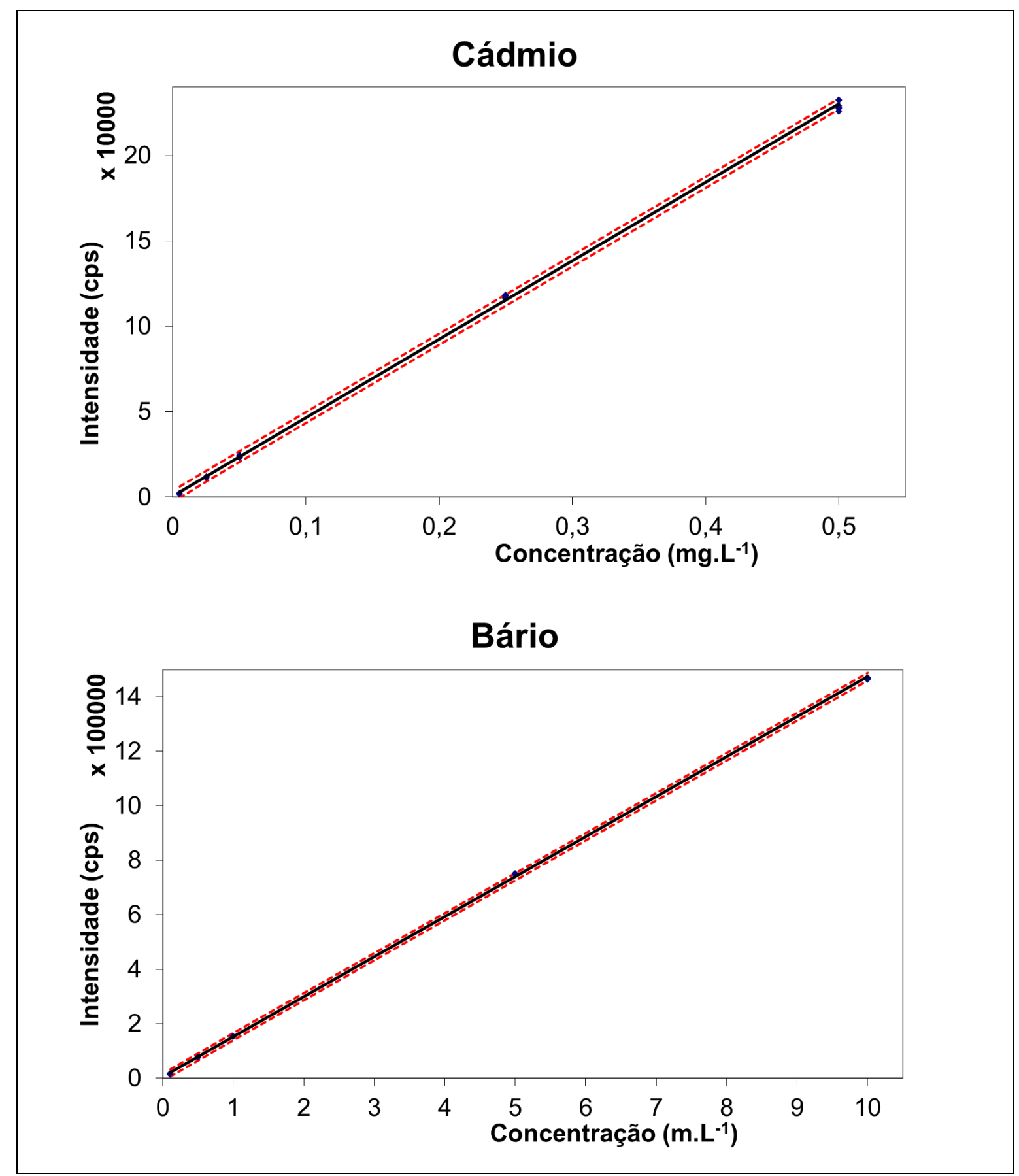

FIGURA 31: Resultados de intervalo de confiança de 95\% para as faixas de trabalho dos elementos $\mathrm{Cd}$ e $\mathrm{Ba}$ 


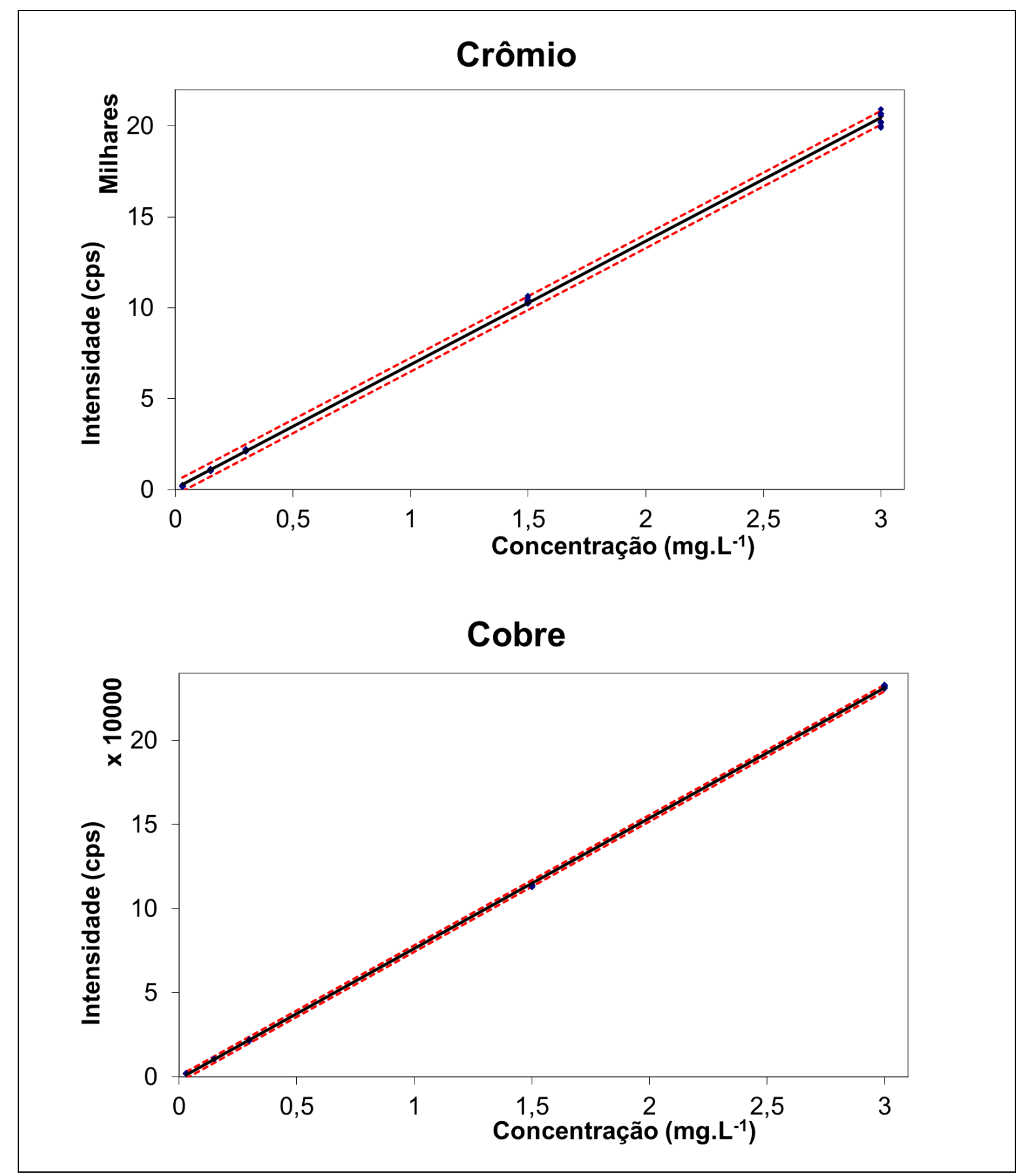

FIGURA 32: Resultados de intervalo de confiança de $95 \%$ para as faixas de trabalho dos elementos $\mathrm{Cr}$ e $\mathrm{Cu}$ 


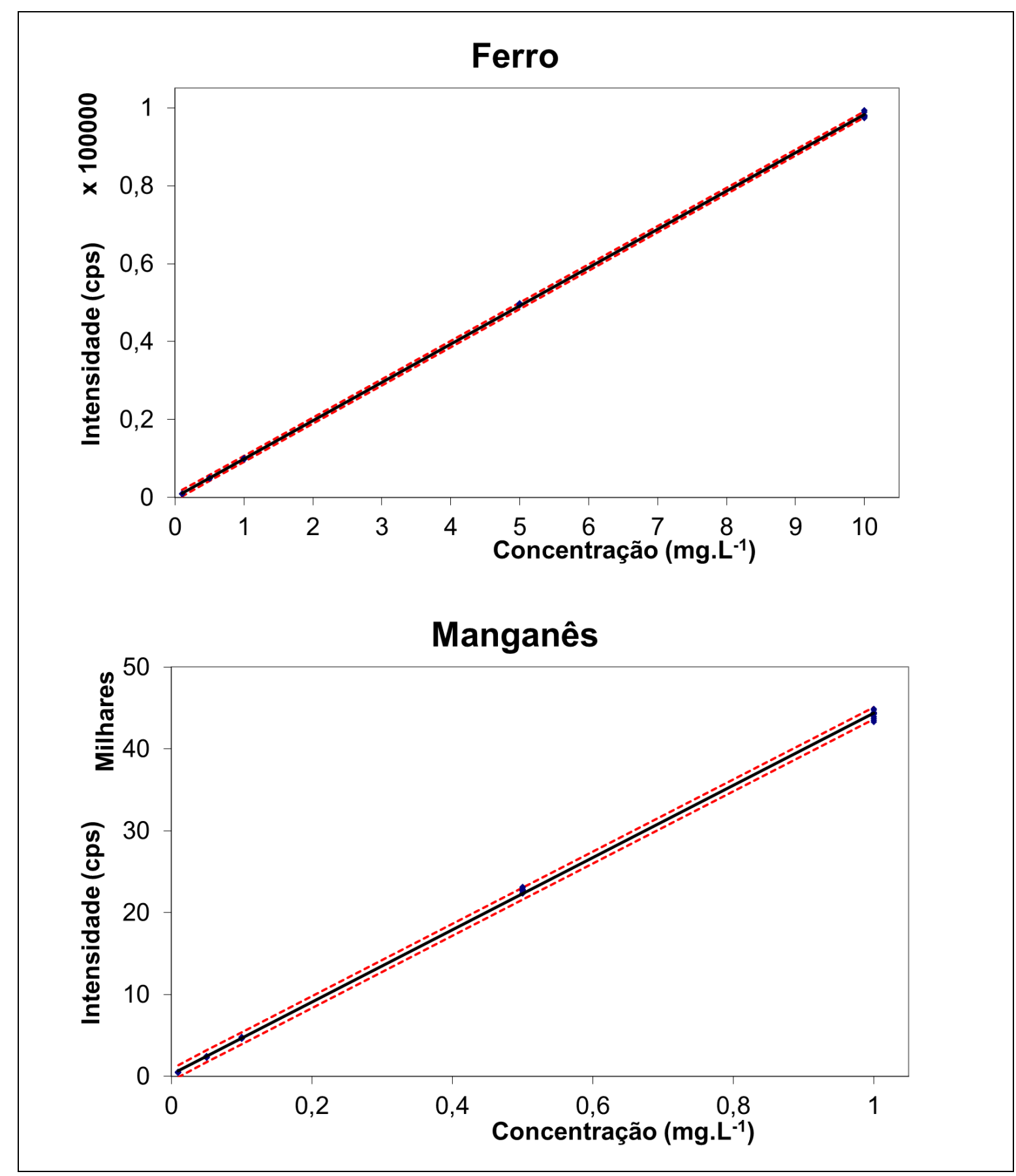

FIGURA 33: Resultados de intervalo de confiança de 95\% para as faixas de trabalho dos elementos Fe e Mn 


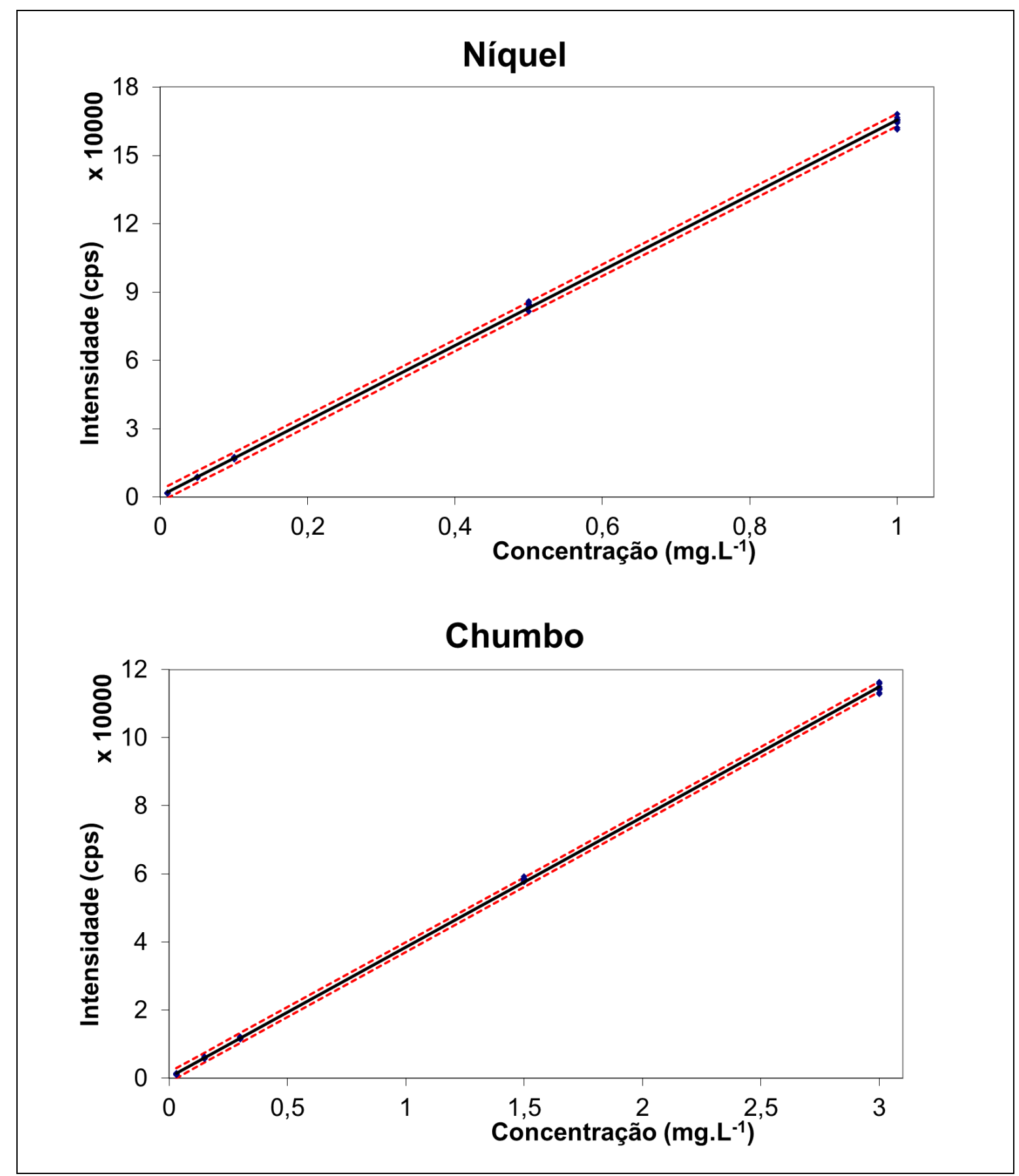

FIGURA 34: Resultados de intervalo de confiança de $95 \%$ para as faixas de trabalho dos elementos $\mathrm{Ni}$ e $\mathrm{Pb}$ 


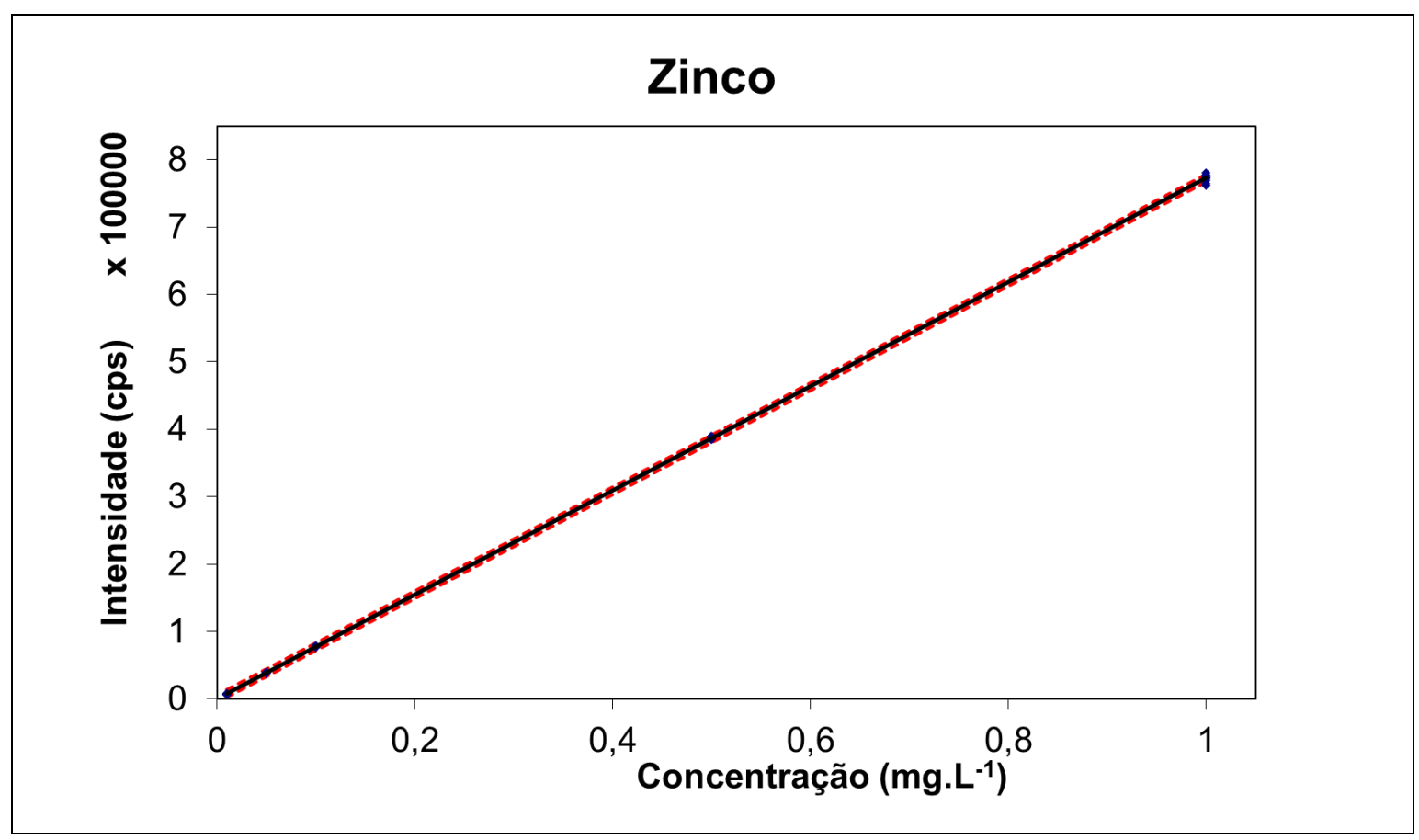

FIGURA 35: Resultados de intervalo de confiança de 95\% para as faixas de trabalho do elemento $\mathrm{Zn}$

\subsection{Limite de Detecção do Equipamento}

Os Limites de Detecção apresentados na TAB. 16 foram definidos nas condições de análise no período de validação. Estes valores podem variar e são sempre apresentados juntamente aos resultados de cada curva analítica construída.

TABELA 16: Resultados de LDE

\begin{tabular}{cc}
\hline Elemento & LDE $\left(\mathbf{m g} \cdot \mathbf{L}^{-1}\right)$ \\
B & 0,0021 \\
Sn & 0,0124 \\
Cd & 0,0009 \\
Ba & 0,0002 \\
Cr & 0,0067 \\
Cu & 0,0036 \\
\hline
\end{tabular}

\begin{tabular}{cc}
\hline Elemento & LDE $\left(\mathrm{mg} \cdot \mathrm{L}^{-1}\right)$ \\
$\mathrm{Fe}$ & 0,0078 \\
$\mathrm{Mn}$ & 0,0010 \\
$\mathrm{Ni}$ & 0,0024 \\
$\mathrm{~Pb}$ & 0,0078 \\
$\mathbf{Z n}$ & 0,0006 \\
\hline
\end{tabular}




\subsection{Limite de Detecção do Método}

Os resultados obtidos na determinação do limite de detecção do método estão apresentados na TAB. 17 e como pode-se observar na mesma tabela, estes resultados foram considerados satisfatórios para o objetivo do método analítico, por não suplantarem os valores definidos pela legislação ambiental vigente.

TABELA 17: Resultados de LDM

\begin{tabular}{|c|c|c|c|c|c|}
\hline Elemento & $\begin{array}{c}\text { LDM } \\
\left(\mathrm{mg}^{\left.-L^{-1}\right)}\right.\end{array}$ & $\begin{array}{c}\text { Legislação } \\
\text { (mg.L-1) }\end{array}$ & Elemento & $\begin{array}{c}\text { LDM } \\
\left(\mathrm{mg.L}^{-1}\right)\end{array}$ & $\begin{array}{c}\text { Legislação } \\
\text { (mg.L-1) }\end{array}$ \\
\hline B & 0,0066 & 5,0 & $\mathrm{Fe}$ & 0,0186 & 15,0 \\
\hline Sn & 0,0192 & 4,0 & Mn & 0,0011 & 1,0 \\
\hline Cd & 0,0009 & 0,2 & $\mathrm{Ni}$ & 0,0029 & 2,0 \\
\hline $\mathrm{Ba}$ & 0,0015 & 5,0 & $\mathrm{~Pb}$ & 0,0080 & 0,5 \\
\hline $\mathrm{Cr}$ & 0,0067 & 0,1 & $\mathrm{Zn}$ & 0,0027 & 5,0 \\
\hline $\mathrm{Cu}$ & 0,0037 & 1,0 & & & \\
\hline
\end{tabular}

Legislação = Valor máximo permitido definido pela legislação ambiental vigente.

\subsection{Limite de Quantificação do Método}

Na TAB. 18 é possível observar a concentração definida como limite de quantificação do método para todos os elementos estudados. Neste trabalho o LQM foi definido como primeiro ponto das curvas analíticas, uma vez que neste ponto foram obtidos resultados satisfatórios para a precisão na análise de todos os elementos, o que foi evidenciado pelos resultados de DPR\% obtidos, também apresentados na TAB. 18, para cada um dos valores de LQM. 
TABELA 18: Resultados de LQM e DPR

\begin{tabular}{ccccc}
\hline & $\mathrm{B}$ & $\mathrm{Sn}$ & $\mathrm{Cd}$ & $\mathrm{Ba}$ \\
\hline Conc. (mg. L-1) & 0,010 & 0,050 & 0,005 & 0,100 \\
DPR (\%) & 1,78 & 11,46 & 5,37 & 0,35 \\
\hline & $\mathrm{Cr}$ & $\mathrm{Cu}$ & $\mathrm{Fe}$ & $\mathrm{Mn}$ \\
\hline Conc. (mg.L-1) & 0,030 & 0,030 & 0,100 & 0,010 \\
DPR (\%) & 6,31 & 3,48 & 1,33 & 1,58 \\
\hline Conc. (mg.L-1) & $\mathrm{Ni}$ & $\mathrm{Pb}$ & $\mathrm{Zn}$ & \\
DPR (\%) & 0,010 & 0,030 & 0,010 & \\
\hline
\end{tabular}

Conc.: Concentração

Os limites de quantificação do método também foram considerados satisfatórios por serem inferiores aos limites definidos pela legislação ambiental vigente, o que permite que os resultados atendam à finalidade do método analítico.

\subsection{Precisão}

Seguem apresentados nos itens abaixo os resultados da precisão em termos de repetitividade, precisão intermediária e reprodutibilidade.

\subsubsection{Repetitividade}

Na FIG. 36 e FIG. 37 são apresentados os resultados da repetitividade da leitura das adições, nos anos de 2013 e 2014. Levando em consideração a baixa concentração dos analitos, determinou-se como aceitável DPR de até 16\% [123], portanto, os resultados foram considerados satisfatórios para todos os elementos. 


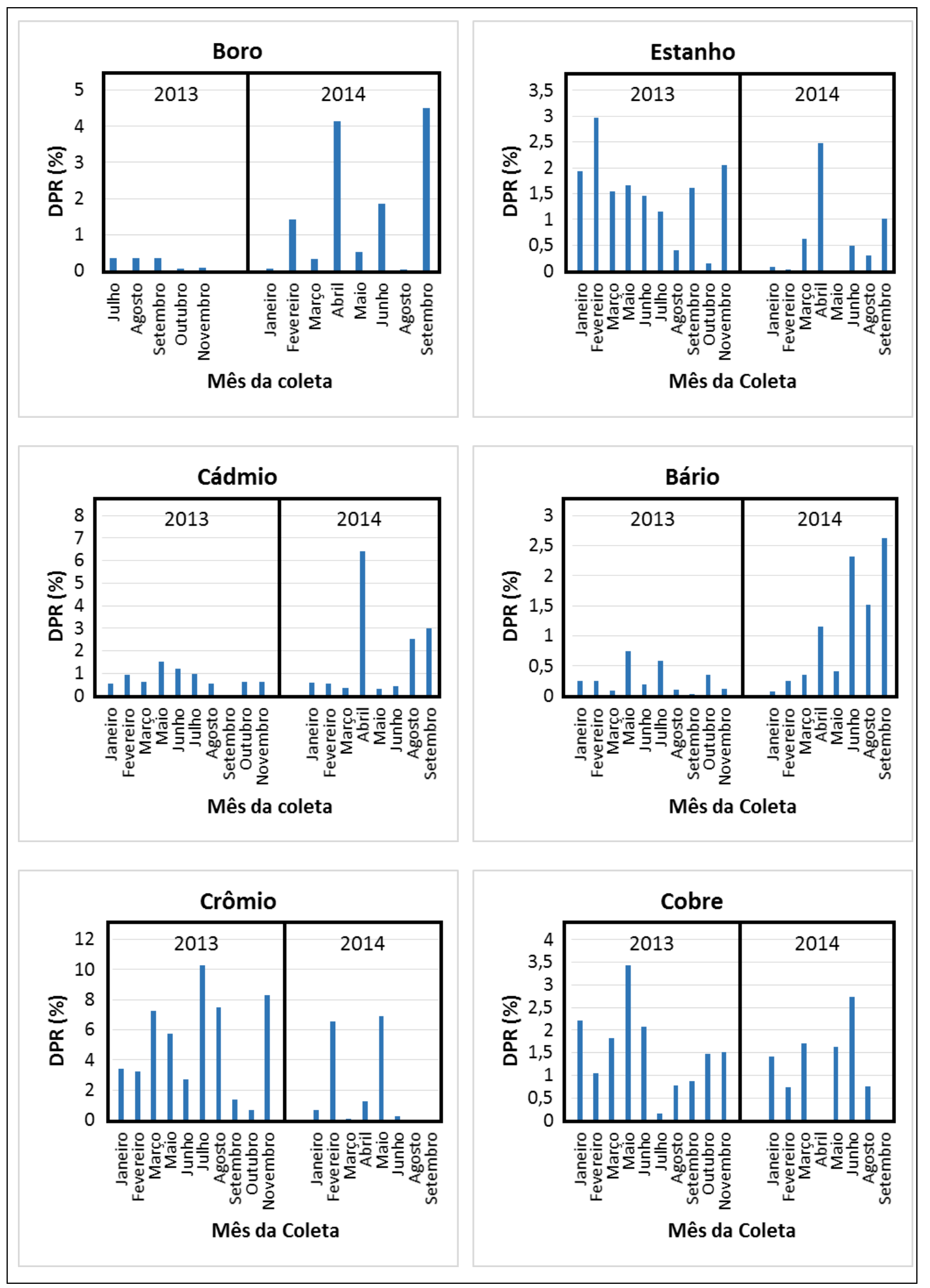

FIGURA 36: Resultados da repetitividade obtidos com a leitura das adições nos anos de 2013 e 2014, para os elementos B, Sn, Cd, Ba, Cr e Cu 


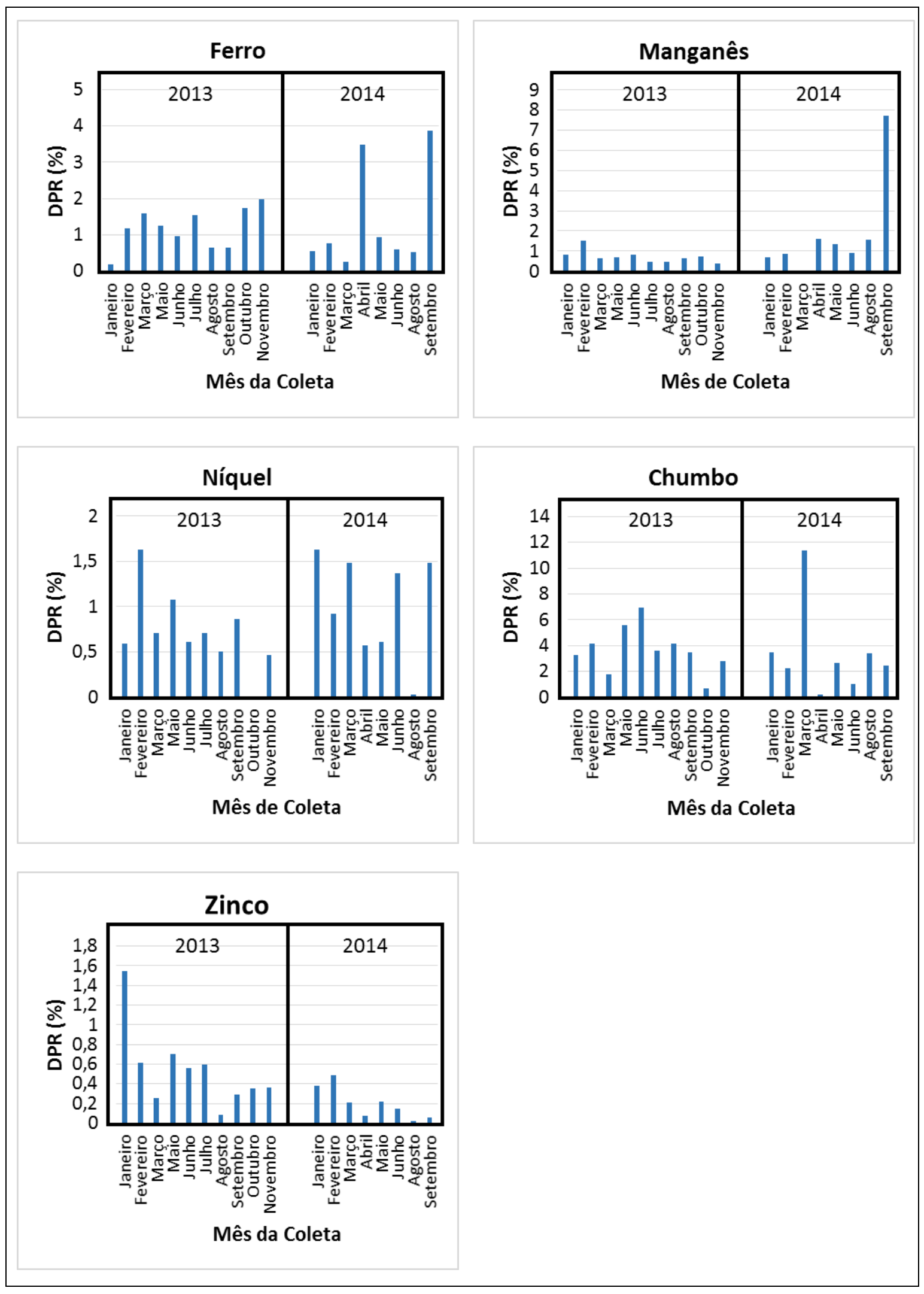

FIGURA 37: Resultados da repetitividade obtidos com a leitura das adições nos anos de 2013 e 2014, para os elementos Fe, Mn, Ni, Pb e Zn 


\subsubsection{Precisão Intermediária}

Na FIG. 38 é possível avaliar os resultados das duplicatas das amostras coletadas nos anos de 2013 e 2014. Na qual é possível verificar que os resultados, em sua grande maioria, encontram-se com variação aceitável, ou seja entre $80 \%$ e $120 \%$ de compatibilidade [119].

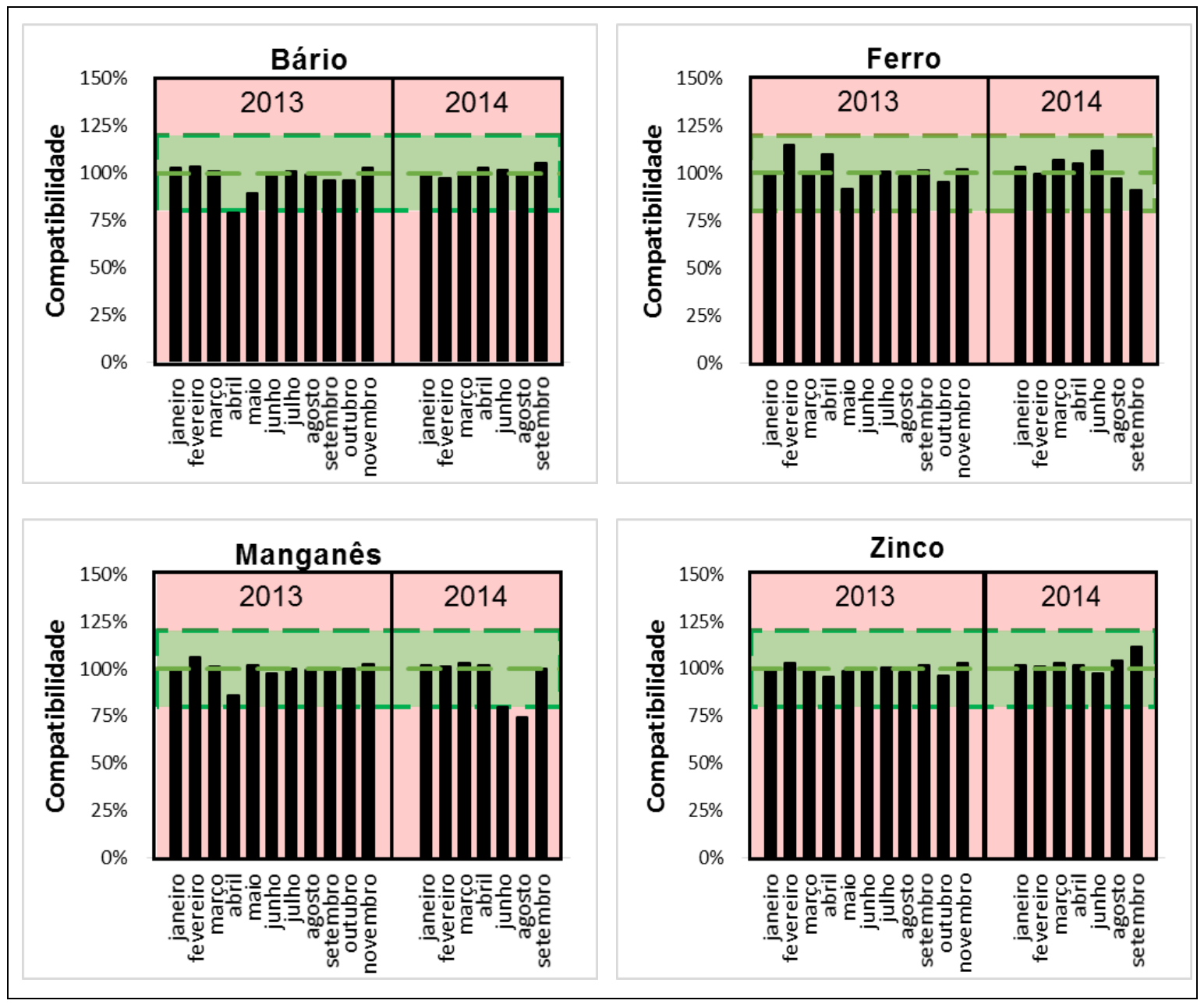

FIGURA 38: Resultados da precisão intermediária obtidos com a leitura das duplicatas independentes de 2013 e 2014

Os demais elementos apresentaram resultados menor que o LQM, tanto para a amostra quanto para a duplicata em todas as coletas de 2013 e 2014, assim impossibilitando uma avaliação mais cuidadosa e a representação gráfica dos resultados, no entanto os resultados também foram considerados satisfatórios por apresentarem compatibilidade. 


\subsubsection{Reprodutibilidade}

Verificando os resultados do interlaboratorial da Rede Metrológica do Rio Grande do Sul dos anos de 2013 e 2014, somente foi possível avaliar os resultados dos elementos zinco e cobre, uma vez que apenas estes elementos fizeram parte do programa nestas rodadas de efluente industrial. Os resultados obtidos tanto para zinco quanto para cobre foram 100\% satisfatórios, como apresentado na FIG. 39. Pode-se observar também que os resultados foram exatos e precisos, pois estão em concordância com o valor de consenso, além de apresentarem baixa dispersão.

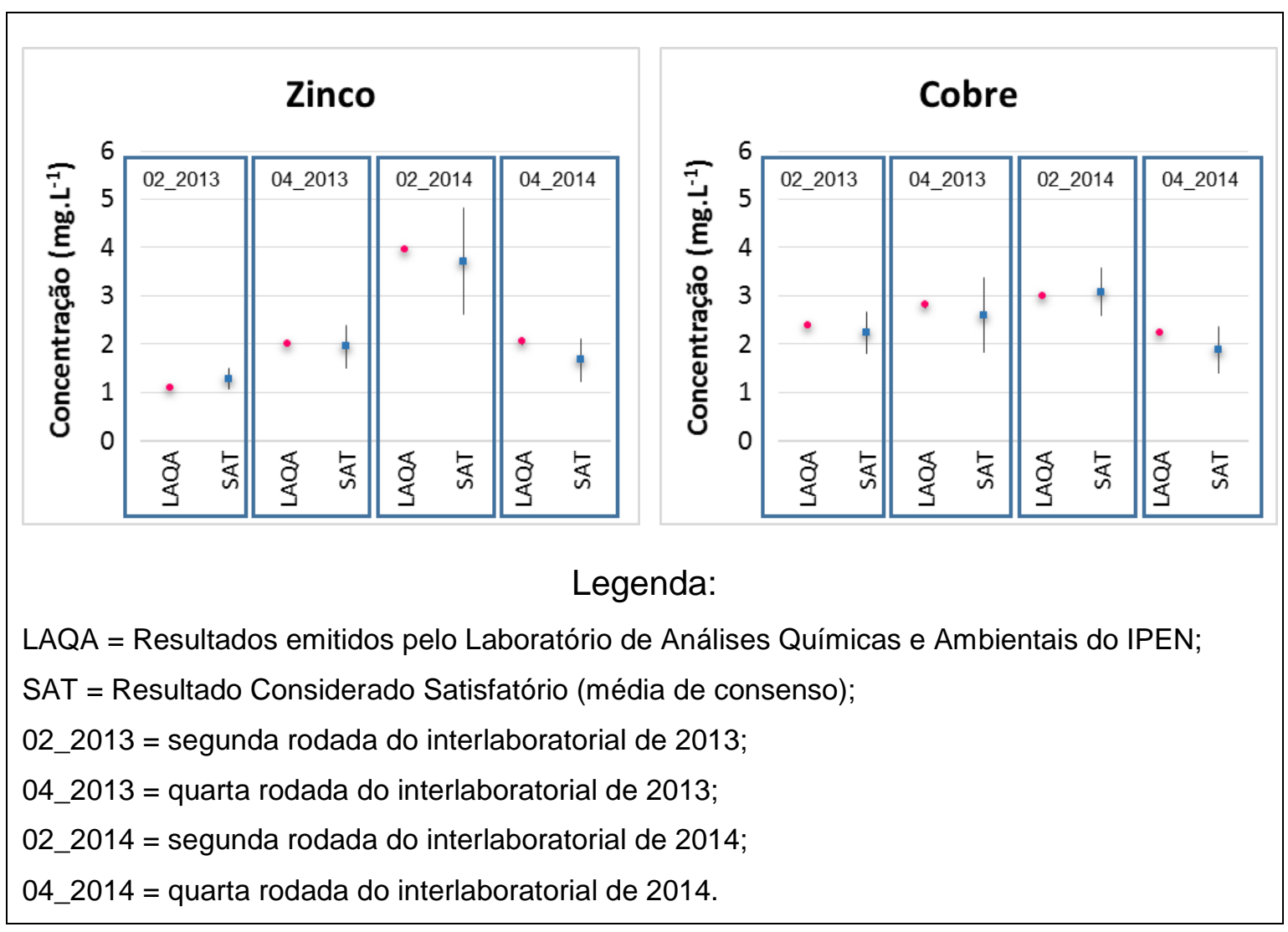

FIGURA 39: Resultados do programa interlaboratorial da Rede Metrológica do Rio Grande do Sul para Zn e Cu

\subsection{Recuperação}

Para avaliação dos resultados de recuperação foram utilizados os dados das amostras coletadas nos anos de 2013 e 2014. O grau de aceitação para a recuperação foi de $80 \%$ a $120 \%$ de recuperação [119]. 
Levando-se em consideração a faixa de aceitação já citada é possível observar, na FIG. 40 e FIG. 41, que os elementos B, Sn, Cd, Ba, Cu, Mn, Ni, Pb e $\mathrm{Zn}$ apresentaram a maioria dos resultados satisfatórios ao longo dos dois anos

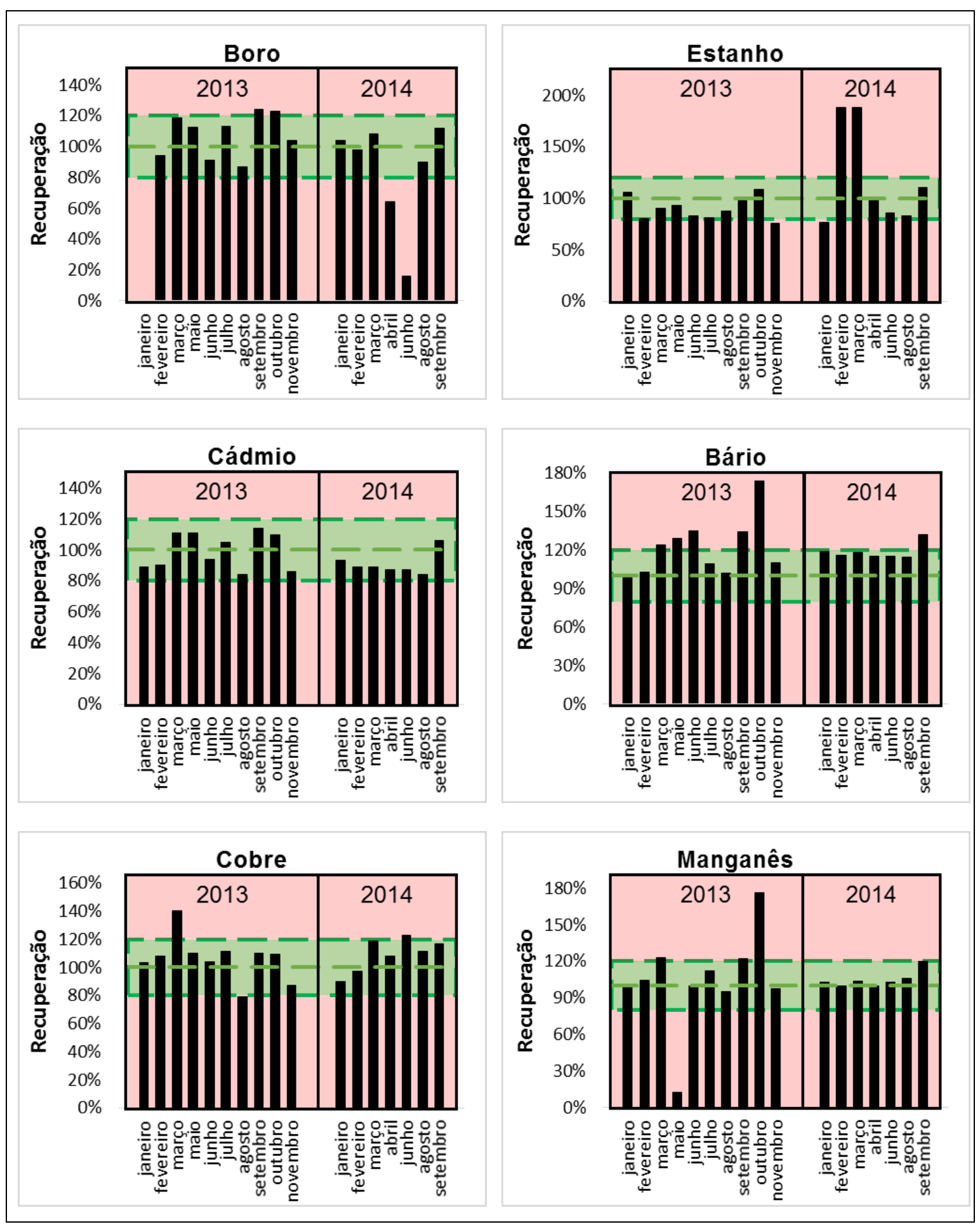

FIGURA 40: Resultados de recuperação obtidos com a leitura das adições em 2013 e 2014, para os elementos B, Sn, Cd, Ba, Cu e Mn 


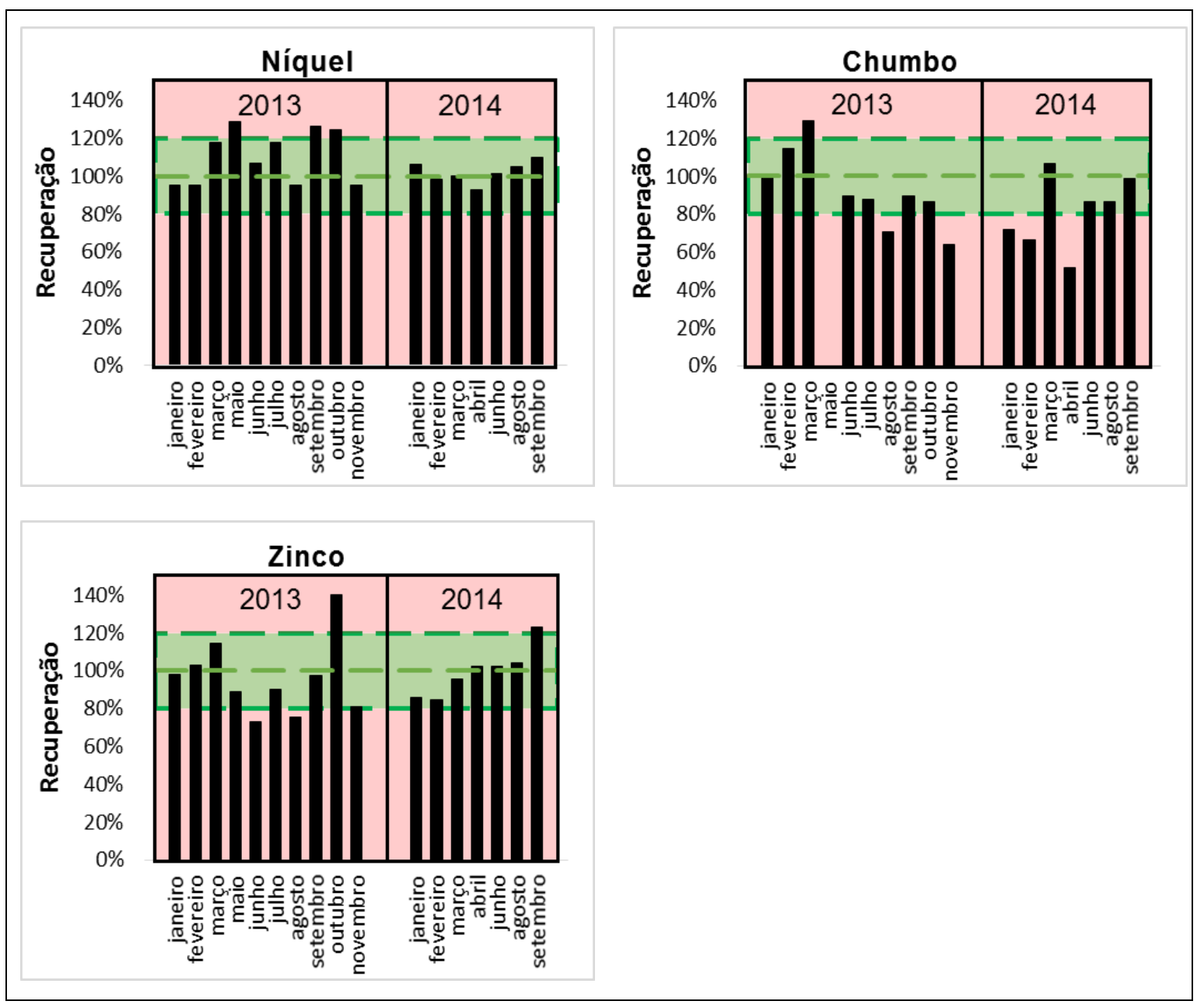

FIGURA 41: Resultados de recuperação obtidos com a leitura das adições em 2013 e 2014, para os elementos $\mathrm{Ni}$, Pb e Zn

Na FIG. 42 é possível observar os resultados de recuperação para os elementos $\mathrm{Cr}$ e $\mathrm{Fe}$, que foram os únicos elementos a apresentarem a maioria dos resultados insatisfatórios, ao longo do período avaliado. Porém, os resultados avaliados envolvem muito mais que concentrações alvo, variações do equipamento, variações de volume, diferentes operadores, variação no volume total da amostra e o processo de digestão devem ser levados em consideração, bem como possíveis contaminações do sistema. A adição é utilizada como um fator de controle de qualidade do método e ações são tomadas quando resultados insatisfatórios ocorrem. 


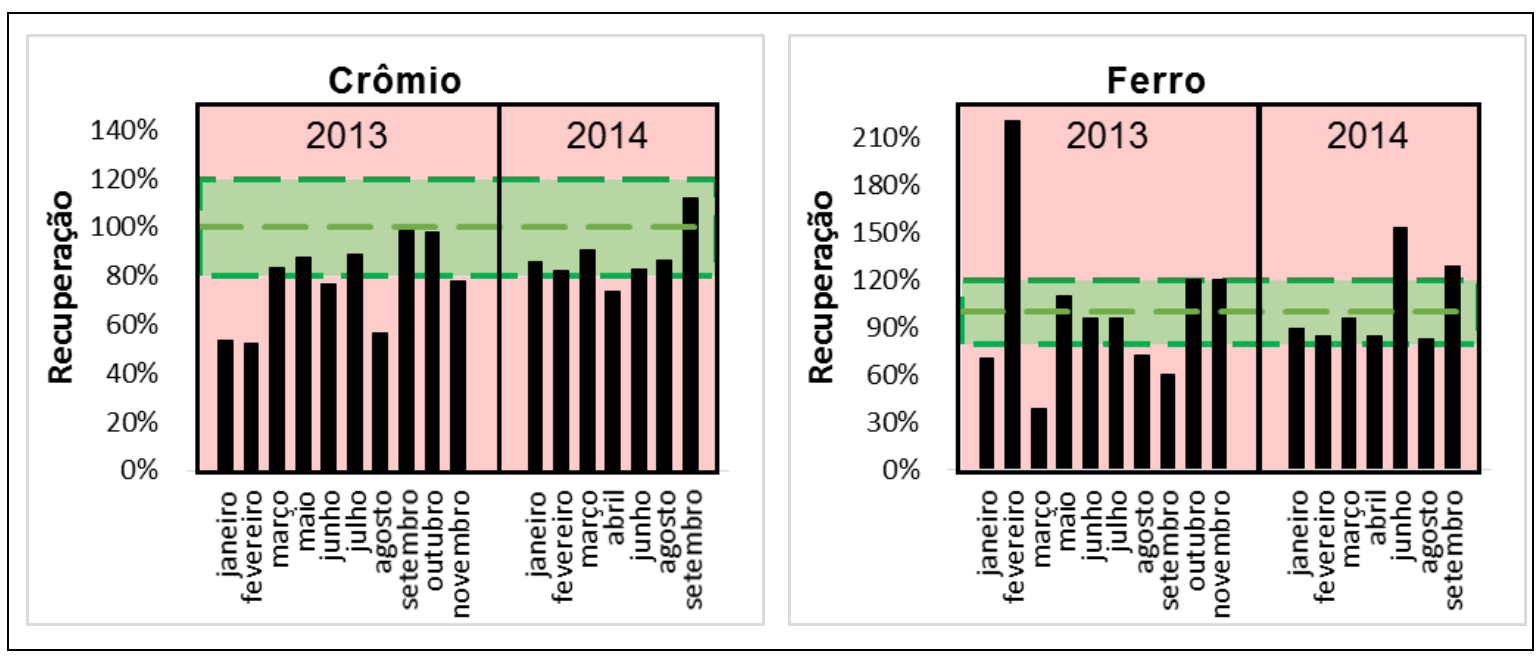

FIGURA 42: Resultados de recuperação obtidos com a leitura das adições em 2013 e 2014, para os elementos $\mathrm{Cr}$ e Fe

Todos os fatores citados foram melhor controlados no ano de 2014, e é possível verificar uma significativa melhora dos resultados de recuperação neste ano. Também deve ser levado em consideração que os resultados de recuperação impactam diretamente nos resultados de incerteza de medição, pois a recuperação é um fator contribuinte para a estimativa de incerteza (veja item 8.5.7), quanto melhor os resultados de recuperação, menor será a sua contribuição para a incerteza global do método analítico.

\subsection{Robustez}

Após a obtenção dos resultados das análises das 8 (oito) combinações ensaiadas, combinações na TAB. 8 apresentada no item 8.4.9 (página 111 desta dissertação), os dados foram tratados e na FIG. 43 e FIG. 44 estão apresentados os gráficos para avaliação da influência de cada um dos parâmetros testados.

É possível observar que $91 \%, 82 \%, 55 \%, 64 \%$ e $45 \%$ dos elementos apresentaram efeito positivo para variações na qualidade da água, velocidade da bomba, pressão do nebulizador, temperatura do laboratório e volume de $\mathrm{HNO}_{3}$, respectivamente. No caso de efeito positivo sugere-se que valores nominais para os parâmetros estudados favorecem na determinação do analito, e no caso de efeito negativo há um favorecimento na determinação do analito em relação à alteração do parâmetro [124]. 
No caso dos parâmetros potência do plasma e volume de $\mathrm{HCl}$ foi observado $100 \%$ de resultados negativos na avaliação do parâmetro, ou seja, a variação estudada favorece a determinação do analito. Porém, a potência do plasma é um parâmetro do equipamento e é importante que seja mantido estável tanto no momento da calibração quanto no momento das análises. Esta variação já era esperada uma vez que o aumento da potência do plasma também causa o aumento da população de analito excitado, resultando diretamente em um aumento da sensibilidade do equipamento.

No caso do volume de $\mathrm{HCl}$, de acordo com o método de digestão ácida EPA 3015A [115], a adição de $\mathrm{HCl}$ é importante para a estabilidade de alguns elementos, como o estanho, ao longo do período de preservação das amostras, desta forma não são necessárias alterações do método de análise.

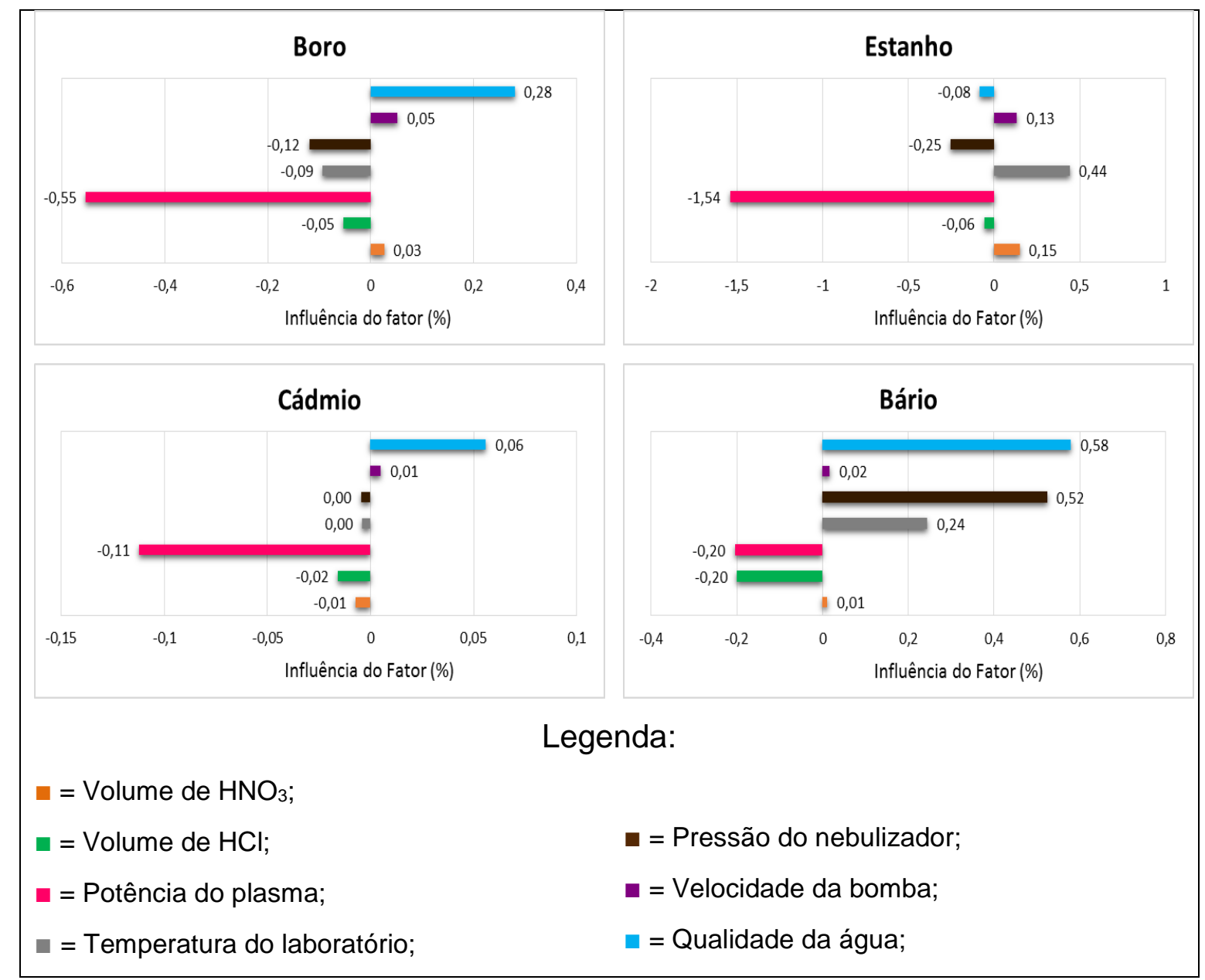

FIGURA 43: Efeito dos parâmetros escolhidos para a avaliação da robustez do método de quantificação de $\mathrm{B}, \mathrm{Sn}, \mathrm{Cd}$ e $\mathrm{Ba}$ 


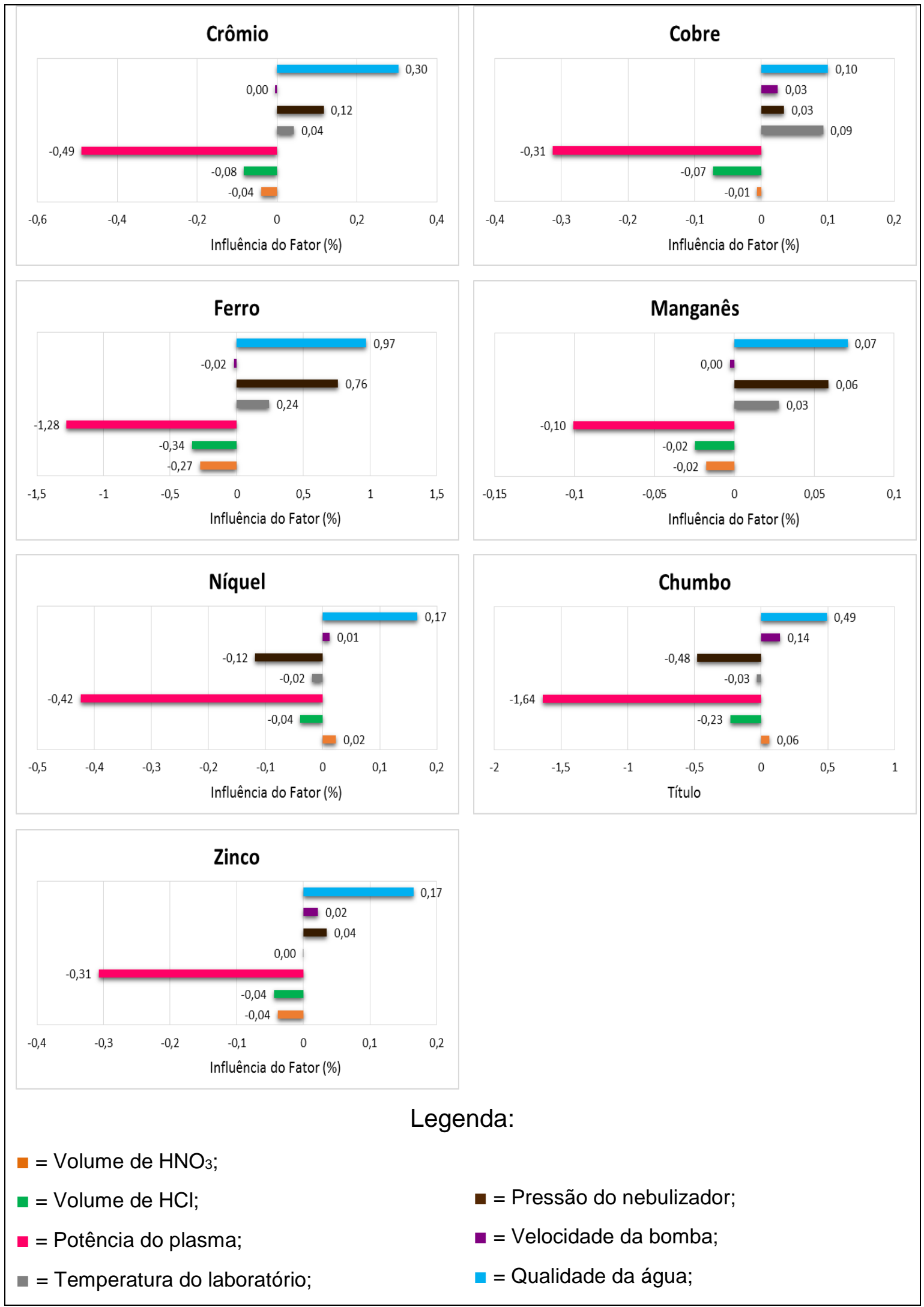

FIGURA 44: Efeito dos parâmetros escolhidos para a avaliação da robustez do método de quantificação de $\mathrm{Cr}, \mathrm{Cu}, \mathrm{Fe}, \mathrm{Mn}, \mathrm{Ni}, \mathrm{Pb}$ e $\mathrm{Zn}$ 
Para o estudo da robustez também foram avaliados os gráficos de Rankit apresentados na FIG. 45 e na FIG. 46. É possível verificar que o parâmetro potência do plasma apresentou variação significativa para os elementos boro, estanho, cádmio, cobre, níquel, chumbo e zinco. E para os elementos cádmio e zinco outro parâmetro que apresentou variações significativas foi a qualidade da água utilizada no preparo dos padrões. Em todos os casos citados os resultados superaram o limite de SME o que demonstra que estes parâmetros devem ser controlados, pois variações durante a realização das análises podem impactar em falta de precisão e exatidão dos resultados.

O parâmetro qualidade da água também apresentou impacto no resultado do elemento níquel, e o parâmetro potência do plasma apresentou impacto no resultado do elemento crômio, mas estes resultados apenas superaram o limite de $\mathrm{ME}$, o que demonstra que não ocorrem implicações significativas para variações nestes quesitos, porém é aconselhável maior controle destes parâmetros para que não haja grandes variações nos resultados das análises.

No laboratório de análises do CQMA, como já foi citado anteriormente, a potência do plasma é um parâmetro controlado pelo analista para evitar a ocorrência de variações durante a realização das análises e também é de praxe a utilização de água ultrapura para o preparo dos padrões e diluição de amostras, o que proporciona maior estabilidade e exatidão dos resultados.

Na FIG. 45 e FIG. 46 também é possível observar que os demais parâmetros não apresentaram efeito significativo para nenhum dos elementos analisados. 


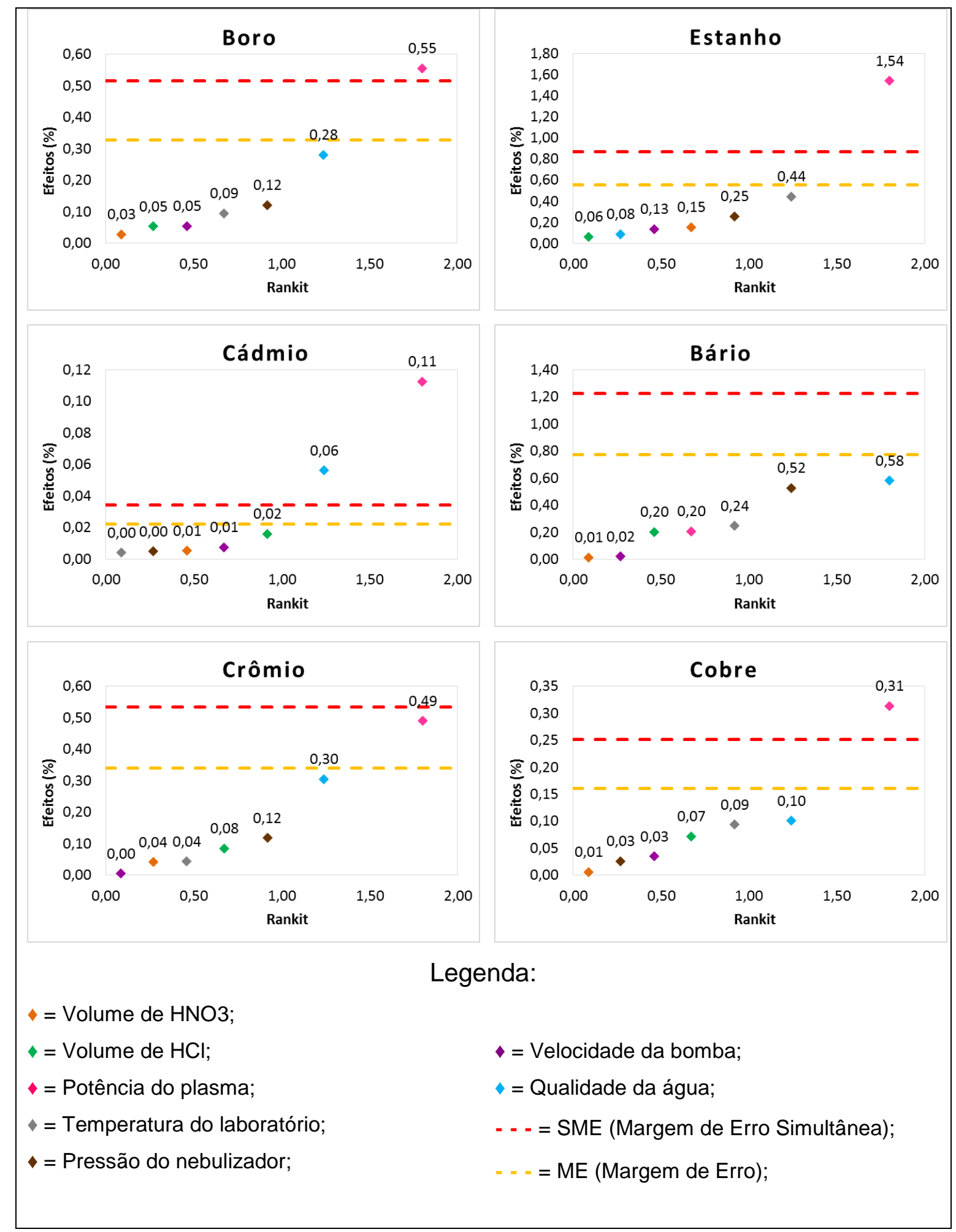

FIGURA 45: Gráficos Rankit para B, Sn, Cd, Ba Cr e Cu 


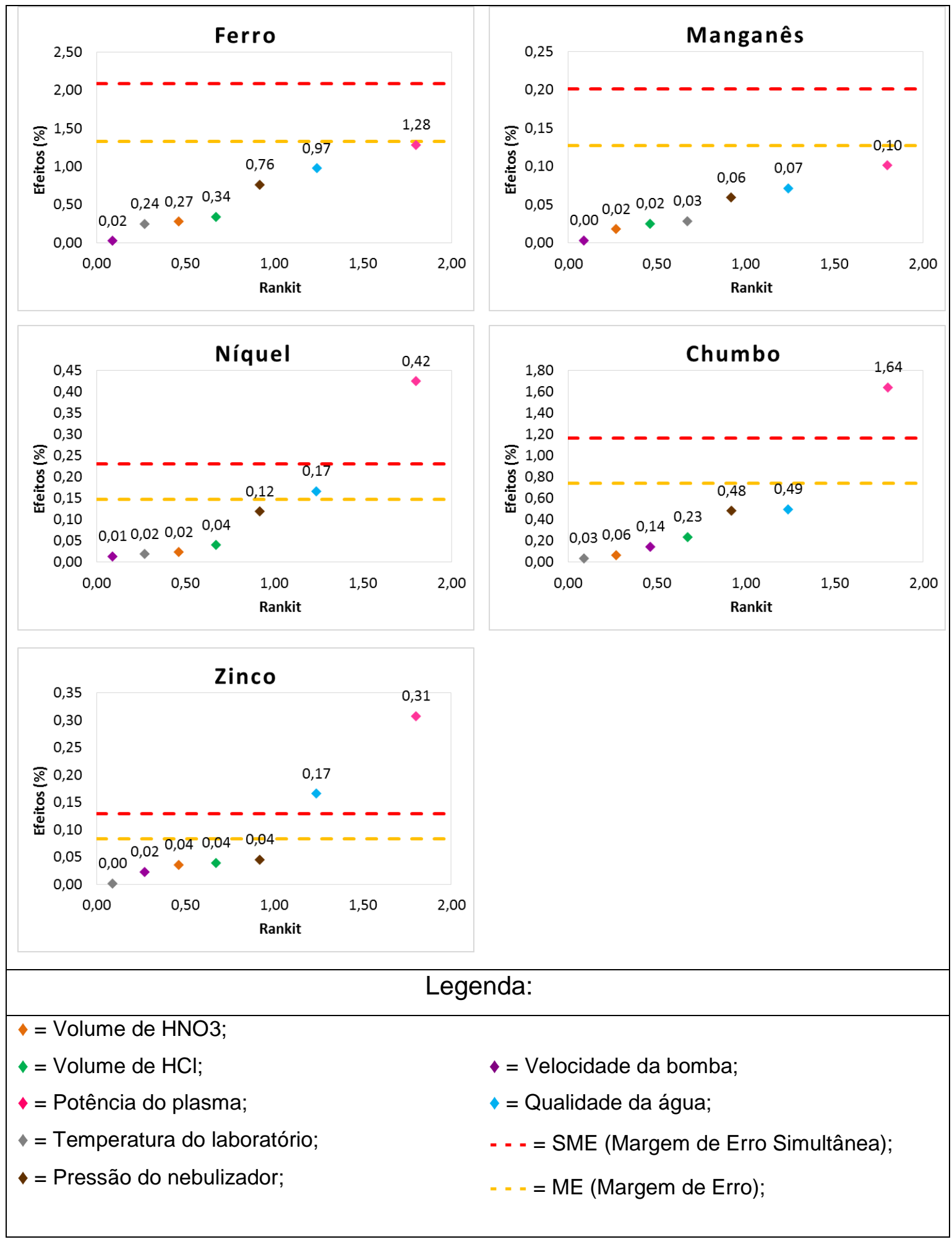

FIGURA 46: Gráficos Rankit para Fe, Mn, Ni, Pb e Zn

Em complemento aos resultados apresentados, foram elaborados os gráficos de probabilidade normal, apresentados na FIG. 47 e FIG. 48, onde é possível observar que os dados apresentam comportamento linear e estão 
distribuídos no intervalo que caracteriza \pm 2 desvios padrão, indicando a ausência de dados discrepantes e/ou espúrios.

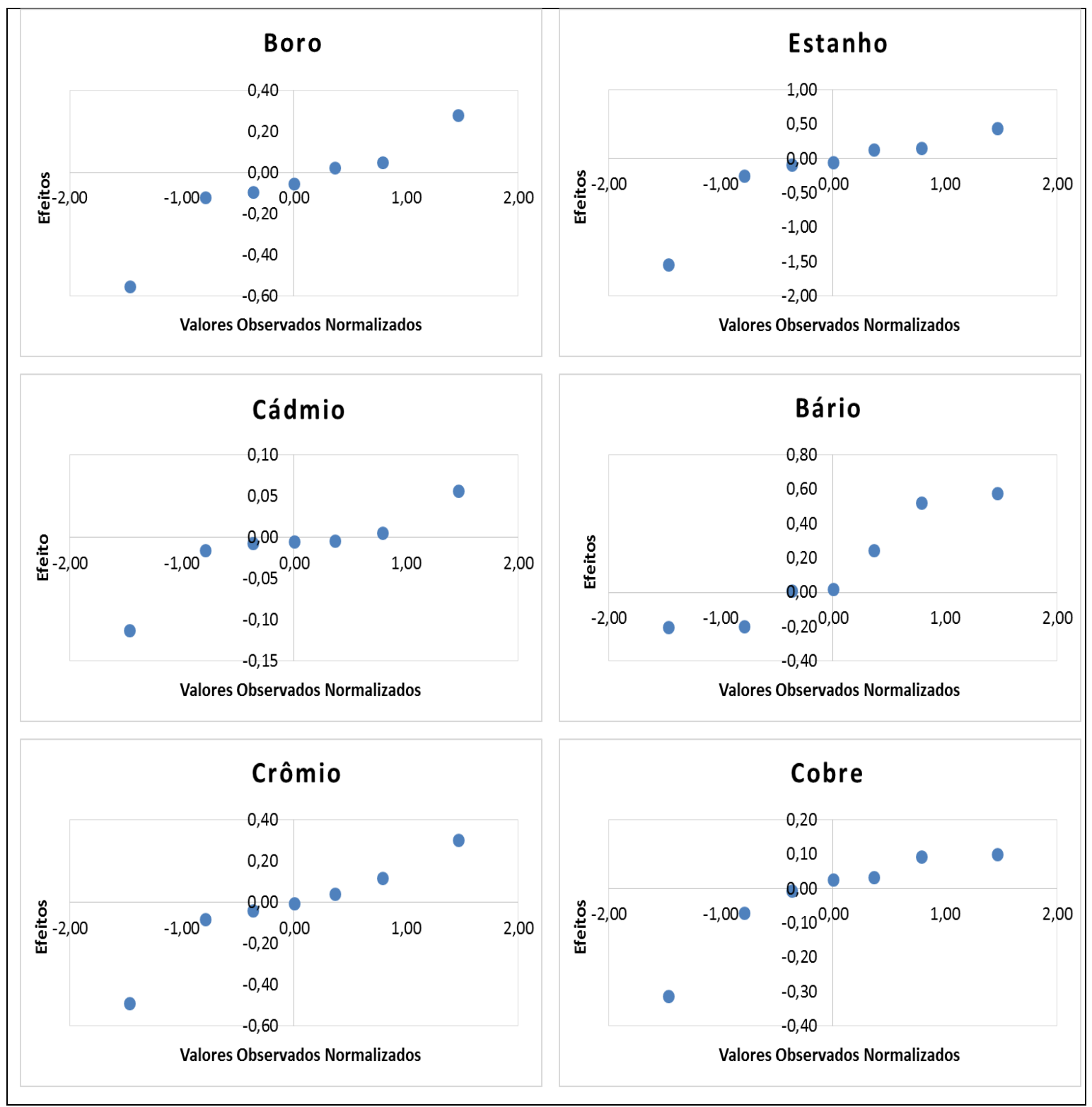

FIGURA 47: Gráficos de probabilidade normal para B, Sn, Cd, Ba, Cr e Cu 


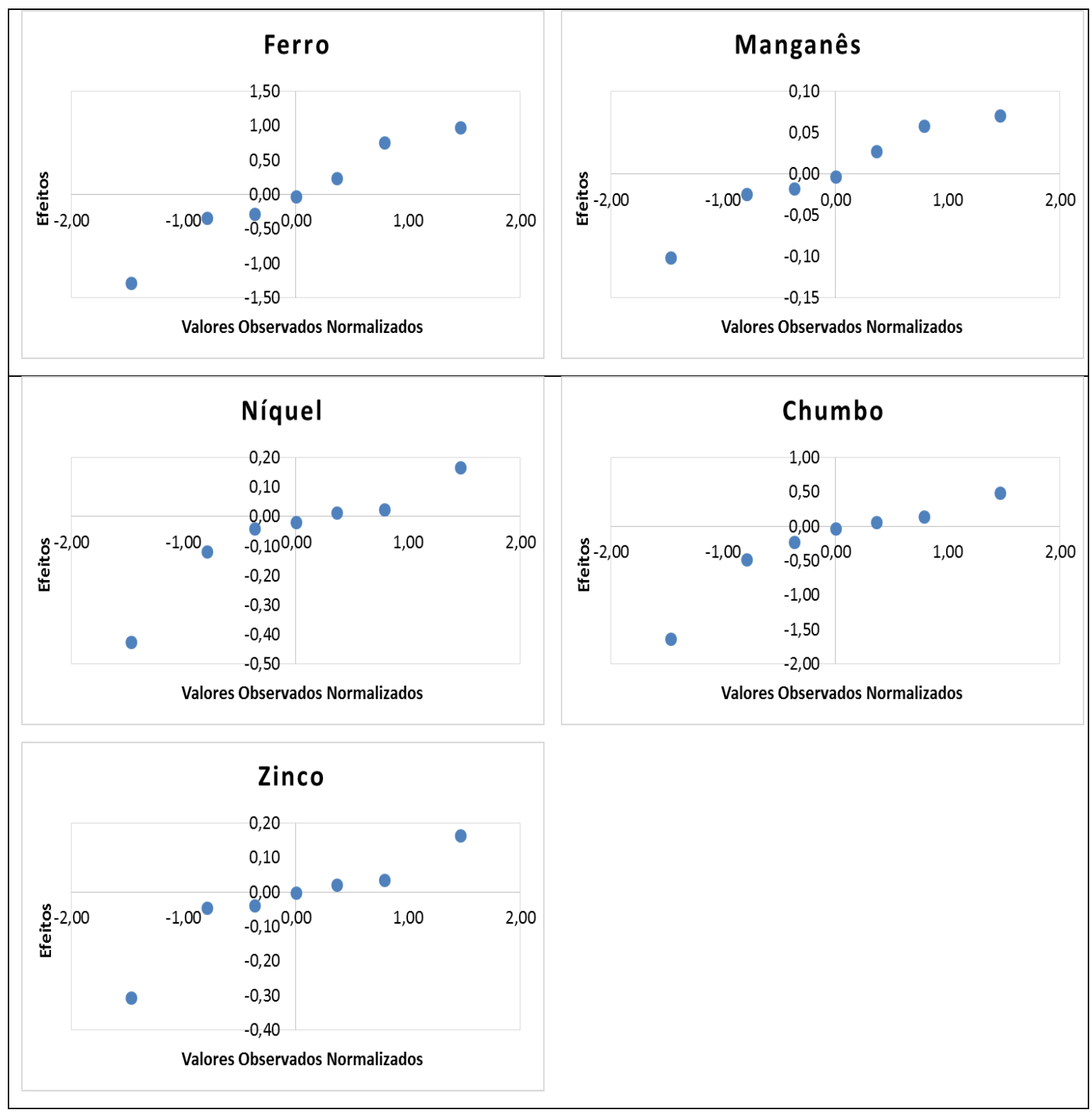

FIGURA 48: Gráficos de probabilidade normal para $\mathrm{Fe}, \mathrm{Mn}, \mathrm{Ni}, \mathrm{Pb}$ e Zn

O teste de robustez também pode ser utilizado para otimização do método analítico antes do processo de validação do mesmo. No entanto, neste trabalho este teste somente foi utilizado para avaliação de influências no método analítico em casos de transporte e/ou implantação do método analítico em outros laboratórios, uma vez que o objetivo do presente trabalho é validar a metodologia já aplicada nos laboratórios do CQMA e manter o histórico de dados do PMA-Q. Somente foram realizadas modificações (otimizações) imprescindíveis para a obtenção de resultados adequados aos objetivos do método analítico. 


\subsection{Estimativa de Incerteza de Medição}

Após o levantamento das fontes de incerteza, combinação e expansão destas fontes, foi possível estimar a incerteza global de medição para todos os analitos do método estudado. A incerteza expandida foi estimada próximo ao ponto médio da curva analítica de cada um dos elementos. Os resultados de incerteza padrão relativa $(\mu(x) / x)$, a concentração utilizada como base de cálculo, a incerteza combinada e incerteza expandida podem ser observados na TAB. 19.

A contribuição de cada uma das fontes de incerteza pode ser avaliada observando a FIG. 49 e FIG. 50. É possível observar que a fonte de incerteza que mais contribui para a incerteza expandida de todos os elementos estudados é a incerteza da recuperação do método, o que é esperado por serem utilizados os resultados das adições realizadas para as digestões das amostras coletadas em 2013 e 2014, o que implica em maior desvio padrão dos resultados impactando diretamente nos resultados de incerteza de medição. Porém a utilização destes dados também implica em um resultado de incerteza de medição mais conservador e mais abrangente.

Também é possível observar que a incerteza de medição calculada para o fator volume apresentou-se insignificante frente às demais contribuintes para a incerteza global, para todos os elementos. Desta forma, em caso de otimização do método analítico, afim de reduzir a incerteza de medição, o analista deve focar nos fatores que influenciam a recuperação do método analítico para a obtenção de resultados significativos. 
TABELA 19: Contribuição das fontes de incerteza, concentração, incerteza combinada e incerteza expandida dos analitos

\begin{tabular}{|c|c|c|c|c|c|c|c|c|c|}
\hline & \multicolumn{4}{|c|}{$\mu(\mathbf{x}) / \mathbf{x}$} & \multirow[b]{2}{*}{$\operatorname{Rec}$} & \multirow[b]{2}{*}{$\mathrm{C}_{0}\left(\mathrm{mg} \cdot \mathrm{L}^{-1}\right)$} & \multirow[b]{2}{*}{$\mu$ comb. $\left(\mathrm{mg} \cdot \mathrm{L}^{-1}\right)$} & \multicolumn{2}{|c|}{ Incerteza Expandida } \\
\hline & V & Prep. & $\mathrm{C}_{0}$ & Rep & & & & $U\left(m g \cdot L^{-1}\right)$ & U (\%) \\
\hline B & 0,00122 & 0,00792 & 0,01200 & 0,00463 & 0,03014 & 0,2499 & 0,00843071 & 0,01686142 & 6,75 \\
\hline Sn & 0,00122 & 0,00847 & 0,01116 & 0,00701 & 0,03181 & 1,5230 & 0,05403733 & 0,10807465 & 7,10 \\
\hline Cd & 0,00122 & 0,00803 & 0,00792 & 0,00726 & 0,02756 & 0,1260 & 0,00387114 & 0,00774227 & 6,13 \\
\hline $\mathrm{Ba}$ & 0,00122 & 0,00893 & 0,00875 & 0,00378 & 0,01888 & 2,9710 & 0,06829902 & 0,13659805 & 4,60 \\
\hline $\mathrm{Cr}$ & 0,00122 & 0,00851 & 0,01603 & 0,01844 & 0,02713 & 0,8110 & 0,03041985 & 0,06083970 & 7,50 \\
\hline $\mathrm{Cu}$ & 0,00122 & 0,00807 & 0,00869 & 0,00705 & 0,02975 & 0,9210 & 0,03022481 & 0,06044963 & 6,56 \\
\hline Fe & 0,00122 & 0,00841 & 0,00621 & 0,00492 & 0,06001 & 3,0610 & 0,18710633 & 0,37421267 & 12,23 \\
\hline Mn & 0,00122 & 0,00794 & 0,01101 & 0,00391 & 0,02226 & 0,2725 & 0,00719230 & 0,01438460 & 5,28 \\
\hline $\mathrm{Ni}$ & 0,00122 & 0,00892 & 0,00391 & 0,00385 & 0,02605 & 0,2555 & 0,00718123 & 0,01436245 & 5,62 \\
\hline $\mathbf{P b}$ & 0,00122 & 0,00807 & 0,01425 & 0,01077 & 0,04630 & 0,7720 & 0,03882221 & 0,07764443 & 10,06 \\
\hline Zn & 0,00122 & 0,00839 & 0,00617 & 0,00170 & 0,03210 & 0,3243 & 0,01096597 & 0,02193194 & 6,76 \\
\hline
\end{tabular}




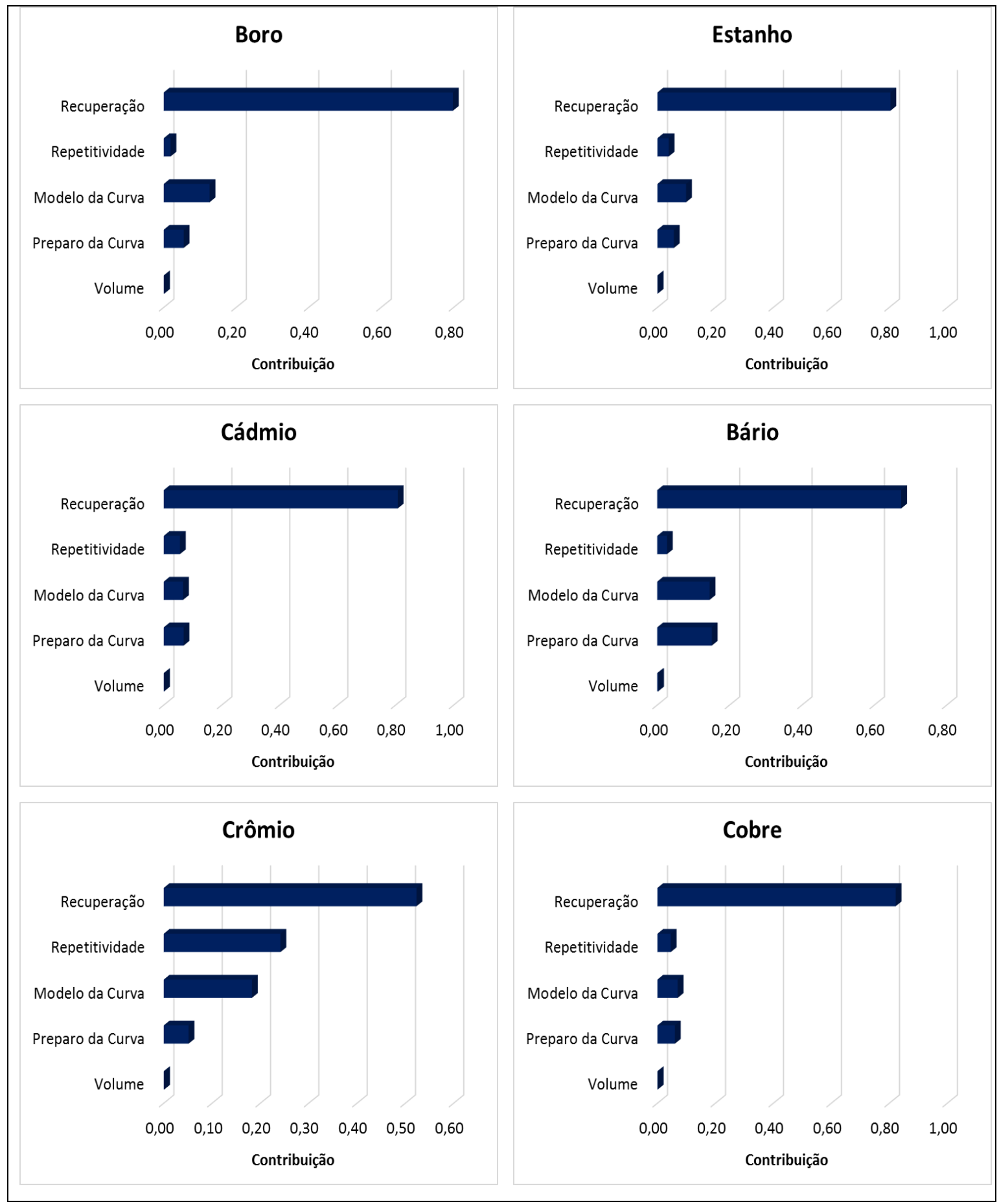

FIGURA 49: Contribuição das incertezas combinadas envolvidas na determinação de B, Sn, Cd, Ba, Cr e Cu 


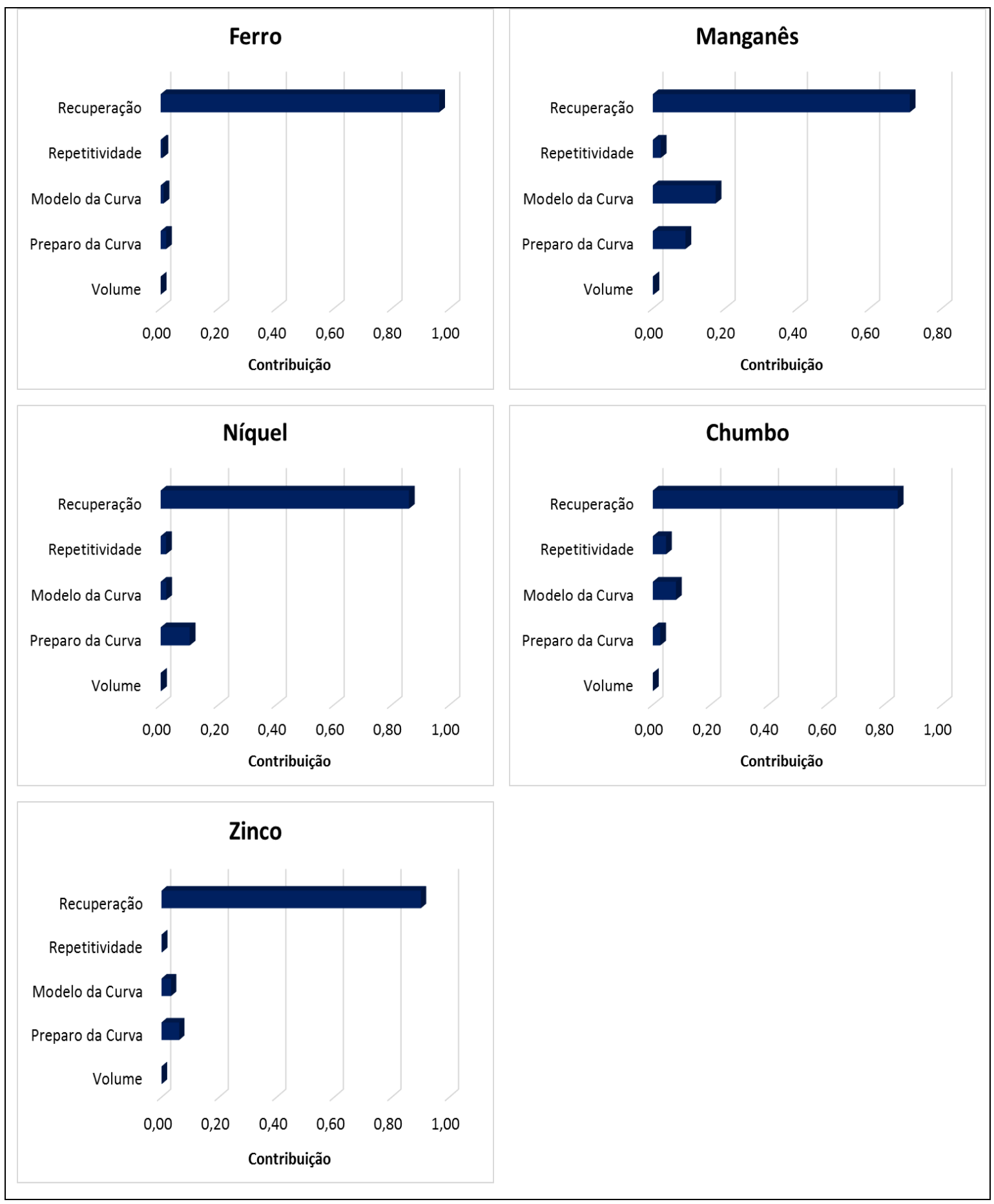

FIGURA 50: Contribuição das incertezas combinadas envolvidas na determinação de $\mathrm{Fe}, \mathrm{Mn}, \mathrm{Ni}, \mathrm{Pb}$ e $\mathrm{Zn}$

\subsection{Aplicação da Metodologia Analítica Estudada}

Desde 2006 a metodologia analítica estudada é utilizada para a determinação de metais e semimetais presentes no efluente do instituto que é lançado na rede coletora de esgoto. Após o estudo e validação da metodologia analítica e a estimativa da incerteza dos resultados obtidos com esta metodologia 
é possível realizar uma melhor avaliação dos resultados de concentração dos metais no efluente. Além de prover o IPEN de mais informações sobre os resultados, de modo que seja possível verificar se realmente o efluente lançado em rede coletora de esgoto atende os requisitos determinados pela legislação ambiental vigente.

Na FIG. 51 é possível observar os resultados da concentração de zinco, com a estimativa de incerteza e o limite definido pela legislação ambiental (Resolução CONAMA 430, DE 8.468 e DE15425/76). 


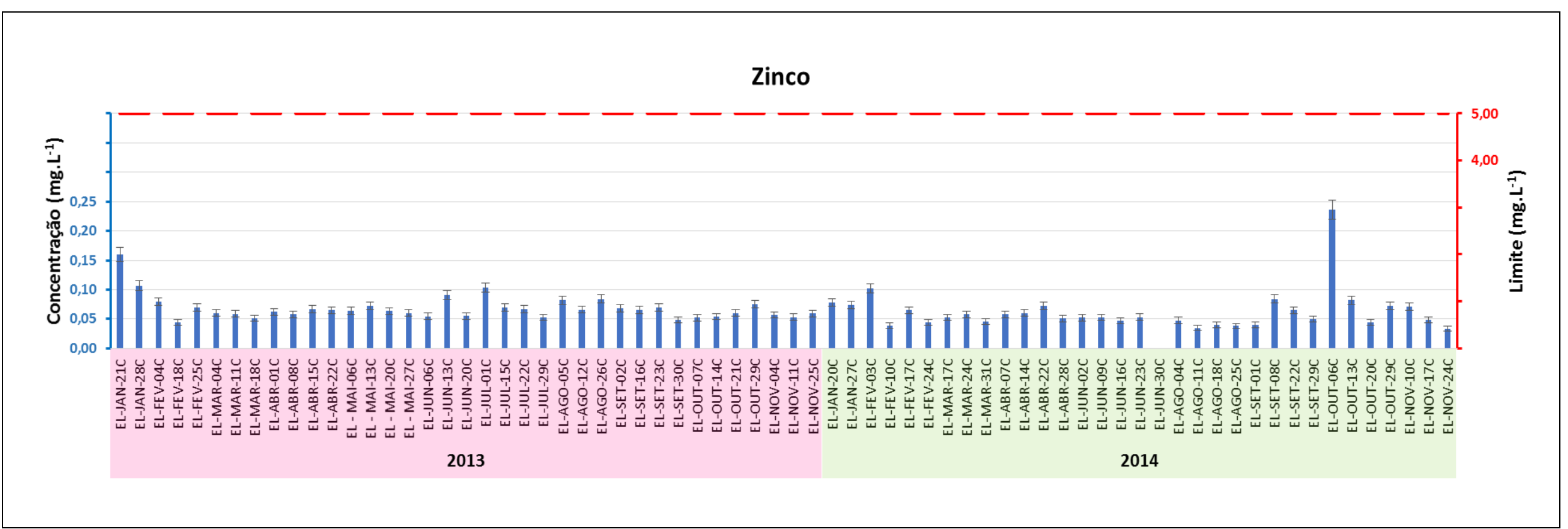

FIGURA 51: Resultados da concentração de zinco em amostras de efluente coletadas em 2013 e 2014, com a incerteza de medição e limite da legislação

Na figura acima é possível observar que ainda com a dispersão dos resultados (barra de incerteza de medição), mesmo o valor máximo de concentração de zinco (amostra EL-OUT-06C com aproximadamente 0,25 mg. $\mathrm{L}^{-1}$ ) não atinge o limite estipulado pela legislação ambiental (5 mg.L-1 ), durante o período de coleta avaliado (de janeiro de 2013 a novembro de 2014 ).

Na FIG. 52 é possível observar os resultados da concentração de zinco, com a estimativa de incerteza e limite da legislação ambiental (Resolução CONAMA 430, DE 8.468 e DE15425/76). 


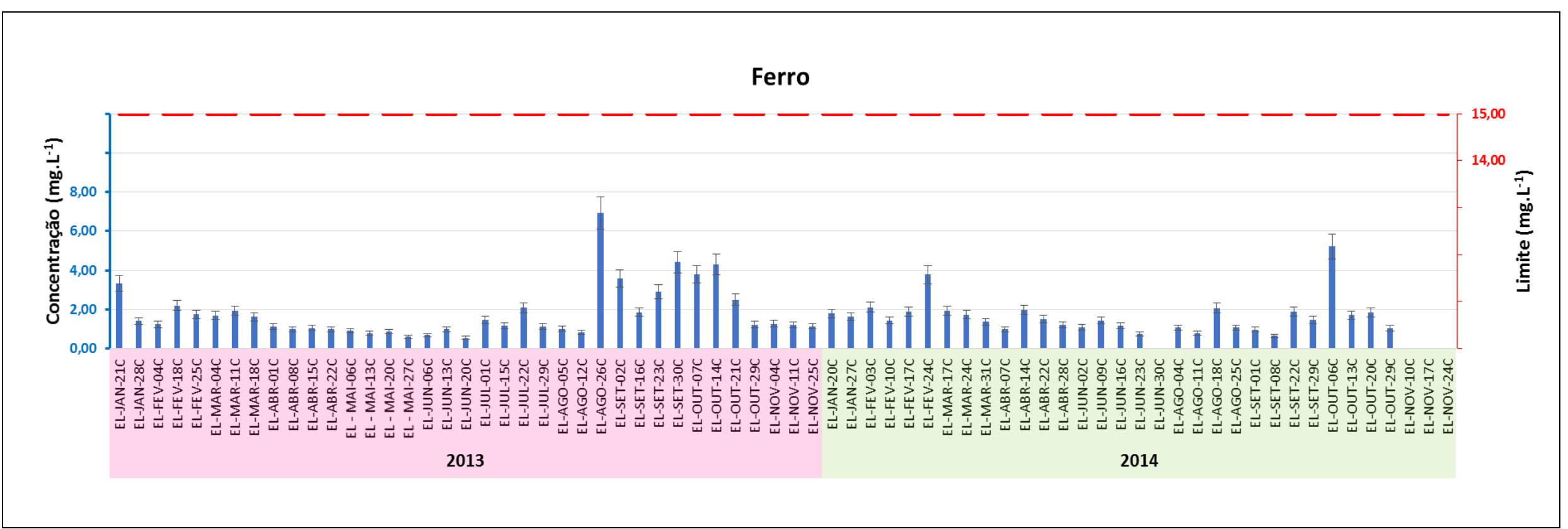

FIGURA 52: Resultados da concentração de ferro em amostras de efluente coletadas em 2013 e 2014, com a incerteza de medição e limite da legislação

E também é possível observar que o ferro é o elemento presente em maior concentração no efluente do instituto, dentre os metais e semimetais estudados. A maior concentração observada, no período de coletas de janeiro de 2013 a novembro de 2014, foi na amostra EL-AGO-26C, com resultado de aproximadamente $8 \mathrm{mg} \cdot \mathrm{L}^{-1}$, mesmo este resultado não atinge o limite estipulado pela legislação ambiental, que é de $15 \mathrm{mg} \cdot \mathrm{L}^{-1}$.

Na FIG. 53 é possível observar os resultados da concentração de manganês, com a estimativa de incerteza e limite da legislação ambiental (Resolução CONAMA 430, DE 8.468 e DE15425/76). 


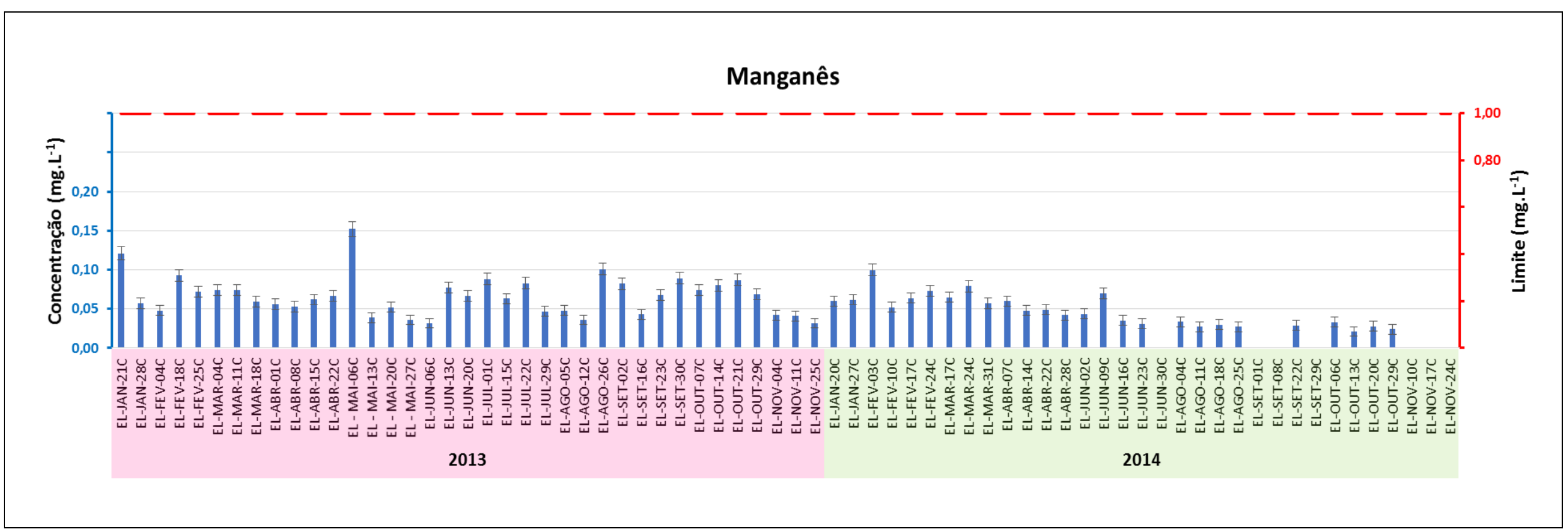

FIGURA 53: Resultados da concentração de manganês em amostras de efluente coletadas em 2013 e 2014, com a incerteza de medição e limite da legislação

Bem como os resultados apresentados anteriormente, é possível verificar que os resultados de manganês também não apresentam valores acima do valor definido pela legislação ambiental (1 mg. $\left.\mathrm{L}^{-1}\right)$, mesmo para o maior valor encontrado no período de coletas de janeiro de 2013 a novembro de 2014 (0,15 mg.L-1). Também é possível observar uma tendência na diminuição da concentração deste elemento no efluente. 
Não foi possível realizar a avaliação gráfica dos resultados dos demais metais e semimetais estudados ( $\mathrm{B}, \mathrm{Sn}, \mathrm{Cd}, \mathrm{Ba}, \mathrm{Cr}, \mathrm{Cu}, \mathrm{Pb}$ e Ni) por estes apresentarem a maioria dos resultados abaixo do limite de quantificação ou abaixo do limite de detecção do método. Desta forma, é possível verificar que todos estes elementos apresentaram resultados que atendem aos limites estipulados pela legislação ambiental, uma vez que todos os limites definidos pela legislação ambiental estão abrangidos pelas faixas de trabalho determinadas. 


\section{CONCLUSÃo}

Levando-se em consideração os resultados dos testes estatísticos, bem como a avaliação do comportamento do método pelo analista, foi possível realizar a validação do método analítico para a determinação de metais e semimetais ( $B$, $\mathrm{Sn}, \mathrm{Cd}, \mathrm{Ba}, \mathrm{Cr}, \mathrm{Cu}, \mathrm{Fe}, \mathrm{Mn}, \mathrm{Pb}, \mathrm{Ni}$ e Zn) em efluentes líquidos, por espectrometria de emissão óptica com plasma acoplado indutivamente (ICP-OES). Também foi levado em consideração no processo de validação e estimativa de incerteza do método analítico o preparo das amostras, realizado conforme método EPA 3015A - método de digestão ácida em sistema de microondas.

Avaliando os parâmetros de validação determinados pelo DOQ-CGCRE 008 do INMETRO foi possível concluir que o método é seletivo para todos os elementos avaliados em matriz de efluente, ou seja, não foi observada nenhuma interferência entre analitos ou de outros componentes da matriz. E de acordo com os testes avaliados, as curvas analíticas com e sem matriz são equivalentes, ou seja, as curvas analíticas podem ser construídas somente em meio do solvente que não haverá interferências na quantificação dos elementos.

Todas as curvas analíticas apresentaram linearidade na faixa de trabalho escolhidas, que teve como referência os valores orientativos da legislação Ambiental CONAMA 430/11, Decreto Estadual 8.468/76 e Decreto Estadual 15425/80. O parâmetro linearidade é de extrema importância, pois determina a correlação entre as intensidades observadas e suas respectivas concentrações e impacta diretamente na quantificação dos analitos.

Foram determinados os valores de LDE, LDM e LQM de modo que os resultados obtidos utilizando o método estudado sejam confiáveis, atendam à precisão necessária, além de atenderem à finalidade pretendida, pois todos estes limites estão abaixo dos valores definidos pela legislação ambiental vigente 
(Resolução CONAMA 430/11, DE 8.468/76 e DE15425/80) que determinam os limites para o lançamento de efluente em rede coletora de esgoto e/ou em corpo receptor, além de apresentarem precisão satisfatória.

De acordo com os resultados de precisão e exatidão obtidos avaliando os parâmetros de controle do método (adições em amostras coletadas no decorrer dos anos 2013 e 2014, para avaliação da repetitividade e recuperação do método, duplicatas de amostras coletadas no decorrer dos anos de 2013 e 2014, para avaliação da precisão intermediária, e resultados da participação em programas interlaboratoriais, para avaliação da reprodutibilidade do método analítico) foi possível determinar que o método é adequado para as quantificações desejadas, de modo que todos os resultados obtidos compreendidos na faixa de trabalho estudada apresentam precisão e exatidão satisfatórias, levando em consideração a ordem de grandeza dos resultados e as etapas de preparo e análise das amostras.

Avaliando os resultados do teste de robustez é possível concluir que o método demonstrou ser robusto, uma vez que os parâmetros que apresentaram resultados acima do limite de margem de erro e margem de erro simultânea (qualidade da água e potência do plasma) são parâmetros padronizados no CQMA e também de fácil controle, caso o método seja implantado em outro laboratório de análises.

A partir dos dados do processo de validação e de outras avaliações realizadas, foi possível estimar a incerteza de medição atribuída à quantificação dos onze metais estudados ( $\mathrm{B}, \mathrm{Sn}, \mathrm{Cd}, \mathrm{Ba}, \mathrm{Cr}, \mathrm{Cu}, \mathrm{Fe}, \mathrm{Mn}, \mathrm{Pb}, \mathrm{Ni}$ e Zn) pelo método analítico validado. Foram obtidos resultados de incerteza de medição entre 4,6 e $12,23 \%$ do resultado determinado pela leitura da amostra. A incerteza obtida foi considerada satisfatória uma vez que permite que o método analítico seja devidamente aplicado para sua finalidade que é a determinação de metais e semimetais em efluente líquido, para avaliação do atendimento à legislação ambiental. 
Também foi realizada a estimativa de incerteza de resultados de metais obtidos através da análise de amostras coletadas no decorrer do período de janeiro de 2013 a novembro de 2014, pela metodologia validada. Pela avaliação dos resultados foi possível verificar que, neste período, todos os metais estudados atendem aos limites estabelecidos pela legislação ambiental vigente, mesmo considerando a dispersão dos resultados.

Desta forma concluiu-se que foi possível validar a metodologia analítica estudada, demonstrar que esta é adequada para o fim pretendido (determinação de metais e semimetais em efluentes líquidos por ICP-OES), que apresenta resultados confiáveis e demonstrar que o método se encontra sob controle. Além de determinar a incerteza de medição dos resultados obtidos pelo método estudado, provendo os resultados de uma informação que determina se estes realmente estão atendendo à legislação ambiental ou se ações devem ser tomadas, quanto ao lançamento de metais e semimetais na rede coletora de esgoto e/ou corpo receptor pelo IPEN/CNEN-SP. 


\section{REFERÊNCIAS}

[1] GONÇALVES, J. E. L. As Empresas são grandes coleções de processos. Revista de Administração de Empresas: Organização, Recursos Humanos e Planejamento, v. 40, n. 1, p. 6-19, 2000.

[2] BRASIL. Norma Regulamentadora 25 - Resíduos Industriais. Brasília, DF, 2011: (NR25). Disponível em: <http://portal.mte.gov.br/data/files/8A7C816A31B027B80131B4F9B2F2 5242/nr25.pdf> Acesso em 19 março 2015.

[3] LUNA, A. S., Química analítica ambiental. Rio de Janeiro: Universidade Estadual do Rio de Janeiro, 2003.

[4] BRASIL, Livro de Resoluções CONAMA. Brasília: Ministério do Meio Ambiente, 2015.2 Disponível em: $<\mathrm{http}: / /$ www.mma.gov.br/port/conama/legiano.cfm?codlegitipo=3> Acesso em 11 fevereiro 2015.

[5] ALMEIDA, A. L. M. A. Leis regulamentam o tratamento para emissão de efluentes. Revista Especializada em tratamento de Águas e Efluentes, ed. 2, agosto/ setembro 2011. Disponível em: $<$ http://www.revistatae.com.br/artigos.asp?id=12\&fase=c> Acesso em 14 abril 2015.

[6] BRASIL, O que é o CONAMA?. Brasília: Ministério do Meio Ambiente, 2015. Disponível em: <http://www.mma.gov.br/port/conama/> Acesso em 04 abril 2015.

[7] INSTITUTO BRASILEIRO DO MEIO AMBIENTE E DOS RECUSRSOS NATURAIS RENOVÁVEIS, Acessos à informação > Institucional > Atribuições do IBAMA. 2015. Disponível em: 
$<$ http://www.ibama.gov.br/acesso-a-informacao/atribuicoes> Acesso em 07 maio 2015.

[8] SÃO PAULO, Governo do Estado, Decreto Estadual n 8.468 de 08 de setembro de 1976: Aprova o regulamento da lei $\mathbf{n}^{\circ} 997$ que dispões sobre a prevenção e o controle da poluição do meio ambiente. Disponínel em: http://www.al.sp.gov.br/norma/?id=62153 Acesso em 04 de abril de 2013.

[9] SÃO PAULO, Governo do Estado, Decreto Estadual n० 15.425 de 20 de julho de 1980: Acrescenta dispositivos e procede a alterações, que especifica, ao regulamento da lei $\mathrm{n}^{\circ} 997$, de 1976, aprovado pelo decreto $n^{\circ} 8.468$, de 1976 , que dispõe sobre a prevenção e o controle da poluição do meio ambiente. Disponível em: <http://www.al.sp.gov.br/norma/?id=73483> Acesso em 04 de abril de 2013.

[10] COMPANHIA AMBIENTAL DO ESTADO DE SÃO PAULO. Tecnologia ambiental> Laboratórios> Serviços> Informações Toxicológicas. 2015. Disponível em

http://laboratorios.cetesb.sp.gov.br/servicos/informacoes-toxicologicas/ > Acesso em 12 de fevereiro de 2015.

[11] NORDBERG, G. F., FOWLER, B. A., NORDBERG, M. e FRIBERG, L. T., Handbook on the toxicology of metals. 3 ed. Amsterdam: Elsevier, 2007.

[12] INTITUTO DE PESQUISAS ENERGÉtICAS E NUCLEARES / COMISSÃO NACIONAL DE ENERGIA NUCLEAR. Relatório de avaliação do programa de monitoramento ambiental atendendendo aos compostos químicos estáveis do IPEN (PMA-Q): IPEN/CNEN-SP 
(Relatório interno somente disponível na intranet no instituto). São Paulo, 2011.

[13] BRASIL. Termo de compromisso de ajustamento de conduta (TAC). Ministério do Meio Ambiente (documento somente disponível na intranet do instituto), Distrito Federal, 2011.

[14] CIENFUEGOS F. e VAITSMAN, D. Análise instrumental. Rio de Janeiro: Interciências, 2000.

[15] HOU, X. e JONES, B. T. Inductively coupled plasma/ optical emission Spectrometry. In: MEYERS, R. A. (Ed.) Encyclopedia of analytical chemistry: applications, theory and instrumentation. John Wiley \& Sons: Chichester, 2000. p. 9468-9485.

[16] SkOOG, D. A., HOller, F. J. e NIEMAN, T. A., Principles of instrumental analysis - 5. Ed., Australia: Thomson Learning Academic Resource Center, 1998.

[17] ASSOCIAÇÃO BRASILEIRA DE NORMAS TÉCNICAS. Norma para acreditação de laboratórios. Rio de Janeiro: ABNT, 2005. (ABNT NBR ISO/IEC 17025:2005).

[18] INSTITUTO NACIONAL DE METROLOGIA, QUALIDADE E TECNOLOGIA. Orientação sobre validação de métodos analíticos. INMETRO: Julho de 2011. (DOQ CGCRE 008) Disponível em: $<$ http://www.inmetro.gov.br/Sidoq/Arquivos/Cgcre/DOQ/DOQ-Cgcre8_04.pdf> Acesso em 2013 novembro 2014.

[19] INSTITUTO NACIONAL DE METROLOGIA, QUALIDADE E TECNOLOGIA. Vocabulário internacional de metrologia: conceitos 


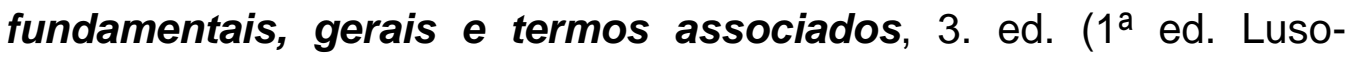
brasileira), Duque de Caxias, RJ: INMETRO, 2012 (VIM 2012).

[20] INSTUTO DE PESQUISAS ENERGÉTICAS E NUCLEARES/ COMISSÃO NACIONAL DE ENERGIA NUCLEAR. Institucional> Sobre - IPEN> Indicadores e Resultados. 2015. Disponível em: $<$ https://www.ipen.br/portal_por/portal/interna.php?secao_id=6> Acesso em 07 maio 2015.

[21] UMBUZEIRO, G. A. Critérios para qualidade da água. Campinas: 2011. Disponível em: $<$ http://www.ilsi.org/Brasi//Documents/Gisela\%20Arag\%C3\%A30\%20Um buzeiro.pdf> Acesso em 12 abril 2015.

[22] COMPANHIA AMBIENTAL DO ESTADO DE SÃO PAULO. Tecnologia ambiental> Laboratórios> Serviços> Informações Toxicológicas> Ficha de Informação Toxicológica - Cádmio. janeiro de 2013. Disponível em: <http://laboratorios.cetesb.sp.gov.br/wpcontent/uploads/sites/47/2013/11/cadmio.pdf> Acesso em 12 outubro 2013.

[23] CARDOSO, L. M. N.; CHASIN, A. A. M. Ecotoxicologia do cádmio e seus compostos. Série Cadernos de Referência Ambiental. vol. 6, Salvador (BA): Centro de Recursos Ambientais, 2001.

[24] AVILA-CAMPOS, M. J. Departamentos> Microbiologia> Linhas de Pesquisa $>$ Mário Júlio Avila-Campos> Temas de Interesse $>$ Metais Pesados> Cádmio (Cd). Universidade de São Paulo, São Paulo: 2015. Disponível em: $<\mathrm{http}: / /$ www.icb.usp.br/bmm/mariojac/index.php?option=com_content\&vi ew=article\&id=42\&ltemid=49\&lang=br> Acesso em 02 maio 2015. 
[25] WORLD HEALTH ORGANIZATION. International Programme on Chemical Safety> Cadmium (EHC 134, 1992). Geneva, 1992. Disponível em: $<$ http://www.inchem.org/documents/ehc/ehc/ehc134.htm> Acesso em: 05 de janeiro de 2015.

[26] AGENCY FOR TOXIC SUBSTANCES \& DISEASE REGISTRY. ATSDR A-Z Index> Cadmium> Toxicological and Health Professionals> Toxicological Profile for Cadmium, Atlanta: U.S. Department of Health and Human Services, 2012.

[27] PAOLIELLO, M. M. e CHASIN, A. A. Ecotoxicologia do chumbo e seus compostos. Série Cadernos de Referência Ambiental. vol. 3., Salvador (BA): Centro de Recursos Ambientais, 2001.

[28] WORLD HEALTH ORGANIZATION. International Programme on Chemical Safety > Inorganic Lead (EHC 165, 1995), 1995. Disponível em: <http://www.inchem.org/documents/ehc/ehc/ehc165.htm> Acesso em: 05 de janeiro de 2015

[29] BURGESS, W. A. Recognition of health hazards in industry: A Review of Materials and Processes. New York: John Wiley \& Sons, 1995.

[30] PANTAROTO, H. L, VIEIRA, M. e FIGUEIREDO, P. J. M. A Eliminação do chumbo da Gasolina. In: Mostra Acadêmica UNIMEP, 5. Ed., 23-25 out., 2007, Piracicaba (SP). Proceedings... Piracicaba: UNIMEP, 2007. Disponível em: $<$ http://www.unimep.br/phpg/mostraacademica/anais/5mostra/5/167.pdf> Acesso em: 12 de dezembro de 2014.

[31] COMPANHIA AMBIENTAL DO ESTADO DE SÃO PAULO. Tecnologia ambiental> Laboratórios> Serviços> Informações Toxicológicas> Ficha de Informação Toxicológica - Chumbo. janeiro de 2013. 
Disponível

em:

<http://www.cetesb.sp.gov.br/userfiles/file/laboratorios/fit/chumbo.pdf> Acesso em 12 outubro 2013.

[32] WORLD HEALTH ORGANIZATION. International Programme on Chemical Safety> Lead: Environmental Aspects (EHC 85, 1989). Geneva, $1989 . \quad$ Disponível em: <http://www.inchem.org/documents/ehc/ehc/ehc85.htm> Acesso em: 13 de janeiro de 2015

[33] MOREIRA, F. R.; MOREIRA, J. C. A Cinética do Chumbo no Organismo Humano e sua Importância para a Saúde. Revista Ciência e Saúde Coletiva, vol. 9, ํㅜ 1, pp. 167 - 181, 2004.

[34] WORLD HEALTH ORGANIZATION. International Programme on Chemical Safety> Copper (EHC 200, 1998), Geneva, 1998, Disponível em: <http://www.inchem.org/documents/ehc/ehc/ehc200.htm> Acesso em: 12 de janeiro de 2015.

[35] PEDROZO, M. D. F. M. e LIMA, I. V. Ecotoxicologia do cobre e seus compostos. Série Cadernos de Referência Ambiental. vol. 2. Salvador (BA): Centro de Recursos Ambientais, 2001.

[36] COMPANHIA AMBIENTAL DO ESTADO DE SÃO PAULO. Tecnologia ambiental> Laboratórios> Serviços> Informações Toxicológicas> Ficha de Informação Toxicológica - Cobre. janeiro 2013. Disponível em: <http://www.cetesb.sp.gov.br/userfiles/file/laboratorios/fit/cobre.pdf> Acesso em 12 outubro 2013.

[37] SILVA, C. S.; PEDROZO, M. D. F. M. Ecotoxicologia de Cromo e seus compostos. Série Cadernos de Referência Ambiental. vol. 05. Salvador (BA): Centro de Recursos Ambientais, 2001. 
[38] MARCOLAN, L., BOUROTTE, C. e BERTOLO, R. Estratificação das concentrações de cromo hexavalente nas águas subterrâneas do Aquífero Adamantina, Município de Urânia, SP, Brasil In: XV Congresso Brasileiro de Águas Subterrâneas, Natal - RN, 11-14 de nov. 2008. Proceedings... Associação Brasileira de Águas Subterrâneas, 2008. Disponível em: $<$ http://aguassubterraneas.abas.org/asubterraneas/article/viewFile/2369 7/15770> Acesso em: 05 de dezembro de 2014.

[39] AGENCY FOR TOXIC SUBSTANCES \& DISEASE REGISTRY. ATSDR A-Z Index> Chomium > Case Studies in Environmental Medicine> Chromium Toxicity, 2008. Disponível em: <http://www.atsdr.cdc.gov/csem/chromium/docs/chromium.pdf> Acesso em 13 de maio de 2014

[40] WORLD HEALTH ORGANIZATION. International Programme on Chemical Safety> Chromium (EHC 61, 1988). Geneva, 1988. Disponível em: <http://www.inchem.org/documents/ehc/ehc/ehc61.htm> Acesso em: 25 de janeiro de 2015

[41] COMPANHIA AMBIENTAL DO ESTADO DE SÃO PAULO. Tecnologia ambiental> Laboratórios> Serviços> Informações Toxicológicas> Ficha de Informação Toxicológica - Zinco. julho 2013. Disponível em: $<$ http://laboratorios.cetesb.sp.gov.br/wpcontent/uploads/sites/47/2013/11/Zinco.pdf> Acesso em outubro 2013.

[42] AGENCY FOR TOXIC SUBSTANCES \& DISEASE REGISTRY. ATSDR A-Z Index> Tin> Toxical and Health Professionals> Toxicological Profile for Tin and Tin Compounds, Atlanta, 2005. Disponível em: $<$ http://www.atsdr.cdc.gov/toxprofiles/tp55.pdf> Acesso em: 13 de maio de 2014. 
[43] COMPANHIA AMBIENTAL DO ESTADO DE SÃO PAULO. Tecnologia ambiental> Laboratórios> Serviços> Informações Toxicológicas> Ficha de Informação Toxicológica - Estanho. novembro 2012. Disponível em: <http://laboratorios.cetesb.sp.gov.br/wpcontent/uploads/sites/47/2013/11/estanho.pdf> Acesso em 12 outubro 2013.

[44] WORLD HEALTH ORGANIZATION. International Programme on Chemical Safety> Tin and Inorganic Tin Compounds, Geneva, 2005. Disponível em: <http://www.who.int/ipcs/publications/cicad/cicad_65_web_version.pdf> Acesso em: 20 de maio de 2014.

[45] AGENCY FOR TOXIC SUBSTANCES \& DISEASE REGISTRY. ATSDR A-Z Index> Nickel> Toxicological and Helath Professionals> Toxical Profile> Toxical Profile for Nickel, Atlanta, 2005. Disponível em: $<$ http://www.atsdr.cdc.gov/toxprofiles/tp15.pdf> Acesso em: 22 de junho de 2015.

[46] COMPANHIA AMBIENTAL DO ESTADO DE SÃO PAULO. Tecnologia ambiental> Laboratórios> Serviços> Informações Toxicológicas> Ficha de Informação Toxicológica - Níquel. janeiro 2012c. Disponível em: $\quad<\quad$ http://laboratorios.cetesb.sp.gov.br/wpcontent/uploads/sites/47/2013/11/niquel.pdf > Acesso em 2012 outubro 2013.

[47] LIMA, I. V. e PEDROZO, M. D. F. M. Ecotoxicologia do Ferro e seus Compostos. Série Cadernos de Referência Ambiental. vol 4. Salvador: Centro de Recursos Ambientais, 2001.

[48] COMPANHIA AMBiental do ESTAdO DE SÃO PAULO. Água> Águas interiores> Informações básicas> Significado ambiental e sanitário das variáveis de qualidade das águas e dos sedimentos e 
metodologias analíticas e de amostragem. julho 2012. Disponível em: $<$ http://cetesb.sp.gov.br/aguas-interiores/wpcontent/uploads/sites/32/2013/11/variaveis.pdf >. Acesso em 132013.

[49] SILVA, D. B.; MONTEIRO, L. R.; FAUSTINO, M. G.; BICUDO, C.; BICUDO, D.; COTRIM, M. E. B. e PIRES, M. A. F. Estudo sobre Ferro e Fósforo nas Águas e Sedimentos da Represa Guarapiranga São Paulo Brasil. In: Simpósio Brasileiro de Recursos Hídricos: Água Desenvolvimento Econômico e Socioeconômico, XX ed., Nov. 17-22, 2013, Bento Gonçalves-RS. Proceedings... São Paulo: IPEN/CNEN-SP, 2013.

Disponível em: http://repositorio.ipen.br/xmlui/handle/123456789/16885> Acessado em: 07 de janeiro de 2014.

[50] AGENCY FOR TOXIC SUBSTANCES \& DISEASE REGISTRY. ATSDR A-Z Index> Barium> Toxicological and Health Professionals> Toxicological Profile> Toxicological Profile for Barium and Barium Compounds. Atlanta, 2007. Disponível em: $<$ http://www.atsdr.cdc.gov/toxprofiles/tp24.pdf> Acesso em: 22 de junho de 2013.

[51] COMPANHIA AMBIENTAL DO ESTADO DE SÃO PAULO. Tecnologia ambiental> Laboratórios> Serviços> Informações Toxicológicas> Ficha de Informação Toxicológica - Bário. janeiro 2012. Disponível em: $\quad<\quad$ http://laboratorios.cetesb.sp.gov.br/wpcontent/uploads/sites/47/2013/11/bario.pdf> Acesso em 12 outubro 2013.

[52] MENDES F. M. e COELHO, N. M. Estudo do Uso da Moringa Oleifera para Remoção de Prata e Manganês em Água. Revista Horizonte Científico. V.1, n. 1, março de 2007. 
[53] MARTINS, I. e LIMA, I. V. Ecotoxicologia do Manganês e seus Compostos. Série Cardernos de Referência Ambiental. vol. 07 Salvador: Centro de Recursos Ambientais, 2001.

[54] AGENCY FOR TOXIC SUBSTANCES \& DISEASE REGISTRY. ATSDR A-Z Index> Manganese> Toxicological and Health Professionals> Toxicological Profile> Toxicological Profile for Manganese, Atlanta, 2012. Disponível em: <http://www.atsdr.cdc.gov/toxprofiles/tp151.pdf> Acesso em: 12 de abril de 2014.

[55] WORLD HEALTH ORGANIZATION. Programmes> W> Water sanitation and health> Emerging issues> Other information that may be of interest> Guidelines for drinking-water quality: chemicals index> M > manganese > Summary statement> Chemical Fact Sheets: Manganese. Geneva, 2012. Disponível em: $<$ http://www.who.int/water_sanitation_health/dwq/chemicals/manganese sum.pdf> Acesso em: 22 de julho de 2014.

[56] AGENCY FOR TOXIC SUBSTANCES \& DISEASE REGISTRY. ATSDR A-Z Index> Boron> Toxicological and Health Professionals> Toxicological Profile> Toxicological Profile for Boron, Atlanta, 2010. Disponível em: <http://www.atsdr.cdc.gov/toxprofiles/tp26.pdf> Acesso em: 23 de janeiro de 2015.

[57] WORLD HEALTH ORGANIZATION. International Programme on Chemical Safety> Boron (EHC 204, 1998), Geneva, 1998. Disponível em: <http://www.inchem.org/documents/ehc/ehc/ehc204.htm> Acesso em 12 de janeiro de 2015.

[58] ASSOCIAÇÃO BRASILEIRA DE NORMAS TÉCNICAS. Critérios para lançamento de efluentes líquidos industriais no sistema coletor 
público de esgoto sanitário - Procedimento, Rio de Janeiro, ABNT, 1987. (NBR 9800)

[59] MACÊDO, J. Introdução à Química Ambiental: Química \& Meio Ambiente \& Sociedade, 2. Ed., Minas Gerais: CRQ-MG, 2006.

[60] BRASIL. Presidência da República. Decreto Federal no 16.300 de 31 de dezembro de 1923. Aprova o regulamento do Departamento Nacional de Saúde Pública. Diário Oficial da União, Brasília, DF, seção 1 de 01 de janeiro de $1924 . \quad$ Disponível em: $<$ http://www2.camara.leg.br/legin/fed/decret/1920-1929/decreto-1630031-dezembro-1923-503177-publicacaooriginal-1-pe.html> Acesso em 07 de abril de 2013

[61] BRASIL. Presidência da República. Constituição da República dos Estados Unidos do Brasil de 16 de julho de 1934. Diário Oficial da União, Brasília, DF, seção 1 - suplemento de 16 de julho de 1934. Disponível em: <http://www2.camara.leg.br/legin/fed/consti/19301939/constituicao-1934-16-julho-1934-365196-publicacaooriginal-1pl.html> Acesso em: 07 de abril de 2013

[62] BRASIL. Presidência da República. Decreto Federal 24.643 de 10 de julho de 1934. Decreta o Código das Águas. Diário Oficial da União, Brasília, DF, seção 1 de 20 de julho de 1934. Disponível em: <http://www2.camara.leg.br/legin/fed/decret/1930-1939/decreto-2464310-julho-1934-498122-publicacaooriginal-1-pe.html> Acesso em 05 de abril de 2013.

[63] BRASIL. Presidência da República. Decreto Lei 2.848 de 07 de dezembro de 1940. Código Penal. Diário Oficial da União. Brasília, DF, seção 1 de 31 de dezembro de 1940 . Disponível em: <http://www2.camara.leg.br/legin/fed/declei/1940-1949/decreto-lei-2848- 
7-dezembro-1940-412868-publicacaooriginal-1-pe.html> Acesso em 05 de abril de 2013.

[64] BRASIL. Presidência da República. Constituição dos Estados Unidos do Brasil de 18 de setembro de 1946, Diário Oficial da União. Brasília, DF, Seção 1 de 19 de setembro de 1946. Disponível em: $<$ http://www2.camara.leg.br/legin/fed/consti/1940-1949/constituicao1946-18-julho-1946-365199-publicacaooriginal-1-pl.html> Acesso em: 15 de abril de 2013.

[65] BRASIL. Presidência da República. Decreto Federal № 49.974-A de 21 de janeiro de 1946. Regulamenta, sob a denominação de Código Nacional de Saúde, a Lei no 2.312, de 3 de setembro de 1954, de normas gerais sobre defesa e proteção da saúde. Diário Oficial da União, Brasília, DF, seção 1 de 28 de janeiro de 1961. Disponível em: $<$ http://www2.camara.leg.br/legin/fed/decret/1960-1969/decreto-49974a-21-janeiro-1961-333333-publicacaooriginal-1-pe.html> Acesso em: 20 de abril de 2013

[66] BRASIL. Presidência da República. Decreto Federal oㅜ 50.877 de 29 de junho de 1961. Dispõe sôbre o lançamento de resíduos tóxicos ou oleosos nas águas interiores ou litorâneas do País, e dá outras providências. Diário Oficial da União. Brasília, DF, seção 1 de 29 de junho de 1961.2 Disponível em: $<$ http://www2.camara.leg.br/legin/fed/decret/1960-1969/decreto-5087729-junho-1961-390520-publicacaooriginal-1-pe.html> Acesso em 12 de março de 2013.

[67] BRASIL. Presidência da República. Lei 4.771 de 15 de setembro de 1965. Institui o Novo Código Florestal. Diário Oficial da União. Brasília, DF, seção 1 de 16 de setembro de 1965. Disponível em: <http://www2.camara.leg.br/legin/fed/lei/1960-1969/lei-4771-15- 
setembro-1965-369026-publicacaooriginal-1-pl.html> Acesso em 12 de março de 2013

[68] BRASIL. Presidência da República. Constituição da República Federativa do Brasil de 25 de janeiro de 1967. Diário Oficial da União. Brasília, DF, seção 1 de 15 de março de 1967. Disponível em: <http://biblio.juridicas.unam.mx/libros/4/1960/10.pdf> Acesso em 12 de março de 2013.

[69] BRASIL. Presidência da República. Decreto-Lei no 303 de 28 de fevereiro de 1967. Cria o Conselho Nacional de Controle da Poluição Ambiental e dá outras providências. Diário Oficial da União. Brasília, DF, seção 1 de 28 de fevereiro de 1967. Disponível em: <http://www2.camara.leg.br/legin/fed/declei/1960-1969/decreto-lei-30328-fevereiro-1967-376059-norma-pe.html> Acesso em: 15 de março de 2013.

[70] BRASIL. Presidência da República. Decreto № 73.030 de 30 de outubro de 1973. Cria, no âmbito do Ministério do Interior, a Secretaria Especial do Meio Ambiente - SEMA, e da outras providências. Diário Oficial da União. Brasília, DF, seção 1 de 30 de outubro de 1973. Disponível em: <http://www2.camara.leg.br/legin/fed/decret/1970-1979/decreto-7303030-outubro-1973-421650-publicacaooriginal-1-pe.html> Acesso em: 15 de março de 2013.

[71] BRASIL. Presidência da República, Decreto Lei 1.413 de 14 de agosto de 1975. Dispões sobre o controle da poluição do Meio Ambiente provocada por atividades industrais. Diário Oficial da União. Brasília, DF, seção 1 de 14 de agosto de 1975. Disponível em: <http://www2.camara.leg.br/legin/fed/declei/1970-1979/decreto-lei-141314-agosto-1975-378171-publicacaooriginal-1-pe.html> Acesso em: 20 de março de 2013. 
[72] BRASIL. Ministério do Interior (Minter). Portaria Minter n013: Estabelece a classificação de águas interiores. 1976.

[73] BRASIL. Ministério do Interior (Minter). Portaria Minter $n^{\circ} 0536$ : Estabelece padrões de água para fins de balneabilidade e recreação. 1976.

[74] BRASIL. Presidência da República. Decreto Federal ㄲo 81.107 de 22 de dezembro de 1977. Define o elenco de atividades consideradas de alto interesse para o desenvolvimento e a segurança nacional. Diário Oficial da União. Brasília, DF, seção 1 de 23 de dezembro de 1977. Disponível em:

<http://legis.senado.gov.br/legislacao/ListaPublicacoes.action?id=20987 0\&tipoDocumento=DEC\&tipoTexto=PUB $>$ Acesso em: 12 de março de 2013.

[75] BRASIL. Presidência da República. Portaria Interministerial no 01 de 23 de janeiro de 1978. Faz recomendação quanto à classificação e o enquadramento de águas federais e estaduais, para efeito de controle da poluição.

Disponível em: $<$ http://www.ipef.br/legislacao/bdlegislacao/detalhes.asp?ld=234> Acesso em: 25 de março em 2013.

[76] BRASIL. Presidência da República. Portaria Interministerial № 90 de 29 de março de 1978. Cria o Comitê Especial de Estudos Integrados de Bacias Hidrográficas - CEEIBH. 1978.

[77] BRASIL. Presidência da República. Lei 6.803 de 2 de julho de 1980. Dispões sobre as diretrizes básicas para o zoneamento industrial nas áreas críticas de poluição, e dá outras providências. Diário Oficial da União. Brasília, DF, seção 1, 3 de julho de 1980. Disponível em: <http://www2.camara.leg.br/legin/fed/lei/1980-1987/lei-6803-2-julho- 
1980-366117-publicacaooriginal-1-pl.html> Acesso em: 25 de março de 2013.

[78] BRASIL. Presidência da República. Lei 6.938 de 31 de agosto de 1981. Dispõe sobre a Política Nacional do Meio Ambiente, seus fins e mecanismos de formulação e aplicação, e dá outras providências. Diário Oficial da União. Basília, DF, seção 1, 02 de setembro de 1981. Disponível em: $<$ http://www.mma.gov.br/port/conama/legiabre.cfm?codlegi=313> Acesso em: 19 de março de 2013.

[79] BRASIL. Presidência da República. Decreto Federal o 88.351 de 01 de julho de 1983. Regulamenta a Lei $n^{\circ} 6.938$, de 31 de agosto de 1981, e a Lei $n^{\circ}$ 6.902, de 27 de abril de 1981, que dispõem, respectivamente, sobre a Política Nacional do Meio Ambiente e sobre a criação de Estações Ecológicas e Áreas de Proteção. Diário Oficial da União. Brasília, DF, seção 1, 3 de junho de 1983. Disponível em: $<$ http://www2.camara.leg.br/legin/fed/decret/1980-1987/decreto-883511-junho-1983-438446-publicacaooriginal-1-pe.html> Acesso em 23 de março de 2013.

[80] BRASIL. Presidência da República. Constituição da República Federativa do Brasil de 5 de outubro de 1988. Diário Oficial da União. Brasília, DF, seção 1,5 de outubro de 1988. Disponível em: <http://www.planalto.gov.br/ccivil_03/Constituicao/Constituicao.htm> Acesso em: 23 de março de 2013

[81] BRASIL. Presidência da República. Lei Federal 7.797 de 10 de julho de 1989. Cria o Fundo Nacional de Meio Ambiente e dá outras providências. Diário Oficial da União. Brasília, DF, seção 1 de 11 de julho de 1989. Disponível em: <http://www.planalto.gov.br/ccivil_03/leis/L7797.htm> Acesso em: 29 de março de 2013. 
[82] BRASIL. Presidência da República. Lei Federal 9.433 de 8 de janeiro de 1997. Institui a Política Nacional de Recursos Hídricos e cria o Sistema Nacional de Gerenciamento de Recursos Hidricos. Diário Oficial da União. Brasília, DF, seção 1 de 09 de janeiro de 1997. Disponível em: <http://www.planalto.gov.br/ccivil_03/LEIS/L9433.htm> Acesso em: 17 de abril de 2013

[83] BRASIL. Presidência da República. Lei Federal de Crimes Ambientais 9.605. de 12 de fevereiro de 1998. Dispões sobre as sanções penais e administrativas derivadas de condutas e atividades. Diário Oficial da União. Brasília, DF. Seção 1, 13 de fevereiro de 1998. Disponível em: $<$ http://www.planalto.gov.br/ccivil_03/LEIS/L9605.htm> Acesso em: 17 de abril de 2013.

[84] BRASIL. Presidência da República. Lei Federal 9.984 de 17 de julho de 2000. Dispões sobre a criação da Agência Nacional de Águas, entidade federal de implementação da PNRH e de coordenação do SNGRH, e dá outras providências. Diário Oficial da União. Brasília, DF. Seção 1, 18 de julho de 2000.2 Disponível em: <http://www2.camara.leg.br/legin/fed/lei/2000/lei-9984-17-julho-2000360468-publicacaooriginal-1-pl.html> Acesso em: 15 de março de 2013.

[85] BRASIL. Agência Nacional de Águas - ANA. Acesso à informação ANA> Institucional> Sobre a ANA. 2015. Disponível em: $<$ http://www2.ana.gov.br/Paginas/institucional/SobreaAna/Default.aspx> Acesso em 07 abril 2015.

[86] BRASIL. Agência Nacional de Águas - ANA. Resolução ANA $n^{\circ}$ 219: Diretrizes para análise e emissão de outorga de direito de uso de recursos hídricos para fins de lançamento de efluentes. 2005. Dsponível em: <http://arquivos.ana.gov.br/resolucoes/2005/219-2005.pdf> Acesso em: 24 de abril de 2013. 
[87] BRASIL. Presidência da República. Lei Federal 11.445 de 5 de janeiro de 2007. Estabelece diretrizes nacionais para o saneamento básico. Diário Oficial da União. Brasília, DF, seção 1, 8 de janeiro de 2007. Disponível

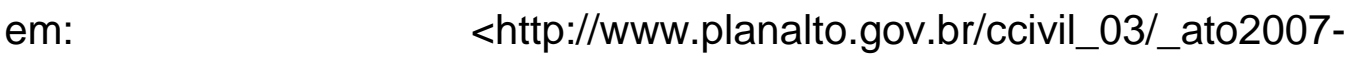
2010/2007/lei//11445.htm> Acesso em: 10 de abril de 2013.

[88] BRASIL. Rede das Águas. SOS Mata Atlântica> Plíticas Públicas> Uma Política Pública para as Águas. 2013. Disponível em: $<$ http://www.rededasaguas.org.br/politicas-publicas/inicio-politicaspublicas/> Acesso em 27 Setembro 2013.

[89] ORGANIZAÇÃO DAS NAÇÕES UNIDAS. Especiais> A ONU em ação> Águas A ONU e a Água. ONUBR, 2014. Disponível em: <http://nacoesunidas.org/acao/agua/> Acesso em 25 maio 2015.

[90] LUCHINI, A. D. M.; SOUZA, M. D. D. e PINTO, A. L. Aportes e Limites da Perspectiva de Redes de Políticas Públicas: O Caso da Gestão da Água. Caderno de Pesquisas em Administração, v. 10, n.2, p.87-94, abril/junho 2003.

[91] IORIS, A. Desenvolvimento Nacional e Gestão de Recursos Hídricos no Brasil. Revista Crítica de Ciências Sociais, vol. 85, p. 23-41, 2009.

[92] VENDRUSCOLO, S. Interfaces entre a Política Nacional de Recursos Hídricos e a Política Nacional de Defesa Civil, com relação aos Desastres Hidrológicos. 2007. p. 143. Dissertação (Mestrado em Engenharia Ambiental) - Universidade Federal de Santa Catarina, Florianópolis. Disponível em: $<$ https://repositorio.ufsc.br/xmlui/bitstream/handle/123456789/90198/243 838. pdf?sequence $=1$ \&isAllowed $=y>$ Acesso em: 12 de setembro de 2013. 
[93] NEVES, M. J. Planos de Recursos Hídricos: do Planejamento Racional ao Planejamento Político. In: Simpósio de Recursos Hídricos do Nordeste, X. ed., Nov. 16-19, 2010 (Apresentação de Trabalho). Disponível em: $<$ http://www.acquacon.com.br/xsrhn/palestras/marcojosemelonevesmma.pdf>. Acesso em 15 outubro 2013.

[94] SANTOS, I. A. D. e SAITO, C. H. A mitificação da participação social na Política Nacional de Recursos Hídricos - Gêneses, Motivação e Inclusão Social. Geosul. Revista Geosul, v. 21, n. 42, p. 7-27. Jul/ dez. 2006.

[95] BRASIL. SOS Mata Atlântica> Projetos> Rede das Águas> Sociedade Civil> O Papel da Sociedade Civil na Política de Recursos Hídricos. 2001. Disponível em: http://www.rededasaguas.or.br/sociedade-civil/. Acesso em 05 Dezembro 2013.

[96] UMBUZEIRO, G. A. Guia de Potabilidade para substâncias Químicas, São Paulo: Limiar, 2012. Disponível em: <http://www.abas.org/arquivos/guiapotabilidade.pdf> Acesso em 22 de julho de 2012.

[97] MONTEIRO, L. R.; GONÇALVES, C.; MEDALLA, F. Q.; COTRIM, M. E. B. e PIRES, M. A. F. Preliminary Chemical Quality Evaluation of IPEN's Groundwaterfor Stable Elements. In: International Nuclear Atlantic Conference. Belo Horizonte-MG, Out. 24-28, 2011. Disponível em: <https://www.ipen.br/biblioteca/2011/inac/16990> Acesso em: 12 de janeiro de 2013

[98] BRASIL. Presidência da República. Lei 9.433 de 8 de janeiro de 1997. Política Nacional de Recursos Hídricos. Diário Oficial da União. Brasília, DF. Seção 1, 09 de janeiro de 1997. Disponível em: 
<http://www.planalto.gov.br/civil_03/LEIS/19433.htm> Acesso em 27 Setembro 2013.

[99] BRASIL. Ministério do Meio Ambiente. Colegiados> CONAMA> CONAMA: Conselho Nacional do Meio Ambiente. 2013. [Disponível em: <http://www.mma.gov.br/port/conama/> Acesso em 27 setembro 2013.

[100] ATKINS, P. e JONES, L. Princípios de Química: Questionando a Vida Moderna e o Meio Ambiente. 3aㅗ ed., Bookman, 2006.

[101] HARRIS, D. C. Explorando a Química Analítica. Rio de Janeiro: LTC, 2011.

[102] HARRIS, D. C. Análise Química Quantitativa. Rio de Janeiro: LTC, 2005

[103] OLESIK, J. W. Elemental analysis using an evaluation and assessment of remaining problems. Analytical Chemistry. vol. 63, 1 ed, p. 12A-21A, 1991.

[104] EWING, G. W. Instrumental Methods of Chemical Analysis. 5th ed. Singapore: McGraw-Hill Book Co. 1985.

[105] UNIVERSIDADE FEDERAL DO CEARÁ. Processo de Absorção e Emissão de Fótons. Universidade Federal do Ceará, 2014. Disponível em: <http://www.seara.ufc.br/especiais/fisica/lasers/laser2.htm>. Acesso em 04 maio 2014.

[106] WINGE, R. K.; FASSEL, V. A.; PETERSON, V. J. e FLOYD, M. A. Inductively Coupled Plasma - Atomic Emission Spectroscopy: An Atlas of Spectral Information. Elsevier, 1989. 
[107] KUMAR, S. Inductively Coupled Plasma Optical Emission Spectrometer 13 junho 2013. Disponível em: <http://analyticalprofessional.blogspot.com.br/2013/06/inductivecoupled-plasma-optical.html> Acesso em 04 maio 2014.

[108] INTERNATIONAL UNION OF PURE AND APPLIED CHEMISTRY. Compendium of Chemical Terminology (The Gold Book), 2nd ed., Oxford: Blackwell Scientific Publications, 2006. Disponível em: <http://goldbook.iupac.org/> Acesso em 23 de março de 2014.

[109] HIRATA. Y. S. Apostila de Teinamento de Validação de Métodos Analíticos. Curso Validação de Métodos de Ensaios Analíticos Rede Metrológica de São Paulo. 2013 (Material didático apresentado no curso Validação de Métodos de Ensaios Analíticos)

[110] INSTITUTO NACIONAL DE METROLOGIA, QUALIDADE E TECNOLOGIA. Critérios para Acreditação da Amostragem de Águas e Matrizes Ambientais. Rio de Janiro, INMETRO: 2010 (NIT DICLA 057).

[111] HEYDEN, Y. V.; NIJHUIS, A.; SMEYERS-VERBEKE, J.; VANDEGINSTEN, B. G. M.; MASSART, D. L. Guidance for robustness/ ruggedness tests in method validation. Journal of Pharmatical and Biomedical Analysis, vol. 24, p. 723 - 753, 2001.

[112] INSTITUTO NACIONAL DE METROLOGIA, QUALIDADE E TECNOLOGIA. Avaliação de dados de medição: Guia para expressão de Incerteza de medição - GUM, Duque de Caxias: INMETRO/CICMA/SEPIN, 2008, p. 141.

[113] COMPANHIA AMBIENTAL DO ESTADO DE SÃO PAULO. Guia Nacional de Coleta e Preservação de Amostras: água, sedimento, comunidades aquáticas e efluentes líquidos. 2011. Disponível em: 
$<$ http://www.cetesb.sp.gov.br/userfiles/file/laboratorios/publicacoes/guianacional-coleta-2012.pdf> Acesso em 25 agosto 2014.

[114] AMERICAN PUBLIC HEALTH ASSOCIATION; AMERICAN WATER WORKS ASSOCIATION; WATER ENVIRONMENT FEDERATION, Standard Methods for the Examination of Water and Wastewater, 2005 (APHA AWWA WPCF).

[115] ENVIRONMENTAL PROTECTION AGENCY. Microwave Assisted Acid Digestion of Aqueous Samples and Extracts, 2007(EPA 3015A).

[116] FURUSAWA, H. A. Planilha de Validação de Métodos Analíticos, São Paulo: IPEN/ CNEN-SP, 2012.

[117] KONIECZKA, P.;NAMIESNIK, J. Quality Assurance and Quality Control in the Analytical Chemical Laboratory: A Practical Approach, CRC Press, 2009.

[118] COUTINHO, E. S. F.; CUNHA, G. M. Conceitos Básicos de Epidemiologia e Estatística para Leitura de Ensaios Clínicos Controlados. Revista Brasileira de Psiquiatria. vol. 27, oㅡ 2, p. 146 - 151, 2005.

[119] CHEN, M. e MA, L. Q. Comparison of Four USEPA Digestion Methods for Trace Metals analysis Using Certified and Florida Soils. Journal of Environmental Quality. vol. 27, № 6, p. 1294 - 1300, 1998.

REDE METROLÓGICA DO RIO GRANDE DO SUL. Relatório do [120] Programa Interlaboratorial da Rede Metrológica do Rio Grando do Sul. São Paulo, 2014. 
[121] INSTITUTO NACIONAL DE METROLOGIA, QUALIDADE E TECNOLOGIA. Orientação sobre validação de métodos analíticos. INMETRO: Março de 2003. (DOQ CGCRE 008)

[122] PRODUKTGRUPPE SPECTROFLAME - ICP. Spektrallinien fur ICPOE-Spektrometer. SPECTROFLAME: 9 de fevereiro de 1999. (Guia de linhas espectrais para o espectrômetro ICP).

[123] KOCOUREK, V. Institute of Chemical Trchnology of Prague Method Validation and Quality Control Procedures. Department of Food Chemistry and Analysis (ICT) 2012. Disponível em: <http://web.vscht.cz/ kocourev/en_GB/files/Method\%20validation\%2020 12.pdf> Acesso em 14 abril 2015.CHEN, M. e MA, L. Q. Comparison of Four USEPA Digestion Methods for Trace Metals analysis Using Certified and Florida Soils. Journal of Environmental Quality. vol. 27, nำ6, p. 1294 - 1300, 1998.

[124] SHIHOMATSU, H. M. Desenvolvimento de Validação de Metodologia SPE-LC-MS/MS para a Determinação de Fármacos e Droga de Abuso nas Águas da Represa Guarapiranga-São Paulo/SP, Brasil. 2015. p. 224. (Doutorado em Tecnologia Nuclear) - Instituto de Pesquisas Energéticas e Nucleares - IPEN-CNEN/SP, São Paulo. Disponível em: < http://www.teses.usp.br/teses/disponiveis/85/85134/tde-28042015095207/pt-br.php> Acesso em: 02 de junho de 2015. 